\title{
Implementation and Commercialization of New Plant Germplasms for Use on Military Ranges
}

\section{US Army Corps of Engineers ${ }_{\circledast}$}

Engineer Research and Development Center

Antonio J. Palazzo, Susan E. Hardy, Timothy J. Cary,

December 2009

Kevin Jensen, Blair Waldron, and Steve Larson

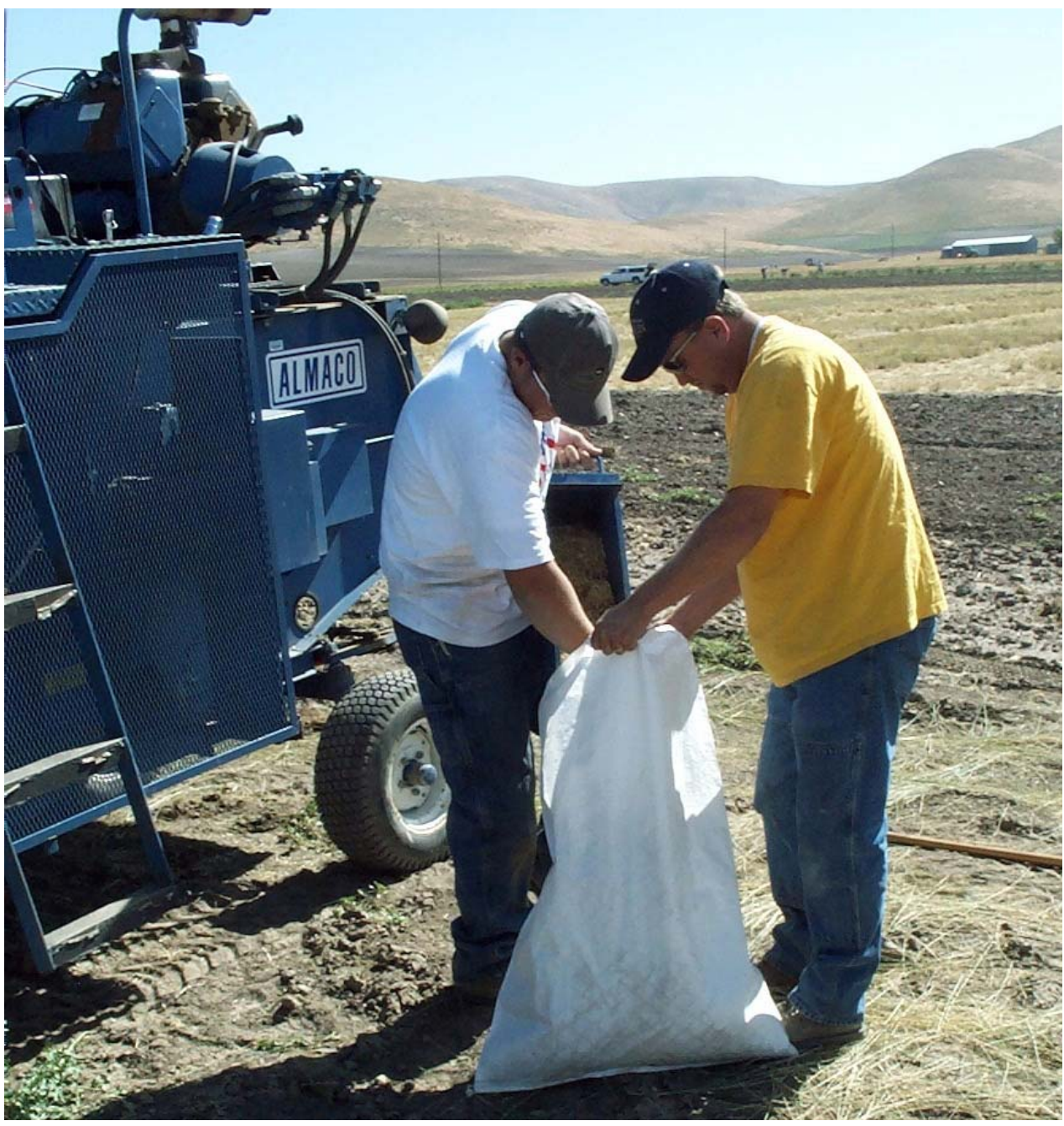





\section{Implementation and Commercialization of New Plant Germplasms for Use on Military Ranges}

Antonio J. Palazzo, Susan E. Hardy, and Timothy J. Cary

Cold Regions Research and Engineering Laboratory

72 Lyme Road

Hanover, New Hampshire 03755-1290

Kevin Jensen, Blair Waldron, and Steve Larson

United States Department of Agriculture

Agricultural Research Service

Logan, Utah 84322-6300

Final report

Approved for public release; distribution is unlimited.

Prepared for Environmental Security Technology Certification Program

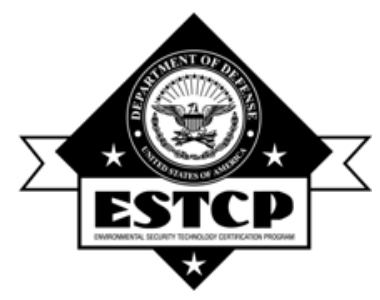

Under ESTCP Project SI-0401 


\begin{abstract}
Our objectives were to demonstrate and make available new plant germplasms that are more beneficial for military training lands and to develop methods to better establish native plants that are competitive with invasive introduced plants. Under Strategic Environmental Research and Development Program (SERDP) project SI-1103, we developed germplasms that establish readily, stand up to wear from military vehicles, and compete well with invasive plants but are not themselves invasive. Validation and release of the new germplasms were accomplished under both the SERDP and Environmental Security Technology Certification Program (ESTCP) programs; under ESTCP we also initiated seed contracts and prepared a planting guide (Palazzo et al. 2009). Our ten releases (including six cultivars) are summarized in notices published in Crop Science or the J ournal of Plant Registrations. One additional release is expected in the next year or two. Three germplasms were put into production, and the seed was made available for two years to land managers at eight Department of Defense (DoD) facilities. A commercial sale of 'FirstStrike' slender wheatgrass has been completed. We also developed seeding methods that have proven successful on eastern and western ranges to establish viable native plant stands quickly and compete with invasive plant establishment.
\end{abstract}

DISCLAIMER: The contents of this report are not to be used for advertising, publication, or promotional purposes. Citation of trade names does not constitute an official endorsement or approval of the use of such commercial products. All product names and trademarks cited are the property of their respective owners. The findings of this report are not to be construed as an official Department of the Army position unless so designated by other authorized documents. 


\section{Contents}

Figures and Tables....................................................................................................................

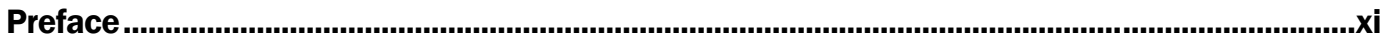

Terminology …........................................................................................................................... xii

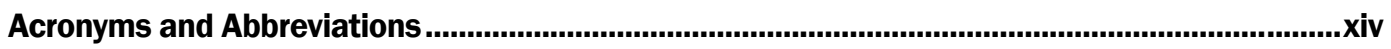

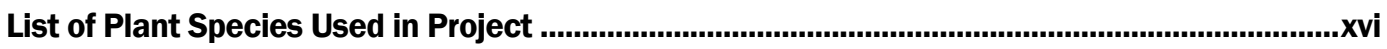

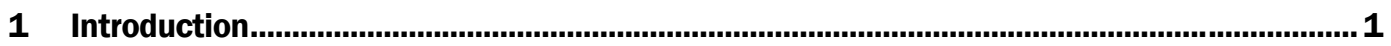

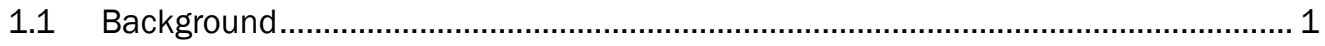

1.2 Objectives of the demonstration .................................................................... 3

1.3 Regulatory drivers.................................................................................... 4

2 Technology

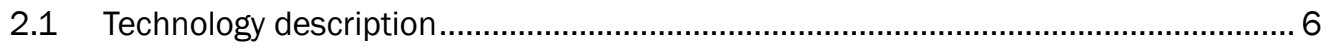

2.2 Technology development............................................................................... 10

2.2.1 Breeding resilient plants................................................................................. 10

2.2.2 Developing the ecological-bridge concept...................................................... 14

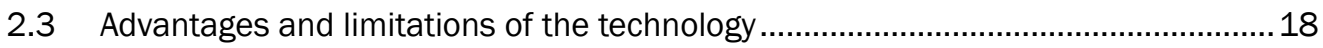

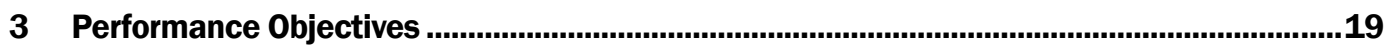

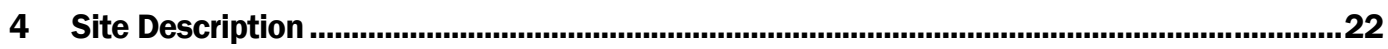

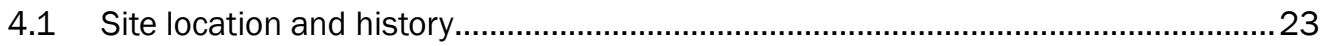

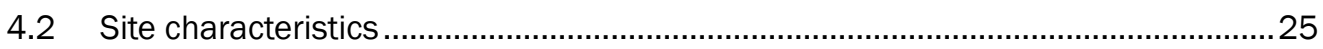

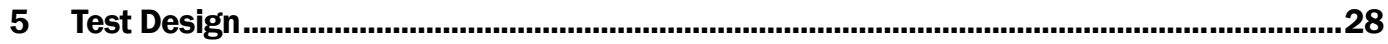

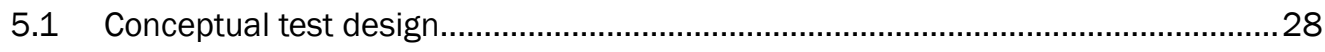

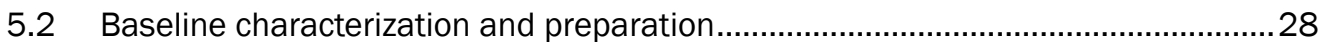

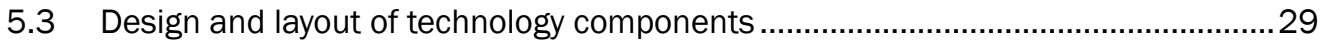

5.3.1 Field evaluations of new germplasms: comparisons of germplasms with

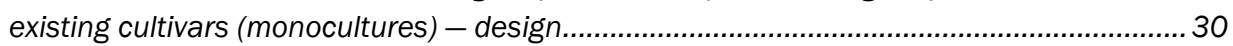

5.3.2 Ecological-bridge demonstration (mixtures) - design ........................................ 32

5.3.3 Military traffic on monocultures at Yakima Training Center - design ................... 36

5.3.4 Cultivar validation: germination and nursery-field studies - design.....................37

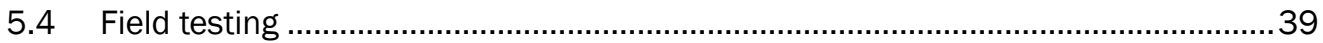

5.4.1 Field evaluations of new germplasms: comparisons of germplasms with existing cultivars (monocultures) - testing ..................................................................... 41

5.4.2 Ecological-bridge demonstration (mixtures) - testing......................................... 41

5.4.3 Military traffic on monocultures at YTC - testing.............................................. 42

5.4.4 Cultivar validation: Germination and nursery-field studies - testing.................... 44

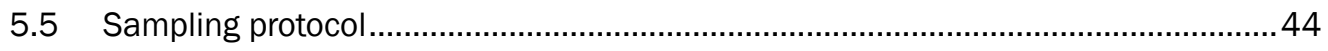




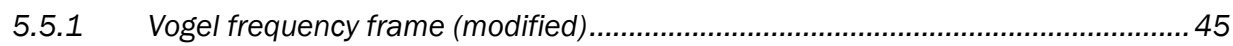

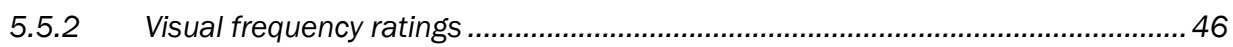

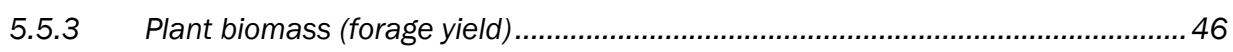

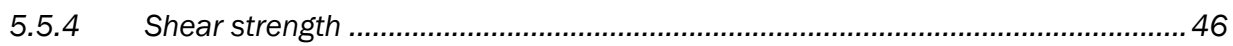

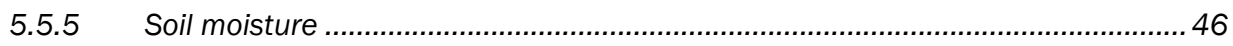

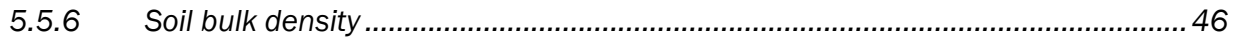

5.5.7 Soil compaction (penetration resistance) ...........................................................46

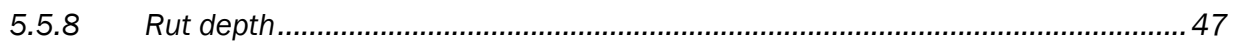

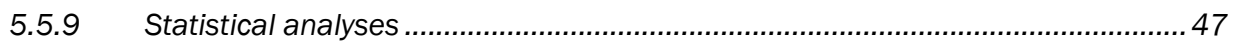

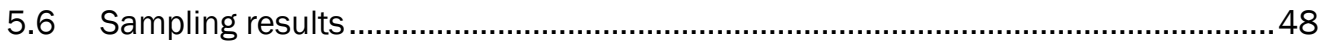

5.6.1 Field evaluations of new germplasms: comparisons of germplasms with existing cultivars (monocultures) - results ....................................................................... 48

5.6.2 Ecological-bridge demonstration (mixtures) - results......................................... 54

5.6.3 Military traffic on monocultures at YTC - results..................................................59

5.6.4 Cultivar validation: germination and nursery-field studies - results .................... 63

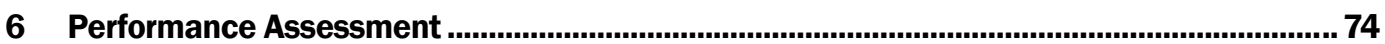

6.1 Improved establishment of modified germplasms .............................................. 74

6.2 Release of new germplasms ...................................................................... 75

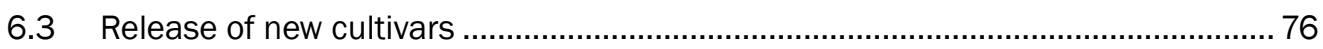

6.4 Improved resilience of modified germplasms to military traffic ..............................77

6.5 Improved establishment of native grass stands ............................................... 77

6.6 Reduction of noxious weeds on training lands ............................................. 78

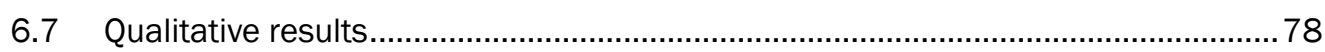

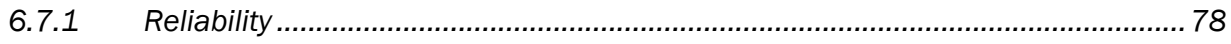

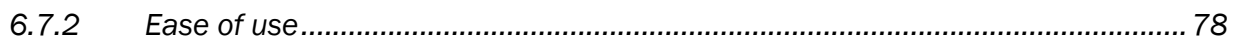

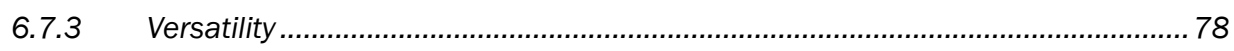

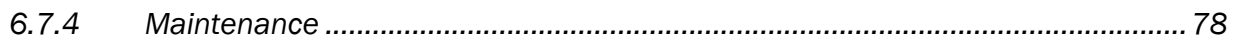

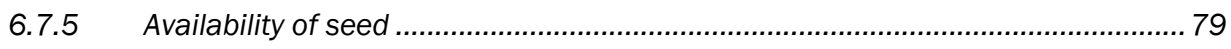

6.7.6 Awareness of seed capabilities and planting methods ...................................... 79

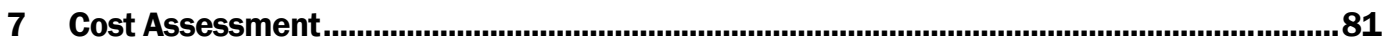

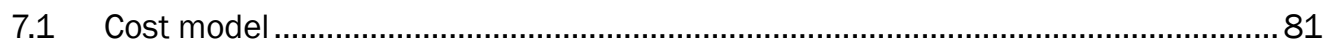

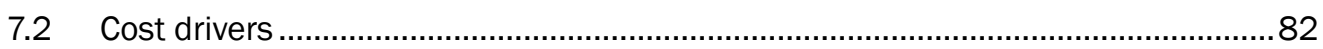

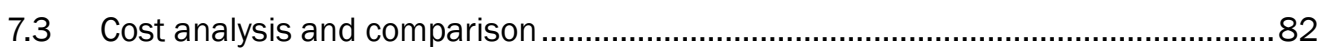

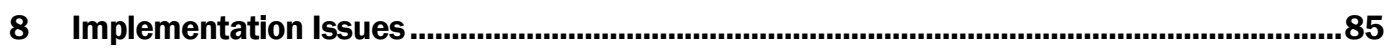

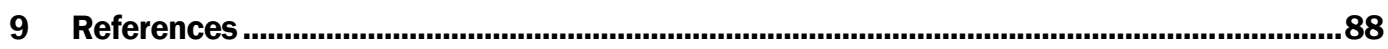

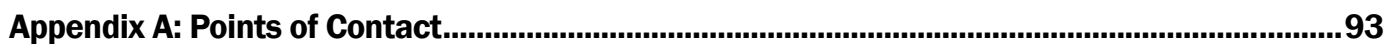

\section{Appendix B: Decision Paper on Public Releases for the Germplasms Developed under} the SERDP and ESTCP Programs ........................................................................................94

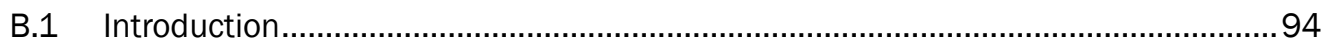

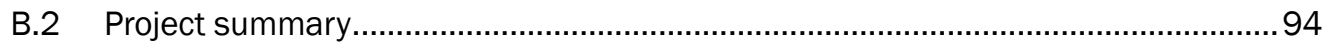

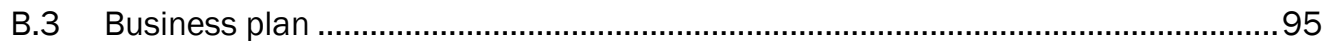

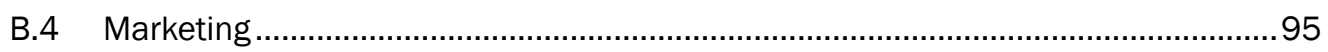




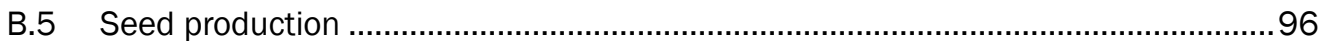

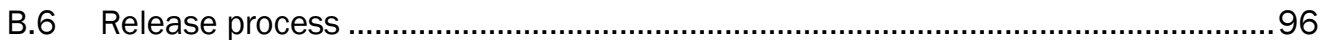

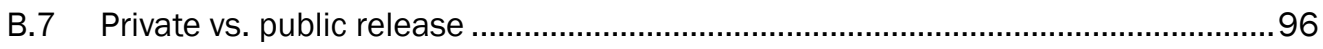

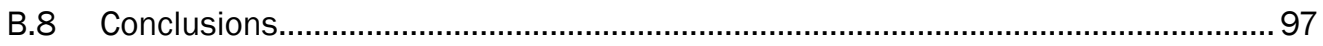

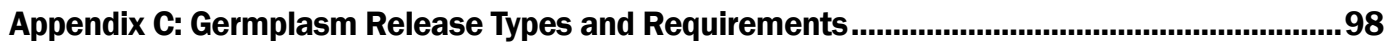

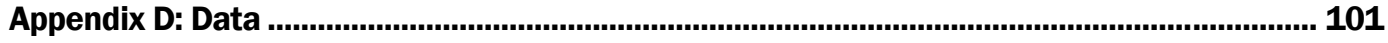

D.1 Results of preliminary evaluation trials to identify promising species

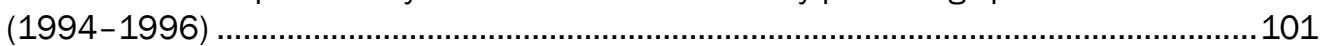

D.2 Yakima Training Center seeding list (monocultures and mixtures) ........................105

D.3 Camp Guernsey seeding lists (monocultures and mixtures) .................................107

D.4 Dugway Proving Ground seeding list (monocultures) .........................................110

D.5 Yakima Training Center data (monocultures and mixtures)..................................118

D.6 Camp Guernsey data (monocultures and mixtures)...........................................128

D.7 Fort Drum data (mixtures) .........................................................................145

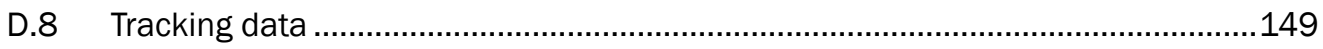

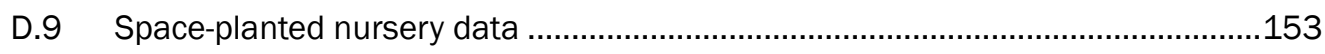

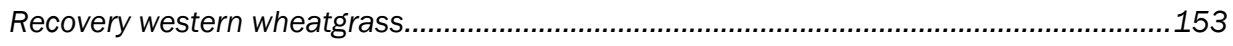

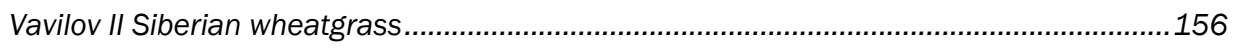

Bozoisky II Russian wildrye.....................................................................................157

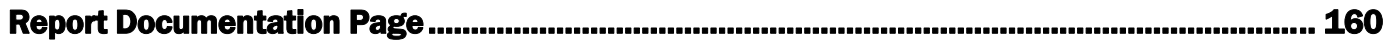




\section{Figures and Tables}

\section{Figures}

Figure 1. Plant-breeding cycle.

Figure 2. A conceptual model on how an introduced nurse-crop species acts as an "ecological bridge" on sandy soils at Fort Drum, allowing fescues and eventually the desired native grass, switchgrass, to become established.

Figure 3. Percent annual and biennial weeds in Turkey Creek plots planted with the standard Fort Carson mix or with a core native mix plus an introduced grass (as named on the treatment axis).

Figure 4. Percent native grasses in Turkey Creek plots planted with the standard Fort Carson mix or with a core native mix plus an introduced grass (as named on the treatment axis).

Figure 5. Switchgrass dominating an ecological-bridge plot at Fort Drum, 4 years after seeding.

Figure 6. The general range of distribution for SERDP-select germplasms, showing locations of the main demonstration sites and other military facilities in the Intermountain West as they existed at the beginning of this study.

Figure 7. Arrangement of plots at the Fort Drum Airport site. $W L=$ weeping lovegrass, $H G$

$=$ hairgrass, $\mathrm{SG}=$ switchgrass, $\mathrm{FF}=$ fine fescues (sheep and hard fescue).

Figure 8. Arrangement of plots at the Fort Drum Area 8 site; the numbers represent the same mixtures as for the Airport site (Figure 7 and Table 7).

Figure 9. Traffic design at YTC Exit 11 (Note: Plot 1, Rep 1 is in the lower right corner; plot numbers go from the bottom up).

Figure 10. Location of sampling points before and after tracking; green represents planted rows, which are perpendicular to the tracking ruts.

Figure 11. Pin profilometer used in a 4-pass rut immediately after tracking in June 2005.

Figure 12. Percent establishment of modified germplasms (green) vs. standard cultivars at Exit 11 YTC in May 2003, 6 months after seeding.

Figure 13. Percent stand vegetation from 2003 to 2005 (before June 2005 tracking at YTC)

Figure 14. Airport site percent cover on the four plots seeded with switchgrass (see Table 7 for seeding mixtures)

Figure 15. Mean soil compaction results in ruts immediately after June 2005 tracking at YTC (the deeper the penetrometer depth, the less compact the soil).

Figure 16. Percentage stand for vegetation immediately after and 1 year following 2005 tracking at YTC (Figure 13 shows percentage stand for 2003-2005 before tracking)..

Figure 17. Stand of Recovery western wheatgrass as compared to standard western wheatgrass checks when evaluated at eight locations throughout the western United States Error bars are the LSD value at the $\mathrm{P}=0.05$ probability level. The " $4+\mathrm{Yr}$ " category is the latest evaluation taken at a given site and ranges from 4-6 years after planting. (Waldron et al. in press). 
Figure 18. Seedling establishment for Vavilov II Siberian wheatgrass at five sites (Jensen et al. 2009).

Figure 19. Persistence for Vavilov II Siberian wheatgrass at five sites (Jensen et al. 2009)

\section{Tables}

Table 1. Modified traits and current status of SERDP-select germplasms; (bold type

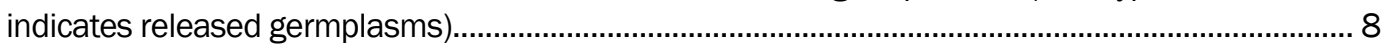

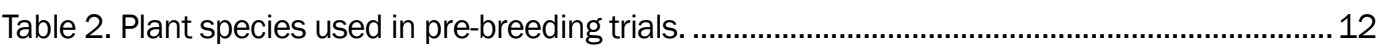

Table 3. Percentage of cheatgrass in establishment-study plots at Yakima Training Center in 2000 ( 2 years after establishment)................................................................................... 15

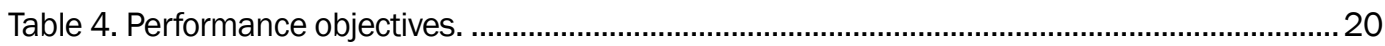

Table 5. Seed mixtures planted at both YTC (Exit 11 sown in October 2002) and Camp Guernsey (River site, March 2004; Tower site, March 2005)........................................................32

Table 6. Additional mixtures sown at Camp Guernsey in March 2004 (River site) and March 2005 (Tower site) ..................................................................................................................

Table 7. Mixtures seeded at two Fort Drum sites (22 May 2002).................................................. 34

Table 8. Locations of space-planted nursery-field trials for cultivar validation ...................................38

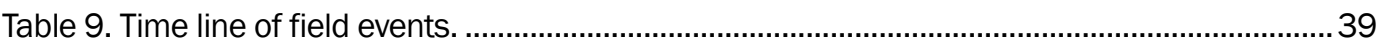

Table 10. Soil and vegetation measurements before and after traffic event (June 2005),

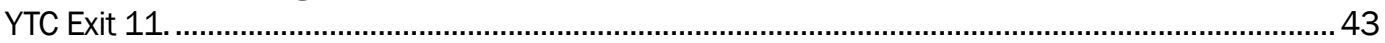

Table 11. Summary of vegetation sampling protocol at each site. ................................................ 45

Table 12. Establishment and persistence of monocultures for 3 years at YTC Exit 11 (seeded 21-22 October 2002).

Table 13. Camp Guernsey site establishment data at two sites taken 2 months after seeding (River site seeded 31 March 2004, data taken 2 June 2004; Tower site seeded 23 March 2005, data taken 2 June 2005).

Table 14. Camp Guernsey site persistence data at two sites taken 1 year after seeding (River site seeded 31 March 2004, data taken 2 June 2005; Radar site seeded 23 March 2005, data taken 19 July 2006).

Table 15. Camp Guernsey River site persistence data 2 years after seeding (seeded 31 March 2004; data taken 19 July 2006).

Table 16. Dugway Proving Ground establishment data 6 months after seeding (seeded 7 November 2005; data taken 10 May 2006). .54

Table 17. YTC mixtures approximately 6 months, 1.5 years, and 2.5 years after seeding.

Table 18. Camp Guernsey River site mixtures 2 months and 1 and 2 years after seeding (seeded 31 March 2004).

Table 19. Camp Guernsey Tower site mixtures 2 months and 1 year after seeding (seeded 23 March 2005). 57

Table 20. Fort Drum Area 8: 1-year site percent cover and bare ground on 24 June 2003.............58

Table 21. Overall soil properties over 3 years after tracking in June 2005......................................60

Table 22. Summary data for tracking and annual effects on plant cover at YTC. 61

Table 23. Summary of plant cover for each entry at YTC over all treatments for 3 years after tracking (2005-2007). 
Table 24. Varieties showing significant differences at the different tracking passes over 3 years of data (2005-2007) after tracking at YTC.

Table 25. Temperature effects on all entries combined in germination growth pouch studies.

Table 26. Species comparisons of average days to germination in growth pouch studies.

Table 27. Species comparisons of average percent germination in growth pouch studies.

Table 28. Overall comparisons with all temperatures combined in germination growth pouch studies.

Table 29. Stand establishment and persistence over 1 year at two Fillmore, Utah sites, established fall 2003 (Site 1) and 2004 (Site 2) (Jensen et al. 2007).

Table 30. Stand establishment at Malta, Idaho site, established fall 2004 (Jensen et al. 2007)

Table 31. Cost model for seeding modified germplasms or ecological-bridge mixtures.................. 81

Table 32. Approximate costs of seeding moderately used lands at Fort Carson..............................84

Table 33. Precipitation and soil types at species-evaluation sites. 101

Table 34. Stand establishment of perennial grasses at Fort Carson Turkey Creek Site, seeded fall 1994.

Table 35. Mean percent stand of native and introduced grasses at Fort Carson South Boundary, seeded fall 1996.

Table 36. Seeding vigor ratings and percent stand of native and introduced perennial Triticeae grasses during stand establishment (1995) and subsequent years on Snake A site at Yakima Training Center.

Table 37. Seeding vigor ratings and percent stand of native and introduced perennial Triticeae grasses during stand establishment (1995) and subsequent years on Snake B site at Yakima Training Center. 105

Table 38. YTC Exit 11 monoculture and mixture seeding list (21-22 October 2002). 106

Table 39. Guernsey River site monoculture and mixture seeding list (31 March 2004). 107

Table 40. Guernsey Tower site monoculture and mixture seedings (23 March 2005).

Table 41. Dugway monoculture seeding list (7 November 2005).

Table 42. Yakima Training Center monocultures and mixes 6-month establishment on 14 May 2003 (48-grid frame with 6.35 x 6.35-cm squares).

Table 43. Yakima Training Center monocultures and mixes at 1.5 years on 19 April 2004 (24-grid frame with $12.7 \times 12.7$-cm squares).

Table 44. Yakima Training Center monocultures and mixes at 2.5 years in June 2005 (24grid frame with $12.7 \times 12.7$-cm squares).

Table 45. Guernsey River site establishment of monocultures and mixtures; data taken June 2, 2004 using three sub-samples in each replication (48-grid frame with $6.35 \mathrm{x}$ 6.35-cm squares).

Table 46. Guernsey River site, 1-year percent stand and weed data taken 2 June 2005 (24-grid frame; 12.7-x 12.7-cm squares)

Table 47. Guernsey River site 2-year percent stand, weed, litter, and bare ground data taken June 2006 (visual ratings).

Table 48. Camp Guernsey Tower site monoculture 2-month establishment data taken 2 June 2005 (48-grid frame; 6.35 x $6.35 \mathrm{~cm}$ squares). 
Table 49. Guernsey Tower site mix 2-month establishment data taken 2 June 2005 (48grid frame with $6.35 \times 6.35 \mathrm{~cm}$ squares).

Table 50. Guernsey Tower site 1-year percent stand, weed, litter, and bare ground data taken June 2006 (visual ratings).

Table 51. Fort Drum Airport site 1-year percent cover and bare ground on 24 June 2003.

Table 52. Fort Drum Airport site 2-year percent cover and bare ground on 29 June 2004.......... 147

Table 53. Fort Drum Airport site 3-year percent cover and bare ground on 7 September 2005.

Table 54. Fort Drum Airport site 4-year percent cover and bare ground on 7 June 2006

Table 55. Soil moisture, shear vane, and cone penetrometer data immediately before and after tracking (June 2005).

Table 56. Rut depth means by entry for all years after tracking (2005-2007).

Table 57. Percent cover of vegetation in June 2005 immediately after tracking.

Table 58. Percent cover of vegetation in June 2006, 1 year after tracking.

Table 59. Percent cover of vegetation in June 2007, 2 years after tracking.

Table 60. Establishment year stand of 'Recovery' western wheatgrass compared with standard western wheatgrass and other rangeland grass checks at 8 locations. Stand establishment measured as seedling frequency during the first May or June following a late-fall-dormant or early-spring planting. (Waldron et al. in prep).

Table 61. Second-year stand of 'Recovery' western wheatgrass compared with standard western wheatgrass and other rangeland grass checks at eight locations. Stand establishment measured as plant frequency during the second May or June following a late-fall-dormant or early-spring planting. (Waldron et al. in prep).

Table 62. Dry matter yield (DMY) of 'Recovery' western wheatgrass compared with standard western wheatgrass and other rangeland grass checks at three locations. Yield at Nephi and Blue Creek, UT evaluated just prior to anthesis in 2008 from 10-spacedplant plots established in 2005. Yield from Curlew Valley, ID determined in 2006 just prior to anthesis using 1- $\mathrm{m}^{2}$ clipped subsamples of plots established in 2002. (Waldron et al. in prep).

Table 63. Vavilov II Siberian wheatgrass stand establishment and persistence at Malta, Idaho, and Fillmore, Utah.

Table 64. Vavilov II Siberian wheatgrass establishment and persistence at YTC (established fall 2002).

Table 65. Vavilov II Siberian wheatgrass stand establishment and persistence at Curlew Valley, Idaho (established fall 2002).

Table 66. Vavilov II Siberian wheatgrass establishment and persistence at Camp Guernsey.

Table 67. Vavilov II Siberian wheatgrass dry matter yield at YTC and Camp Guernsey in 2005.

Table 68. Bozoisky II Russian wildrye percent stand establishment in 2001 in Northern Area Plains Regional Trials (NPA) established fall 1999 (Jensen et al. 2006).

Table 69. Bozoisky II Russian wildrye percent stand establishment at three additional sites (Jensen et al. 2006).

Table 70. Bozoisky II Russian wildrye persistence as measured by percent stand in 2003 at four NPA sites, established 1999 (Jensen et al. 2006). 
Table 71.Bozoisky II Russian wildrye dry matter forage yield at NPA trial sites (established fall 1999). 


\section{Preface}

Funding for the project was supplied by the Environmental Security Technology Certification Program (ESTCP) under Project SI-0401. The Army Environmental Command (AEC) supported additional aspects of the research, both financially and technically.

This report was prepared by Antonio J. Palazzo, Susan E. Hardy, and Timothy J. Cary of the Biogeochemical Sciences Branch, U.S. Army Engineer Research and Development Center (ERDC), Cold Regions Research and Engineering Laboratory (CRREL), Hanover, New Hampshire, and by Dr. Kevin Jensen, Dr. Blair Waldron, and Dr. Steven Larson, United States Department of Agriculture (USDA)-Agricultural Research Service, Logan, Utah.

The authors acknowledge Dr. Jeffrey Marqusee, Director, and Drs. Robert Holst and John Hall, Program Managers, former and present, ESTCP; Kim Watts and Bonnie Packer, AEC, for technical support; and John Thigpen, Carrie Wood, Kristen Lau, Lucia Valentino, Jennifer Rusk, and Susan Walsh at HydroGeoLogic, Inc., contractor for the ESTCP program.

Over the life of this program the authors have enjoyed and benefited from working with many people, including Dr. David Huff, Pennsylvania State University, for technical assistance, and Dan Ogle and Loren St. John, USDA-NRCS Plant Materials Center, Aberdeen, Idaho, for seed production. Many ERDC team members have helped make this program a success, including Nancy Perron, Dennis Lambert, and Troy Arnold for technician support. Dr. William Severinghaus, Robert Lacey, Alan Andersen, Dr. Dick Gebhart, Heidi Howard, and Ryan Busby at ERDCCERL provided technical support, and Gary Pasternak of CERL helped develop the memorandums of agreements between cooperating agencies.

The report was prepared under the general supervision of Dr. Terrence Sobecki, Chief, Biogeochemical Sciences Branch; Dr. Lance Hansen, Deputy Director; and Dr. Robert E. Davis, Director, CRREL. The Commander and Executive Director of ERDC was COL Gary E. Johnston. The Director was Dr. James R. Houston. 


\section{Terminology}

Breeders, foundation, and certified seed. Breeders seed is produced from the last cycle of selection. This seed is used to produce foundation seed, which, in turn, is used to establish certified seed fields from which seed is produced for commercial sale.

Cultivar vs. germplasm. Plant materials developed in this project were released as "cultivars" or a level of pre-variety "germplasm." A cultivar (sometimes called a variety) is a population that is unique for selected traits and that has undergone multiple cycles of selection and extensive testing over multiple locations. A cycle refers to a complete generation from seed to plant (selection) to seed. Cultivars are genetically stable. A germplasm (pre-cultivar) can be a single genotype or a collection of multiple genotypes from multiple origins that are unique for a given character, but have not undergone nor met the more rigorous requirements for a cultivar. Germplasms may be released as one of three levels-source-identified, selected, or tested class-depending on the level of selection or testing.

Introduced vs. naturalized vs. native species. In this report, we use the term introduced to represent species not indigenous to North America. Many of the introduced plant materials on western rangelands, including those in this project, originated in Central Asia where they occur in very different ecosystems. The superior stand-establishment characteristics, hardiness, wide adaptability, persistence under grazing, availability and lower cost of seed, and productivity of introduced perennial species compared with indigenous native species have been documented in many regions (Barker et al. 1977; Vallentine 1977; Kilcher and Looman 1983; Lawrence and Ratzlaff 1989). Like their native counterparts, introduced grasses have the capacity to sort by natural selection and improve their adaptation to the environmental conditions on sites where they are seeded. As a result, many of the introduced species included in the project are naturalized, having existed in stands for over 50 years. These naturalized species have co-existed with native flora on North American rangeland (both private and public) for years. Within this report, we use only the terms introduced and native, based on the species origin. 
Invasive. For the purposes of this study, we defined an invasive species as an introduced species that will spread beyond the areas it currently inhabits and prevent the establishment of desired perennial plants. We do not agree with definitions of invasive that equate it to any introduced or exotic species. Tiller and rhizome development and seedling encroachment through seed dispersal are potential indicators of invasiveness. Except for 'RoadCrest' crested wheatgrass, which is moderately rhizomatous and is best suited for cantonments and roadsides, we did not use any introduced species displaying these characteristics. On the other hand, rhizome development is valuable in desired native species for land stabilization and reclamation of disturbed lands. We worked with some rhizomatous natives to improve establishment and persistence of desired species.

Resiliency. We define resilient grasses as those better able to withstand training without being permanently damaged. This trait can be accomplished in two ways. Plants that establish more quickly will be larger and therefore more capable of withstanding training. Also, plants that can recover after being trained on (i.e., via rhizome spread) can adjust to changes in land use and maintain a vegetative sward. 


\section{Acronyms and Abbreviations}

ACOM

AEC

AFLP

AOSCA

ARS

ATTACC

CERL

CRREL

DoD

ECAM

EPA

ERDC

ESTCP

DPG

$\mathrm{FF}$

FORSCOM

HG

INRMPs

ITAM

LCTA

MRTFB

NGB

NPA

NRCS

PVP

RAPD
U.S. Army Command (formerly Forces Command, FORSCOM)

Army Environmental Command

Amplified Fragment Length Polymorphic

Association of Official Seed Certifying Agencies

Agricultural Research Service

Army Training and Testing Area Carrying Capacity

Construction Engineering and Research Laboratory

Cold Regions Research and Engineering Laboratory

Department of Defense

Environmental Cost Analysis Model

Environmental Protection Agency

Engineer Research and Development Center

Environmental Security Technology Certification Program

Dugway Proving Ground

fine fescues

Forces Command (Army); now ACOM

hairgrass

Integrated Natural Resources Management Plans

Integrated Training Area Management

Land Condition Trend Analysis (now RTLA)

Major Range Test Facility Base

National Guard Bureau

Northern Plains Area Regional Trials

Natural Resource Conservation Center

Plant Variety Protection

Random Amplified Polymorphic DNA 


$\begin{array}{ll}\text { ROD } & \text { Record of Decisions } \\ \text { RTLA } & \text { Range and Training Land Assessment (formerly LCTA) } \\ \text { SERDP } & \begin{array}{l}\text { Strategic Environmental Research and Development } \\ \text { Program }\end{array} \\ \text { SI } & \text { sustainable infrastructure } \\ \text { SRP } & \text { Sustainable Range Program } \\ \text { SG } & \text { switchgrass } \\ \text { USDA } & \text { U.S. Department of Agriculture } \\ \text { WL } & \text { weeping lovegrass } \\ \text { WYARNG } & \text { Wyoming Army National Guard } \\ \text { YTC } & \text { Yakima Training Center }\end{array}$




\section{List of Plant Species Used in Project}

\begin{tabular}{|c|c|c|}
\hline Common name & Scientific name & Range relative to US \\
\hline Alfalfa & Medicago sativa & Introduced \\
\hline Basin wildrye & Leymus cinereus (Scribn. \& Merr.) Á. Löve & Native (Western U.S.) \\
\hline Beardless wildrye & Leymus triticoides (Buckley) Pilg. & Native (western U.S.) \\
\hline Bering hairgrass & Deschampsia beringénsis & $\begin{array}{l}\text { Native (northeastern and } \\
\text { western US) }\end{array}$ \\
\hline Big sagebrush & Artemisia tridentata & Native \\
\hline Bluebunch wheatgrass & Pseudoroegneria spicata (Pursh) A. Löve & Native (western US) \\
\hline Blue gramma & Bouteloua gracillis & Native (western US) \\
\hline Buffalograss & Bouteloua dactyloides (Nutt.) J.T. Columbus & Native (midwestern US) \\
\hline Cheatgrass & Bromus tectorum $\mathrm{L}$. & Introduced invasive weed \\
\hline $\begin{array}{l}\text { Crested wheatgrass (Fairway } \\
\text { type) }\end{array}$ & Agropyron cristatum (L.) Gaertn. & Introduced \\
\hline $\begin{array}{l}\text { Crested wheatgrass (Standard } \\
\text { type) }\end{array}$ & $\begin{array}{l}\text { Agropyron desertorum (Fisch. ex Link) } \\
\text { Schult. }\end{array}$ & Introduced \\
\hline Forage kochia & Kochia prostrata sp. virescens & Introduced shrub \\
\hline Hard fescue & Festuca brevipila R. Tracey & Introduced \\
\hline Kentucky bluegrass & Poa pratensis $L$. & Native (northern US) \\
\hline Little bluestem & $\begin{array}{l}\text { Schizachyrium scoparium (Michx.) Nash var. } \\
\text { scoparium] }\end{array}$ & Native \\
\hline Medusahead rye & Taeniatherum asperum (Simonk.) Nevski & Introduced invasive weed \\
\hline Purple needlegrass & Nassella pulchra (Hitchc.) Barkworth & Native (California) \\
\hline Russian wildrye & Psathyrostachys juncea (Fisch.) Nevski & Introduced \\
\hline Sandberg bluegrass & Poa secunda J. Presl & Native (western US) \\
\hline Sheep fescue & Festuca ovina L. & Introduced \\
\hline Siberian crested wheatgrass & Agropyron fragile (Roth) P. Candargy & Introduced \\
\hline Slender wheatgrass & $\begin{array}{l}\text { Elymus trachycaulus (Link) Gould ex } \\
\text { Shinners }\end{array}$ & Native \\
\hline Snake River wheatgrass & Elymus wawawaiensis ined. & Native (northwestern US) \\
\hline Switchgrass & Panicum vergatum $\mathrm{L}$. & Native \\
\hline Tall fescue & Festuca arundinacea Schreb. & Introduced \\
\hline Thickspike wheatgrass & $\begin{array}{l}\text { Elymus lanceolatus (Scribn. \& J. G. Sm.) } \\
\text { Gould }\end{array}$ & Native \\
\hline Tufted hairgrass & Deschampsia cespitosa (L.) P. Beauv. & $\begin{array}{l}\text { Native (northeastern and } \\
\text { western US) }\end{array}$ \\
\hline Weeping lovegrass & Eragrostis curvula (Schad.) Nees & Introduced \\
\hline Western wheatgrass & Pascopyrum smithii (Rydb.) Á. Löve & Native (western US) \\
\hline Western yarrow & Achillea millefolium L. & Native forb \\
\hline
\end{tabular}




\section{Introduction}

\subsection{Background}

The Department of Defense (DoD) must constantly balance its military mission and its commitment to stewardship as it operates millions of acres of ranges and training lands. The military mission requires that vegetation - primarily grasses - be as resilient to military training activities as possible to maintain realism and to control soil erosion.

The military faces increasingly difficult land-management challenges as weapons technology improves and training and testing needs change. Complicating this challenge is the impact of continuing development, especially urbanization, outside the boundaries of military installations. As populations grow and urban expansion continues, landscapes around facilities will be further degraded, and additional pressures will likely be brought to bear on native species, biological communities, and the ecological processes that sustain them. This growing pressure may intensify demands that federal land managers take on even greater responsibilities for biodiversity conservation (Keystone Center 1996).

When indigenous species are lost, undesirable or invasive annual species often grow in those same areas. Invasive annual plants are a problem on military lands because (1) they can reduce training realism, (2) they do not retard soil erosion as well as do perennial species because they leave the land barren during the winter months, (3) operations to detect and control them use valuable mission resources, and (4) they can take over and destroy the habitat for desirable or threatened and endangered species. The prevalent method for controlling invasive plants on military lands is herbicide application, but this option was reduced beginning in 2001. Research on pest or animal control of invasive plants is currently active in many public weed-control programs, but there is limited knowledge of the interrelationships of invasive and desirable plant species. To compete with the annual invasive or noxious weeds, sown species should germinate readily and have rapid growth rates soon thereafter.

Our goals have been both to develop plants more resilient to military training activities and to get native plants to establish more rapidly so that the land could more quickly be returned to military use. Through our 
Strategic Environmental Research and Development Program (SERDP) project to "Identify resilient plant characteristics and develop a wearresistant plant cultivar for use on military training lands" (Sustainable Infrastructure project SI-1103), we bred native and introduced grass and forb germplasms with improved establishment and seedling vigor. We also developed seeding methods to further enhance the ability of our modified germplasms to establish viable native plant stands as rapidly as possible. Our modified germplasms may be used over a broad area of the Intermountain West Region of the U.S., and our seeding methods have proven successful on eastern and western ranges (Fort Drum, New York; Yakima Training Center, Washington; and Fort Carson, Colorado). During the SERDP project (Palazzo et al. 2003), we began some large-scale demonstrations and held a workshop for federal, state, and regional land managers as well as representatives of seed companies (Hardy and Palazzo 2002). The goals of this ESTCP project were to further demonstrate and validate the germplasms and our seeding methods and to make the modified seeds available to land managers.

Before our efforts, there was little or no research on the genetics or resiliency of low-maintenance rangeland plants. In our plant-breeding research, we were able to improve traits related to establishment and resiliency to training activities in introduced and native species of rangeland grass plants, compared to existing, commercially available cultivars. We recognized, however, that even with their improved establishment rates, our new germplasms would not always be able to compete with the very aggressive establishment of annual invasive plants.

To find better ways to establish native plants, we developed the concept of "ecological bridges." In this innovative work, we investigated root growth and establishment relationships among various species and, from this knowledge, selected seed mixes of those rapidly establishing introduced grasses and desired native grasses. The species of introduced grasses selected varied with climatic and land-use conditions, but the primary criterion was for this plant to be relatively short-lived so that a native vegetative stand would develop. When properly selected, the introduced grasses will quickly protect the soil and create an environment in which the native grasses would gradually establish and dominate the seeded stand (Waldron et al. 2005). We also addressed the potential invasiveness of the germplasms we were developing by convening an independent review panel at Yakima Training Center in 1999 to evaluate the species, 
especially the introduced ones, we were using in the breeding studies. The panel concluded that the plants were not encroaching into other plant communities and were not establishing monocultures (Palazzo et al. 1999).

\subsection{Objectives of the demonstration}

Our objective in this current ESTCP project was to bring the new germplasms and seeding methods to widespread use on DoD and other federal lands by demonstrating and further validating the new plant materials and seeding methodologies, investigating the release of cultivars, initiating seed contracts, and developing a planting guide for military facilities in the intermountain west. New plant materials are needed since many of the cultivars or germplasms of species purchased for use on military lands were originally developed for other uses such as for grazing. To accomplish this, we performed field evaluations and demonstrations of the new germplasms compared to existing cultivars of the same species and also compared seeding mixtures to standard military mixes. The comparative evaluations of the new germplasms enabled us to select germplasms suited for military lands. The technical differences of the new germplasms as compared to existing cultivars were documented through field or greenhouse evaluations.

The results of these comparisons were summarized in release notices published in either the journal Crop Science or the J ournal of Plant Registrations. The release notices are a form of announcement that these plants have been developed and are available for production and distribution. The notices define the species and note how they are different from the more important cultivars or germplasms of the species currently on the commercial market.

The germplasms were released as either cultivars, selected class, or sourceidentified germplasms. Our aim was to bring as many germplasms as possible to full cultivar status, and we were successful for four species to date and potentially one more (two cultivars were released earlier during our SERDP project). In addition, those released as selected or sourceidentified germplasms remain desirable and should enjoy a market demand for the seed.

The comparative field evaluations of new germplasms with existing cultivars were conducted at Camp Guernsey, Wyoming; Fort Carson, Colorado; Yakima Training Center, Washington; and Dugway Proving 
Ground (DPG), Utah. The demonstrations of ecological-bridge seed mixtures took place at Camp Guernsey, Wyoming; Yakima Training Center (YTC), Washington; and Fort Drum, New York. Additional cultivar evaluations were conducted at ERDC-CRREL and at various U.S. Department of Agriculture - Agricultural Research Service (USDA-ARS) nursery fields.

The only toxic compounds that might be used in demonstrations and evaluations, or in future applications of the products, are EPA-approved herbicides applied at the recommended rates. There are no waste stream emissions involved in the technology, nor, with the exception of the herbicide types and application rate, are there any applicable regulatory standards. Instead, the modified germplasms and establishment methods will reduce the overall need for herbicide applications in controlling noxious weeds at seeding time, and they will decrease the number of reseedings required in some situations. The technology will therefore allow training to occur again more rapidly, increase the diversity of species on the land, and reduce the likelihood of sediment or runoff from erosion.

\subsection{Regulatory drivers}

To be effective, the training mission must provide the resources for the military to meet their mission effectively. Military lands must be maintained in settings that provide the opportunity to practice individual and battle-focused tasks and missions in both realistic and challenging conditions. Throughout the DoD, land stewardship and management of its natural resources fall under the Sikes Act of $1960,{ }^{1}$ which promotes "effective planning, development, maintenance, and coordination of wildlife, fish, and game conservation and rehabilitation in military reservations on military lands." In Army Regulation AR200-1, ${ }^{2}$ the Army military land stewardship integrates natural resources management objectives with land warfare training requirements. Environmental compliance requirements that address these issues include sections: 2.1.b "...Range and Road Maintenance" and 2.5.e "Sustainable Army Live-Fire Range Design and Maintenance.” The management of lands is funded and

1 Sikes Act (16 USC 670a-670o, 74 Stat. 1052), as amended, Public Law 86-797, approved September 15, 1960. Available at: http://www.fws.gov/laws/lawsdigest/SIKES.HTML

2 Army Regulation 200-1. Environmental quality, Environmental Protection and Enhancement. Headquarters, Department of the Army, Washington, DC. 13 December 2007. Available at: http://www.apd.army.mil/pdffiles/r200_1.pdf 
prioritized through the Integrated Natural Resources Management Plans (INRMPs) process used at every military facility.

Our research objectives addressed these adversities by developing plant materials and seeding methods to help installations be good stewards of land resources while supporting the Sikes Act and its provisions for no net loss of training land. 


\section{Technology}

\subsection{Technology description}

Prior to this demonstration, we conducted basic and applied research to develop the technology. We researched modified plant materials as well as methods of establishing and maintaining native plant stands on military lands through two consecutive Corps of Engineers basic research projects on determining the genetic diversity of native plants, a SERDP project (SI1103) on breeding the new germplasms, and leveraged funding from the Army Forces Command (FORSCOM), Army Environmental Command (AEC), and the Wyoming National Guard Bureau (NGB) to implement our evaluations. With this funding, we made significant advances in using molecular markers to identify species and genetic diversity within species (Liu et al. 1997; Larson et al. 1999, 2000, 2001, 2003, 2006; Hu et al. 2000, 2001, 2005).

For genetic diversity, we now have the tools to assess the genetic differences and similarities in commercial and natural seed sources. These studies provided us with background knowledge of the state of genetic diversity and plant characteristics of native plants existing on military training lands. A natural extension of this earlier research was our desire to use that knowledge as a baseline to modify plant materials to improve low-maintenance, training-resilient, native vegetation on military lands without causing significant changes in genetic diversity on those lands.

We used traditional plant-breeding practices to develop modified germplasms (Figure 1). We surveyed representative DoD installations to identify the most promising species along with the characteristics in those species associated with resiliency to training activities. We collected native plants with the desired traits from training lands and other conservation lands, and we used the best lines of introduced species already assembled in nurseries at USDA-ARS and Pennsylvania State University. From nurseries and seeded evaluation trials from 1995 through 1998, we selected the most promising species to carry forward in the breeding program. In our program, breeding populations were typically subjected to two cycles of selection for traits such as stand-establishment vigor, rate of tillering and rhizome development, vegetative vigor, and seed-yield potential. 


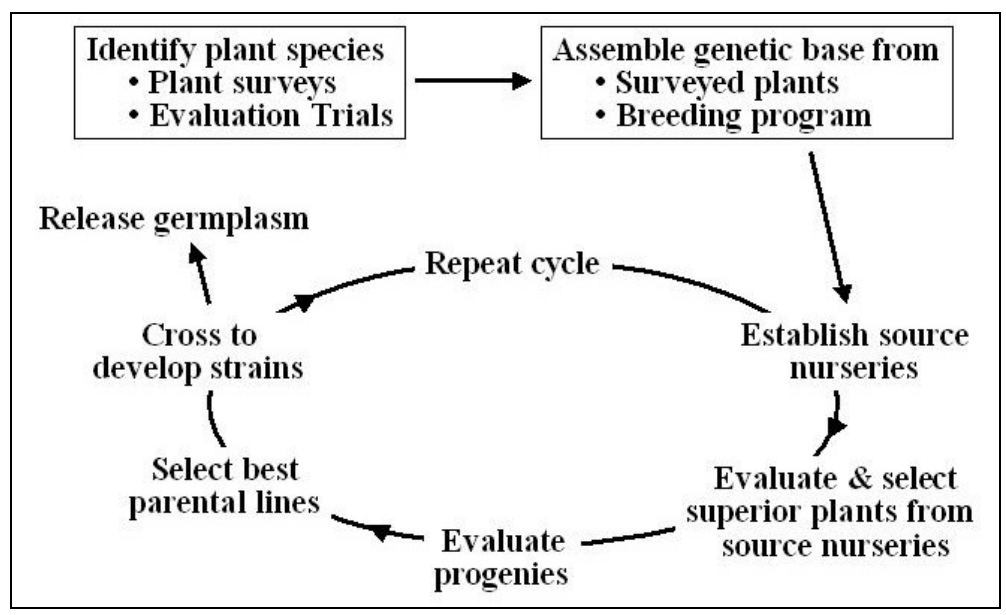

Figure 1. Plant-breeding cycle.

Although the main emphasis of the breeding program was on improving native species, introduced species were included early in the program. To ensure that the introduced germplasms we developed would not dominate lands currently inhabited by native species or prevent the return of native plants in the future, we convened an Independent Review Panel in May 1999 to evaluate the introduced species we were using in the breeding program. After evaluating 4- to 19-year-old plots at Yakima Training Center that had been seeded with the standard commercial cultivars of that time, the panel found that the species we were using were not encroaching into other plant communities and were not establishing monocultures (Palazzo et al. 1999). Although these plantings were too early to have included our modified germplasms, the panel found that the introduced species were filling in gaps but not spreading and pushing out native species, and thus were good candidates for our program.

We made four releases before the ESTCP project began (Asay et al. 1997, 1999; Jensen et al. 1998; Jones et al. 2002) and six more through the duration of the ESTCP project (Jensen et al. 2006, 2007, 2009; Waldron et al. 2006a, 2006b, in press). One additional release, a possible cultivar, is expected in the next year or two. Table 1 lists the current status and significant traits of each modified germplasm. 
Table 1. Modified traits and current status of SERDP-select germplasms; (bold type indicates released germplasms).

\begin{tabular}{|c|c|c|c|}
\hline Introduced selections & Original traits & Traits of modified populations & Release \\
\hline \multicolumn{4}{|l|}{ Russian wildrye } \\
\hline RWR-Tetra-1 & $\begin{array}{l}\text { Poor seedling } \\
\text { vigor }\end{array}$ & $\begin{array}{l}\text { Selected for improved seed germination and } \\
\text { seedling vigor, increased plant height, longer and } \\
\text { wider leaves, increased seedling emergence, } \\
\text { heavier seeds, improved water-use efficiency }\end{array}$ & $\begin{array}{l}\text { Jones et al. } \\
1998 \text { (source- } \\
\text { identified) }\end{array}$ \\
\hline Syn A & & $\begin{array}{l}\text { Improved seed germination. Part of parent } \\
\text { population to develop Bozoisky-II }\end{array}$ & Not released; \\
\hline 'Bozoisky-II' & & $\begin{array}{l}\text { Selected for improved seed germination and } \\
\text { seedling vigor }\end{array}$ & $\begin{array}{l}\text { Jensen et al. } \\
2006 \text { (cultivar) }\end{array}$ \\
\hline \multicolumn{4}{|l|}{ Crested wheatgrass } \\
\hline ‘CD-II’ & $\begin{array}{l}\text { Moderate } \\
\text { growth in cool } \\
\text { temperatures; }\end{array}$ & $\begin{array}{l}\text { Selected for increased growth under cold } \\
\text { temperatures, drought resistance, easy } \\
\text { establishment }\end{array}$ & $\begin{array}{l}\text { Asay et al. } 1997 \\
\text { (cultivar) }\end{array}$ \\
\hline 'RoadCrest' & Few rhizomes & $\begin{array}{l}\text { Selected for low-maintenance turf with moderate } \\
\text { rhizome development; suitable for gunnery ranges } \\
\text { and roadside plantings; early spring growth }\end{array}$ & $\begin{array}{l}\text { Asay et al. } 1999 \\
\text { (cultivar) }\end{array}$ \\
\hline $\begin{array}{l}\text { Siberian wheatgrass } \\
\text { 'Vavilov II' }\end{array}$ & $\begin{array}{l}\text { Moderate } \\
\text { seedling vigor }\end{array}$ & $\begin{array}{l}\text { Selected for seedling vigor, plant color, vegetative } \\
\text { vigor, seed yield, drought tolerance, early spring } \\
\text { green-up }\end{array}$ & $\begin{array}{l}\text { Jensen et al. } \\
2009 \text { (cultivar) }\end{array}$ \\
\hline Native selections & Original traits & Traits of modified populations & Release date \\
\hline $\begin{array}{l}\text { Bluebunch wheatgrass } \\
\text { P-7 }\end{array}$ & $\begin{array}{l}\text { Hard to } \\
\text { establish; } \\
\text { sensitive to } \\
\text { grazing }\end{array}$ & $\begin{array}{l}\text { A broad-based multi-line population with no } \\
\text { selection pressure applied }\end{array}$ & $\begin{array}{l}\text { Jones et al. } \\
2002 \text { (selected- } \\
\text { class) }\end{array}$ \\
\hline $\begin{array}{l}\text { Western wheatgrass } \\
\text { 'Recovery' }\end{array}$ & $\begin{array}{l}\text { Strongly } \\
\text { rhizomatous }\end{array}$ & $\begin{array}{l}\text { Selected for plant and seedling vigor, increased } \\
\text { germination, seed yield }\end{array}$ & $\begin{array}{l}\text { Waldron et al. in } \\
\text { press (cultivar) }\end{array}$ \\
\hline $\begin{array}{l}\text { Snake River } \\
\text { wheatgrass }\end{array}$ & Seedling vigor & $\begin{array}{l}\text { Selected for increased seedling vigor and seed } \\
\text { yield }\end{array}$ & $\begin{array}{l}2011 \text { (potential } \\
\text { cultivar) }\end{array}$ \\
\hline \multicolumn{4}{|l|}{ Slender wheatgrass } \\
\hline 'FirstStrike' & $\begin{array}{l}\text { Poor } \\
\text { persistence }\end{array}$ & $\begin{array}{l}\text { Broad-based bunch-type population selected for } \\
\text { emergence from a deep planting depth; improved } \\
\text { plant vigor }\end{array}$ & $\begin{array}{l}\text { Jensen et al. } \\
2007 \text { (cultivar) }\end{array}$ \\
\hline $\begin{array}{l}\text { Rhizomatous } \\
\text { population }\end{array}$ & Persistent & $\begin{array}{l}\text { Selected for same as above plus rhizome } \\
\text { development }\end{array}$ & dropped \\
\hline Basin wildrye & $\begin{array}{l}\text { Poor seedling } \\
\text { vigor }\end{array}$ & $\begin{array}{l}\text { Selected for improved seed germination and } \\
\text { seedling vigor, increased plant height, longer and } \\
\text { wider leaves, increased seedling emergence, } \\
\text { heavier seeds, improved water-use efficiency }\end{array}$ & dropped \\
\hline $\begin{array}{l}\text { Sandberg bluegrass } \\
\text { Reliable }\end{array}$ & $\begin{array}{l}\text { Early establish- } \\
\text { ment after a } \\
\text { disturbance }\end{array}$ & $\begin{array}{l}\text { A broad-based multi-line population with no } \\
\text { selection pressure applied }\end{array}$ & $\begin{array}{l}\text { Waldron et al. } \\
\text { 2006a (selected- } \\
\text { class) }\end{array}$ \\
\hline $\begin{array}{l}\text { Western yarrow } \\
\text { (a forb) } \\
\quad \text { Yakima }\end{array}$ & & $\begin{array}{l}\text { A broad-based multi-line population with no } \\
\text { selection pressure applied }\end{array}$ & $\begin{array}{l}\text { Waldron et al. } \\
2006 b \text { (source- } \\
\text { identified class) }\end{array}$ \\
\hline
\end{tabular}


As part of our SERDP breeding project, we studied the use of non-invasive introduced grasses as an "ecological bridge" to the establishment of native grasses (Palazzo et al. 2003; Waldron et al. 2005) at Yakima Training Center, Washington; Fort Drum, New York; and Fort Carson, Colorado. We have promoted the concept at professional meetings and workshops with other federal and state agencies (Cary et al. 2001; Hardy and Palazzo 2002; Palazzo et al. 2001, 2002, 2006, 2007; Loffredo, et al., 2007). The concept has been well received and has gained interest with researchers and land managers. For example, the seeding mixtures we tested at Fort Drum now comprise the standard for that facility's ranges (Palazzo et al. 1996, 2006, 2007; Hardy and Palazzo 2002).

The basic concept in the use of ecological bridge seedings is to select a geographically and climatically appropriate seed mixture of desired natives plus one or more rapidly establishing, introduced species that are not persistent. The introduced species provide an early protective vegetative cover to allow the natives to establish and eventually dominate the stand (Figure 2).

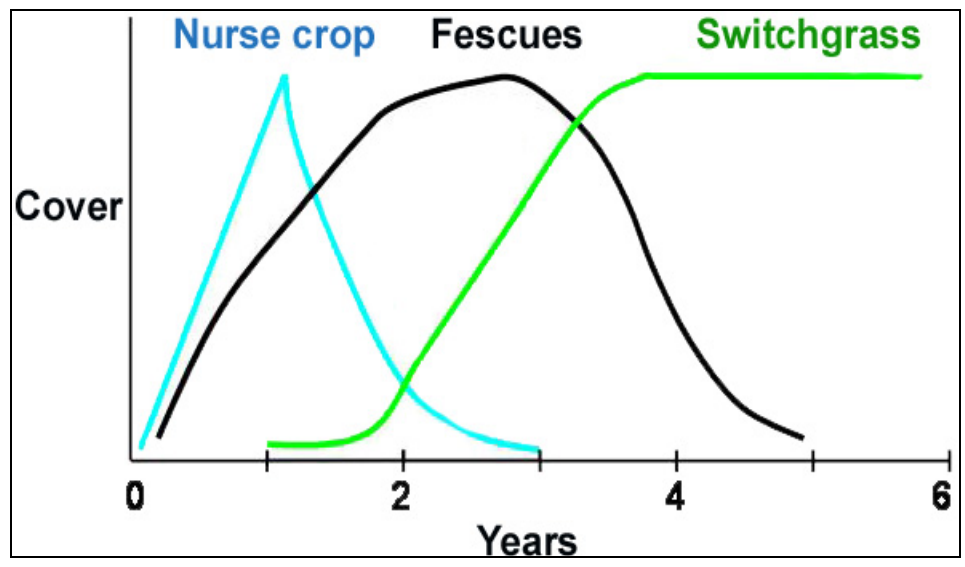

Figure 2. A conceptual model on how an introduced nurse-crop species acts as an "ecological bridge" on sandy soils at Fort Drum, allowing fescues and eventually the desired native grass, switchgrass, to become established.

In spring 2002, we held a 2-day workshop at Fort Carson and the Air Force Academy (Hardy and Palazzo 2002) to introduce land managers and seed companies to the modified germplasms and mixed seeding methods. The workshop was well received, and both users and commercial growers were interested in our new plant materials. Since this workshop, we have visited military facilities many times in the Intermountain West, presented posters or oral briefings at the Integrated Training Area Management (ITAM) or the Sustainable Range Program (SRP) meetings, and established 
demonstration studies at four facilities to explain and show the benefits of the new germplasms.

Our new plant materials and seeding methods provide improved plant persistence on all military lands at a reduced environmental risk with respect to habitat loss and soil erosion. As native grass stands are established more quickly, military ranges will have decreased down times, offering reduced unit-training costs, increasing the value and use of current training areas, and enhancing DoD mission-related environmental activities.

No new equipment or skills are needed to use the new germplasms or seeding methods. "Implementation" of this technology requires the proper decision making for selecting appropriate revegetation materials. We have prepared a planting guide (Palazzo et al. 2009) that includes detailed information on plant selection for specific microclimatic ranges, training scenarios, and locations for optimal uses for each modified germplasm, as well as guidelines for selecting appropriate ecological bridge seed mixes.

\subsection{Technology development}

During the breeding process, candidate populations were tested at YTC, Fort Carson, and at breeding nurseries in Utah. Our final SERDP report (Palazzo et al. 2003) describes all of the evaluations performed during breeding and plant development. Related trials of many of the species modified in the breeding program are described by Asay et al. (2001) and Jensen et al. (2000). The ecological-bridge concept was tested at YTC, Fort Carson, and Fort Drum. This section presents the results of the breeding and ecological-bridge aspects of our earlier research.

\subsubsection{Breeding resilient plants}

The breeding program consisted of the following stages:

- Assess: We assembled a broad genetic base and selected the best accessions and clonal lines for desired characteristics.

- Develop: We made crosses among the best lines to produce progeny, conducted parent-progeny tests to initiate the second breeding cycle, and continued the breeding cycle as necessary. 
- Test and evaluate: We tested new strains in replicated seeded trials and in soil compaction trials in the field. We also evaluated the new strains to ensure that they would not become invasive, and we analyzed the genetic diversity of the new strains.

In the assessment stage, we surveyed representative DoD installations to identify the most promising introduced and native species as well as the characteristics associated with resiliency in those species. Through research funded by Army FORCOM [now U.S. Army Command (ACOM)], we had already identified resilient plant species at several training sites using field surveys and the data generated by the ERDC-CERL Integrated Training Area Management (ITAM)-Land Condition Trend Analysis (LCTA) program [now the Range and Training Land Assessment (RTLA) program]. The LCTA program included monitoring of vegetation dominance on lands subjected to military training and provided information on the resiliency, persistence, and adaptation of plant species.

While making field collections, we identified plant characteristics that are critical to soil conservation, plant survival, and training resiliency. These traits included a vigorous ground cover; a deep, fibrous root system; tiller and rhizome development; initiation of growth early in the spring; persistence under environmental extremes (temperature and drought); and rapid establishment of seedling and plant. Table 2 shows the species used in the early assessment trials. 
Table 2. Plant species used in pre-breeding trials.

\begin{tabular}{|c|c|c|c|}
\hline \multicolumn{3}{|c|}{ Native Grasses } & Introduced Grasses \\
\hline $\begin{array}{l}\text { Bluebunch } \\
\text { wheatgrass }\end{array}$ & $\begin{array}{l}\text { Thurber's } \\
\text { needlegrass }\end{array}$ & Lovegrass & Crested wheatgrass \\
\hline $\begin{array}{l}\text { Snake River } \\
\text { wheatgrass }\end{array}$ & Green needlegrass & Blue grama & Siberian wheatgrass \\
\hline Wheatgrass hybrid & Idaho fescue & Side Oats grama & $\begin{array}{l}\text { Intermediate } \\
\text { wheatgrass }\end{array}$ \\
\hline Western wheatgrass & Sheep fescue & Buffalograss & Russian wildrye \\
\hline Slender wheatgrass & Sandberg bluegrass & $\begin{array}{l}\text { Prairie Sandreed } \\
\text { grass }\end{array}$ & Giant wildrye \\
\hline $\begin{array}{l}\text { Thickspike } \\
\text { wheatgrass }\end{array}$ & Canby bluegrass & Little bluestem & \\
\hline $\begin{array}{l}\text { Bottlebrush } \\
\text { squirreltail }\end{array}$ & Indian ricegrass & Sand dropseed & \\
\hline Basin wildrye & $\begin{array}{l}\text { Needle and thread } \\
\text { grass }\end{array}$ & Galleta grass & \\
\hline & $\begin{array}{c}\text { Introduced Forbs, } \\
\text { Legumes, and Shrubs }\end{array}$ \\
\hline \multicolumn{2}{|c|}{$\begin{array}{l}\text { Native Forbs and Legumes } \\
\text { Spiny Hopsage }\end{array}$} & & Forage kochia \\
\hline Small burnett & \multicolumn{2}{|l|}{ Fourwing saltbrush } & Cicer milk vetch \\
\hline Bitterbrush & \multicolumn{2}{|l|}{ Globemallow } & Alfalfa \\
\hline
\end{tabular}

To assemble the best lines for the introduced breeding populations, we looked for the desired characteristics among the plant materials already assembled in nurseries at USDA-ARS and Pennsylvania State University. To assemble the native breeding populations, we collected plants with the desired traits from training sites and other conservation lands.

We planted the assembled promising species in seeded evaluation trials at YTC and Fort Carson during the fall of 1994 and 1996. More than 60 cultivars, breeding lines, and plant accessions directly from the training sites were included in the YTC trials. Over 40 cultivars, breeding lines, and material indigenous to the training sites were included at Fort Carson. Visual percent stand and vigor ratings were taken throughout 1995, 1996, 1997, and 1998. From the nurseries and the seeded assessment trials, we selected the most promising species for the breeding process. Appendix Section D.1 contains data obtained during these initial pre-breeding evaluation trials.

In summary, the trials confirmed that introduced species established better than natives, with the natives usually taking $2-3$ years to attain a stand greater than $50 \%$. The findings suggest that adapted introduced grasses should be considered along with native grasses as a component of seed mixtures on environmentally harsh or degraded sites. 
We used traditional plant-breeding techniques to combine desired traits into breeding populations. Figure 1 (above) shows a typical breeding program from plant surveys to germplasm release. Under normal conditions, it takes 2-3 years to complete one cycle of selection. The first year is a field-establishment year with no selection. The second and third years are for trait selection and seed harvest. If hybridization between selected clones is desired, it can take an additional year for isolation and seed increase for generation advance. With the exception of conducting plant surveys and assembling a broad genetic base (represented by the boxes at the top of Figure 1), the breeding cycle is repeated until the population has become genetically stable for the improved traits; each cycle increases the frequency of genes conditioning increased adaptation or specific traits. At some point after selection, the population is genetically stable from one generation to the next for the desired traits and may be released as a germplasm or, with more intense testing, as a cultivar.

In our program, we typically took plants through two cycles of selection. Most selections of parental lines where performed by analyzing measurable traits such as stand-establishment vigor, rate of tillering and rhizome development, vegetative vigor, and seed-yield potential. Native grasses with seed-dormancy problems were screened for more rapid germination. For future use, we used Random Amplified Polymorphic (RAPD) DNA or Amplified Fragment Length Polymorphic (AFLP) DNA analyses to identify genetic markers for desirable traits in some of the species. We also used both RAPD and AFLP DNA analyses to compare the genetic diversity of several new strains to their available counterparts.

Some new germplasms were not subjected to selection pressure. Instead, they were assembled from broad ecological ranges, resulting in a broader genetic base than in any of the individual populations and the subsequent potential to be better adapted to a wide range of different ecotypes.

Based on data from our field surveys and the seeded evaluation trials, we selected the three introduced and seven native species to carry forward in our breeding program to develop the new germplasms. The previously provided Table 1 lists those species and the current status of each.

Prior to formal release, cycle-2 breeding populations were established in seeded trials under a range of environmental conditions. Data obtained 
from these trials were used to write up the formal release notices, which include areas of adaptation. Seed from cycle-2 populations-breeders seed-was also used to establish foundation seed-increase fields for those species that have been contracted for further seed increase and for commercial release as certified seed.

As noted earlier, we established an Independent Review Panel to assess whether the introduced species of interest are a threat to invade habitats other than those currently occupied by the species. For this review, we evaluated a site established 5 years earlier at YTC. We evaluated the species for spread (through either vegetative tillering or reseeding) after 4 years growth by counting plants growing outside the plots where they were planted. The Independent Review Panel met at YTC to view the sites and to discuss and make a definitive statement on the potential invasiveness of the plant materials. Although these plantings were too early to include our modified germplasms for those species, the panel found that the introduced species were filling in gaps but not spreading and pushing out native species, and thus were good candidates for our program.

\subsubsection{Developing the ecological-bridge concept}

The ecological-bridge concept was tested at YTC, Washington; Fort Carson; and Fort Drum.

At YTC, we tested the hypothesis that introduced Siberian wheatgrass could act as an ecological bridge to the establishment of the native bluebunch wheatgrass in a cheatgrass-infested area. The study was seeded on disturbed sites at Yakima Training Center in November 1998. We used Snake River wheatgrass (native), bluebunch wheatgrass (native), and Vavilov Siberian wheatgrass (introduced) planted in monocultures of each grass, planted in binary seed mixtures of Vavilov with each native grass, and planted in alternating rows of Vavilov with each native grass. Table 3 shows the percentage of cheatgrass in each plot in 2000, 2 years after establishment. Plots with Vavilov had lower amounts of cheatgrass. Significant reductions in cheatgrass occurred when Vavilov was planted in alternating rows with bluebunch or Snake River wheatgrass as compared with each of those natives planted without Vavilov. In the Vavilov and bluebunch combinations, Vavilov allowed bluebunch to get established (Palazzo et al. 2003). 
Table 3. Percentage of cheatgrass in establishment-study plots at Yakima Training Center in 2000 ( 2 years after establishment).

\begin{tabular}{|c|c|c|c|}
\hline \multirow[b]{2}{*}{ Grasses } & \multicolumn{2}{|c|}{ Row Spacing } & \multirow[b]{2}{*}{ Mean } \\
\hline & $25 \mathrm{~cm}$ & $35 \mathrm{~cm}$ & \\
\hline Bluebunch wheatgrass & 53 & 65 & 59 \\
\hline Snake River wheatgrass & 35 & 78 & 57 \\
\hline Vavilov Siberian wheatgrass & 7 & 30 & 19 \\
\hline Bluebunch/Snake River Mix & 57 & 70 & 64 \\
\hline Bluebunch/Snake River Alternating Rows & 30 & 52 & 41 \\
\hline Bluebunch/Vavilov Mix & 17 & 47 & 32 \\
\hline Bluebunch/Vavilov Alternating Rows & 30 & 52 & 41 \\
\hline Snake River/Vavilov Mix & 25 & 48 & 36 \\
\hline Snake River/Vavilov Alternating Rows & 25 & 48 & 36 \\
\hline Bluebunch/Snake River/Vavilov Mix & 16 & 50 & 33 \\
\hline Mean & 32 & 56 & 44 \\
\hline $\operatorname{LSD}(0.05)$ & 23 & 19 & 15 \\
\hline
\end{tabular}

At Turkey Creek, Fort Carson, we evaluated mixtures of native and introduced grasses in plantings (Waldron et al. 2005). Dormant-seeded in the fall of 1997, the treatments involved a core native-grass mix plus one of five additional introduced grasses. For comparison, the Fort Carson standard mix was also seeded at increased rates to match the above treatments. The plots were evaluated in 1999, 2000, and 2001 for species composition, percent ground cover, percent annual and biennial weeds, percent introduced grasses, and percent natives. After 3 years, all mixes resulted in stands with less than $5 \%$ weeds, but there was variation in how quickly weeds were suppressed and in how predominant the native species were in the stands after 3 years (Figure 3). The mixes with crested or Siberian wheatgrasses as the introduced species had the fewest weeds in all 3 years but resulted in the lowest establishment of native species. The mixtures with a Russian wildrye as the introduced grass had at least $60 \%$ natives from the first year on and resulted in the most diverse stands of natives, but the weeds were stronger in the first 2 years. 


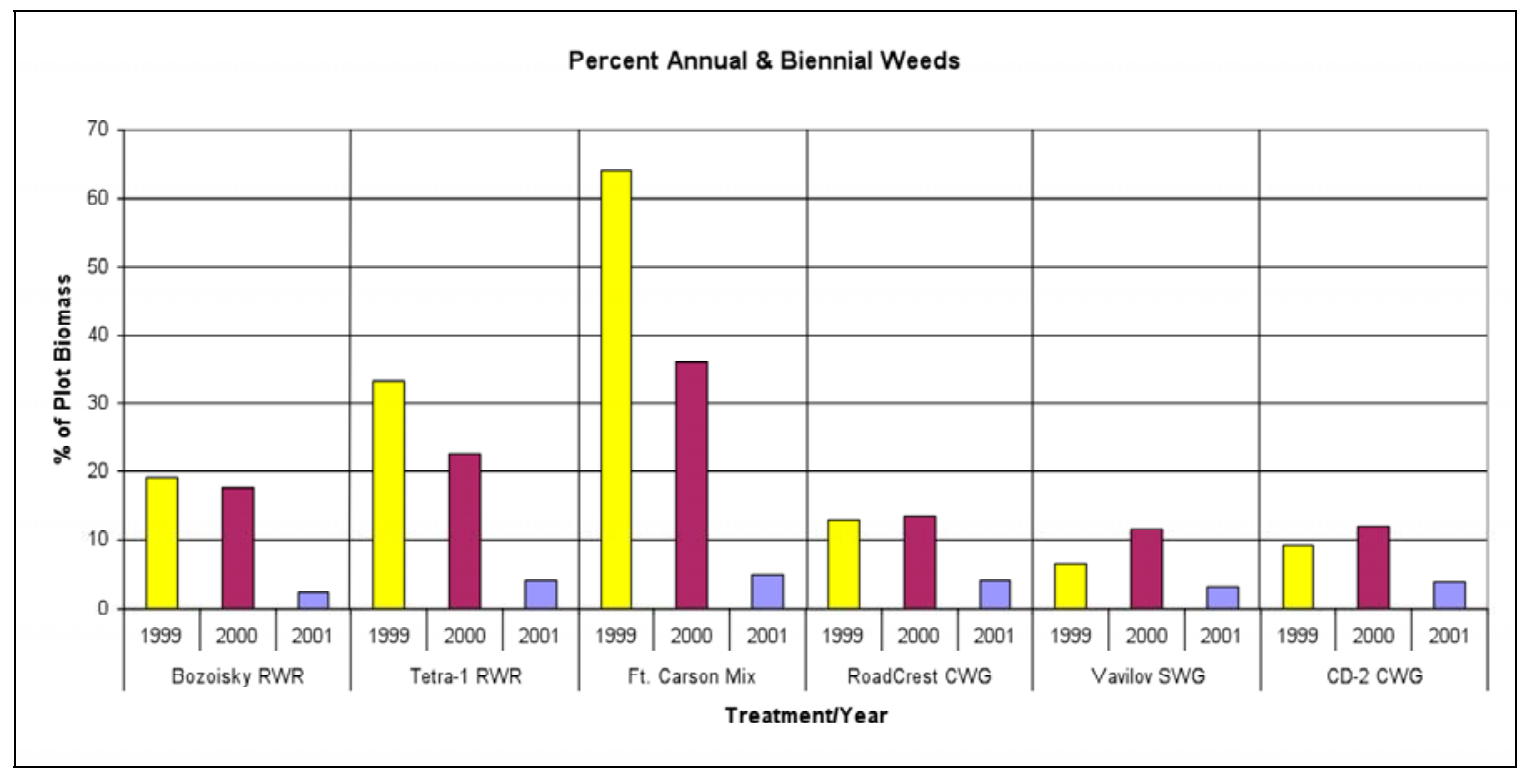

Figure 3. Percent annual and biennial weeds in Turkey Creek plots planted with the standard Fort Carson mix or with a core native mix plus an introduced grass (as named on the treatment axis).

The Fort Carson mix resulted in the greatest number of natives after 3 years, but the natives established more slowly, from about 30\% to $90 \%$ over the 3 years, and the mix produced much less diversity among the natives species (Figure 4) (Palazzo et al. 2003; Waldron et al. 2005). These results suggest that there are several options, depending upon whether the main objective is rapid weed control on an area of frequent disturbance (core mix with crested wheatgrass) or the establishment of a diverse native stand in an area with fewer disturbances (military mix with western wheatgrass or, for greater erosion and weed control, core mix with Russian wildrye). 


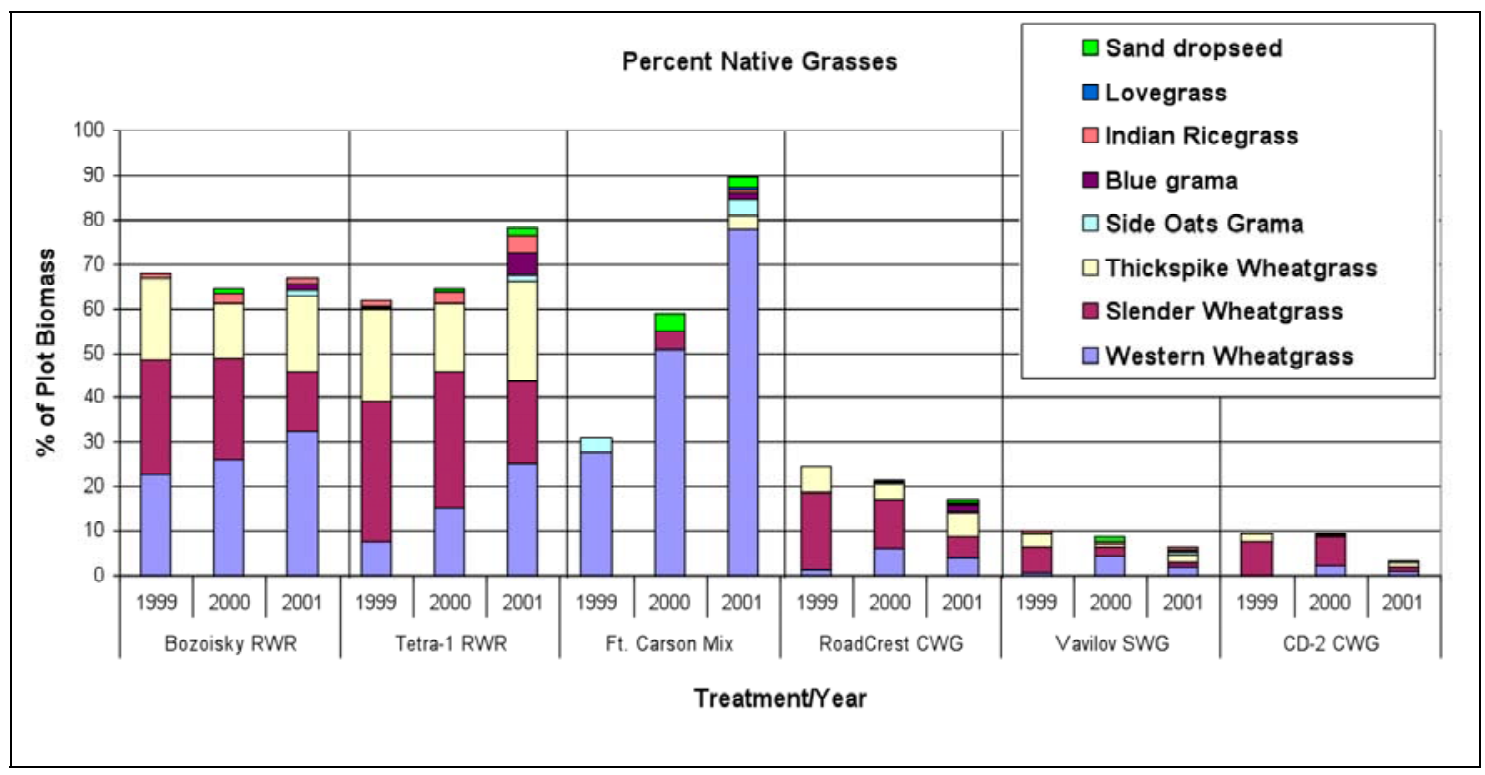

Figure 4. Percent native grasses in Turkey Creek plots planted with the standard Fort Carson mix or with a core native mix plus an introduced grass (as named on the treatment axis).

At Fort Drum, we planted mixed seedings of a nurse crop (weeping lovegrass) and fine fescues with the desired native switchgrass on difficultto-revegetate sandy soils. Weeping lovegrass was not part of our earlier studies of introduced species, but we selected it for initial use as "nurse crop" at Fort Drum because, as a warm-season annual, we expected it to die out after the first season or two.

For treatments, we applied liquid cow manure at rates of $0,22,400$, 44,800 , and $89,600 \mathrm{~kg} / \mathrm{ha}(\mathrm{o}, 10,20$, and 40 tons/acre). The manure slurry provided a mulching effect that prevented drying of the newly established plants, allowing time for them to develop roots long enough to reach into the deeper soil layers. All grass species appeared to grow better where the cow manure was applied, and good soil cover was obtained over the entire area in the initial season, through the strong growth of weeping lovegrass. The weeping lovegrass established quickly at all three rates sown, providing rapid control of wind and water erosion and allowing the land to be opened for training in about 1 year. The seeding provided a vegetative cover of greater than $85 \%$ in the first year with the manure applications, quickly protecting the soil and moisture. Establishment was not as good where manure was not applied, but it eventually established a good cover in the first year. 
As a warm-climate annual, most of the lovegrass died back after the first or second year, allowing the fescues to come in. After 4 years, switchgrass dominated the stand (Figure 5).

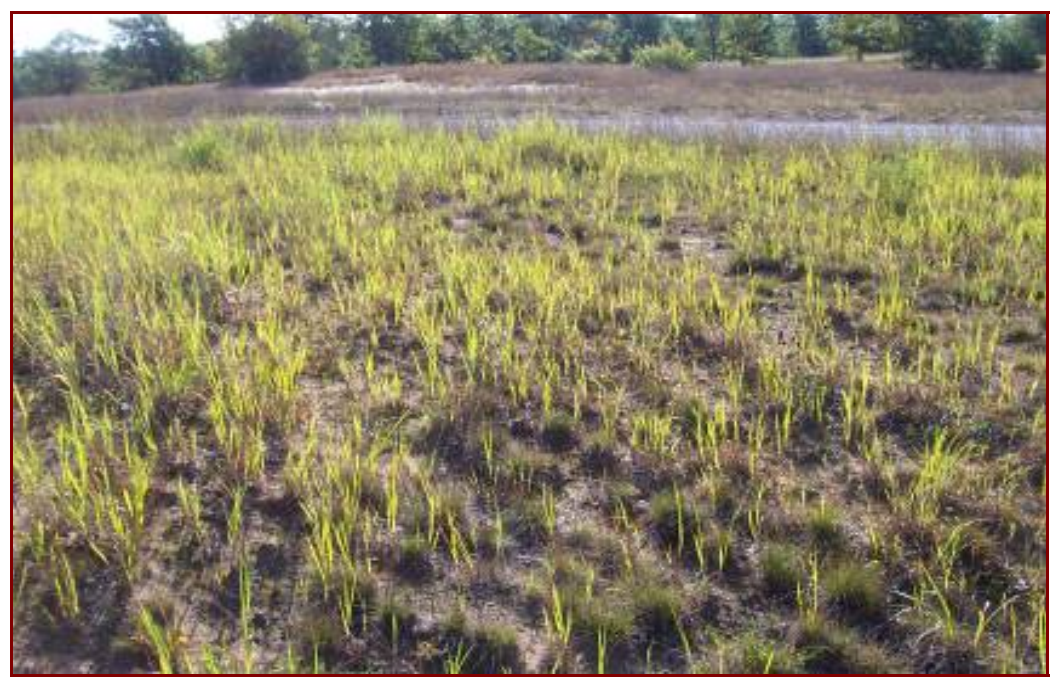

Figure 5. Switchgrass dominating an ecological-bridge plot at Fort Drum, 4 years after seeding.

\subsection{Advantages and limitations of the technology}

With these new germplasms and seeding methods, land managers will be able to more quickly establish grass stands with improved resilience to training activities, and they will better be able to establish healthy native stands while relying less on chemical or mechanical means to control invasive plants (Palazzo et al. 2005). Ranges will therefore be less prone to erosion and be more available to training programs.

The only limitations to the technology beyond availability of the seeds, which this project has helped to overcome, are unusual drought or seasonal extremes, which would affect any plant materials. The modified germplasms have been selected to possess traits that maintain or improve upon a species' current ability to tolerate cool, dry conditions.

The "alternative" technologies that these modified seeds and methods will replace are the currently available seed sources and the current trial-anderror methods of selecting the best seed mixes. 


\section{Performance Objectives}

Our primary performance objectives in this demonstration project were to evaluate the new germplasms developed under the SERDP program and to demonstrate the benefits of the ecological-bridge seeding methods that came from that same program. The evaluation portion of the program allowed us to determine the types of release suitable for the SERDP-select germplasms, to gather appropriate data for those releases, and to enhance our marketing efforts to seed producers and land managers. Table 4 below summarizes our performance objectives as stated in our Demonstration Plan along with the results for each objective. Detailed results are presented in Sections 5.6 and 6. 
Table 4. Performance objectives.

\begin{tabular}{|c|c|c|c|c|}
\hline $\begin{array}{l}\text { Performance } \\
\text { Objective }\end{array}$ & $\begin{array}{l}\text { Metric (Expected } \\
\text { Performance) }\end{array}$ & $\begin{array}{l}\text { Data } \\
\text { Requirements }\end{array}$ & Success Criteria & Results \\
\hline \multicolumn{5}{|l|}{ Quantitative } \\
\hline $\begin{array}{l}\text { Improved } \\
\text { establishment } \\
\text { of SERDP- } \\
\text { select } \\
\text { germplasms } \\
\text { compared to } \\
\text { standard } \\
\text { cultivars } \\
\text { (Section 6.1) }\end{array}$ & $\begin{array}{l}\text { Faster } \\
\text { establishment } \\
\text { rate for modified } \\
\text { germplasms } \\
\text { compared to } \\
\text { standard cultivars }\end{array}$ & $\begin{array}{l}\text { Stand } \\
\text { establishment } \\
\text { rates for SERDP- } \\
\text { select } \\
\text { germplasms and } \\
\text { equivalent } \\
\text { standard cultivars }\end{array}$ & $\begin{array}{l}\text { Will have significantly } \\
(P<0.05) \text { greater } \\
\text { stand establishment } \\
\text { than base population } \\
\text { cultivar after } 1 \text { year }\end{array}$ & $\begin{array}{l}\text { Four cultivars-Bozoisky-II } \\
\text { Russian wildrye, } \\
\text { FirstStrike slender } \\
\text { wheatgrass, Recovery } \\
\text { western wheatgrass, and } \\
\text { Vavilov II Siberian } \\
\text { wheatgrass-had } \\
\text { significantly }(P<0.05) \\
\text { greater stand } \\
\text { establishment than base } \\
\text { population cultivar after } 1 \\
\text { or more years }\end{array}$ \\
\hline $\begin{array}{l}\text { Release new } \\
\text { modified } \\
\text { germplasms } \\
\text { (Section 6.2) }\end{array}$ & $\begin{array}{l}\text { Prepare and } \\
\text { publish six } \\
\text { germplasm } \\
\text { releases } \\
\text { describing new } \\
\text { germplasms }\end{array}$ & $\begin{array}{l}\text { Determine } \\
\text { physiological } \\
\text { characteristics of } \\
\text { SERDP-select } \\
\text { germplasms }\end{array}$ & $\begin{array}{l}\text { Acceptance by AOSCA } \\
\text { (2003) or equivalent } \\
\text { state review board for } \\
\text { certification within } \\
\text { appropriate class } \\
\text { germplasm }\end{array}$ & $\begin{array}{l}\text { Four cultivars and two } \\
\text { pre-variety germplasms } \\
\text { have been released (see } \\
\text { Table 1) }\end{array}$ \\
\hline $\begin{array}{l}\text { Release new } \\
\text { modified } \\
\text { cultivars } \\
\text { (Section 6.3) }\end{array}$ & $\begin{array}{l}\text { Satisfy criteria for } \\
\text { release of two or } \\
\text { more germplasms } \\
\text { as cultivars }\end{array}$ & $\begin{array}{l}\text { Conduct } \\
\text { evaluations to } \\
\text { compare } \\
\text { establishment, } \\
\text { persistence, } \\
\text { rhizome } \\
\text { development, etc., } \\
\text { differences } \\
\text { between SERDP- } \\
\text { select and } \\
\text { standard cultivars. }\end{array}$ & $\begin{array}{l}\text { Satisfy necessary } \\
\text { criteria for application } \\
\text { to USDA as a PVP } \\
\text { cultivar (actual } \\
\text { acceptance can take } \\
5-7 \text { years after } \\
\text { application) }\end{array}$ & $\begin{array}{l}\text { Four cultivars have been } \\
\text { released under ESTCP: } \\
\text { Vavilov II Siberian } \\
\text { wheatgrass, FirstStrike } \\
\text { slender wheatgrass, } \\
\text { Recovery western } \\
\text { wheatgrass, and Bozoisky } \\
\text { II Russian wildrye. We } \\
\text { have the potential for one } \\
\text { more cultivar release (see } \\
\text { Table 1) }\end{array}$ \\
\hline $\begin{array}{l}\text { Improved } \\
\text { resilience of } \\
\text { grasses to } \\
\text { military traffic } \\
\text { (Section 6.4) }\end{array}$ & $\begin{array}{l}\text { Increased } \\
\text { resiliency of new } \\
\text { germplasms to } \\
\text { military traffic } \\
\text { compared to } \\
\text { varieties currently } \\
\text { in use }\end{array}$ & $\begin{array}{l}\text { 1. Conduct } \\
\text { tracking } \\
\text { experiments on } \\
\text { established } \\
\text { stands } \\
\text { 2. Evaluate plant } \\
\text { stands after } 1 \\
\text { year. }\end{array}$ & $\begin{array}{l}\text { Significantly }(\mathrm{P}<0.05) \\
\text { better stands in new } \\
\text { germplasms } 1 \text { year } \\
\text { after tracking as } \\
\text { compared to } \\
\text { standard varieties }\end{array}$ & $\begin{array}{l}\text { Three new cultivars- } \\
\text { Bozoisky II Russian } \\
\text { wildrye, Vavilov II Siberian } \\
\text { wheatgrass, and SERDP- } \\
\text { select Snake River } \\
\text { wheatgrass-did } \\
\text { significantly better than } \\
\text { the commonly available } \\
\text { varieties for all } \\
\text { treatments. }\end{array}$ \\
\hline $\begin{array}{l}\text { Improved } \\
\text { establishment } \\
\text { of native grass } \\
\text { stands } \\
\text { (Section 6.5) }\end{array}$ & $\begin{array}{l}\text { Greater } \\
\text { establishment of } \\
\text { natives in } \\
\text { ecological-bridge } \\
\text { seedings } \\
\text { compared to } \\
\text { standard mixes }\end{array}$ & $\begin{array}{l}\text { Evaluate mixed } \\
\text { seedings on at } \\
\text { least two different } \\
\text { sites. }\end{array}$ & $\begin{array}{l}\text { Obtain a grass stand } \\
\text { of native plants } 4 \\
\text { years after planting }\end{array}$ & $\begin{array}{l}\text { Accomplished at Fort } \\
\text { Drum; all mixes at } \\
\text { Guernsey established } \\
\text { more rapidly and } \\
\text { persisted better than the } \\
\text { standard Guernsey mix } \\
\text { (drought prevented } \\
\text { evaluation for } 4 \text { years) }\end{array}$ \\
\hline
\end{tabular}




\begin{tabular}{|c|c|c|c|c|}
\hline $\begin{array}{l}\text { Performance } \\
\text { Objective }\end{array}$ & $\begin{array}{l}\text { Metric (Expected } \\
\text { Performance) }\end{array}$ & $\begin{array}{l}\text { Data } \\
\text { Requirements }\end{array}$ & Success Criteria & Results \\
\hline $\begin{array}{l}\text { Reduce weeds } \\
\text { in grasses on } \\
\text { training lands } \\
\text { (Section 6.6) }\end{array}$ & $\begin{array}{l}\text { Reduced stands } \\
\text { of noxious weeds } \\
\text { in ecological- } \\
\text { bridge seeding } \\
\text { mixes compared } \\
\text { to mixes currently } \\
\text { in use or natives } \\
\text { sown alone }\end{array}$ & $\begin{array}{l}\text { Evaluate } \\
\text { percentage of } \\
\text { weeds in stands } \\
\text { sown with } \\
\text { ecological-bridge } \\
\text { mixes, standard } \\
\text { mixes, and natives } \\
\text { sown alone }\end{array}$ & $\begin{array}{l}\text { Significant }(P<0.05) \\
\text { reduction of weeds in } \\
\text { ecological-bridge } \\
\text { stands as compared } \\
\text { to natives sown alone } \\
\text { after } 2 \text { years }\end{array}$ & $\begin{array}{l}\text { No significant differences } \\
\text { at YTC or Guernsey, } \\
\text { although the highest } \\
\text { percent weeds were } \\
\text { found with the all native } \\
\text { mix } 2 \text { and core native mix } \\
4 \text { at the Guernsey River } \\
\text { site after } 2 \text { years. }\end{array}$ \\
\hline \multicolumn{5}{|c|}{ Qualitative (Section 6.7) } \\
\hline Reliability & $\begin{array}{l}\text { Ability to } \\
\text { withstand } \\
\text { environmental } \\
\text { conditions as well } \\
\text { as or better than } \\
\text { existing cultivars }\end{array}$ & $\begin{array}{l}\text { Observations and } \\
\text { data evaluation } \\
\text { during } \\
\text { demonstration }\end{array}$ & $\begin{array}{l}\text { Planting in several } \\
\text { different climatic } \\
\text { locations }\end{array}$ & $\begin{array}{l}\text { We have successfully } \\
\text { established our modified } \\
\text { germplasms at four } \\
\text { facilities in two climatic } \\
\text { areas within the 4-year } \\
\text { time frame of this } \\
\text { demonstration. }\end{array}$ \\
\hline Ease of Use & $\begin{array}{l}\text { No additional } \\
\text { personnel or } \\
\text { equipment } \\
\text { required }\end{array}$ & $\begin{array}{l}\text { Experience during } \\
\text { demonstrations }\end{array}$ & $\begin{array}{l}\text { No increase in time or } \\
\text { cost required for soil } \\
\text { preparation and } \\
\text { seeding }\end{array}$ & $\begin{array}{l}\text { Most operations can be } \\
\text { completed with a single } \\
\text { tractor pass; no new } \\
\text { methods or equipment } \\
\text { are required. }\end{array}$ \\
\hline Versatility & $\begin{array}{l}\text { Comparable } \\
\text { results at two or } \\
\text { more test sites }\end{array}$ & $\begin{array}{l}\text { Evaluations of } \\
\text { plant stands at } \\
\text { two or more sites }\end{array}$ & $\begin{array}{l}\text { Observation of } \\
\text { improved } \\
\text { performance at } \\
\text { multiple sites }\end{array}$ & $\begin{array}{l}\text { Modified germplasms } \\
\text { were successful on } \\
\text { different soils and } \\
\text { climatic areas. }\end{array}$ \\
\hline Maintenance & $\begin{array}{l}\text { No need to } \\
\text { reseed, fertilize, } \\
\text { or mow }\end{array}$ & $\begin{array}{l}\text { Evaluations during } \\
2-3 \text { years after } \\
\text { planting }\end{array}$ & $\begin{array}{l}\text { Experience during } \\
\text { demonstrations }\end{array}$ & $\begin{array}{l}\text { Plants required no } \\
\text { maintenance after } \\
\text { seeding; plant stands } \\
\text { continued to thrive } \\
\text { throughout the } \\
\text { demonstration. }\end{array}$ \\
\hline \multirow[t]{2}{*}{$\begin{array}{l}\text { Scale-up } \\
\text { Constraints }\end{array}$} & $\begin{array}{l}\text { 1. Availability of } \\
\text { seed }\end{array}$ & $\begin{array}{l}\text { b. Contract with } \\
\text { seed producers }\end{array}$ & $\begin{array}{l}\text { Seed available from } \\
\text { seed producers }\end{array}$ & $\begin{array}{l}\text { a. Seed of three grasses } \\
\text { was distributed to eight } \\
\text { military facilities in the } \\
\text { Intermountain West over } \\
2 \text { years. } \\
\text { b. We have established } \\
\text { one commercial seed } \\
\text { contract }\end{array}$ \\
\hline & $\begin{array}{l}\text { 2. Awareness of } \\
\text { seed capabilities } \\
\text { and appropriate } \\
\text { planting methods }\end{array}$ & $\begin{array}{l}\text { a. Prepare } \\
\text { releases } \\
\text { b. Prepare } \\
\text { planting guide }\end{array}$ & $\begin{array}{l}\text { Publish releases and } \\
\text { planting guide; widely } \\
\text { distribute planting } \\
\text { guide }\end{array}$ & $\begin{array}{l}\text { a. Six new releases have } \\
\text { been published under } \\
\text { ESTCP } \\
\text { b. The Planting Guide has } \\
\text { been published. }\end{array}$ \\
\hline
\end{tabular}




\section{Site Description}

The criteria for selecting our locations were their importance to the military mission and the degree to which their climates represent other DoD installations. We considered test sites in two climatic areas: the Intermountain West and the Northeast for the ecological bridge studies, and in the Intermountain West for our plant development research (Figure 6). Sites in these climatic areas had a diversity of landscapes in terms of soil thickness, microclimates, and terrain to support the need for multiple germplasm species grown in mixtures. The Intermountain West test sites also contain a diversity of microclimatic areas that contain a greater diversity of plant species than a single location. We also wanted to demonstrate the germplasms and seed mixtures on military lands that could potentially be subjected to military vehicle traffic as part of the validation testing. Yakima Training Center (YTC), Yakima, Washington; Fort Drum, New York; Camp Guernsey, Guernsey, Wyoming; and Dugway Proving Ground, Dugway, Utah, met these criteria, and they provided strong financial and personnel support.

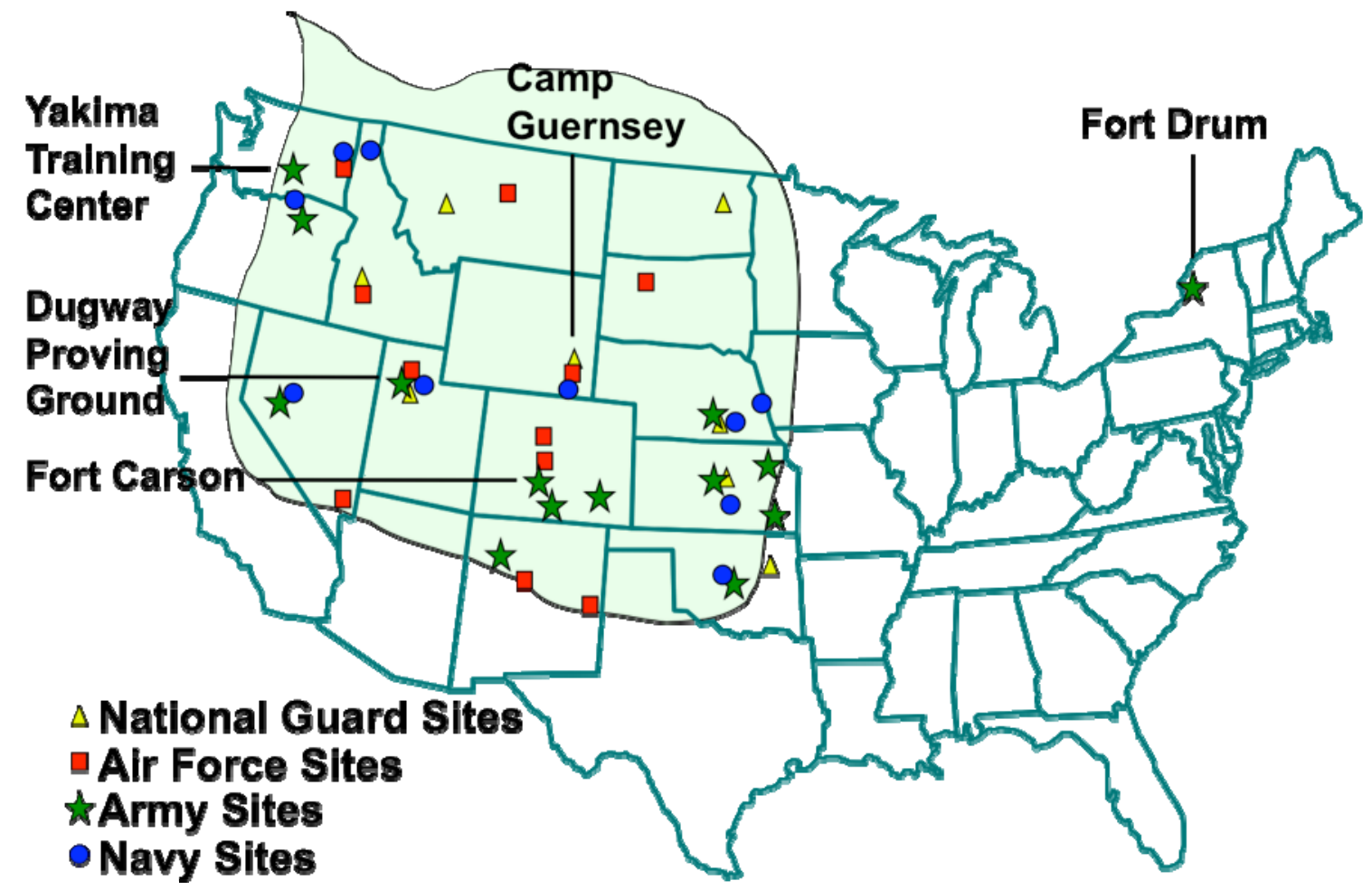

Figure 6. The general range of distribution for SERDP-select germplasms, showing locations of the main demonstration sites and other military facilities in the Intermountain West as they existed at the beginning of this study. 
The comparative field evaluations of new germplasms with existing cultivars were conducted at Camp Guernsey, YTC, and Dugway Proving Ground. The demonstrations of ecological-bridge seed mixtures took place at Camp Guernsey, YTC and Fort Drum. Earlier studies on our developing germplasms and ecological-bridge mixtures were performed at Fort Carson; our work at Fort Carson provided the basis for our cost analyses.

In addition to the larger demonstration studies, we conducted further tests for cultivar validation at the ERDC-CRREL greenhouse and at several nursery-field sites (Table 8). These additional locations are described in Section 5.3.4.

\subsection{Site location and history}

Yakima Training Center (YTC) is an Army facility in south-central Washington (Figure 6). We had done revegetation at YTC before and during our SERDP breeding program, and we used YTC for the tracked vehicle studies under the SERDP project (Palazzo et al. 2005). The area we used in this demonstration was Exit 11, which is in the northwest corner of the facility and is typically used for training with tracked or wheeled vehicles.

Camp Guernsey is a 17,070-ha (42,180-acre) Wyoming Army National Guard (WYARNG) military training area in southeastern Wyoming along the North Platte River (Figure 6). Camp Guernsey is the primary training area for WYARNG, with heaviest use occurring during the summer months. Training exercises conducted at Camp Guernsey include firing small arms (individual and crew-served weapons), artillery, and mortar; tactical and administrative bivouacs; engineer training; and bridging and river-crossing operations. Emphasis is on training field artillery units; however, training facilities and ranges are available for infantry, engineer, aviation, maintenance, and medical units. Other common training exercises conducted at Camp Guernsey include map exercises, tactical exercises without troops, command post exercises, situational training, field training, live fire, and lanes training. We used two sites: the River site, southeast of the cantonment adjacent to the North Platte River, and the Tower site, north of the cantonment near the radar tower. These two sites are primarily used for training with tracked and wheeled vehicles. 
Dugway Proving Ground (DPG) is located in the Great Salt Lake Desert, approximately 85 miles southwest of Salt Lake City, Utah, within the eastern Great Basin, specifically the Bonneville Basin (Figure 6). The DoD has designated the 398,542-ha (798,855-acre) DPG as a Major Range Test Facility Base (MRTFB) and the primary chemical and biological defense testing center under the Reliance Program. Testers here determine the reliability and survivability of all types of military equipment in chemical or biological environments. The primary mission of DPG is to plan, conduct, analyze, and report the results of exploratory, developmental, and production tests of chemical and biological defense systems, and smoke and obscurant illumination material and delivery systems. The demonstration site was located at the highest elevation of the eastern part of the facility.

Fort Drum is located just east of Lake Ontario in upstate New York (Figure 6) and is under the command of the U.S. Army Commands (ACOM), formerly FORSCOM. The primary mission of Fort Drum is to provide facilities and services to U.S. Armed Forces that require land and airspace to practice combat skills and operations year-round. Fort Drum is also home to the $10^{\text {th }}$ Mountain Division (Light Infantry) whose mission is to deploy rapidly anywhere in the world and be prepared to fight and win upon arrival. The $10^{\text {th }}$ Mountain Division Light Infantry consists of light infantry brigades, an aviation brigade, a division artillery brigade, a division support command brigade, an engineer battalion, a signal battalion, an intelligence battalion, an air defense battalion, a military police battalion (provisional), a division band, and a headquarters company.

At Fort Drum, we used two study sites in the western part of the facility: training Area 8, about 5 miles north of the cantonment, and the Airport site, adjacent to the cantonment. The Airport site is a restricted area not used for training; Area 8 has been used for defilades (deep trenches).

Fort Carson is a U.S. Army Commands (ACOM) facility in south-central Colorado, south of Colorado Springs at 1,920 m (6,300 ft) elevation (Figure 6). The military mission of Fort Carson is to train, mobilize, deploy, and sustain combat-ready, multi-component integrated forces. Fort Carson provides facilities and service to U.S. Armed Forces that require land and airspace to practice combat skills and operations on a year-round basis. In our SERDP breeding program, we used the Turkey 
Creek area near the northwest corner of the facility $\left(38^{\circ} 37^{\prime} 20^{\prime \prime} \mathrm{N}, 104^{\circ}\right.$ $52^{\prime} 4 \mathrm{O}^{\mathrm{\prime}} \mathrm{W}$ ). Our fenced study site was tilled to a depth of $20 \mathrm{~cm}$ (7.9 in.) to imitate disturbance and reduce existing weeds in spring 1997. Areas near the study site are regularly seeded with the military seed mix after disturbance by tracked vehicles during training exercises. We compared data from this study along with existing costs at Fort Carson to develop our cost savings information (see Section 7).

\subsection{Site characteristics}

Yakima Training Center encompasses an area over 130,00o ha (321,237 acres) in the Columbia basin of south-central Washington. The YTC region is part of the shrub-steppe, the largest of the grassland regions in North America (Rogers and Rickard 1998). YTC soils are typically loess overlying basalt, and the climate is characterized as semiarid, temperate, and continental with cold, wet winters and hot, dry summers (Jones and Bagley 1997). The region receives less than $25 \mathrm{~cm}$ (10 in.) of average annual precipitation. However, altitude plays a major role in site-specific annual precipitation. YTC sites about $455 \mathrm{~m}(1500 \mathrm{ft})$ altitude receive about $20.3 \mathrm{~cm}$ ( $8 \mathrm{in}$.), while sites near $910 \mathrm{~m}$ (3000 ft) altitude have lower temperatures and receive $30.5 \mathrm{~cm}$ (12 in.).

The YTC soils and vegetation are typical for central Washington state: shrub-steppe consisting of deep, silty, clay-loam soils (Drysel, MelozaRoza; fine, montmorillonitic, mesic Xeric Camborthids) on a $0-3 \%$ slope; and dominated by big sagebrush (Artemisia tridentata) (Daubenmire 1970; Jones and Bagley 1997). The dominant vegetation is perennial bunchgrass such as bluebunch wheatgrass (Elytrigia spicata) or Poa secunda.

The climate at Camp Guernsey is considered semiarid with a total annual precipitation of $33-35 \mathrm{~cm}$ (13 in.). Peak precipitation occurs during May and June. Average daily temperatures range from $-1{ }^{\circ} \mathrm{C}$ in the winter to $21^{\circ} \mathrm{C}$ in the summer. The soils can be broken up into three areas: cantonment, north training area, and south training area. Soils in the south training area are shallow to moderately deep loamy and sandy with many areas of rock outcrops; slopes are moderately steep to steep. In the north training area soils are deep to moderately deep silty and loamy with gentle to moderately steep rolling hills (Warren et al. 2000). Our two sites are high plains, moderate relief rangeland. The River site is in the south training area near the North Platte River (N 42 ${ }^{\circ} 15.001^{\prime}$ W 104 ${ }^{\circ} 44.090^{\prime}$; 
elevation $1320 \mathrm{~m}$ [ $4330 \mathrm{ft}$ ]) and has very dry, sandy soil. The Tower site is in the north training area near the Guernsey Radar Tower ( $\mathrm{N} 42^{\circ} 14.385^{\prime}$ W 104 ${ }^{\circ}$ 44.302'; elevation $1393 \mathrm{~m}$ [4570 ft]) and has silty soil. These two sites are representative of the warm- and cool-season grass transition zone where western wheatgrass is often a dominant species.

Surrounded on three sides by mountain ranges, the Dugway Proving Ground's terrain varies from level salt flats to scattered sand dunes and rugged mountains. DPG is in the Great Salt Lake Basin where there is a great variability in precipitation patterns. On average, the area receives $19 \mathrm{~cm}(7.5$ in.) of annual precipitation, but the lowest and highest amounts were 8.5 cm (3.32 in.) in 1966 and $38 \mathrm{~cm}$ (14.99 in.) in 1982. The average daily temperatures range from $-2.5{ }^{\circ} \mathrm{C}$ in winter to $24.3{ }^{\circ} \mathrm{C}$ in summer, but it can reach $40^{\circ} \mathrm{C}$. The aridity of the area is caused by the rain shadows cast by the High Sierra Mountains of California and Nevada, and to a lesser extent by the Deep Creek, Pilot, and Snake Ranges of western Utah and eastern Nevada. The demonstration site was north of English Village where the soils are a fine sand, with $2-15 \%$ slopes. The main topographic features of DPG area are rugged, fault block mountains, generally running from north to south, with fairly level, intervening valleys. The Cedar Mountains, which are an example of this type of mountain range, form the northeastern boundary of the installation, terminating just north of English Village. The peak elevation of the Cedar Mountains is 2,340 m (7,700 ft), which is outside of the DPG boundary. (U. S. Army 2005.)

Fort Drum encompasses two major physiographic provinces, the Lake Erie-Ontario Lowlands and the Adirondack Uplands. The southwestern two-thirds of the installation, where the Airport and Area 8 sites are located, are part of the Lake Erie-Ontario Lowlands division. In this area, surface geological features are recessional moraines, small sand plains, drumlins, swamps, and drainage patterns resulting from Pleistocene glaciation. The geology at Fort Drum is underlain by a variety of metamorphic, igneous, and sedimentary bedrock ranging from Precambrian to Middle Ordovician. The oldest metamorphic rocks belong to the Grenville Complex and consist mainly of metamorphosed Precambrian quartzite, gneiss, schist, and marble. These rocks stretch in a wide northeast-southwest band across Fort Drum and border the igneous Adirondack massif and associated foothills to the east. 
Fort Drum soils are generally developed from deltaic/lacustrine or glacial deposits. The soils vary from sandy gravels to loams to clays to mucks. Soils in the region are generally shallow and poorly drained; soil permeability is slow to moderate. The two study sites at Fort Drum are located on a Plainfield sandy soil and contained a mean of $92 \%$ sand, with small amounts of silt and clay. Both sites are on relatively level open areas with less than $25 \%$ tree canopy, and the areas were wind blown and mostly devoid of vegetation at the beginning of the study. Grasslands and meadows on sandy soils at Fort Drum are dominated by common hairgrass, stiff-leaved aster, poverty oat grass, and the sedge Carex lucorum. Grasslands on sandy soils are visually distinct from corresponding communities on less sandy soils, showing a relatively species-poor vegetative diversity with a predominance of native species.

Fort Drum has a primarily humid, continental climate with relatively long, cold winters and short, warm and often humid summers. The mean annual temperature, averaged over the past 10 years, is $8.9^{\circ} \mathrm{C}\left(48^{\circ} \mathrm{F}\right)$. January is the coldest month, closely followed by February and December. Temperatures fall below $-18{ }^{\circ} \mathrm{C}\left(\mathrm{O}^{\circ} \mathrm{F}\right)$ on about 20 days during these 3 months; below-freezing temperatures occur on about 104 days from December to March. (U.S. Army 2001)

The Fort Carson research site at the Turkey Creek Recreation Area has soils that are a fine sandy loam (mixed, calcareous mesic Ustic Torriorhents). The 22-year mean annual precipitation for Colorado Springs is $38.3 \mathrm{~cm}$ ( $15 \mathrm{in}$.), with approximately $80 \%$ of this precipitation received from April to September. This site contains vegetation typical of the Great Plains steppe provinces (Bailey 1995). Shrubs are rare, but oneseed juniper (J uniperus monosperma [Engelm.] Sarg.) has encroached into grasslands during the last century. Dominant grass species include western wheatgrass, blue grama (Bouteloua gracilis [H.B.K.] Lag. ex Steudel), and sideoats grama (B. curtipendula [Michx.] Torr.). Subdominant grasses include green needlegrass [Nassella viridula (Trin.) Barkworth] and needle and thread grass (Stipa comata Trim \& Rupr.). 


\section{Test Design}

\subsection{Conceptual test design}

Demonstration activities included: (1) comparative field evaluations of new germplasms with existing cultivars, (2) evaluations of ecologicalbridge mixes vs. standard mixes, (3) traffic tests on established plots, and (4) germination and nursery-field studies to further validate cultivars for release.

The comparative field evaluations of new germplasms with existing cultivars were conducted at Camp Guernsey, YTC, and DPG. The demonstrations of ecological-bridge seed mixtures took place at Camp Guernsey, YTC, and Fort Drum. Traffic studies on germplasms and mixes were conducted at YTC. Additional studies to validate germplasms for release were conducted at the ERDC-CRREL greenhouse and several USDA-ARS nursery-field sites.

At least six SERDP-select germplasms were tested at Guernsey, YTC, and DPG, along with a corresponding existing cultivar for each. The exact number of germplasms varied at each site, depending on seed availability and appropriateness to climate and soil conditions. In addition, two seed mixes were tested at one YTC location, and seven mixes were tested at two locations at Camp Guernsey. At Fort Drum, eight mixes were tested in two locations.

Three to four replicates were used for each seeding, with individual plots ranging in size from 18 to $36 \mathrm{~m}^{2}$. Seeds were sown at a rate of approximately one seed per $\mathrm{cm}$ ( 2.5 seeds per linear inch). Plots at all sites were monitored yearly and measured for stand establishment or percentage of sown species, other plant species, weeds, and bare ground. Details of plantings and monitoring schedules are provided in the following sections.

\subsection{Baseline characterization and preparation}

The demonstration seeding sites at YTC and Camp Guernsey were in areas previously used for training. They were prepared by rototilling in the spring before planting, followed by summer applications of Roundup ${ }^{\circledR}$ for non- 
selective removal of existing vegetation and Trimec ${ }^{\circledR}\left(2,4^{-}\right.$ dichlorophenoxyacetic acid [2,4-D]) for control of broad-leaf weeds; YTC sites received one spraying of the chemicals and Guernsey sites received three. Seeds were planted that fall at YTC (2002) and the following spring at Guernsey (2004 for the River site and 2005 for the Tower site) using a cone seeder equipped with double-disk furrow openers and depth band regulators (also called a no-till seeder).

At DPG we used disturbed bare land, so no preparation other than rototilling was needed. The site was tilled in the summer of 2005 and seeded that fall.

At Fort Drum, both research sites were relatively level and the areas were wind blown and devoid of vegetation at the beginning of both studies (May 2002). We first broadcast an application of 10-10-10 grade fertilizer at a rate of need of $0.72 \mathrm{t} / \mathrm{ha}(65 \mathrm{Ob} /$ acre $)$. We next applied dolomitic limestone by broadcast at a rate of $0.91 \mathrm{t} / \mathrm{ha}(2,000 \mathrm{lb} / \mathrm{acre})$. After application of soil amendments, the sites were divided into the respective study plots, and the seeds were sown with a Great Plains no-till seeder. The Area 8 site has previously been used for defilade training (trenches); the Airport site is in a restricted area not used for training.

No mobilization or installation was required at any facility other than travel of research personnel to the sites. There was no special equipment to be maintained, nor were there any hazardous wastes involved.

\subsection{Design and layout of technology components}

As noted above, demonstration activities included: (1) comparative field evaluations of new germplasms with existing cultivars, (2) evaluations of ecological-bridge mixes vs. standard mixes, (3) traffic tests on established plots, and (4) germination and nursery-field studies to further validate germplasms for release. These evaluations allowed us to confirm the types of releases suitable for the SERDP-select germplasms, gather appropriate data for those releases, and enhance our marketing efforts to seed producers and land managers.

Except as noted below, the demonstrations were similar at the selected sites. The setup details for each activity are given below; Section 5.4 gives the measurements taken at each site. 


\subsubsection{Field evaluations of new germplasms: comparisons of germplasms with existing cultivars (monocultures) - design}

We seeded the monoculture evaluation plots at YTC, Camp Guernsey, and DPG to provide the required testing for release of any new cultivars and to demonstrate the potential superiority of the new germplasms compared to currently available cultivars. These studies provided data and a showcase for our marketing efforts, and allowed us to determine which SERDPselect germplasms would meet certification requirements for cultivars.

The Exit 11 site at YTC was seeded 21-22 October 2002. A second site (the River site) was seeded in spring 2004 at Camp Guernsey, and a third site (the Tower site) was seeded at Guernsey in Spring 2005. A site was seeded at DPG in fall 2005.

The trials were planted with a cone seeder equipped with double-disk furrow openers and depth band regulators. This seeder allows the comparison of entries with limited seed. Individual plots consisted of six drilled rows spaced $25 \mathrm{~cm}$ apart. Plot sizes were $1.5 \times 24 \mathrm{~m}(5 \times 8 \mathrm{ft})$ at YTC and $1.5 \times 6 \mathrm{~m}(5 \times 20 \mathrm{ft})$ at Guernsey and DPG. Seeds were placed $1.25-2.0 \mathrm{~cm}$ below the soil surface approximately $1 \mathrm{seed} / \mathrm{cm}$ (2.5 seeds per linear inch). Plots were arranged in randomized complete blocks with three or four replications at each site. The plants were not irrigated or fertilized; they were allowed to grow naturally in the local climate and soils. At YTC, the plots were subjected to military traffic after the plants are fully established (see Section 5.3.3 on military traffic).

The monoculture evaluations compared each of seven SERDP-select germplasms (four native and two introduced grasses plus one native forb, yarrow) with at least one standard cultivar. Additional species and varieties were planted in some locations; the lists below show only those of interest to this demonstration. (The native germplasms are given first, with the name of the standard cultivar used in all trials in parentheses.)

- Bluebunch wheatgrass, Pseudoroegneria spicata (Pursh) A. Löve (Goldar)

- Western wheatgrass, Pascopyrum smithii (Rydb.) Á. Löve (Rosana)

- Snake River wheatgrass, Elymus wawawaiensis J. Carlson \& Barkworth (Secar)

- Slender wheatgrass, Elymus trachycaulus (Link) Gould ex Shinners (Pryor) 
- Western yarrow, Achillea millefolium L. (commercial variety)

- Basin wildrye, Leymus cinereus (Trailhead)

- Sandberg bluegrass, Poa secunda (J. Presl), (common variety).

The introduced entries were as follows. The Syn A Russian wildrye line was developed prior to the initiation of the SERDP breeding program. Syn A was not released, but was used in the development of a subsequent cultivar, Bozoisky II, and is referred to as Bozoisky II parent in the summary tables in these sections. An additional Russian wildrye germplasm, Tetra 1 (Jensen et al. 1998), and two crested wheatgrasses, CD-II and RoadCrest (Asay et al. 1997, 1999), were released during the SERDP program and are used in many of the demonstration seedings (not listed below).

- Russian wildrye (Syn A), Psathyrostachys juncea [Fisch.] Nevski (Bozoisky-Select)

- Siberian wheatgrass, Agropyron fragile(Roth) Candargy (Vavilov)

Yakima Training Center, Exit 11. Monocultures and mixtures were seeded on 21-22 October 2002. Plots are 1.5 x $24 \mathrm{~m}$ ( 5 x $80 \mathrm{ft}$ ) with six rows at $25 \mathrm{~cm}$ (10 in.) apart. There were 9-m wide borders of Hycrest crested wheatgrass between replications. A detailed planting list by replications is given in Appendix Section D.2.

Camp Guernsey, River Site. Monocultures and mixtures were planted on 31 March 2004, with a plot size of $1.5 \times 6 \mathrm{~m}(5 \times 20 \mathrm{ft})$ with six rows at $25 \mathrm{~cm}$ (10 in.) apart. There were $1.5-\mathrm{m}$ ( 5 - $\mathrm{ft}$ ) borders of CD-II crested wheatgrass between replications. A detailed planting list by replications is given in Appendix Section D.3.

Camp Guernsey, Tower Site. Monocultures and mixtures were planted 23 March 2005, with a plot size of $1.5 \times 6 \mathrm{~m}(5 \times 20 \mathrm{ft})$ with six rows at 25 $\mathrm{cm}$ (10 in.) apart. There were $1.5-\mathrm{m}(5-\mathrm{ft})$ borders of CD-II crested wheatgrass between replications. A detailed planting list by replications is given in Appendix Section D.3.

Dugway Proving Ground. This site was seeded with monocultures on 7 November 2005 with a plot size of $1.5 \times 6 \mathrm{~m}(5 \mathrm{ft}$ by $20 \mathrm{ft})$ and a border of CD-II crested wheatgrass around the plots. A detailed planting list by replications is given in Appendix Section D.4. 


\subsubsection{Ecological-bridge demonstration (mixtures) - design}

We evaluated mixtures at YTC, Camp Guernsey, and Fort Drum. Plots at YTC and Camp Guernsey were prepared and seeded with the monocultures as described above for germplasm evaluations in fall 2002 at YTC, and spring 2004 and 2005 at Camp Guernsey (see Sections 5.2 and 5.3.1). The two Fort Drum sites were prepared as described in Section 5.2 and seeded in 2002.

The same set of two mixtures was evaluated at both YTC and Guernsey. One set was an all-native mix and the second was an ecological-bridge mix containing both natives and selected introduced species (Table 5). At Camp Guernsey, an additional set of mixtures was evaluated (Table 6) with duplicate seedings at the two sites; these mixtures tested various ecological bridge combinations and compared them to the all-native mix in use at Camp Guernsey. The mixtures were planted as entries among the monoculture seedings at YTC and Camp Guernsey (see Appendix Sections D.2 and D.3 for planting lists by replication at each site).

Table 5. Seed mixtures planted at both YTC (Exit 11 sown in October 2002) and Camp Guernsey (River site, March 2004; Tower site, March 2005).

\begin{tabular}{|lclc|}
\hline \multicolumn{1}{|c}{ Mix 1: Introduced/native } & $\begin{array}{c}\text { Seeding rate } \\
\text { (lb/acre) }\end{array}$ & \multicolumn{1}{c}{ Mix 2: All native } & $\begin{array}{c}\text { Seeding rate } \\
\text { (lb/acre) }\end{array}$ \\
\hline Western wheatgrass (SERDP) & 4 & Bluebunch wheatgrass (Goldar) & 5 \\
Russian wildrye (Bozoisky) (I) & 3 & Snake River wheatgrass (SERDP) & 5 \\
Siberian wheatgrass (SERDP) (I) & 3 & Western wheatgrass (SERDP) & 5 \\
Bluebunch wheatgrass (Goldar) & 3 & Western yarrow (SERDP) & 0.1 \\
Snake River wheatgrass (SERDP) & 3 & $\begin{array}{l}\text { Sandberg bluegrass (common } \\
\text { variety) }\end{array}$ & 0.3 \\
Western yarrow (SERDP) & 0.1 & & \\
Forage kochia (I) & 0.5 & & \\
Sandberg bluegrass (common & 0.3 & & \\
variety) & & & \\
\hline
\end{tabular}


Table 6. Additional mixtures sown at Camp Guernsey in March 2004 (River site) and March 2005 (Tower site)

\begin{tabular}{|c|c|c|c|c|c|}
\hline Mix & Native & $\begin{array}{c}\text { \% Seeds/ } \\
\text { plot* }\end{array}$ & Introduced & $\begin{array}{c}\text { \% Seeds/ } \\
\text { plot }\end{array}$ & $\begin{array}{l}\text { Purpose / } \\
\text { change }\end{array}$ \\
\hline \multirow{5}{*}{$\begin{array}{l}3 . \\
\text { Current } \\
\text { Guernsey } \\
\text { mix }\end{array}$} & Little bluestem (Camper) & 18 & \multirow[t]{5}{*}{ None } & & \multirow{5}{*}{$\begin{array}{l}\text { Current } \\
\text { Guernsey mix } \\
\text { for comparisor } \\
\text { with our } \\
\text { proposed } \\
\text { changes } \\
(4-7)\end{array}$} \\
\hline & Bluegramma (Lovington) & 59 & & & \\
\hline & Buffalograss (Texoka) & 4 & & & \\
\hline & Western wheatgrass (Rodan) & 8 & & & \\
\hline & Thickspike wheatgrass (Critana) & 11 & & & \\
\hline \multirow{5}{*}{$\begin{array}{l}4 . \\
\text { Test } \\
\text { control }\end{array}$} & Bluegramma (Lovington) & 24 & \multirow[t]{5}{*}{ None } & & \multirow{5}{*}{$\begin{array}{l}\text { Our suggested } \\
\text { all-native } \\
\text { control }\end{array}$} \\
\hline & $\begin{array}{l}\text { Western wheatgrass } \\
\text { (SERDP TC2) }\end{array}$ & 24 & & & \\
\hline & Thickspike wheatgrasses (Critana) & 24 & & & \\
\hline & Slender wheatgrass (SERDP) & 24 & & & \\
\hline & Buffalograss (Texoka) & 4 & & & \\
\hline $\begin{array}{l}5 . \\
\text { Test mix }\end{array}$ & Same natives as \#4 & $\begin{array}{l}\text { \#4 adjusted } \\
\text { proportion- } \\
\text { ally to } 21.6 \\
\text { and } 3.6 \%\end{array}$ & $\begin{array}{l}\text { Intermediate } \\
\text { wheatgrass (Al) }\end{array}$ & 10 & $\begin{array}{l}\text { Our suggested } \\
\text { all-native mix } \\
\text { plus single } \\
\text { introduced } \\
\text { species }\end{array}$ \\
\hline $\begin{array}{l}6 . \\
\text { Test mix }\end{array}$ & Same natives as \#4 & same as \#5 & $\begin{array}{l}\text { Siberian } \\
\text { wheatgrass } \\
\text { (SERDP) }\end{array}$ & 10 & $\begin{array}{l}\text { Test different } \\
\text { introduced }\end{array}$ \\
\hline $\begin{array}{l}7 . \\
\text { Test mix }\end{array}$ & Same natives as \#4 & same as \#5 & $\begin{array}{l}\text { Russian wildrye } \\
\text { (SERDP Syn-A) }\end{array}$ & 10 & $\begin{array}{l}\text { Test different } \\
\text { introduced }\end{array}$ \\
\hline
\end{tabular}

* \% seeds/plot $=$ Percent pure live seeds (PLS) per plot, which is based on numbers of seeds, not seed weight; in spring 2004, 3600 seeds were planted in each 18-m² (100-ft²) plot.

At Fort Drum we further evaluated the ecological-bridge concept with species adapted to the northeastern United States; we didn't test any of our modified cultivars. The Airport and Area 8 sites were sown in May 2002 to evaluate different seeding mixtures of the three ecological-bridge seed components. The research design was a two-way factorial; at least four to five samples were taken in each plot at each sampling time. No liquid cow manure was applied. Seeds were sown with a no-till seeder. The mixtures sown at each site are shown in Table 7. We varied the mixtures a bit from our earlier Fort Drum studies (see Section 2.2). While switchgrass is often desirable as a native, it grows tall and can carry fire, so we also tested native hairgrasses along with the shorter-growing introduced fescues. We were still using the annual weeping lovegrass as the nurse crop when these sites were seeded, although we have since dropped it as it could be considered invasive in some locations because it does not 
completely die out over the winter months. The fine fescues were a blend of Azay sheep fescue and Scaldis and Osprey hard fescue, and the hairgrasses were a blend of Norcoast bearing hairgrass, Nortran tufted hairgrass, and a common variety of tufted hairgrass. The perennial grasses were sown in a mixture; the annual weeping lovegrass was sown separately; all seeds were sown at a depth of $1.5 \mathrm{~cm}$.

Table 7. Mixtures seeded at two Fort Drum sites (22 May 2002).

\begin{tabular}{|clc|}
\hline Mixture & Species & Seeding rate (lb per Acre) \\
\hline 1 & weeping lovegrass (WL) & 2 \\
2 & weeping lovegrass & 2 \\
& hairgrass (HG) & 38 \\
3 & weeping lovegrass & 2 \\
& switchgrass (SG) & 38 \\
4 & weeping lovegrass & 2 \\
& hairgrass & 38 \\
& switchgrass & 24 \\
5 & weeping lovegrass & 2 \\
& hairgrass & 13 \\
& switchgrass & 12 \\
& fine fescues (FF) & 12 \\
6 & weeping lovegrass & 2 \\
& hairgrass & 13 \\
& fine fescues & 24 \\
7 & weeping lovegrass, & 2 \\
& switchgrass & 18 \\
& fine fescues & 18 \\
8 & weeping lovegrass & 2 \\
& fine fescues & 38 \\
& &
\end{tabular}

Figure 7 and Figure 8 show the plot layout for the two Fort Drum sites; there was one replication or main plot at each site and no spaces between plots. The plots were sampled four times at random locations, and those samplings were used as replications to analyze the data. Plot sizes at the Airport site were oriented north to south and were $55 \times 7.6 \mathrm{~m}(180 \times 25 \mathrm{ft})$. At Area 8, plots were oriented northeast to southwest; each plot was 15.25 $\mathrm{m}(50 \mathrm{ft}$ ) wide; the plots varied in length from $30.5 \mathrm{~m}$ (100 ft) to $91.4 \mathrm{~m}$ (300 ft) to 121.9 ( $400 \mathrm{ft})$. 


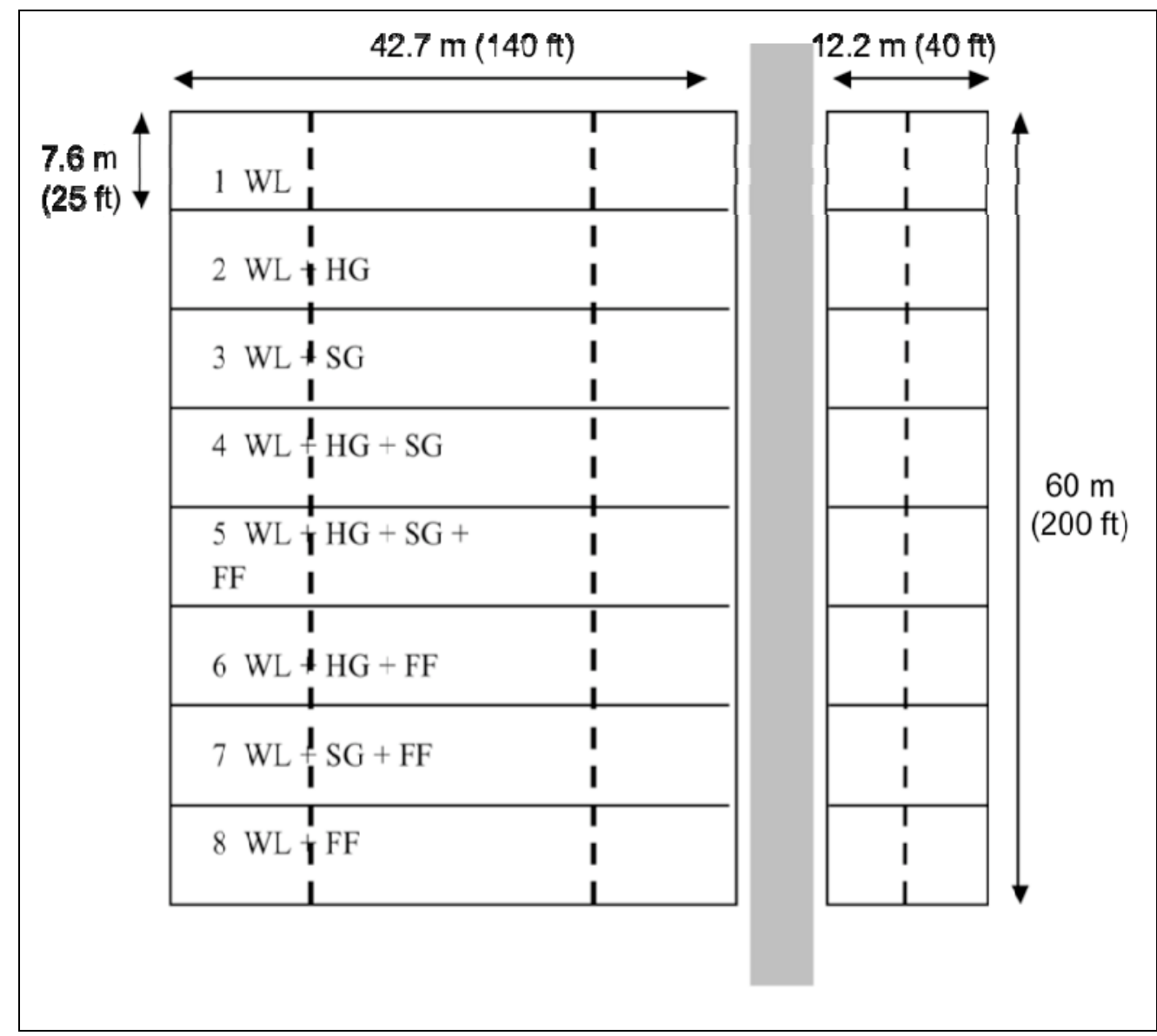

Figure 7. Arrangement of plots at the Fort Drum Airport site. $\mathrm{WL}=$ weeping lovegrass, $H G=$ hairgrass, $S G=$ switchgrass, $F F=$ fine fescues (sheep and hard fescue). 


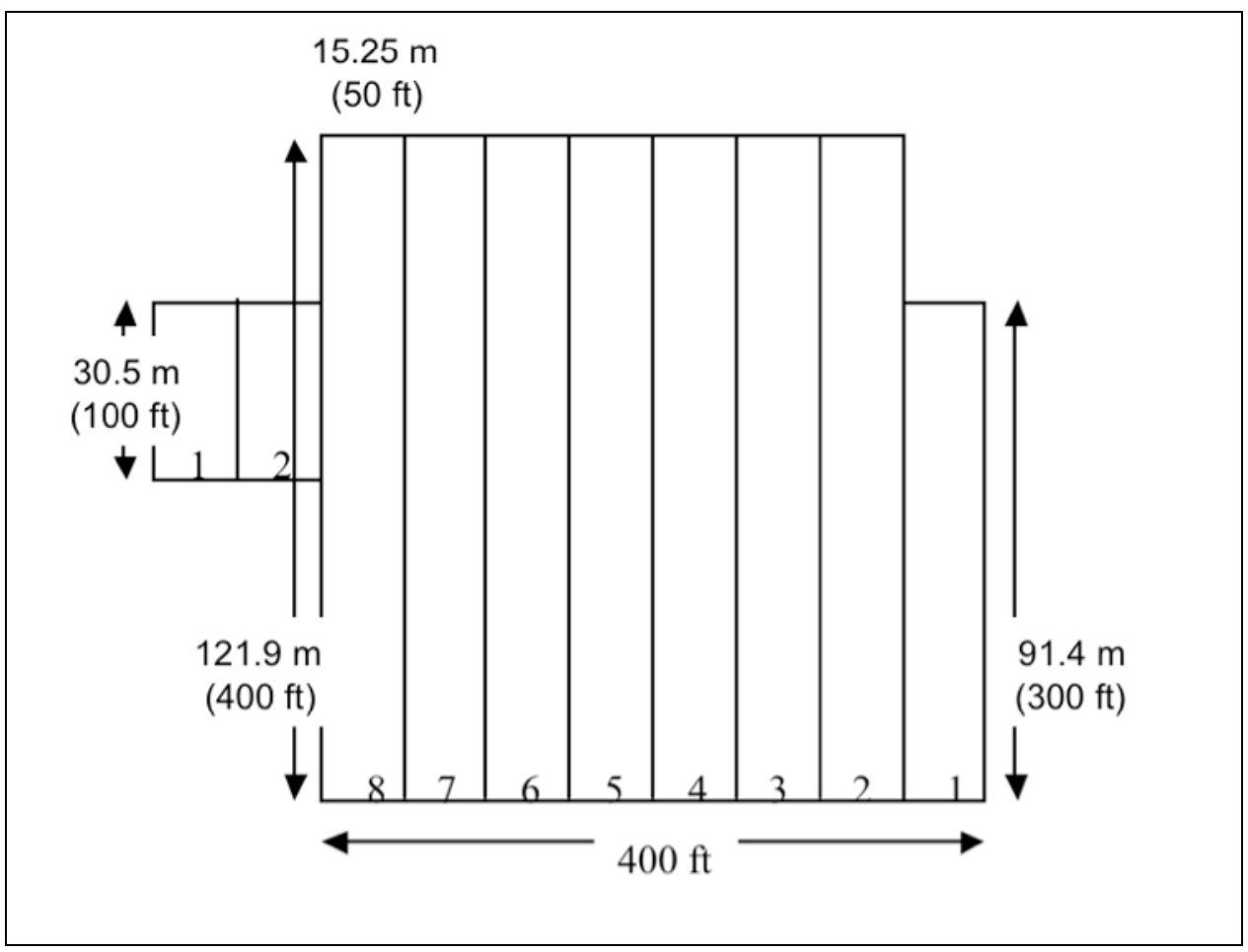

Figure 8. Arrangement of plots at the Fort Drum Area 8 site; the numbers represent the same mixtures as for the Airport site (Figure 7 and Table 7).

\subsubsection{Military traffic on monocultures at Yakima Training Center - design}

The objective of this evaluation was to compare the resiliency to military traffic of the SERDP-select germplasms that we developed with named cultivars currently on the market. Demonstration plots that were planted at YTC in October 2002 were subjected to military traffic in June 2005. A planned June 2006 tracking could not be carried out because a Stryker vehicle was not available. We monitored the plots for two seasons, completing the demonstrations by the fall of 2007.

As described above, the YTC Exit 11 plots were planted in October 2002 using a randomized complete block design with four replications and 20 species per replication. The cultivars of the species tested were the commercial variety as compared to the SERDP-select germplasm. The species tested (with named cultivars in parentheses) were: bluebunch wheatgrass (Goldar), Russian wildrye (Bozoisky-Select), Sandberg bluegrass (common), Siberian wheatgrass (Vavilov), slender wheatgrass (Pryor), Snake River wheatgrass (Secar), western wheatgrass (Rosana), Basin wildrye (Trailhead), and western yarrow (common). The tracking operations are described below in Section 5.4 . 


\subsubsection{Cultivar validation: germination and nursery-field studies - design}

Additional data needed to validate releases of the new germplasms were acquired through germination studies at CRREL and additional nurseryfield trials. Appendix C summarizes the various types of pre-variety and cultivar releases and the requirements to meet each level of release.

Germination studies were conducted in April 2005. The SERDP-select germplasms were evaluated against their known counterparts in the CRREL environmental chambers located in the greenhouse. Ten seeds of each of the various plants were placed in growth pouches in growth chambers to study plant root initiation differences. There were five replications of each germplasm per run, with each temperature run four times for a total of 200 seeds studied. The environmental chambers were set at temperatures of $10,15,20,25$, and $30^{\circ} \mathrm{C}$ with 12 hours of daylight. Plant root initiation for the seed was determined according to the Association of Official Seed Certifying Agencies (AOSCA) publication (2003). Pouches were examined daily for up to 28 days.

Space-planted nursery-field trials to validate our cultivars as compared to other range grass cultivars were conducted at several USDA sites to provide data for Exhibits B, C, and D for Plant Variety Protection (PVP) as described in Appendix C. Six nursery-field trials for Bozoisky II Russian wildrye were planted in 1999 during our SERDP project as part of the Northern Plains Area Regional Trials (NPA). Between 2002 and 2005, five fall-dormant-seeded nurseries were established to compare seedling establishment and stand development of our other cultivars (Recovery western wheatgrass, FirstStrike slender wheatgrass, Vavilov II Siberian wheatgrass) and other range grass cultivars. Data from the YTC Exit 11 (fall-dormant-seeded), the two Camp Guernsey sites (spring-seeded), and Dugway (fall-dormant-seeded) were also included in cultivar validation. Plots in each trial were arranged in a randomized complete block with four replications. Entries were seeded at a rate of one pure live seed $\mathrm{cm}^{-1}$ at a seeding depth of $0.63 \mathrm{~cm}$ in five rows. Plots size was $1.5 \times 8 \mathrm{~m}$. Table 8 lists the nursery-field sites and ecoregions they represent. 3

\footnotetext{
3 Level III and Level IV Ecoregions of the Continental United States, National Health and Environmental Effects Research Laboratory, U.S. EPA
} 
Table 8. Locations of space-planted nursery-field trials for cultivar validation

\begin{tabular}{|c|c|c|c|c|}
\hline Site & Location & $\begin{array}{l}\text { Annual } \\
\text { precip. }\end{array}$ & Ecoregions & $\begin{array}{l}\text { Cultivar validation data } \\
\text { for }\end{array}$ \\
\hline Beaver, UT & $\begin{array}{l}38^{\circ} 20^{\prime} \mathrm{N} \\
112^{\circ} 35^{\prime} \mathrm{W} \\
\text { elevation } \\
1979 \mathrm{~m}\end{array}$ & $\begin{array}{l}34.3 \\
\mathrm{~cm}\end{array}$ & $\begin{array}{l}\text { Level III Central Basin and } \\
\text { Range, Level IV Woodland- } \\
\text { and Shrub-covered Low } \\
\text { Mountains }\end{array}$ & Recovery western wg \\
\hline Malta, ID & $\begin{array}{l}42^{\circ} 18^{\prime} \mathrm{N} \\
113^{\circ} 11^{\prime} \mathrm{W} \\
\text { elevation } \\
1480 \mathrm{~m}\end{array}$ & $\begin{array}{l}27.9 \\
\mathrm{~cm}\end{array}$ & $\begin{array}{l}\text { Level III Northern Basin and } \\
\text { Range, Level IV Saltbush } \\
\text { Dominated Valleys }\end{array}$ & $\begin{array}{l}\text { Recovery western wg } \\
\text { FirstStrike slender wg } \\
\text { Vavilov II Siberian wg }\end{array}$ \\
\hline $\begin{array}{l}\text { Fillmore, UT } \\
\text { site } 1 \text { (lower } \\
\text { site) }\end{array}$ & $\begin{array}{l}39^{\circ} 12^{\prime} \mathrm{N} \\
112^{\circ} 14^{\prime} \mathrm{W} \\
\text { elevation } \\
1776 \mathrm{~m}\end{array}$ & $\begin{array}{l}37.6 \\
\mathrm{~cm}\end{array}$ & $\begin{array}{l}\text { Level III Central Basin and } \\
\text { Range, Level IV Sagebrush } \\
\text { Basins and Slopes }\end{array}$ & $\begin{array}{l}\text { Recovery western wg } \\
\text { FirstStrike slender wg }\end{array}$ \\
\hline $\begin{array}{l}\text { Fillmore, UT } \\
\text { site } 2 \text { (upper } \\
\text { site) }\end{array}$ & $\begin{array}{l}39^{\circ} 13^{\prime} \mathrm{N} \\
112^{\circ} 12^{\prime} \mathrm{W} \\
\text { elevation } \\
1843 \mathrm{~m}\end{array}$ & $\begin{array}{l}39.5 \\
\mathrm{~cm}\end{array}$ & $\begin{array}{l}\text { Level III Central Basin and } \\
\text { Range, Level IV Woodland- } \\
\text { and Shrub-covered Low } \\
\text { Mountains }\end{array}$ & $\begin{array}{l}\text { Recovery western wg } \\
\text { FirstStrike slender wg } \\
\text { Vavilov II Siberian wg }\end{array}$ \\
\hline $\begin{array}{l}\text { Curlew Valley, } \\
\text { ID }\end{array}$ & $\begin{array}{l}42^{\circ} 02^{\prime} \mathrm{N} \\
112^{\circ} 40^{\prime} \mathrm{W} \\
\text { elevation } \\
1405 \mathrm{~m}\end{array}$ & $\begin{array}{l}30.7 \\
\mathrm{~cm}\end{array}$ & $\begin{array}{l}\text { Level III Central Basin and } \\
\text { Range, Level IV Shadscale- } \\
\text { dominated Saline Basins }\end{array}$ & $\begin{array}{l}\text { Recovery western wg } \\
\text { Vavilov II Siberian wg } \\
\text { Bozoisky II Russian wr }\end{array}$ \\
\hline $\begin{array}{l}\text { Exit 11, } \\
\text { Yakima, WA }\end{array}$ & $\begin{array}{l}46^{\circ} 50^{\prime} \mathrm{N} \\
120^{\circ} 22^{\prime} \mathrm{W} \\
\text { elevation } \\
700 \mathrm{~m}\end{array}$ & $\begin{array}{l}22.6 \\
\mathrm{~cm}\end{array}$ & $\begin{array}{l}\text { Level III Columbia Plateau, } \\
\text { Level IV Yakima Folds }\end{array}$ & $\begin{array}{l}\text { Recovery western wg } \\
\text { FirstStrike slender wg } \\
\text { Vavilov II Siberian wg } \\
\text { Bozoisky II Russian wr }\end{array}$ \\
\hline $\begin{array}{l}\text { River site, } \\
\text { Camp } \\
\text { Guernsey, WY }\end{array}$ & $\begin{array}{l}42^{\circ} 15^{\prime} \mathrm{N} \\
104^{\circ} 44^{\prime} \mathrm{W} \\
\text { elevation } \\
1320 \mathrm{~m}\end{array}$ & $\begin{array}{l}31.7 \\
\mathrm{~cm}\end{array}$ & $\begin{array}{l}\text { Level III High Plains, } \\
\text { Level IV Moderate Relief } \\
\text { Rangeland }\end{array}$ & $\begin{array}{l}\text { Recovery western wg } \\
\text { FirstStrike slender wg } \\
\text { Vavilov II Siberian wg } \\
\text { Bozoisky II Russian wr }\end{array}$ \\
\hline $\begin{array}{l}\text { Tower site, } \\
\text { Camp } \\
\text { Guernsey, WY }\end{array}$ & $\begin{array}{l}42^{\circ} 14^{\prime} \mathrm{N} \\
104^{\circ} 44^{\prime} \mathrm{W} \\
\text { elevation } \\
1393 \mathrm{~m}\end{array}$ & $\begin{array}{l}31.7 \\
\mathrm{~cm}\end{array}$ & $\begin{array}{l}\text { Level III High Plains, } \\
\text { Level IV Moderate Relief } \\
\text { Rangeland }\end{array}$ & $\begin{array}{l}\text { Recovery western wg } \\
\text { FirstStrike slender wg } \\
\text { Vavilov II Siberian wg }\end{array}$ \\
\hline Dugway, UT & & $\begin{array}{l}19.5 \\
\mathrm{~cm}\end{array}$ & $\begin{array}{l}\text { Level III Central Basin and } \\
\text { Range, Level IV Woodland- } \\
\text { and Shrub-covered Low } \\
\text { Mountains }\end{array}$ & Vavilov II Siberian wg \\
\hline Bluecreek, UT & $\begin{array}{l}41^{\circ} 56^{\prime} \mathrm{N} \\
112^{\circ} 26^{\prime} \mathrm{W} \\
\text { elevation } \\
1653 \mathrm{~m}\end{array}$ & $\begin{array}{l}35.0 \\
\mathrm{~cm}\end{array}$ & $\begin{array}{l}\text { Level III Central Basin and } \\
\text { Range, } \\
\text { Level IV Sagebrush Basins } \\
\text { and Slopes }\end{array}$ & Bozoisky-II Russian wr \\
\hline
\end{tabular}




\begin{tabular}{|c|c|c|c|c|}
\hline Site & Location & $\begin{array}{l}\text { Annual } \\
\text { precip. }\end{array}$ & Ecoregions & $\begin{array}{l}\text { Cultivar validation data } \\
\text { for }\end{array}$ \\
\hline $\begin{array}{l}\text { Green } \\
\text { Canyon, UT }\end{array}$ & $\begin{array}{l}41^{\circ} 46^{\prime} \mathrm{N} \\
111^{\circ} 47^{\prime} \mathrm{W} \\
\text { elevation } \\
1520 \mathrm{~m}\end{array}$ & $\begin{array}{l}44.9 \\
\mathrm{~cm}\end{array}$ & $\begin{array}{l}\text { Level III Central Basin and } \\
\text { Range, } \\
\text { Level IV Malad and Cache } \\
\text { Valleys }\end{array}$ & Bozoisky-II Russian wr \\
\hline Mead, NE & $\begin{array}{l}41^{\circ} 13^{\prime} \mathrm{N}, \\
96^{\circ} \\
29^{\prime} \mathrm{W}\end{array}$ & $\begin{array}{l}70.6 \\
\mathrm{~cm}\end{array}$ & $\begin{array}{l}\text { Level III Western Corn Belt } \\
\text { Plains, Level IV } \\
\text { Nebraska/Kansas Loess } \\
\text { Hills }\end{array}$ & Bozoisky-II Russian wr \\
\hline Sidney, NE & $\begin{array}{l}41^{\circ} 23^{\prime} \mathrm{N} \\
103^{\circ} \mathrm{O}^{\prime} \mathrm{W}\end{array}$ & $\begin{array}{l}42.2 \\
\mathrm{~cm}\end{array}$ & $\begin{array}{l}\text { Level III High Plains, Level IV } \\
\text { Flat to Rolling Cropland }\end{array}$ & Bozoisky-II Russian wr \\
\hline Mandan, ND & $\begin{array}{l}46^{\circ} 48^{\prime} \mathrm{N}, \\
100^{\circ} 46^{\prime} \mathrm{W}, \\
\text { elevation } \\
510 \mathrm{~m}\end{array}$ & $\begin{array}{l}41.4 \\
\mathrm{~cm}\end{array}$ & $\begin{array}{l}\text { Level III Northwestern } \\
\text { Glaciated Plains, Level IV } \\
\text { Collapsed Glacial Outwash }\end{array}$ & Bozoisky-II Russian wr \\
\hline Miles City, MT & $\begin{array}{l}46^{\circ} 22^{\prime} \mathrm{N} \\
105^{\circ} 5^{\prime} \mathrm{W} \\
\text { elevation } \\
721 \mathrm{~m}\end{array}$ & $\begin{array}{l}33.0 \\
\mathrm{~cm}\end{array}$ & $\begin{array}{l}\text { Level III Northwestern Great } \\
\text { Plains, Level IV River Breaks }\end{array}$ & Bozoisky-II Russian wr \\
\hline
\end{tabular}

$w g=$ wheatgrass; $w r=$ wildrye

\subsection{Field testing}

Field testing consisted of measurements of plant stands for several years after the various monoculture germplasm and seeding mixtures were sown. After the Stryker tracking event at YTC in 2005, plots were measured for two additional years. Table 9 summarizes the activities and data taken at the various field sites. Descriptions of the activities are given in the sections below; measurement protocol is described in Section 5.5.

Table 9. Time line of field events.

\begin{tabular}{|c|l|l|l|l|l|l|}
\hline & $\begin{array}{l}\text { YTC - } \\
\text { Exit 11 }\end{array}$ & $\begin{array}{l}\text { Fort Guernsey } \\
\text { - River site }\end{array}$ & $\begin{array}{l}\text { Fort Guernsey } \\
\text {-Tower site }\end{array}$ & $\begin{array}{l}\text { Dugway Proving } \\
\text { Grounds }\end{array}$ & $\begin{array}{l}\text { Fort Drum - } \\
\text { Airport site }\end{array}$ & $\begin{array}{l}\text { Fort Drum - } \\
\text { Area 8 site }\end{array}$ \\
\hline $\begin{array}{c}2002- \\
\text { Spring }\end{array}$ & rototilled & & & $\begin{array}{l}\text { Mixes seeded } \\
\text { (22 May) }\end{array}$ & $\begin{array}{l}\text { Mixes seeded } \\
\text { (22 May) }\end{array}$ \\
\hline Summer & $\begin{array}{l}\text { Roundup }{ }^{\circledR} \text { \& } \\
\text { Trimec } \\
\text { spraying) }\end{array}$ & & & & & \\
\hline Fall & $\begin{array}{l}\text { Monocultures } \\
\text { \& mixes } \\
\text { seeded (Oct } \\
\text { 21-22) }\end{array}$ & & & & & \\
\hline
\end{tabular}




\begin{tabular}{|c|c|c|c|c|c|c|}
\hline & $\begin{array}{l}\text { YTC - } \\
\text { Exit } 11\end{array}$ & $\begin{array}{l}\text { Fort Guernsey } \\
\text { - River site }\end{array}$ & $\begin{array}{l}\text { Fort Guernsey } \\
\text {-Tower site }\end{array}$ & $\begin{array}{l}\text { Dugway Proving } \\
\text { Grounds }\end{array}$ & $\begin{array}{l}\text { Fort Drum - } \\
\text { Airport site }\end{array}$ & $\begin{array}{l}\text { Fort Drum - } \\
\text { Area } 8 \text { site }\end{array}$ \\
\hline $\begin{array}{l}2003- \\
\text { Spring }\end{array}$ & $\begin{array}{l}\text { Establishment } \\
\text { measurements } \\
\text { (14 May) }\end{array}$ & Rototilled & & & & \\
\hline Summer & & $\begin{array}{l}\text { Roundup }{ }^{\circledR} \& \\
\text { Trimec }^{\circledR}(\text { three } \\
\text { sprayings) }^{\text {a }}\end{array}$ & & & $\begin{array}{l}\text { 1-year } \\
\text { measurements } \\
\text { ( } 24 \text { June) }\end{array}$ & $\begin{array}{l}\text { 1-year } \\
\text { measurements } \\
\text { (24 June) }\end{array}$ \\
\hline $\begin{array}{l}2004- \\
\text { Spring }\end{array}$ & $\begin{array}{l}\text { 1-year } \\
\text { measurements } \\
\text { (19 April) }\end{array}$ & $\begin{array}{l}\text { Monocultures } \\
\& \text { mixes } \\
\text { seeded } \\
\text { (31 March) } \\
\text { Establishment } \\
\text { measurements } \\
\text { (2 June) }\end{array}$ & Rototilling & & & \\
\hline Summer & & & $\begin{array}{l}\text { Roundup }{ }^{\circledR} \& \\
\text { Trimec }^{\circledR} \text { (three } \\
\text { sprayings) }^{\text {a }}\end{array}$ & & $\begin{array}{l}\text { 2-year } \\
\text { measurements } \\
\text { (29 June) }\end{array}$ & $\begin{array}{l}\text { No } \\
\text { measurements } \\
\text { (site was used } \\
\text { for training) }\end{array}$ \\
\hline $\begin{array}{l}2005- \\
\text { Spring }\end{array}$ & $\begin{array}{l}\text { 2-year } \\
\text { measurements } \\
\text { ( } 2 \text { June) } \\
\text { Stryker tracking } \\
\text { (14 June) }\end{array}$ & \begin{tabular}{|l} 
1-year \\
measurements \\
( 2 June)
\end{tabular} & $\begin{array}{l}\text { Monocultures } \\
\& \text { mixes } \\
\text { seeded } \\
\text { (23 March) } \\
\text { Establishment } \\
\text { measurements } \\
\text { (2June) }\end{array}$ & & & \\
\hline Summer & & & & Rototilled & $\begin{array}{l}\text { 3-year } \\
\text { measurements } \\
\text { (7 Sept) }\end{array}$ & \\
\hline Fall & & & & $\begin{array}{l}\text { Monocultures } \\
\text { seeded ( } 7 \mathrm{Nov})\end{array}$ & & \\
\hline $\begin{array}{l}2006- \\
\text { Spring }\end{array}$ & $\begin{array}{l}\text { Stand } \\
\text { frequency } 1 \\
\text { year after } \\
\text { tracking }\end{array}$ & & & $\begin{array}{l}\text { Establishment } \\
\text { measurements } \\
(10 \text { May) }\end{array}$ & $\begin{array}{l}\text { 4-year } \\
\text { measurements } \\
\text { ( } 7 \text { June) }\end{array}$ & \\
\hline Summer & & $\begin{array}{l}\text { 2-year } \\
\text { measurements } \\
\text { (19 July) }\end{array}$ & $\begin{array}{l}\text { 1-year } \\
\text { measurements } \\
\text { (19 July) }\end{array}$ & & & \\
\hline $\begin{array}{l}2007 \text { - } \\
\text { Spring }\end{array}$ & $\begin{array}{l}\text { Stand } \\
\text { frequency } 2 \\
\text { years after } \\
\text { tracking }\end{array}$ & & $\begin{array}{l}\text { No } \\
\text { measurements } \\
\text { due to drought } \\
\text { conditions }\end{array}$ & $\begin{array}{l}\text { No } \\
\text { measurements }\end{array}$ & & \\
\hline
\end{tabular}




\subsubsection{Field evaluations of new germplasms: comparisons of germplasms with existing cultivars (monocultures) - testing}

Evaluations of monocultures at YTC and Guernsey consisted of measurements taken annually (spring) over a 2-year period, except at the Tower site at Guernsey where we were unable to take 2-year measurements due to drought. At Dugway, we took establishment measurements, but no further data as the establishment was very poor. The data collected included establishment and persistence of sown species. Establishment and persistence were recorded as percent cover, measured either by using modified Vogel frames of different sizes or by visual ratings (both protocols are described in Section 5.5 below). We also recorded percent bare ground, percent dead plants, and percent weeds in many instances.

\subsubsection{Ecological-bridge demonstration (mixtures) - testing}

The establishment of plants during the first growing season, 2-6 months after seeding, was measured at YTC and Camp Guernsey by taking frequency measurements of total plants. At both sites, we used a 48-grid frame of $6.35 \times 6.35$-cm (2.5 x 2.5-in.) squares (see Section 5.5.1 on the modified Vogel frame) for the establishment measurements. It was not possible to distinguish among the different species during the early stage of growth when planting seed mixtures. Following the establishment year, we took spring or summer measurements for the next 2 years with a 24grid frame of $12.7 \times 12.7-\mathrm{cm}$ ( $5 \times 5$-in.) squares at YTC and at Camp Guernsey in 2005. In 2006 at Camp Guernsey, we took visual ratings for the 2-year River site measurements and 1-year Tower site measurements; we were unable to take 2-year measurements at the Tower site due to drought conditions.

At Fort Drum, we took measurements for 4 years at the Airport site; Area 8 was used for training after the first year, so we have only 1-year measurements for that site. We measured plant cover of sown species, bare ground, and weedy species at all three facilities. The first-year measurements were taken with a 24-grid frame of $12.7 \times 12.7-\mathrm{cm}(5 \times 5$-in.) squares; in the remaining years, we used a 36 -grid frame of $12.7 \times 12.7-\mathrm{cm}$ (5 x 5-in.) squares (see Section 5.5.1 on the modified Vogel frame); at least five samples were taken per plot. 


\subsubsection{Military traffic on monocultures at YTC - testing}

On 2 June 2005, we made a reconnaissance of the site to determine the condition of the species and to see if it was a good time to do the traffic experiment. The vegetation was very uneven, and several species were nearly gone. Precipitation on the plots had been sparse for some time, and the soil was very dry. Only a few plots with Vavilov and SERDP-modified Vavilov Siberian wheatgrass, SERDP western wheatgrass, and Bozoisky (Syn A) Russian wildrye were reasonably covered.

A Stryker was used to track the plot on 14 June 2005. The vehicle has a 2.25-m (7.4-ft) track width and 38-cm (15-in.) tire width when loaded. Rates of tracking and the vehicle velocity required to achieve both light and heavy treatments were determined in the field outside of the plot area. These off-site tests showed that straight tracks of one and four passes per replication at a vehicle speed of $20 \mathrm{mph}$ produced sufficiently different rutting.

Traffic patterns were set up such that three rates of disturbance-zero pass, one pass, and four passes - would be applied per replication - a total of 12 treatments. Disturbance rates were randomly applied to each replication and perpendicular to planted entries (Figure 9).

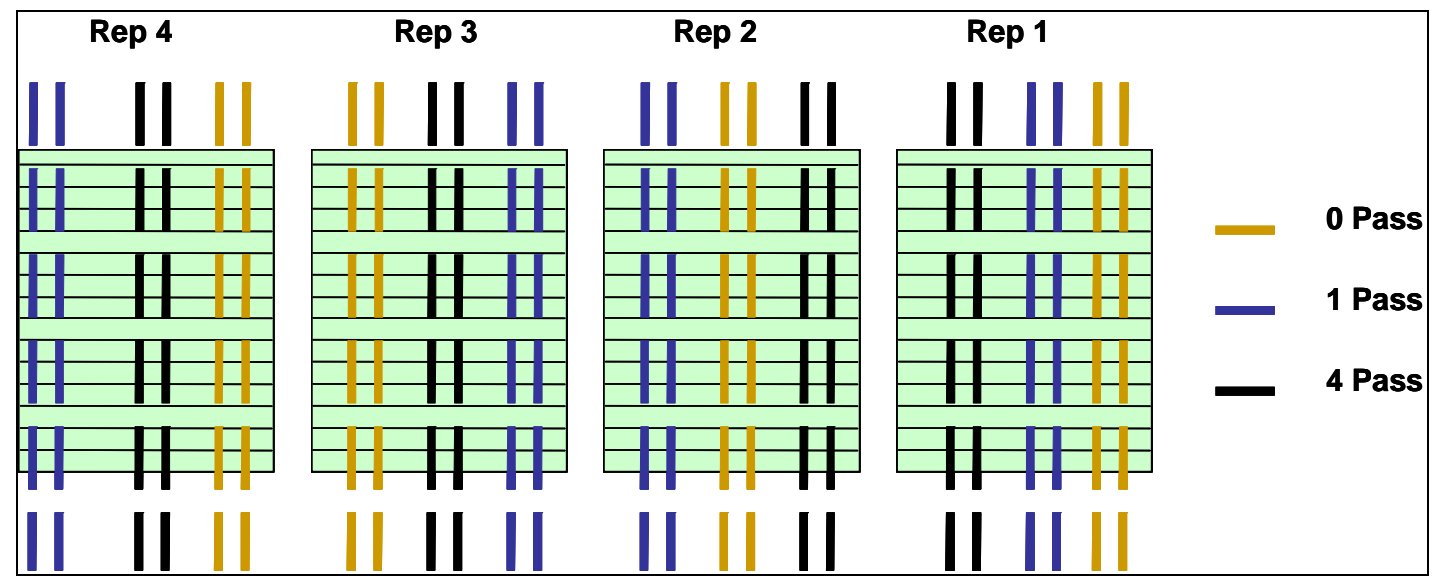

Figure 9. Traffic design at YTC Exit 11 (Note: Plot 1, Rep 1 is in the lower right corner; plot numbers go from the bottom up).

Measurements taken before and after the traffic passes and both 1 and 2 years after the event are summarized in Table 10. The locations of the measurements in relation to the ruts are shown in Figure 10. The measurement protocols are described in Section 5.5. 
Table 10. Soil and vegetation measurements before and after traffic event (June 2005), YTC Exit 11.

\begin{tabular}{|l|l|c|l|c|c|}
\hline Characteristic & Protocol & Before & $\begin{array}{l}\text { Immed. } \\
\text { after }\end{array}$ & $\begin{array}{l}\text { After } \\
1 \mathrm{yr}\end{array}$ & $\begin{array}{l}\text { After } \\
2 \mathrm{yr}\end{array}$ \\
\hline Soil characterization \\
\hline Shear strength & Pilcon shear vane & $\mathrm{X}$ & & $\mathrm{X}$ & $\mathrm{X}$ \\
\hline Soil moisture & Delta T ML2x moisture probe & $\mathrm{X}$ & & $\mathrm{X}$ & $\mathrm{X}$ \\
\hline Soil bulk density & Drive-cylinder, 283-cc soil cores & $\mathrm{X}$ & & & \\
\hline Soil compaction & Drop-cone penetrometer & & $\mathrm{X}$ & $\mathrm{X}$ & $\mathrm{X}$ \\
\hline Rut depth & & $\mathrm{X}$ & $\mathrm{X}$ & $\mathrm{X}$ \\
\hline Vegetation response & Pin profilometer & $\mathrm{X}$ & $\mathrm{X}$ & $\mathrm{X}$ & $\mathrm{X}$ \\
\hline \multicolumn{2}{|l|}{ Plant resiliency } & Percent cover & & & \\
\hline
\end{tabular}

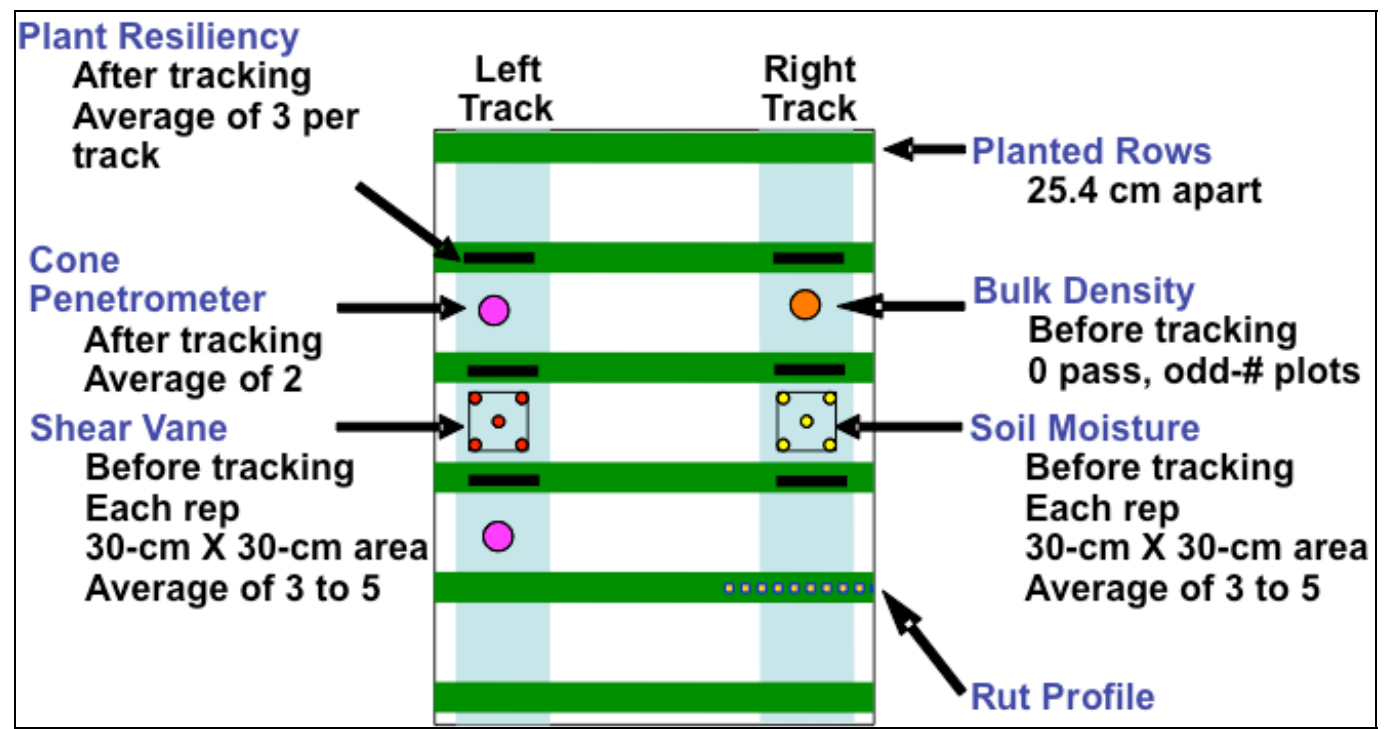

Figure 10. Location of sampling points before and after tracking; green represents planted rows, which are perpendicular to the tracking ruts.

The soil-characterization measurements were made to fully define the soil conditions prior to tracking so that the degrees of vehicle impacts from future tracking experiments could be compared to the soil conditions and correlations defined.

In 2006 and 2007 ( 1 and 2 years after tracking) soil physical properties (shear strength, soil moisture and compaction) were remeasured, with the exception of soil bulk density. Rut profiles were also remeasured to determine changes in the profile over time. 
To measure rebound of the planted species, the three center rows of each track were measured using the $12.5 \times 12.5 \mathrm{~cm}$ ( $5 \times 5$-in.) grid to determine the percent cover. The two tracks were then averaged to determine percent cover for each species.

\subsubsection{Cultivar validation: Germination and nursery-field studies - testing}

In the germination studies in the CRREL environment chambers, plant root initiation for the seed was determined according to the AOSCA (2003). Each growth pouch was examined daily for up to 28 days.

In the space-planted field trials for cultivar evaluation, seedling establishment and subsequent stand persistence were measured as plant frequency using a modified Vogel frame (see Section 5.5.1). Seedling frequency was determined with a 48 -square grid of $5.1 \times 5.1-\mathrm{cm}$ quadrants laid over the drilled rows. This was repeated three times along the 8-m row, for a total of 144 quadrants. The same procedure was used to determine subsequent stand frequency except that the quadrants were $10.2 \times 10.2-\mathrm{cm}$, for a total of 72 quadrants per plot.

All data were subjected to analysis using the MIXED procedure of SAS and replications were considered random, and the SOLUTION option was used to allow estimation of LS-means (SAS Institute Inc., 1999). All mean separations were made on the basis of least significant differences at the 0.05 probability level. Forage yields or dry weights were also measured (see Section 5.5.3).

\subsection{Sampling protocol}

This section describes each measuring technique used in the various parts of our demonstrations. Sampling dates are given in the timeline in Table 9 above; soil data protocols used before and after tracking are summarized in Table 10 above. Table 11 below summarizes the type of vegetation sampling and number of samples at each demonstration site. 
Table 11. Summary of vegetation sampling protocol at each site.

\begin{tabular}{|c|c|c|c|c|c|}
\hline Site & Establishment & 1 year & 2 years & 3 years & 4 years \\
\hline YTC & $\begin{array}{l}\text { 48-grid frame } \\
4 \text { reps; } \\
4 \text { samples/rep }\end{array}$ & $\begin{array}{l}\text { 24-grid frame } \\
4 \text { reps; } \\
3 \text { samples/rep }\end{array}$ & $\begin{array}{l}\text { 24-grid frame } \\
4 \text { reps; } \\
5 \text { samples/rep }\end{array}$ & --- & --- \\
\hline $\begin{array}{l}\text { Guernsey } \\
\text { River site }\end{array}$ & $\begin{array}{l}\text { 48-grid frame; } \\
3 \text { reps; } \\
3 \text { samples/rep }\end{array}$ & $\begin{array}{l}24 \text {-grid frame } \\
3 \text { reps; } \\
3 \text { samples/rep }\end{array}$ & $\begin{array}{l}\text { Visual ratings } \\
\text { ( } 3 \text { teams of } 2 \\
\text { people) }\end{array}$ & --- & --- \\
\hline $\begin{array}{l}\text { Guernsey } \\
\text { Tower site }\end{array}$ & $\begin{array}{l}\text { 48-grid frame; } \\
3 \text { reps; } \\
3 \text { samples/rep }\end{array}$ & $\begin{array}{l}\text { Visual ratings } \\
\text { (3 teams of } 2 \\
\text { people) }\end{array}$ & -- & --- & -- \\
\hline Dugway & $\begin{array}{l}\text { 48-grid frame; } \\
4 \text { reps; } \\
3 \text { samples/rep }\end{array}$ & -- & -- & -- & --- \\
\hline $\begin{array}{l}\text { Fort Drum } \\
\text { Area } 8\end{array}$ & -- & $\begin{array}{l}\text { 24-grid frame; } \\
4 \text { samples/plot }\end{array}$ & -- & --- & -- \\
\hline $\begin{array}{l}\text { Fort Drum } \\
\text { Airport }\end{array}$ & -- & $\begin{array}{l}\text { 24-grid frame } \\
4 \text { samples/plot }\end{array}$ & $\begin{array}{l}\text { 36-grid frame; } \\
4 \text { samples/plot }\end{array}$ & $\begin{array}{l}\text { 36-grid } \\
\text { frame; } \\
4 \text { samples/ } \\
\text { plot }\end{array}$ & $\begin{array}{l}\text { 36-grid } \\
\text { frame; } \\
4 \text { samples/ } \\
\text { plot }\end{array}$ \\
\hline $\begin{array}{l}\text { YTC } \\
\text { tracking } \\
\text { plant cover }\end{array}$ & $\begin{array}{l}24 \text {-grid frame } \\
4 \text { reps; } \\
5 \text { samples/rep }\end{array}$ & $\begin{array}{l}\text { 24-grid frame } \\
4 \text { reps; } \\
3 \text { samples/rep }\end{array}$ & $\begin{array}{l}\text { 24-grid frame } \\
4 \text { reps; } \\
3 \text { samples/rep }\end{array}$ & & \\
\hline
\end{tabular}

\subsubsection{Vogel frequency frame (modified)}

For most of our establishment and persistent measurements, we used a modified Vogel frame with an internal grid (Vogel and Masters 2001). Different sized grids were used. The grids consist of a metal frame containing 24, 36, or 48 squares created by heavy duty wire; the squares are aligned in a six-by-four, six-by-six, or six-by-eight pattern, and measured $12.7 \times 12.7 \mathrm{~cm}(5 \times 5 \mathrm{in}$.) in the 24-square frame or $6.35 \times 6.35$ $\mathrm{cm}(2.5 \times 2.5 \mathrm{in}$.) in the $36-$ and 48 -square frames. We randomly or systematically placed the grid within a seeded area. The number of cells containing plants were counted and converted into frequency of occurrence or stand percentages by dividing the number of cells that contain a seeded plant by the total number of squares counted. Similar methods were used to obtain the percentages of bare ground, dead plants, or weeds. 


\subsubsection{Visual frequency ratings}

At some sites, we recorded a visual rating of ground cover, weeds, litter, and bare ground. Three teams of two rated each plot overall, and their values were used to get the percentages of each condition.

\subsubsection{Plant biomass (forage yield)}

Plant biomass (forage yield or dry plant matter) was evaluated in the spaced-plant nurseries. At some locations, individual plots were harvested with a sickle-bar harvester to an 8-cm stubble height just prior to anthesis. Forage samples were taken from each plot and dried to a constant weight in a forced-air oven at $60{ }^{\circ} \mathrm{C}$ for 48 hours to determine dry matter percentage.

\subsubsection{Shear strength}

Soil shear strength was measured with a Pilcon shear vane (ELE model CL-612 Hand Vane Tester). Measurements were made in three to five locations in a $30.5 \times 30.5-\mathrm{cm}$ (12 x 12-in.) area from the center of the right track in each plot (Figure 10). The five values were then averaged to give the shear strength for that location. Soil shear strength at YTC Exit 11 was taken immediately before the June 2005 traffic event.

\subsubsection{Soil moisture}

Soil moistures were measured in the same three- to five-measurement pattern (Figure 10) with a Delta T type ML2x probe/HH2 moisture meter from each replication prior to tracking and averaged to give the moisture in that plot.

\subsubsection{Soil bulk density}

Bulk density measurements were taken with a $283 \mathrm{~cm}^{3}$ drive cylinder corer in the o-pass treatment, from plots $1,3,5,7,9,11,13,15,17$ and 19 of each replication prior to tracking (see Table 38 in Appendix Section D.2 for the seeding list by plots).

\subsubsection{Soil compaction (penetration resistance)}

A drop-cone penetrometer was used to measure soil compaction before tracking in the zero-pass treatment and immediately following tracking in 
the low- and high-rate plots. All compaction measurements were taken from the left-hand track (looking in the direction of vehicle movement) with two samples per species (plot) averaged to give depth of penetration for each plot.

\subsubsection{Rut depth}

Rut profiles were taken from the right-hand track with a pin profilometer as described by Affleck et al. (2004) (Figure 11). Profiles for the four-pass treatments were taken in every plot for all replications, for the 1-pass treatment from plots 4, 8, 12, 16, and 20 for each replication, and for the o-pass treatments from plots 2, 10 and 18 (see Table 38 in Appendix D.2 for the seeding list by plots).

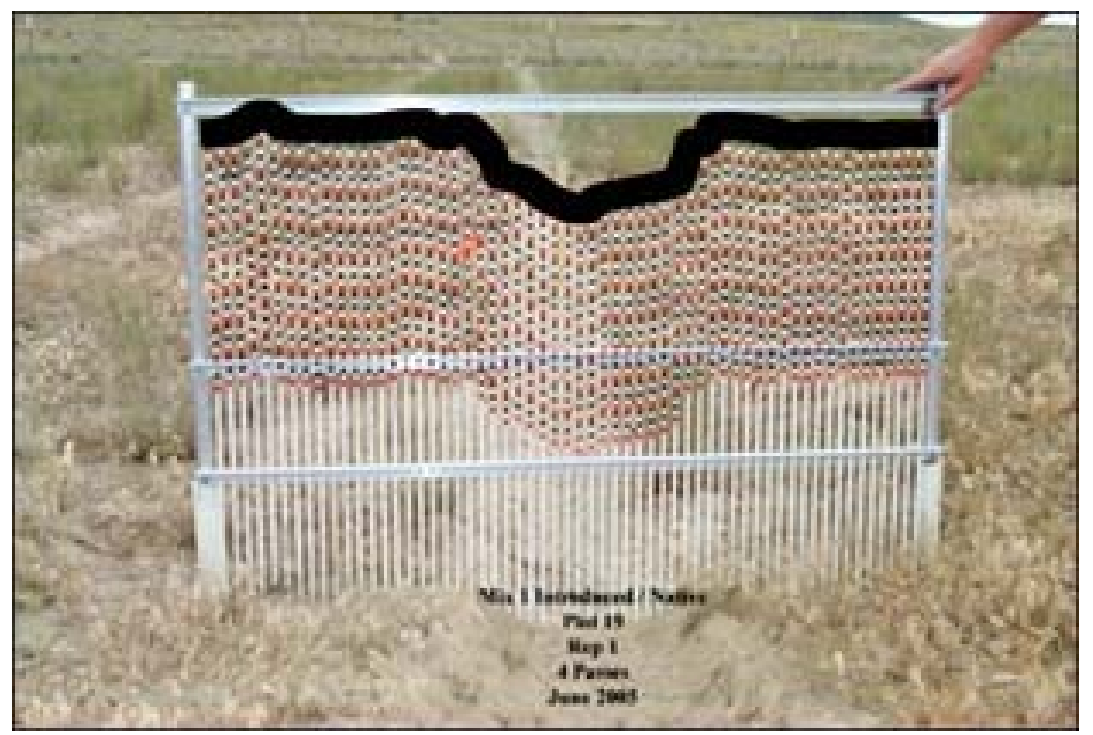

Figure 11. Pin profilometer used in a 4-pass rut immediately after tracking in June 2005.

\subsubsection{Statistical analyses}

Differences in establishment rates and persistence between the SERDPselect germplasms and standard cultivars were done with multiple means comparison tests (protected LSD). Differences in the establishment rate, growth of invasive plants, and plant regrowth after tracking of the ecobridge seeds were subjected to analysis of variance using PROC MIXED (SAS 1999), with entries as fixed and replications and years as random variable effects. Mean separations were made on the basis of the least significant difference (LSD) test at an alpha $=0.05$ probability level. 


\subsection{Sampling results}

These sections provide summary data and figures. More detailed data are presented in Appendix D.

All the demonstration plots were seeded before most of the modified germplasms had been named and released. At that time, the modified seeds were referred to as SERDP-select. For clarity in this summary section, we refer to those modified plant materials by their release names, with the exception of Snake River wheatgrass, which has not yet been released or named.

\subsubsection{Field evaluations of new germplasms: comparisons of germplasms with existing cultivars (monocultures) - results}

\subsubsection{Yakima Training Center monocultures}

Table 12, Figure 12, and Figure 13 show stand establishment and percent stand over 3 years from the Exit 11 seeding on 21-22 October 2002 (full data is given in Appendix D.5). Variety names are given in parentheses; the SERDP-modified entries are shaded in green. The SERDP-modified entries generally did better than the standard cultivars; the SERDP cultivars of Siberian wheatgrass and western wheatgrass had significantly better cover than their counterparts in all 3 years. In the last year (2005), the vegetation was very uneven, several species were nearly gone, and the plots were infested with bill bugs. Precipitation on the plots had been sparse for some time, and the soil was very dry. Only a few plots with Vavilov and SERDP-modified Vavilov-II Siberian wheatgrass, SERDP Recovery western wheatgrass, and SERDP Bozoisky-II parent Russian wildrye were reasonably covered. 
Table 12. Establishment and persistence of monocultures for 3 years at YTC Exit 11 (seeded 21-22 October 2002).

\begin{tabular}{|c|c|c|c|c|}
\hline Variety & 2003 & 2004 & 2005 & LSD @0.05 \\
\hline Russian wildrye (Bozoisky II) & 54 & 67 & 73 & ns \\
\hline Russian wildrye (Boz X Tet) & 47 & 60 & 62 & 12.33 \\
\hline Siberian wheatgrass (Vavilov II) & $52 *$ & $63 *$ & 73* & ns \\
\hline Siberian wheatgrass (Vavilov) & 23 & 35 & 51 & 9.33 \\
\hline Bluebunch wheatgrass (P-7) & 30 & 47 & 48 & ns \\
\hline Bluebunch wheatgrass (Goldar) & 32 & 39 & 40 & ns \\
\hline Slender wheatgrass (FirstStrike) & $82 *$ & 69 & 21 & 15.66 \\
\hline Slender wheatgrass (Pryor) & 49 & 48 & 28 & ns \\
\hline Snake River wheatgrass (SERDP) & 28 & 41 & 54 & 17.49 \\
\hline Snake River wheatgrass (Secar) & 40 & 58 & 54 & 13.87 \\
\hline Western wheatgrass (Recovery) & $73 *$ & $81 *$ & $80 *$ & ns \\
\hline Western wheatgrass (Rosana) & 40 & 53 & 59 & ns \\
\hline LSD @ 0.05 & 16.36 & 27.06 & 19.29 & \\
\hline
\end{tabular}

* significantly better than the equivalent standard cultivar in that year

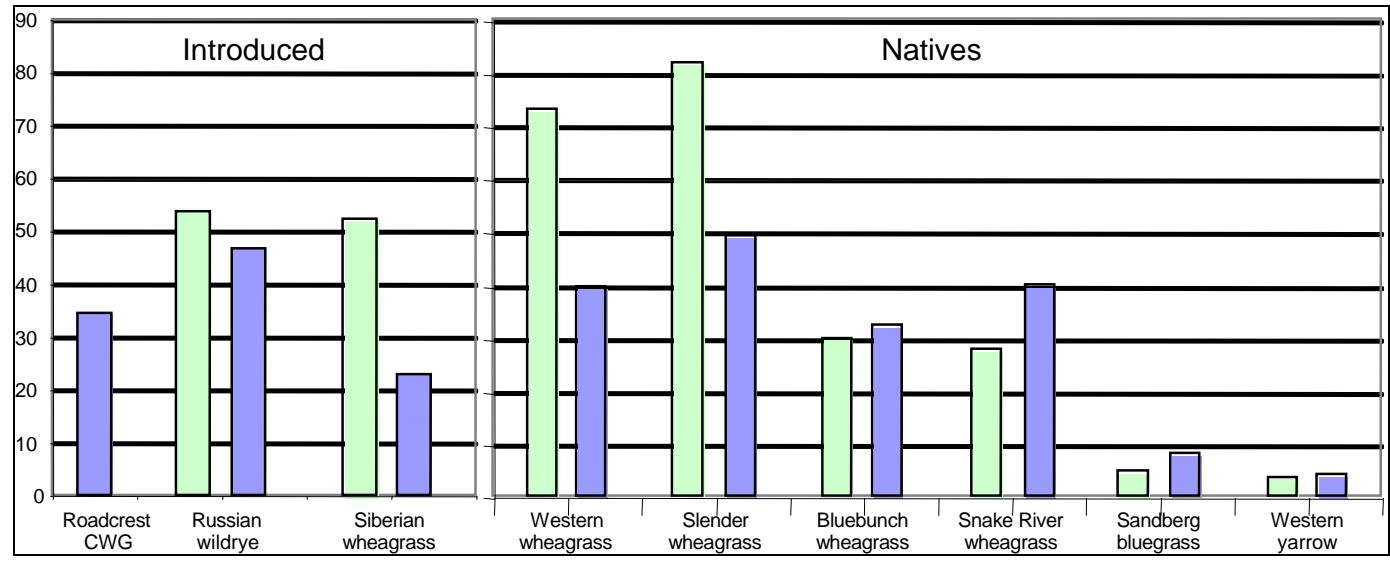

Figure 12. Percent establishment of modified germplasms (green) vs. standard cultivars at Exit 11 YTC in May 2003, 6 months after seeding. 


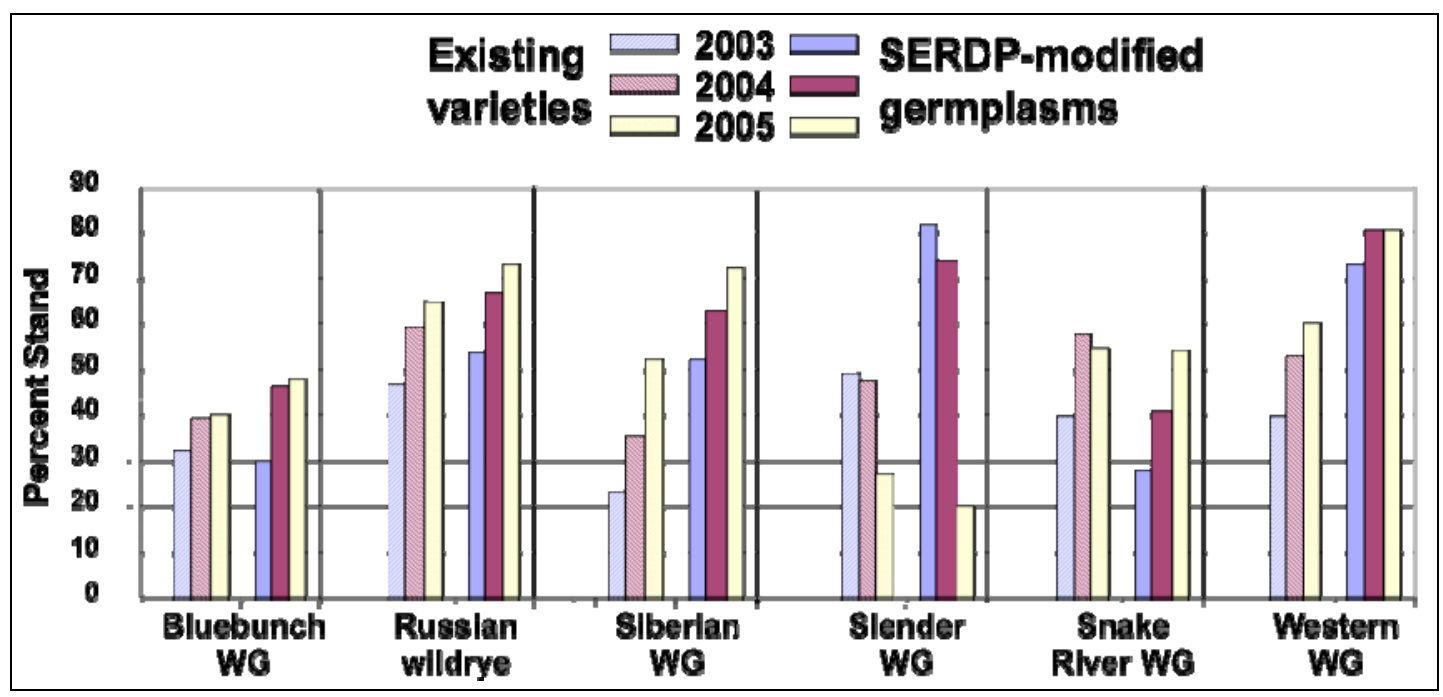

Figure 13. Percent stand vegetation from 2003 to 2005 (before June 2005 tracking at YTC).

\subsubsection{Camp Guernsey monocultures}

Camp Guernsey establishment (2 months after seeding). The River site was seeded 31 March 2004, and establishment measurements were taken 2 June 2004. The Tower site was seeded the following year on 23 March 2005, and establishment measurements were taken 2 June 2005. A 48-grid frame was used to count the number of the $6.35 \times 6.35-\mathrm{cm}$ (2.5 x 2.5-in.) squares that were missing plants. Stand frequency was then determined from the mean percentage of squares containing plants.

Our FirstStrike slender wheatgrass established significantly better than Pryor slender wheatgrass at both sites, and our Bozoisky II Russian wildrye established significantly better than the standard Bozoisky cultivar at the River site (Table 13). 
Table 13. Camp Guernsey site establishment data at two sites taken 2 months after seeding

(River site seeded 31 March 2004, data taken 2 June 2004;

Tower site seeded 23 March 2005, data taken 2 June 2005).

\begin{tabular}{|lrr|}
\hline Entry & $\begin{array}{c}\text { River } \\
\text { \% stand } \\
\text { at 2 mos. }\end{array}$ & $\begin{array}{c}\text { Tower } \\
\text { \% stand } \\
\text { at 2 mos. }\end{array}$ \\
\hline Introduced & $48^{*}$ & 50 \\
Russian wildrye (Bozoisky-II parent) & 17 & 65 \\
Russian wildrye (Bozoisky) & 54 & 68 \\
Siberian wheatgrass (Vavilov II) & 38 & 65 \\
Siberian wheatgrass (Vavilov) & & \\
Native & 61 & 51 \\
Western wheatgrass (Recovery) & 55 & 39 \\
Western wheatgrass (Rosana) & $81 *$ & $62 *$ \\
Slender wheatgrass (FirstStrike) & 35 & 37 \\
Slender wheatgrass (Pryor ) & 43 & 56 \\
Bluebunch wheatgrass (P-7) & 47 & 55 \\
Bluebunch wheatgrass (Goldar) & 5 & 55 \\
Snake River wheatgrass (SERDP-select) & 6 & 44 \\
Snake River wheatgrass (Secar) & 11 & 40 \\
Basin wildrye (SERDP-select) & 13 & 50 \\
Basin wildrye (Trailhead Basin) & 0 & 0 \\
Western Yarrow (Yakima) & 0 & 0 \\
Western Yarrow (Check) & 19 & 24 \\
\hline
\end{tabular}

* Significantly better than equivalent standard cultivar

\section{Camp Guernsey persistence data (1 year and 2 years after} seeding). Table 14 shows the 1-year data from both River and Tower sites; Table 15 shows 2-year data for the River site. We were unable to measure the Tower site after 2 years (2007) due to drought conditions. The 1-year percent stand at the River site was measured with a 24-grid frame of $12.7 \times 12.7-\mathrm{cm}$ ( $5 \times 5$-in.) squares; both visual ratings and frame data were taken for the remaining data.

After 1 year, our Bozoisky II Russian wildrye again had significant greater stand and fewer weeds than did the standard Bozoisky cultivar. After 1 and 2 years at the River site, our FirstStrike slender wheatgrass had significantly fewer weeds than did Pryor slender wheatgrass; after 2 years, FirstStrike had a significantly greater stand frequency than Pryor. 
Table 14. Camp Guernsey site persistence data at two sites taken 1 year after seeding (River site seeded 31 March 2004, data taken 2 June 2005;

Radar site seeded 23 March 2005, data taken 19 July 2006).

\begin{tabular}{|c|c|c|c|c|}
\hline \multirow[b]{2}{*}{ Entry } & \multicolumn{2}{|c|}{$\begin{array}{l}\text { River site at } 1 \mathrm{yr} \\
\text { (mean percent) }\end{array}$} & \multicolumn{2}{|c|}{$\begin{array}{l}\text { Tower site at } 1 \mathrm{yr} \\
\text { (mean percent) }\end{array}$} \\
\hline & Stand & $\begin{array}{l}\text { Seeds } \\
\text { (visual } \\
\text { estimate) }\end{array}$ & Stand & $\begin{array}{l}\text { Weeds } \\
\text { (visual } \\
\text { est.) }\end{array}$ \\
\hline \multicolumn{5}{|l|}{ Introduced } \\
\hline Russian wildrye (Bozoisky-II parent) & $61 *$ & $30 *$ & 81 & 3 \\
\hline Russian wildrye (Bozoisky) & 26 & 75 & 82 & 1 \\
\hline Siberian wheatgrass (Vavilov II) & 68 & 2 & 91 & 4 \\
\hline Native ${ }^{\text {Siberian wheatgrass (Vavilov) }}$ & 63 & 2 & 77 & 3 \\
\hline Western wheatgrass (Recovery) & 73 & 30 & 74 & 7 \\
\hline Western wheatgrass (Rosana) & 77 & 30 & 78 & 3 \\
\hline Slender wheatgrass (FirstStrike) & 65 & $17 *$ & 89 & 1 \\
\hline Slender wheatgrass (Pryor) & 44 & 50 & 65 & 4 \\
\hline Bluebunch wheatgrass (P-7) & 55 & 40 & 76 & 3 \\
\hline Bluebunch wheatgrass (Goldar) & 38 & 37 & 81 & 2 \\
\hline Snake River wheatgrass (SERDP-select) & 13 & 77 & 80 & 4 \\
\hline Snake River wheatgrass (Secar) & 8 & 73 & 70 & 6 \\
\hline Basin wildrye (SERDP-select) & 10 & 78 & 19 & 14 \\
\hline Basin wildrye (Trailhead Basin) & 10 & 77 & 25 & 10 \\
\hline Western yarrow (Yakima) & 0 & 90 & 1 & 22 \\
\hline Western yarrow (common variety) & 0 & 87 & 3 & 22 \\
\hline LSD @0.05 & 26.8 & 26.7 & 26.7 & 7.9 \\
\hline
\end{tabular}

* Significantly better than equivalent standard cultivar 
Table 15. Camp Guernsey River site persistence data 2 years after seeding (seeded 31 March 2004; data taken 19 July 2006).

\begin{tabular}{|c|c|c|c|c|c|}
\hline Entry & Cover & n percen & visual $r$ & $\begin{array}{l}\text { Bare } \\
\text { ground }\end{array}$ & $\begin{array}{c}\text { Frame } \\
\text { measure- } \\
\text { ment } \\
\text { percent } \\
\text { stand }\end{array}$ \\
\hline \multicolumn{6}{|l|}{ Introduced } \\
\hline Russian wildrye (Bozoisky-II parent) & 37 & 0 & 28 & 35 & $66 *$ \\
\hline Russian wildrye (Bozoisky) & 24 & 4 & 21 & 51 & 32 \\
\hline Siberian wheatgrass (Vavilov II) & 41 & 1 & 20 & 39 & 68 \\
\hline Siberian wheatgrass (Vavilov) & 38 & 1 & 16 & 46 & 55 \\
\hline \multicolumn{6}{|l|}{ Native } \\
\hline Western wheatgrass (Recovery) & 44 & 1 & 23 & 31 & 91 \\
\hline Western wheatgrass (Rosana) & 40 & 1 & 25 & 34 & 83 \\
\hline Slender wheatgrass (FirstStrike) & 37 & $1 *$ & 19 & 43 & $62 *$ \\
\hline Slender wheatgrass (Pryor) & 14 & 19 & 32 & 34 & 31 \\
\hline Bluebunch wheatgrass (P-7) & 28 & 5 & 26 & 41 & 50 \\
\hline Bluebunch wheatgrass (Goldar) & 24 & 7 & 19 & 50 & 43 \\
\hline $\begin{array}{l}\text { Snake River wheatgrass (SERDP- } \\
\text { select) }\end{array}$ & 7 & 26 & 27 & 41 & 14 \\
\hline Snake River wheatgrass (Secar) & 14 & 13 & 32 & 41 & 23 \\
\hline Basin wildrye (SERDP-select) & 3 & 29 & 22 & 46 & 6 \\
\hline Basin wildrye (Trailhead Basin) & 13 & 28 & 25 & 33 & 12 \\
\hline Western yarrow (Yakima) & 0 & 35 & 32 & 33 & 3 \\
\hline Western yarrow (common variety) & 0 & 36 & 31 & 34 & 0 \\
\hline LSD @0.05 & 16.5 & 17.3 & ns & ns & 29.8 \\
\hline
\end{tabular}

* Significantly better than equivalent standard cultivar

\subsubsection{Dugway Proving Ground monocultures}

We took establishment data only at DPG. The establishment was poor across all species at this very dry facility, so no further data were collected. The site was seeded 7 November 2005, and the establishment data taken 10 May 2006. Percent cover was obtained with a 48-grid frame with $6.35 \times 6.35-\mathrm{cm}$ (2.5 x 2.5-in.) squares. Establishment was poor overall, and the only significant differences between entries of the same species were for Siberian wheatgrass and slender wheatgrass (Table 16). 
Table 16. Dugway Proving Ground establishment data 6 months after seeding (seeded 7 November 2005; data taken 10 May 2006).

\begin{tabular}{|lc|}
\hline Entry & $\begin{array}{c}\text { Percent } \\
\text { stand }\end{array}$ \\
\hline Introduced & 15.5 \\
Russian wildrye (Bozoisky-II) & 17.9 \\
Russian wildrye (Bozoisky) & $33 .{ }^{*}$ \\
Siberian wheatgrass (Vavilov II) & 17.9 \\
\hline Siberian wheatgrass (Vavilov) & \\
Native & 11.6 \\
Western wheatgrass (Recovery) & 6.9 \\
Western wheatgrass (Rosana) & 11.8 \\
Slender wheatgrass (FirstStrike) & 23.3 \\
Slender wheatgrass (Pryor ) & 12.5 \\
Bluebunch wheatgrass (P-7) & 4.9 \\
Bluebunch wheatgrass (Goldar) & 9.4 \\
Snake River wheatgrass (BCO4) & 8.2 \\
Snake River wheatgrass (Secar) & 6.9 \\
Basin wildrye (SERDP-select) & 7.6 \\
Basin wildrye (Trailhead Basin) & 0.3 \\
Western yarrow (Yakima) & 0.0 \\
\hline Western yarrow (common variety) & 7.7 \\
\hline
\end{tabular}

* significantly greater than the equivalent standard cultivar

\subsubsection{Ecological-bridge demonstration (mixtures) - results}

We were able to obtain 4 years of data on mixtures only at the Fort Drum Airport site. Our mixture evaluations at YTC and Camp Guernsey were hampered by severe drought conditions, and our second Fort Drum site was trained on after the first year.

\subsubsection{Yakima Training Center mixes}

The following data (Table 17) were obtained for mixes planted at YTC in October 2002. See Table 5 for a list of the plants included in each mixture. There were no significant differences in the two mixtures in each year after seeding. 
Table 17. YTC mixtures approximately 6 months, 1.5 years, and 2.5 years after seeding.

\begin{tabular}{|lccc|}
\hline Mixture & $\begin{array}{c}\text { Mean percent } \\
\text { stand } \\
\text { (May 2003) }\end{array}$ & $\begin{array}{c}\text { Mean percent } \\
\text { stand } \\
\text { (April 2004) }\end{array}$ & $\begin{array}{c}\text { Mean percent } \\
\text { stand } \\
\text { (June 2005) }\end{array}$ \\
\hline Mix 1 - Introduced/native & 44 & 55 & 59 \\
Mix 2 - All native & 44 & 58 & 58 \\
\hline
\end{tabular}

\subsubsection{Camp Guernsey mixes}

The following data were obtained for the River Site at Camp Guernsey planted 31 March 2004. See Table 5 and Table 6 for lists of the plants included in each mixture.

At the River site (Table 18), the core native mix with our Bozoisky II Russian wildrye (mix 7) appeared to do the best overall for percent stand and inhibition of weeds, although there were no significant differences in establishment or weed control after the establishment year. The standard Guernsey mix 3 had significantly lower establishment than all the other mixes, which had no significant differences among them. 
Table 18. Camp Guernsey River site mixtures 2 months and 1 and 2 years after seeding (seeded 31 March 2004).

\begin{tabular}{|c|c|c|}
\hline Mixture & $\begin{array}{l}\text { Mean } \\
\text { percent } \\
\text { stand }\end{array}$ & $\begin{array}{l}\text { Mean } \\
\text { percent } \\
\text { weeds }\end{array}$ \\
\hline \multicolumn{3}{|l|}{ June 2, 2004 (2 months after seeding) } \\
\hline Mix 1 - Introduced / native & 42 & \\
\hline Mix 2 - All native & 51 & \\
\hline Mix 3 - Guernsey & 16 & \\
\hline Mix 4 - Core native & 55 & \\
\hline Mix 5 - Core + Al Intermediate wheatgrass & 54 & \\
\hline Mix 6 - Core + Vavilov II Siberian wheatgrass & 58 & \\
\hline Mix 7 - Core + Bozoisky II Russian wildrye & 57 & \\
\hline LSD @ 0.05 & 19.8 & \\
\hline \multicolumn{3}{|l|}{ June 2, 2005 (1 year after seeding) } \\
\hline Mix 1 - Introduced / native & 63 & 17 \\
\hline Mix 2 - All native & 76 & 30 \\
\hline Mix 3 - Guernsey & 41 & 45 \\
\hline Mix 4 - Core native & 63 & 37 \\
\hline Mix 5 - Core + Al Intermediate wheatgrass & 73 & 22 \\
\hline Mix 6 - Core + Vavilov II Siberian wheatgrass & 48 & 32 \\
\hline Mix 7 - Core + Bozoisky II Russian wildrye & 71 & 17 \\
\hline LSD@ 0.05 & ns & ns \\
\hline \multicolumn{3}{|l|}{ June 2006 (2 years after seeding) (Visual ratings) } \\
\hline Mix 1 - Introduced / native & 35 & 2 \\
\hline Mix 2 - All native & 26 & 14 \\
\hline Mix 3 - Guernsey & 41 & 4 \\
\hline Mix 4 - Core native & 37 & 4 \\
\hline Mix 5 - Core + Al Intermediate wheatgrass & 26 & 2 \\
\hline Mix 6 - Core + Vavilov II Siberian wheatgrass & 34 & 5 \\
\hline Mix 7 - Core + Bozoisky II Russian wildrye & 43 & 0 \\
\hline LSD @ 0.05 & ns & ns \\
\hline
\end{tabular}

At the Tower site (Table 19), the introduced-native mix tested at YTC provided the best stand both initially and after 1 year. After 1 year, the introduced-native mix 1 was significantly better than both the native-only mix 2 and the Guernsey mix 3. The standard Guernsey mix 3 had a significantly lower stand than all the other mixes after 1 year. There were very few weeds with any of the mixes and no significant differences among the mixes. The decrease across all mixes in 2006 may have reflected the 
beginning of drought; because of severe dryness, we were unable to obtain any data in 2007.

Table 19. Camp Guernsey Tower site mixtures 2 months and 1 year after seeding (seeded 23 March 2005).

\begin{tabular}{|c|c|c|c|}
\hline Mixture & & $\begin{array}{l}\text { Mean } \\
\text { percent } \\
\text { stand }\end{array}$ & $\begin{array}{l}\text { Mean } \\
\text { percent } \\
\text { weeds }\end{array}$ \\
\hline \multicolumn{4}{|l|}{ June 2, 2005 (2 months after seeding) } \\
\hline Mix 1 - Introduced / native & & 57 & \\
\hline Mix 2 - All native & & 50 & \\
\hline Mix 3 - Guernsey & & 25 & \\
\hline Mix 4 - Core native & & 47 & \\
\hline Mix 5 - Core + Al Intermediate wheatgrass & & 42 & \\
\hline Mix 6 - Core + Vavilov II Siberian wheatgrass & & 44 & \\
\hline Mix 7 - Core + Bozoisky II Russian wildrye & & 45 & \\
\hline & LSD @ 0.05 & ns & \\
\hline \multicolumn{4}{|c|}{ June 2006 (1 year after seeding) (Visual estimates) } \\
\hline Mix 1 - Introduced / native & & 28 & 4 \\
\hline Mix 2 - All native & & 17 & 5 \\
\hline Mix 3 - Guernsey & & 9 & 5 \\
\hline Mix 4 - Core native & & 23 & 4 \\
\hline Mix 5 - Core + Al Intermediate wheatgrass & & 19 & 4 \\
\hline Mix 6 - Core + Vavilov II Siberian wheatgrass & & 24 & 4 \\
\hline Mix 7 - Core + Bozoisky II Russian wildrye & & 17 & 7 \\
\hline & LSD@ @ 0.05 & 10.6 & ns \\
\hline
\end{tabular}

\subsubsection{Fort Drum mixes}

We took data at the Airport site for 4 years after the 22 May 2002 seeding, but were only able to obtain data at the Area 8 site for 1 year. The Area 8 site had a good plant cover after the first year and was used for training after that.

Even after 1 year (Table 20; Table 52 in Appendix D.7), the native switchgrass was doing very well, especially on the Area 8 site; the fescues were also doing well. The weeping lovegrass was beginning to die back at both sites. The hairgrasses established in only one plot (plot 4 with weeping lovegrass and switchgrass at Area 8). 
Table 20. Fort Drum Area 8: 1-year site percent cover and bare ground on 24 June 2003.

\begin{tabular}{|c|c|c|c|c|c|c|c|c|c|}
\hline & Treatment & WL & $\mathrm{FF}$ & SG & $H G$ & $\begin{array}{l}\text { Total } \\
\text { sown } \\
\text { species }\end{array}$ & $\begin{array}{c}\text { Other } \\
\text { species }\end{array}$ & $\begin{array}{l}\text { Dead } \\
\text { WL }\end{array}$ & $\begin{array}{l}\text { Bare } \\
\text { ground }\end{array}$ \\
\hline 1 & $\begin{array}{l}\text { Weeping } \\
\text { lovegrass }\end{array}$ & 16 & - & -- & -- & 16 & 1 & 77 & 6 \\
\hline 2 & $\begin{array}{l}\text { Weeping } \\
\text { lovegrass + } \\
\text { hairgrass }\end{array}$ & 19 & - & - & 0 & 19 & 42 & 35 & 4 \\
\hline 3 & $\begin{array}{l}\text { Weeping } \\
\text { lovegrass + } \\
\text { switchgrass }\end{array}$ & 6 & - & 83 & -- & 88 & 0 & 11 & 1 \\
\hline 4 & $\begin{array}{l}\text { Weeping } \\
\text { lovegrass + } \\
\text { switchgrass + } \\
\text { hairgrass }\end{array}$ & 1 & - & 83 & 4 & 87 & 0 & 12 & 0 \\
\hline 5 & $\begin{array}{l}\text { Weeping } \\
\text { lovegrass + } \\
\text { hairgrass + } \\
\text { switchgrass + } \\
\text { fine fescues }\end{array}$ & 0 & 42 & 2 & 0 & 44 & 0 & 44 & 2 \\
\hline 6 & $\begin{array}{l}\text { Weeping } \\
\text { lovegrass + } \\
\text { hairgrasses + } \\
\text { fine fescues }\end{array}$ & 5 & 10 & - & 0 & 17 & 70 & 9 & 4 \\
\hline 7 & $\begin{array}{l}\text { Weeping } \\
\text { lovegrass + } \\
\text { switchgrass + } \\
\text { fine fescues }\end{array}$ & 4 & 62 & 2 & -- & 64 & 0 & 33 & 2 \\
\hline \multirow[t]{2}{*}{8} & $\begin{array}{l}\text { Weeping } \\
\text { lovegrass + } \\
\text { fine fescues }\end{array}$ & 54 & 18 & -- & -- & 58 & 0 & 42 & 0 \\
\hline & LSD @ 0.05 & 17 & 24 & 15 & $\mathrm{~ns}$ & 23 & 13 & 20 & ns \\
\hline
\end{tabular}

Detailed data with statistics for the 4 years (2003-2006) at the Fort Drum airport site are shown in Appendix Section D.7. The weeping lovegrass had died off in all plots and the fescues were doing well in all plots where it was sown; the native hairgrass failed in all plots. Percentages of undesired (other) species were low in all plots except plot 2, which was sown with weeping lovegrass with hairgrass, both of which had died off. Figure 14 separates the results for the four plots $(3,4,5$, and 7$)$ that contained switchgrass. After 4 years, the switchgrass was doing significantly better in those plots that did not contain fescues ( 3 and 4). In summary, the nurse 
crop did well during the initial year after seeding but was no longer competitive after 2 years; stands of predominately switchgrass or fescues were created, giving a choice for the desired goal-a tall native stand or a lower growing more fire resistant stand of fescues.

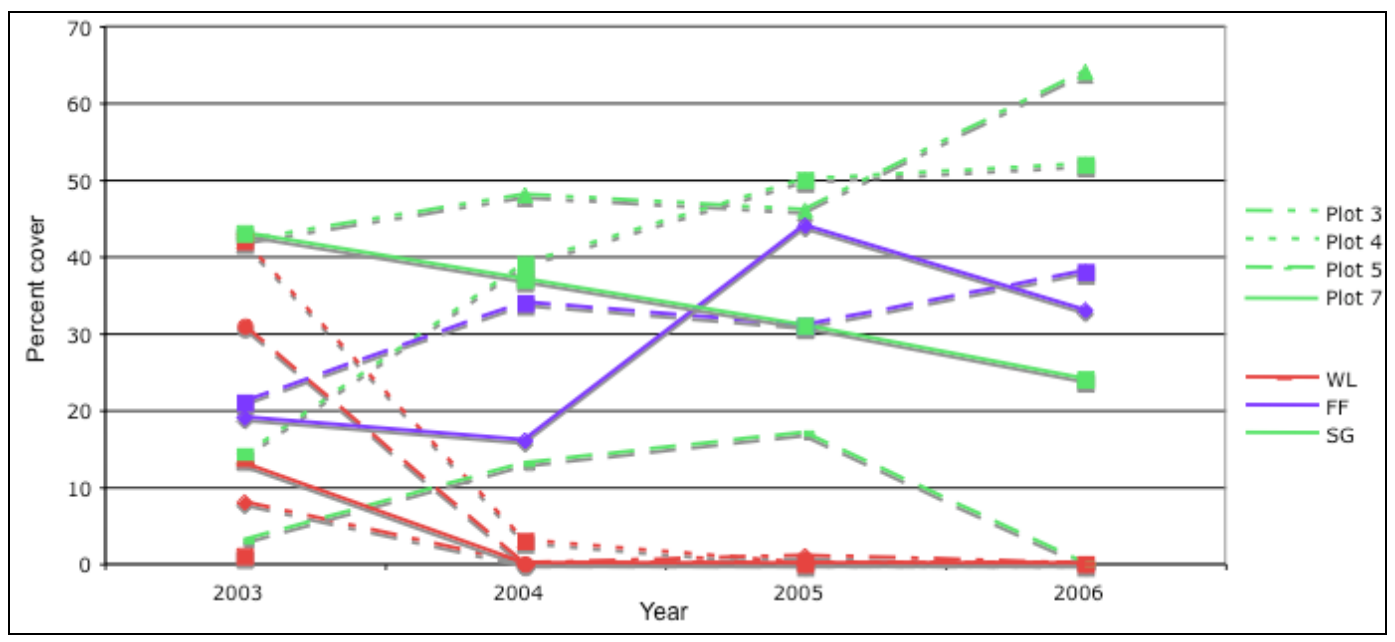

Figure 14. Airport site percent cover on the four plots seeded with switchgrass (see Table 7 for seeding mixtures).

\subsubsection{Military traffic on monocultures at YTC - results}

Plots at YTC were tracked with o, 1, or 4 passes in June 2005. Soil and vegetation data were taken immediately before and after tracking as well as 1 and 2 years later (June 2006 and 2007).

\subsubsection{Soil data}

There were no significant differences in soil compaction by plant entry (Table 55 in Appendix Section D.8). Overall, increased tracking significantly decreased the soil strength and compaction immediately after the tracking (Figure 15 and Table 21); tracking with a Stryker was similar to a tillage operation causing the soil to be fluffier with increasing passes. Shear vane measurements could not be taken immediately after tracking because of the soil disturbance. In succeeding years, any differences in soil compaction between treatments were slight, and the cone penetrometer values for the 4-pass treatment were essentially the same as the control (opass). 


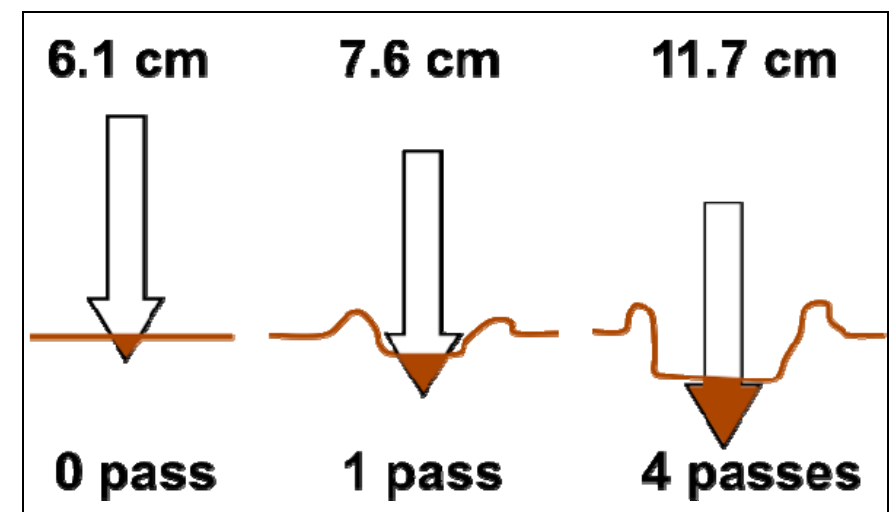

Figure 15. Mean soil compaction results in ruts immediately after June 2005 tracking at YTC (the deeper the penetrometer depth, the less compact the soil).

There was a significant increase in soil moisture in 2006 due to unexpectedly high rainfall (Table 21). The cone penetrometer data showed significantly decreased soil compaction along with the increased soil moisture. By the following year, the soil was more compact, with values very close to those for 2005 .

Table 21. Overall soil properties over 3 years after tracking in June 2005.

\begin{tabular}{|lccccccccc|}
\hline & & \multicolumn{4}{c}{ Shear vane $(\mathrm{kPa})$} & \multicolumn{4}{c|}{ Cone penetrometer (cm) } \\
Year & $\begin{array}{c}\text { Soil } \\
\text { moisture (\%) }\end{array}$ & $\begin{array}{c}0 \\
\text { pass }\end{array}$ & $\begin{array}{c}1 \\
\text { pass }\end{array}$ & $\begin{array}{c}4 \\
\text { pass }\end{array}$ & $\begin{array}{c}\text { LSD } \\
\text { @0.05 }\end{array}$ & $\begin{array}{c}0 \\
\text { pass }\end{array}$ & $\begin{array}{c}1 \\
\text { pass }\end{array}$ & $\begin{array}{c}4 \\
\text { pass }\end{array}$ & @0.05 \\
\hline 2005 & 2.8 & 38.8 & -- & -- & -- & 6.1 & 7.6 & 11.7 & 0.5 \\
2006 & 14.3 & 38.1 & 36.4 & 24.6 & ns & 13.4 & 12.1 & 13.0 & 0.4 \\
2007 & 3.3 & 37.6 & 35.8 & 24.1 & ns & 7.5 & 7.1 & 7.5 & 0.2 \\
\hline LSD @ 0.05 & 0.1 & ns & .55 & ns & & 0.5 & 0.4 & 0.5 & \\
\hline
\end{tabular}

Rut depth profiles did not differ significantly in the years following tracking, but mean rut depth $(7 \mathrm{~cm})$ after the 4-pass treatment was significantly different than for the 1-pass treatment $(4.2 \mathrm{~cm})$ for all entries (Table 56 in Appendix Section D.8). The modified cultivars of Siberian wheatgrass, slender wheatgrass and Snake River wheatgrass had significantly lower rutting at 1-pass treatment than their market competitors. Likewise the modified cultivars of Siberian wheatgrass, Russian wildrye, slender wheatgrass, and western wheatgrass had significantly lower rutting than their market counterparts at the 4-pass treatment. The decreased rutting at 1- and 4-pass treatments indicates 
better root structure and resiliency than the other cultivar (See Table 56 in Appendix D.8).

The mean value for soil bulk density (taken in o-pass treatments in 2005) was $1.098 \mathrm{~g} / \mathrm{cm}^{3}$.

\subsubsection{Vegetation data}

A summary of all plant cover data for the 3 years shows that each level of tracking was significantly different (Table 22). Similarly, there were significant differences in overall plant cover each year, showing the impact of heavy rains in 2006. The percentage of cover jumps from $38.7 \%$ to $51.3 \%$ (for all varieties and tracking levels combined), and then goes down to $44.4 \%$ for 2007 . This effect is mirrored in soil moisture data (Table 21).

Table 22. Summary data for tracking and annual effects on plant cover at YTC.

\begin{tabular}{|lc|lc|}
\hline \multicolumn{2}{|c|}{ Tracking effect } & \multicolumn{2}{c|}{ Yearly effect } \\
Tracking & \% Cover & Year & \% Cover \\
\hline 0 pass & 51.1 & 2005 & 38.7 \\
1 pass & 26.4 & 2006 & 51.3 \\
4 passes & 4.28 & 2007 & 44.4 \\
\hline LSD @ 0.05 & 5.11 & LSD @ 0.05 & 4.28 \\
\hline
\end{tabular}

Vegetative cover in the 3 years leading up to tracking is shown above in Section 5.6.1.1 (Table 12, Figure 12, and Figure 13). The SERDP-modified entries generally did better than the standard cultivars; the SERDP cultivars of Siberian wheatgrass and western wheatgrass had significantly better cover than their counterparts in all 3 years before tracking.

Throughout the post-tracking evaluations, three SERDP-modified entries-Snake River wheatgrass, Siberian wheatgrass, and Russian wildrye-performed better than the standard variety counterparts. Figure 16 compares the plant varieties for all tracking treatments combined immediately after and 1 year following tracking, and Table 23 shows the same comparisons for the duration of the tracking evaluation (20052007). Of note overall is the SERDP Snake River wheatgrass (74.1\%) versus Secar Snake River wheatgrass (48.9\%) and SERDP Siberian wheatgrass Vavilov II (72.5\%) versus the standard Vavilov (45.5\%). Both 
slender wheatgrass entries were low throughout, likely because of poor performance in the dry conditions preceding the tracking event.

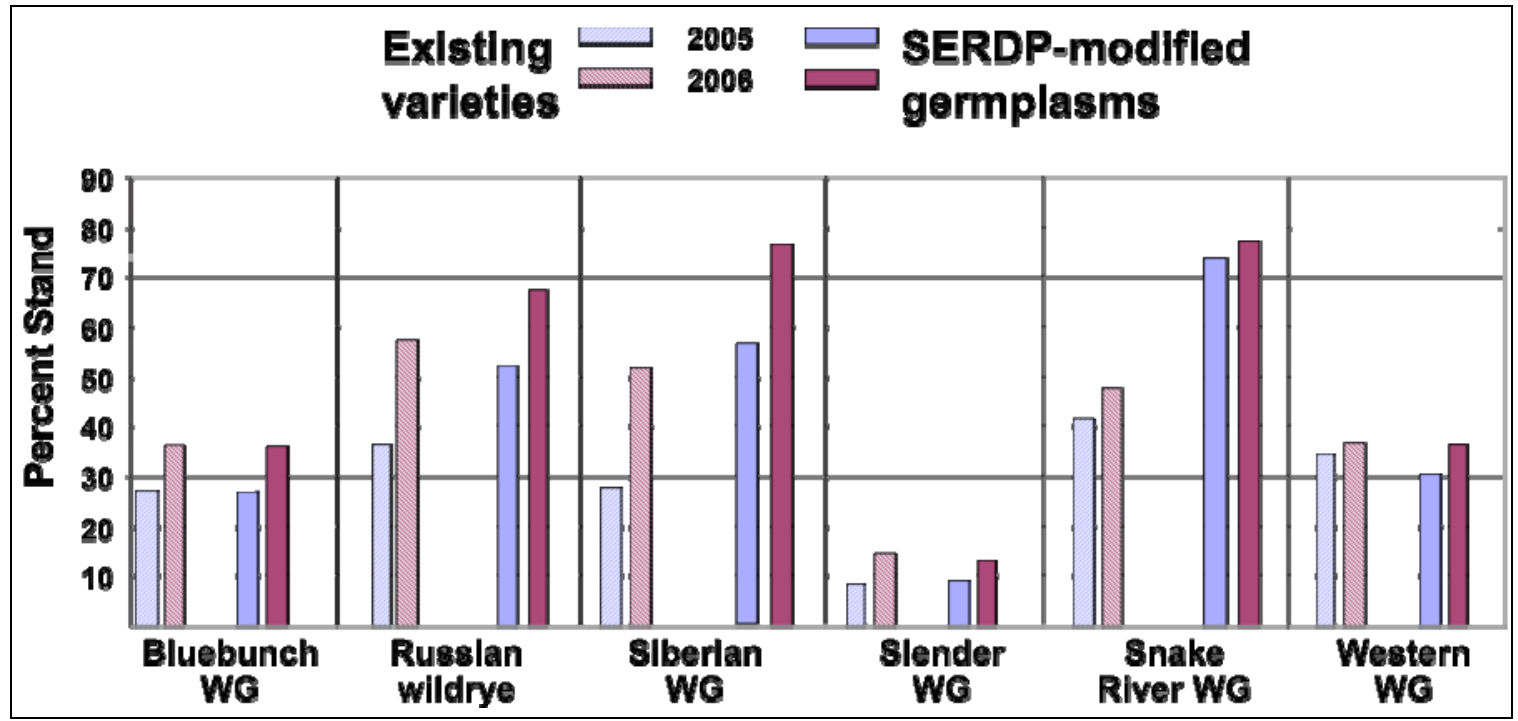

Figure 16. Percentage stand for vegetation immediately after and 1 year following 2005 tracking at YTC (Figure 13 shows percentage stand for 2003-2005 before tracking).

Table 23. Summary of plant cover for each entry at YTC over all treatments for 3 years after tracking (2005-2007).

\begin{tabular}{|lc|}
\hline Entry & \% Cover \\
\hline Bluebunch wheatgrass (P-7) & 36.6 \\
Bluebunch wheatgrass (Goldar) & 34.1 \\
\hline Russian wildrye (Bozoisky II) & $59.7^{*}$ \\
Russian wildrye (BozXTet) & 43.7 \\
\hline Siberian wheatgrass (Vavilov II) & $72.5^{*}$ \\
Siberian wheatgrass (Vavilov) & 45.4 \\
\hline Slender wheatgrass (FirstStrike) & 12.6 \\
Slender wheatgrass (Pryor) & 13.5 \\
\hline Snake River wheatgrass (SERDP) & $74.1^{*}$ \\
Snake River wheatgrass (Secar) & 48.9 \\
\hline Western wheatgrass (Recovery) & 43.7 \\
Western wheatgrass (Rosana) & 53.8 \\
\hline & 8.57 \\
\hline
\end{tabular}

Significantly greater than the standard cultivar entry for this species. 
Looking at tracking effects, all entries (except for Pryor slender wheatgrass) had significantly less cover at the 4-pass treatment as compared to the 1-pass treatment (Table 24). Most entries had no significant difference in cover between the no-pass control and 1-pass treatment. Three of the SERDP-modified entries-Bozoisky II Russian wildrye, Vavilov II Siberian wheatgrass, and SERDP-select Snake River wheatgrass-did significantly better than the commonly available varieties for all treatments.

Table 24. Varieties showing significant differences at the different tracking passes over 3 years of data (2005-2007) after tracking at YTC.

\begin{tabular}{|c|c|c|c|c|}
\hline \multirow[b]{2}{*}{ Entry } & \multicolumn{3}{|c|}{ Tracking } & \multirow[b]{2}{*}{ LSD @0.05 } \\
\hline & 0 pass & 1 pass & 4 pass & \\
\hline Bluebunch wheatgrass (P-7) & $63^{*}$ & 44.4 & 3.2 & 5.6 \\
\hline Bluebunch wheatgrass (Goldar) & 41.2 & 47.2 & 13.9 & 16.5 \\
\hline Russian wildrye (Bozoisky II) & $75.9^{*}$ & $63.9^{*}$ & $39.3^{*}$ & 15.8 \\
\hline Russian wildrye (BozXTet) & 49.5 & 55.1 & 26.4 & 15.1 \\
\hline Siberian wheatgrass (Vavilov II) & $81.5^{*}$ & $77.8^{*}$ & $58.3^{*}$ & 7.2 \\
\hline Siberian wheatgrass (Vavilov) & 61.6 & 59.3 & 15.3 & 8.3 \\
\hline Slender wheatgrass (FirstStrike) & 23.1 & 13.9 & 0.9 & 6.6 \\
\hline Slender wheatgrass (Pryor) & 17.1 & 13.9 & 9.7 & 8.6 \\
\hline Snake River wheatgrass (SERDP) & $78.2^{*}$ & $80.1^{*}$ & $63.9^{*}$ & 5.5 \\
\hline Snake River wheatgrass (Secar) & 56 & 57.4 & 33.3 & 9.7 \\
\hline Western wheatgrass (Recovery) & 64.8 & 48.6 & 17.6 & 6.9 \\
\hline Western wheatgrass (Rosana) & 71.7 & 51.4 & 35.2 & 10.9 \\
\hline LSD @ 0.05 & 10.4 & 9.4 & 9.1 & \\
\hline
\end{tabular}

* significantly better than the equivalent standard cultivar for that treatment

\subsubsection{Cultivar validation: germination and nursery-field studies - results}

\subsubsection{Germination studies}

In the growth-pouch germination studies, germination occurred at all the temperatures-10, $15,20,25$, and $30^{\circ} \mathrm{C}\left(33.8,59,68,77\right.$, and $\left.86^{\circ} \mathrm{F}\right)$-but there were significant differences between the lower and higher temperatures. The greatest percent germination occurred at $15{ }^{\circ} \mathrm{C}$; the next highest rates were at $10^{\circ} \mathrm{C}$ and $20^{\circ} \mathrm{C}$. Although germination 
occurred sooner at the higher temperatures, the percent germination was significantly lower at the two highest temperatures (Table 25).

Table 25. Temperature effects on all entries combined in germination growth pouch studies.

\begin{tabular}{|c|c|c|}
\hline Temperature & Average time to germination (days) & Percent germination \\
\hline $10^{\circ} \mathrm{C}$ & 6.4 & 70.9 \\
\hline $15^{\circ} \mathrm{C}$ & 5.7 & 76.2 \\
\hline $20^{\circ} \mathrm{C}$ & 4.6 & 68.7 \\
\hline $25^{\circ} \mathrm{C}$ & 4.8 & 58 \\
\hline $30{ }^{\circ} \mathrm{C}$ & 5.1 & 40.6 \\
\hline LSD @0.05 & 0.45 & 2.9 \\
\hline
\end{tabular}

Table 26 and Table 27 compare our four cultivars plus our modified Snake River wheatgrass (a potential cultivar) with currently available cultivars at the five temperature variables (green shading indicates our cultivars). FirstStrike slender wheatgrass germinated earlier than Pryor at the three lower temperatures. For the other species comparisons, there were no significant differences in time to germination at the individual temperatures (Table 26). 
Table 26. Species comparisons of average days to germination in growth pouch studies.

\begin{tabular}{|c|c|c|c|c|c|c|}
\hline \multirow[b]{2}{*}{ Entry } & \multicolumn{6}{|c|}{ Days to germination } \\
\hline & $10^{\circ} \mathrm{C}$ & $15^{\circ} \mathrm{C}$ & $20^{\circ} \mathrm{C}$ & $25^{\circ} \mathrm{C}$ & $30^{\circ} \mathrm{C}$ & $\begin{array}{c}\text { All } \\
\text { temps }\end{array}$ \\
\hline Russian wildrye (Bozoisky II) & 6.2 & 4.7 & 3.1 & 3.4 & 4.5 & 4.4 \\
\hline Russian wildrye (Bozoisky) & 5.7 & 5 & 3.2 & 3.2 & 4.6 & 4.3 \\
\hline LSD @ 0.05 & ns & ns & ns & ns & ns & ns \\
\hline Siberian wheatgrass (Vavilov II) & 4.9 & 4.3 & 3.5 & 3.4 & 4.2 & 4.1 \\
\hline Siberian wheatgrass (Vavilov) & 5.3 & 4.6 & 3.6 & 3.8 & 4.1 & 4.3 \\
\hline LSD @ 0.05 & ns & ns & ns & ns & ns & 0.18 \\
\hline Slender wheatgrass (FirstStrike) & 5.6 & 5 & 4.6 & 4.6 & 6.2 & 5.2 \\
\hline Slender wheatgrass (Pryor) & 11.6 & 11.6 & 10.3 & 7.1 & 0 & 8.1 \\
\hline LSD @ 0.05 & 2.3 & 0.1 & 2.8 & ns & 2 & 1.7 \\
\hline Snake River wheatgrass (SERDP) & 4.3 & 3.9 & 3.1 & 3.7 & 4.4 & 3.9 \\
\hline Snake River wheatgrass (Secar) & 4.5 & 4 & 4.1 & 5.1 & 5.3 & 4.6 \\
\hline LSD @ 0.05 & ns & ns & ns & ns & ns & 0.3 \\
\hline Western wheatgrass (Recovery) & 7 & 6 & 4.7 & 4.9 & 7.7 & 6.1 \\
\hline Western wheatgrass (Rosana) & 8.4 & 7.3 & 4.3 & 5.3 & 7.2 & 6.5 \\
\hline LSD @ 0.05 & ns & ns & ns & ns & ns & ns \\
\hline
\end{tabular}

For percent germination, our FirstStrike slender wheatgrass outperformed Pryor at all temperatures; both cultivars did poorly at the higher temperatures, but FirstStrike still outperformed Pryor. Our modified Snake River wheatgrass entry also outperformed Secar at all temperatures except $10^{\circ} \mathrm{C}$ where there was no significant difference between the two. For the remaining entries, our modified cultivars were the generally same or slightly better for percent germination than the standard cultivars, although Bozoisky Russian wildrye had significantly greater percent germination at $10^{\circ} \mathrm{C}$ than did our Bozoisky II entry and Rosana western wheatgrass outperformed Recovery at the higher temperatures (Table 27). 
Table 27. Species comparisons of average percent germination in growth pouch studies.

\begin{tabular}{|c|c|c|c|c|c|c|}
\hline \multirow[b]{2}{*}{ Entry } & \multicolumn{6}{|c|}{ Percent germination } \\
\hline & $10^{\circ} \mathrm{C}$ & $15^{\circ} \mathrm{C}$ & $20^{\circ} \mathrm{C}$ & $25^{\circ} \mathrm{C}$ & $30^{\circ} \mathrm{C}$ & $\begin{array}{c}\text { All } \\
\text { temps }\end{array}$ \\
\hline Russian wildrye (Bozoisky II) & 57.5 & 74 & 86 & 62 & 68.5 & 69.6 \\
\hline Russian wildrye (Bozoisky) & 92.5 & 96 & 88 & 95.2 & 78.5 & 89.5 \\
\hline LSD @ 0.05 & 24.7 & ns & ns & $\mathrm{ns}$ & ns & 6.4 \\
\hline Siberian wheatgrass (Vavilov II) & 95.5 & 93 & 96 & 94 & 77 & 91.1 \\
\hline Siberian wheatgrass (Vavilov) & 88.5 & 89 & 91 & 85 & 71 & 84.9 \\
\hline LSD @ 0.05 & ns & ns & ns & ns & ns & 3 \\
\hline Slender wheatgrass (FirstStrike) & 89 & 94 & 81 & 66.5 & 33.5 & 89 \\
\hline Slender wheatgrass (Pryor) & 38.5 & 50 & 14 & 3 & 1 & 38.5 \\
\hline LSD @ 0.05 & 14.3 & 3.7 & 16.5 & 14.5 & 28.7 & 14.3 \\
\hline Snake River wheatgrass (SERDP) & 90 & 93 & 90 & 86.5 & 61.5 & 84.2 \\
\hline Snake River wheatgrass (Secar) & 87 & 83 & 74 & 62.5 & 39 & 69.1 \\
\hline LSD @ 0.05 & ns & 8.1 & 11 & 10.7 & 18.1 & 4.2 \\
\hline Western wheatgrass (Recovery) & 38.5 & 59 & 36 & 12 & 4.5 & 30 \\
\hline Western wheatgrass (Rosana) & 31.5 & 43 & 31 & 36 & 18 & 31.9 \\
\hline LSD @ 0.05 & ns & 11 & ns & 20.3 & ns & ns \\
\hline
\end{tabular}

When all entries were compared together over all temperatures combined, three of our four modified native germplasms ranked in the top six for percent germination (Table 28). 
Table 28. Overall comparisons with all temperatures combined in germination growth pouch studies.

\begin{tabular}{|lccc|}
\hline Entry & $\begin{array}{c}\text { Average time to } \\
\text { germination (days) }\end{array}$ & $\begin{array}{c}\text { Percent } \\
\text { germination }\end{array}$ & $\begin{array}{c}\text { Percent } \\
\text { rank }\end{array}$ \\
\hline Basin Wildrye (SERDP) & 6.7 & 38.6 & \\
Great Basin Wildrye (Magnar) & 5.6 & 71.5 & 6 \\
\hline Russian Wildrye (Bozoisky II) & 4.4 & 69.6 & 2 \\
Russian Wildrye (Bozoisky) & 4.3 & 89.5 & 5 \\
\hline Slender wheatgrass (FirstStrike) & 5.2 & 72.8 & 4 \\
Slender wheatgrass (Pryor) & 8.1 & 21.3 & 1 \\
\hline Snake River wheatgrass (SERDP) & 3.9 & 84.2 & 3 \\
Snake River wheatgrass (Secar) & 4.6 & 69.1 & \\
\hline Siberian wheatgrass (Vavilov II) & 4.1 & 91.1 & \\
Siberian wheatgrass (Vavilov) & 4.3 & 84.9 & \\
\hline Western wheatgrass (Recovery) & 6.1 & 30 & \\
Western wheatgrass (Rosana) & 6.5 & 31.9 & \\
\hline & 0.7 & 4.6 & \\
\hline
\end{tabular}

\subsubsection{Space-planted nursery studies}

Data gathered in these trials were used, along with morphological and genetic characteristics, to support the releases of four cultivars under the ESTCP program. Nursery sites are described in Section 5.3.4 (Table 8).

Recovery western wheatgrass was selected for plant and seedling vigor, increased germination, and seed yield. During the spring of the establishment year, Recovery western wheatgrass had significantly higher $(\mathrm{P} \leq 0.05)$ frequency of seedlings (0.60) than parental/closely-related cultivars Rosana (0.48) and Rodan (0.45), and the western wheatgrass cultivars of Arriba (0.45), Barton (0.42), and Flintlock (0.53) when analyzed across all locations (Table 60 in Appendix Section D.9). Within locations, Recovery had significantly better establishment than Rodan in three of five test locations, and more than Rosana in three of eight test locations (Table 60 in Appendix Section D.9). On average, Recovery's establishment was better than Bozoisky Russian wildrye, similar to Bozoisky II and Vavilov Siberian wheatgrass, and lower than Vavilov II and Hycrest and Hycrest II crested wheatgrasses (Table 60 in Appendix Section D.9). 
Seedlings can have difficulties surviving the first year after planting due to competition from invasive annual and biennial grasses and forbs that benefit from the disturbed, open environment. Across locations, Recovery western wheatgrass had significantly $(\mathrm{P} \leq 0.05)$ more surviving plants (frequency of 0.77) the year after establishment than parental/closelyrelated cultivars Rosana (0.68) and Rodan (0.66), and the western wheatgrass cultivars of Arriba (o.63), Barton (o.68), and Flintlock (o.66) (Table 61 in Appendix D.9). In fact, Recovery had higher frequency ( $\mathrm{P} \leq$ 0.05) of plants than any other western wheatgrass cultivar until the fourth to sixth year after planting (Figure 17).

Forage yield (dry matter yield) of Recovery western wheatgrass was not significantly different than other western wheatgrass cultivars at the nursery sites at Blue Creek, UT and the Curlew Valley, ID with the exception of a higher yield than Rosana at Curlew Valley (Table 62 in Appendix Section D.9). However, at Nephi, UT, Recovery forage yield was significantly lower than all other western wheatgrass cultivars except Arriba (Table 62 in Appendix D.9). Overall, these results suggest that Recovery will yield comparable or slightly less than other western wheatgrasses. 


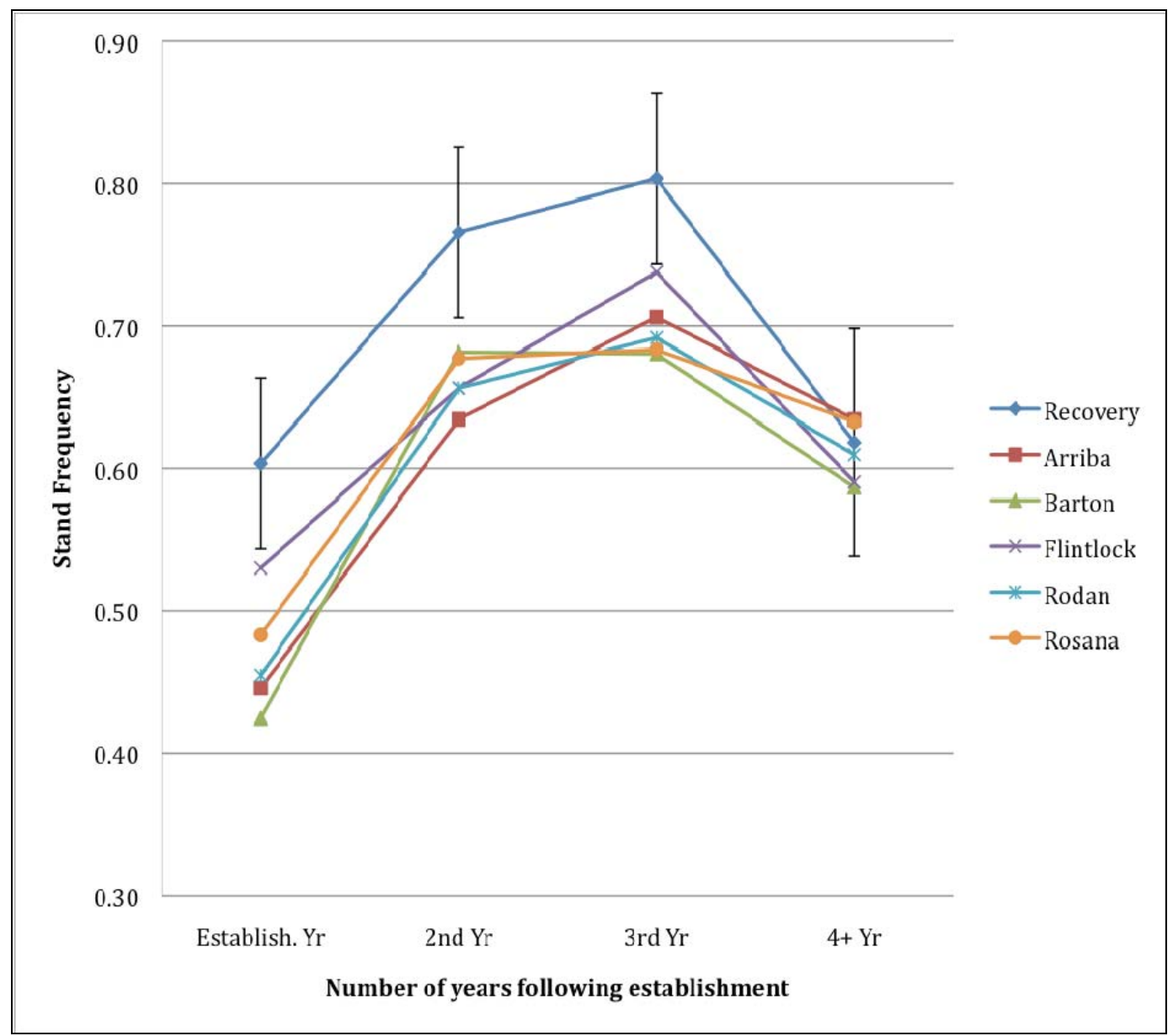

Figure 17. Stand of Recovery western wheatgrass as compared to standard western wheatgrass checks when evaluated at eight locations throughout the western United States Error bars are the $L S D$ value at the $P=0.05$ probability level. The " $4+Y r$ " category is the latest evaluation taken at a given site and ranges from 4-6 years after planting. (Waldron et al. in press).

FirstStrike slender wheatgrass was selected for persistence and overall plant vigor in response to drought. It had significantly $(\mathrm{P}<0.05)$ more seedlings per unit area $\left(\mathrm{m}^{2}\right)$ than Pryor in the establishment year (Table 13, Table 29, and Table 30). For nursery sites at Fillmore, Utah, and Malta, Idaho, initial stand and persistence of FirstStrike were similar to the cultivar San Luis. FirstStrike was similar to or better than Pryor and San Luis for persistence. At Guernsey, Wyoming, dry matter yield was 27\% greater $(\mathrm{P}<0.07)$ in FirstStrike than Pryor. FirstStrike germinated five days earlier than Pryor on three different soil types (sandy loam, loam, and sandy) than Pryor. 
Table 29. Stand establishment and persistence over 1 year at two Fillmore, Utah sites, established fall 2003 (Site 1) and 2004 (Site 2) (Jensen et al. 2007).

\begin{tabular}{|c|c|c|c|c|}
\hline \multirow[b]{2}{*}{ Entry } & \multicolumn{3}{|c|}{ Site 1 - \% Stand } & \multirow{2}{*}{$\begin{array}{c}\text { Site } 2- \\
\% \text { Stano } \\
\text { Estab. } \\
2005\end{array}$} \\
\hline & $\begin{array}{l}\text { Estab. } \\
2004\end{array}$ & $\begin{array}{l}\text { Persistence } \\
\quad 2005\end{array}$ & $\begin{array}{l}\text { Persistence } \\
\text { comb. 2004-05 }\end{array}$ & \\
\hline Siberian wheatgrass (Vavilov) & & & & 54 \\
\hline Siberian wheatgrass (Vavilov II) & & & & 79 \\
\hline Trailhead Basin wildrye & & & & 33 \\
\hline Snake River wheatgrass (Secar) & 38 & 55 & 47 & 41 \\
\hline $\begin{array}{l}\text { Snake River wheatgrass (SERDP } \\
\text { Select ) }\end{array}$ & 64 & 68 & 66 & 58 \\
\hline Bluebunch wheatgrass (Goldar) & 67 & 67 & 67 & 81 \\
\hline Bluebunch wheatgrass (P7) & 60 & 66 & 63 & 48 \\
\hline Slender wheatgrass (Pryor) & 34 & 44 & 39 & 50 \\
\hline Slender wheatgrass (San Luis ) & & & & $87^{*}$ \\
\hline Slender wheatgrass (FirstStrike) & $81^{*}$ & $90^{*}$ & $85^{*}$ & $78^{*}$ \\
\hline Western wheatgrass (Rosana) & 73 & 90 & 81 & 57 \\
\hline Western wheatgrass (Flintlock) & 84 & 83 & 84 & - \\
\hline Western wheatgrass (SB-2) & 88 & 89 & 89 & 67 \\
\hline Western wheatgrass (Recovery) & 49 & 74 & 69 & 62 \\
\hline LSD (0.05) & 21 & 20 & 18 & 21 \\
\hline
\end{tabular}

* FirstStrike was significantly better than the cultivar Pryor slender wheatgrass. 
Table 30. Stand establishment at Malta, Idaho site, established fall 2004 (Jensen et al. 2007).

\begin{tabular}{|lc|}
\hline Entry & $\begin{array}{c}\text { Establishment year 2005 } \\
\text { (\% Stand) }\end{array}$ \\
\hline Siberian wheatgrass (Vavilov) & 92 \\
Siberian wheatgrass (Vavilov II) & 95 \\
Snake River wheatgrass (Secar) & 79 \\
Snake River wheatgrass (SERDP Select ) & 85 \\
Bluebunch wheatgrass (Goldar) & 79 \\
Bluebunch wheatgrass (P7) & 88 \\
Slender wheatgrass (Pryor) & 36 \\
Slender wheatgrass (San Luis ) & 76 \\
Slender wheatgrass (FirstStrike) & $86^{*}$ \\
Western wheatgrass (Rosana) & 45 \\
Western wheatgrass (Barton) & 55 \\
Western wheatgrass (SB-2) & 68 \\
Western wheatgrass (Recovery) & $67^{\#}$ \\
LSD (0.05) & 13 \\
\hline
\end{tabular}

* FirstStrike was significantly better than the cultivar Pryor slender wheatgrass.

\# Recovery was significantly better than the cultivar Rosana western wheatgrass

Vavilov II Siberian wheatgrass was selected for seedling and vegetative vigor, seed yield and early spring green-up. During the establishment year, Vavilov II Siberian wheatgrass had significantly $(\mathrm{P}<0.05)$ higher numbers of seedlings per unit area $\left(\mathrm{m}^{2}\right)$ than Vavilov at YTC (52 vs. $23 \%$ ), Fillmore (79 vs. $54 \%$ ), DPG (79 vs. $52 \%$ ), and Curlew Valley (70 vs. 40\%) (Figure 18; Tables 63-66 in Appendix D.9). In persistence after establishment, as measured by percent stand, Vavilov II was significantly more persistent than Vavilov at YTC (68 vs. 44\%), Fillmore (84 vs. $62 \%$ ), Curlew Valley (69 vs. 55\%), and Malta (97 vs. 91\%) (Figure 19; Tables 63-66 in Appendix D.9). Dry matter yields (64 cm x $38 \mathrm{~cm}$ plot) combined across YTC and Camp Guernsey were significantly $(\mathrm{P}<0.05)$ greater in Vavilov II (53 $\left.\mathrm{g} \mathrm{plot}^{-1}\right)$ than Vavilov (39 $\left.\mathrm{g} \mathrm{plot}^{-1}\right)($ Table 67 in Appendix D.9). 


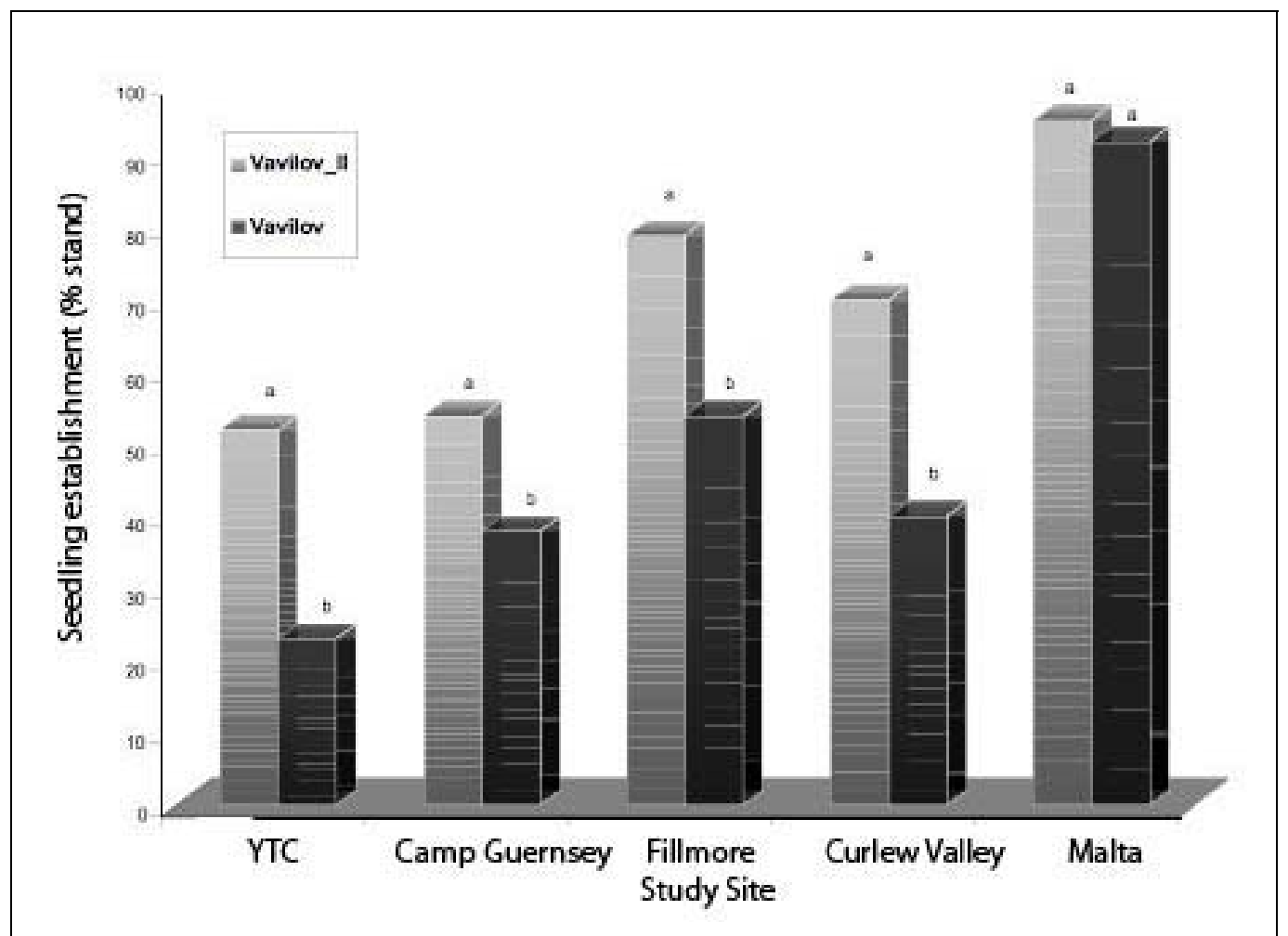

Figure 18. Seedling establishment for Vavilov II Siberian wheatgrass at five sites (Jensen et al. 2009).

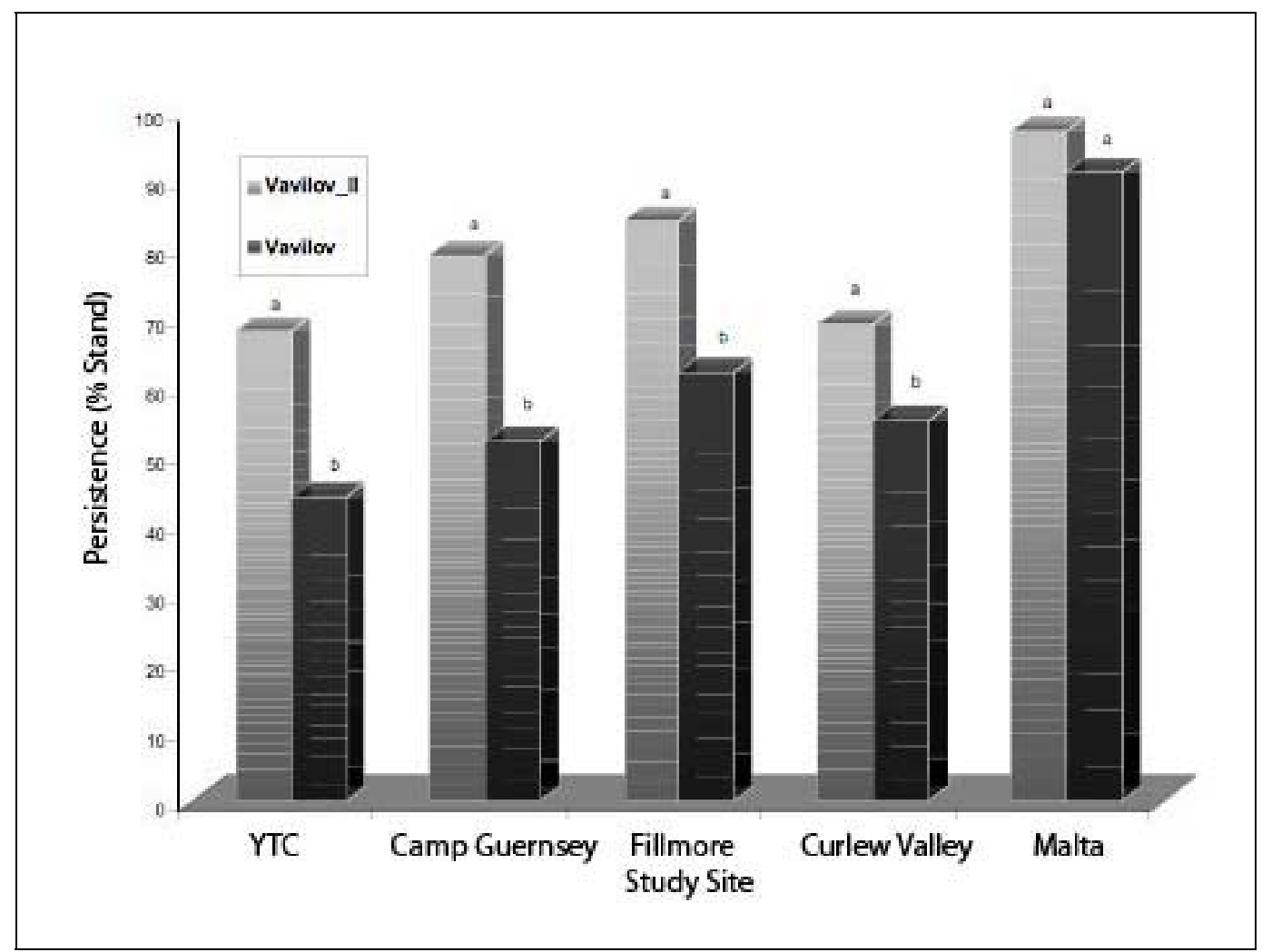

Figure 19. Persistence for Vavilov II Siberian wheatgrass at five sites (Jensen et al. 2009). 
Bozoisky II Russian wildrye was selected for improved seed germination and seedling vigor. Bozoisky-II was evaluated in the Northern Plains Area (NPA) Regional Trials established in 1999 for initial stand, persistence, and dry matter forage production. Initial stands and persistence of Bozoisky-II were similar to Bozoisky-Select and Mankota combined over and within locations (Tables 68-70 in Appendix Section D.9). However, Bozoisky-II established significantly better and yielded greater than the tetraploid cultivar Tetracan and the tetraploid germplasm Tetra-1 (Jensen et al. 1998). Dry matter yields of Bozoisky-II, BozoiskySelect, and Mankota were similar except at Green Canyon, UT, where Bozoisky-II had significantly greater $(\mathrm{P}<0.05)$ yield than Mankota (Table 71 in Appendix D.9). 


\section{Performance Assessment}

The sections below discuss each performance objective previously shown in Table 4.

\subsection{Improved establishment of modified germplasms}

This objective was met for our four new cultivars. In field-spaced nursery trials, the cultivars Bozoisky-II Russian wildrye, FirstStrike slender wheatgrass, Recovery western wheatgrass, and Vavilov II Siberian wheatgrass had significantly $(\mathrm{P}<0.05)$ greater stand establishment than base population cultivar after one or more years as detailed below.

Recovery western wheatgrass was selected for seedling vigor and quick establishment under rangeland conditions. It was evaluated extensively at semiarid sites representative of different ecological regions in northern plains and western United States. Overall, it has shown superior and faster seedling establishment compared to commercially available cultivars Arriba, Barton, Flintlock, Rodan, and Rosana (Waldron et al. in press). Across locations, Recovery had higher frequency $(\mathrm{P} \leq 0.05)$ of plants than any other western wheatgrass cultivar until the fourth to sixth year after planting (see Figure 17). The rapid establishment of Recovery, in comparison to other western wheatgrass cultivars, will allow land managers to use this native grass species to help limit weed infestation and soil erosion in areas where the regularity of disturbances normally prevents western wheatgrass from becoming fully established (Waldron et al. in press).

Bozoisky-II Russian wildrye had significantly ( $\mathrm{P} \leq \mathrm{0.05})$ more seedlings per unit area than two other Russian wildrye germplasms in the study (Jensen et al. 2006) (see Tables 68-69 in Appendix Section D.9). Selection emphasis on Bozoisky-II was for increased seedling vigor during establishment.

During the establishment year, Vavilov II Siberian wheatgrass had significantly $(\mathrm{P}<0.05)$ higher numbers of seedlings per unit area at five locations (Tables 63-66 in Appendix Section D.9). 
FirstStrike slender wheatgrass was selected for persistence and overall plant vigor in response to drought. Although selection emphasis was not on seedling establishment, it appears than an increase in seedling vigor was correlated with the selection for persistence and plant vigor under extremely dry conditions in this population. In seeded trials at four sites, FirstStrike had significantly $(\mathrm{P}<0.05)$ more seedlings per unit area $\left(\mathrm{m}^{2}\right)$ than did the cultivar Pryor slender wheatgrass in the establishment year (Tables 13, 29, 30). FirstStrike germinated five days earlier than Pryor on three different soil types (sandy loam, loam, and sandy) (Jensen et al. 2007) and at all but one temperature in growth pouch studies (Table 26).

\subsection{Release of new germplasms}

We met this objective by releasing six germplasms under the ESTCP program with a seventh currently in preparation. Four of those releases are cultivars and are discussed in the next section. Reliable Sandberg bluegrass and Yakima western yarrow were released as pre-variety germplasms (see Appendix $\mathrm{C}$ for a discussion of release types).

Yakima western yarrow was released as a source-identified class germplasm (Waldron et al. 2006b). The diversity within this germplasm is evident in the range of phenotypic differences found in the Generation G1 field. The field of G1 generation Yakima western yarrow showed excellent, vigorous growth in the nursery site at Cache County, Utah. Yakima was successfully established in a field trial at YTC, and an earlier western yarrow collection (1994) from the same 26 locations was tested at YTC, where it established and persisted much better than common variety-notstated western yarrow. Yakima western yarrow is intended for use in rehabilitation and restoration of western rangelands. It should be particularly useful to help stabilize and add diversity to severely disturbed sites, such as military training lands and lands post wildfires.

Reliable Sandberg bluegrass was released as a selected-class germplasm (Waldron et al. 2006a). It was successfully established in several trials in Utah and Idaho and at YTC. Sandberg bluegrass is an important understory grass in the bluebunch wheatgrass-sagebrush ecological sites of the Intermountain and Northwest regions of the United States. It is a medium-lived, perennial bunchgrass valuable for soil erosion control, spring livestock and wildlife grazing, and biodiversity. It resists trampling and often is one of the first species to reestablish on sites disturbed by fire, large equipment and vehicles, and animals. Reliable's 
intended use is for rehabilitation and restoration of western rangelands. It may be particularly useful as a pioneer plant species on severely disturbed sites, such as military training sites and after wildfires.

\subsection{Release of new cultivars}

We exceeded our goal of releasing two or more germplasms as cultivars under the ESTCP program. Four SERDP-select plant germplasms were released as cultivars with the potential for Plant Variety Protection (PVP) based on their breeding history and their response to selection for seedling vigor, persistence, and ability to regrow after disturbance. A minimum level of significance was set at alpha $=0.05$, and SERDP-select materials were tested against these criteria. A fifth cultivar release of Snake River wheatgrass is possible in the next couple of years.

'Bozoisky-II' Russian wildrye was released in 2005 (Jensen et al. 2006). Bozoisky-II was selected for seedling vigor (emergence from a deep planting depth), seed mass, seed yield, vegetative vigor, total dry matter production, and response to drought. Bozoisky-II has a much broader genetic base than other Russian wildrye cultivars and has been evaluated extensively on rangeland sites in western United States. Seedling establishment of Bozoisky-II has been equal to or greater than commercially available cultivars. Within the Great Basin and Northern Great Plains, Bozoisky-II is adapted to sage-brush, mountain-brush, and pinyon-juniper on arid to semiarid rangelands. It is best adapted to loam and clay soils, although acceptable stands can be obtained on a wide range of soil types. Russian wildrye's resistance to drought exceeds that of crested wheatgrass (Asay and Jensen 1996).

'FirstStrike' slender wheatgrass was released in 2006 (Jensen et al. 2007). FirstStrike was selected for persistence and overall plant vigor in response to drought. FirstStrike is a multi-origin composite of four collections from Colorado and Wyoming and has been evaluated extensively on rangeland sites in western United States with seedling establishment equal to or better than commercially available cultivars.

'Vavilov II' Siberian wheatgrass was released in 2008 (Jensen et al. 2009). Vavilov II was developed for reseeding sandy soils on disturbed rangelands dominated by annual weeds as a result of severe disturbance, frequent fires, and soil erosion. Selection emphasis was on seedling establishment and plant persistence. The development of Vavilov II gives 
land managers new plant materials with enhanced seedling establishment and persistence on dry harsh rangelands.

'Recovery' western wheatgrass was released in 2009 (Waldron et al. in press). Recovery was developed for reseeding rangelands following severe disturbance, frequent fires, and soil erosion. Selection emphasis in Recovery was on improved and faster seedling establishment. During the establishment year, Recovery had increased frequency of seedlings when averaged across eight locations than 'Arriba', 'Barton', 'Flintlock', 'Rodan', and 'Rosana' western wheatgrasses. Recovery continued to have superior stand until 4 to 6 years after planting, when due to their rhizomatous nature, all the western wheatgrasses were equal. Recovery is especially intended for revegetation of frequently disturbed rangelands, military training lands, and areas with repeated wildfires.

\subsection{Improved resilience of modified germplasms to military traffic}

Three of the SERDP-modified entries-Bozoisky II Russian wildrye, Vavilov II Siberian wheatgrass, and SERDP-select Snake River wheatgrass-did significantly $(\mathrm{P}<0.05)$ better than the commonly available varieties for all treatments. All entries, except for Pryor slender wheatgrass, had significantly less cover at the 4-pass treatment as compared to the 1-pass treatment. A large jump in soil moisture 1 year after tracking resulted in a higher overall plant cover, making it harder to discern what was happening as a result of the tracking.

\subsection{Improved establishment of native grass stands}

We studied the improved establishment rates of native plants using various mixed seedings at three locations (YTC, Camp Guernsey, Fort Drum). At all three locations in two climatic areas, we obtained native plant stands by combining native and introduced species together. Although there were few significant differences among the mixes, all of our mixes established significantly better $(\mathrm{P}<0.05)$ than the standard Guernsey mix at the Guernsey River site. At the Guernsey Tower site after 1 year, all mixes had significantly greater cover than the Guernsey mix, and the introduced-native mix 1 had significantly greater stand than the native only mix 2 . At Fort Drum, we were able to obtain a stand of switchgrasses in 4 years. 


\subsection{Reduction of noxious weeds on training lands}

Although we found no significant differences at YTC or Guernsey, the highest percentage of weeds were found with the all-native mix 2 and core native mix 4 at the Guernsey River site after 2 years. At Fort Drum, we did not test an all-native mix, but weed percentages were very low in all introduced-native mixes except the weeping lovegrass-hairgrass mixture after 4 years; the native hairgrass was not successful in any mixture and the weeping lovegrass had died back after 4 years allowing undesired species to move in.

In earlier work at Fort Carson, which we used for our cost assessment analysis, we also showed reduction in weed stands across all our mixtures after 3 years (see Figure 3).

\subsection{Qualitative results}

\subsubsection{Reliability}

We have shown the reliability of the modified germplasms with successful plantings at four facilities in two climatic areas. Across all studies, the germplasms were able to establish and grow within the 4-year time frame of this demonstration. The germplasms were able to survive under various settings including military vehicle tracking and different climatic regimes.

\subsubsection{Ease of use}

All seedings were completed with conventional no-till seeding equipment, which is a one-pass procedure in wide use at military facilities. The modified germplasms and ecological-bridge mixtures require no additional equipment, labor, or skills.

\subsubsection{Versatility}

As noted above, we have demonstrated successful and improved performance in a variety of locations under different conditions.

\subsubsection{Maintenance}

No maintenance is required. 


\subsubsection{Availability of seed}

Because there is no significant increase in cost to use our modified plants or seeding methods, the only barrier to implementation of the technology would be the cost and availability of seeds of the modified varieties. One of our goals was to convince producers to grow the seed in large enough quantities to make their prices comparable to those already on the market.

We entered into a contract with the USDA Natural Resources Conservation Service (USDA-NRCS) Plant Material Center in Aberdeen, Idaho, to produce seed of new SERDP select germplasms of three species. About 5,200 pounds of seed were produced for distribution to military facilities in $\mathrm{FYO}$, and a comparable amount of seed was produced in FYo8. The seed was distributed to YTC, Mountain Home Air Force Base (Idaho), Fort Carson, Camp Williams (Utah), Camp Guernsey, and Fort Riley (Kansas). Our first sale of seed to a commercial producer was completed in 2007. The producers purchased $300 \mathrm{lb}$ of FirstStrike slender wheatgrass foundation seed that will result in $36,000 \mathrm{lb}$ of seed for sale at a value of $\$ 270,000$.

The seeds for many of these germplasms should be available for some time; additional growers are producing seeds for retail sale, and the USDA-NRCS is recommending some of these germplasms for seeding to restore lands.

\subsubsection{Awareness of seed capabilities and planting methods}

To help market the new germplasms, we prepared two white papers describing the release of the new germplasms and their potential vulnerability and resistance to invasive species: "Decision Paper on Public Releases for the Germplasms Developed under the SERDP and ESTCP Programs" (see Appendix B) and "Implementation and Commercialization of New Germplasms for Use on Military Ranges."

The demonstration studies conducted during this program were made available for inspection by land managers in the Intermountain West and Northeast United States climatic regions. We also gave presentations about our modified germplasms and ecological-bridge mixtures at several military facilities and at professional and military-related meetings. 
We partnered with the Army Environmental Command (AEC) to prepare a planting guide for selecting appropriate ecological-bridge seed mixtures (Palazzo et al. 2009). We are currently expanding our geographic area by promoting the ecological-bridge concept to military bases in Hawaii and the Southeastern United States. 


\section{Cost Assessment}

This cost assessment is based primarily on work performed earlier at Fort Carson. Those results are summarized in Section 2.2.

\subsection{Cost model}

The Environmental Cost Analysis Methodology (ECAM) tool is designed to facilitate the gathering and analyzing of economic data in a manner that will allow for more accurate evaluation of investment in pollution prevention technologies. Our project did not involve hazardous waste materials, and, as such, we do not meet the criteria for environmental reporting requirements and we did not use the ECAM tool.

In our project, we used equipment that is similar to or the same as equipment that is already in place at the facilities in the project's application. In this case, the cost difference is minimal in the proposed process as compared to the one currently used at the sites. The only minor increased cost we can envision may be in the increased cost to purchase the new seeds initially. With greater demand, the cost of the seeds should decrease and be comparable to those currently on the market, which should ultimately lead to reduced overall costs. Table 31 summarizes the costs related to revegetation with our modified germplasms and ecological-bridge mixtures. Section 7.3 includes information on costs related to current revegetation practices.

Table 31. Cost model for seeding modified germplasms or ecological-bridge mixtures.

\begin{tabular}{|lll|}
\hline Cost element & $\begin{array}{l}\text { Data tracked during the } \\
\text { demonstration }\end{array}$ & Estimated costs \\
\hline Seed costs & $\begin{array}{l}\text { Modified germplasms, new } \\
\text { cultivars }\end{array}$ & $\begin{array}{l}\text { Possible increase in seed costs for } \\
\text { new germplasms and cultivars }\end{array}$ \\
Installation costs & $\begin{array}{l}\text { Labor, equipment, and chemicals } \\
\text { needed to seed }\end{array}$ & No change from normal operations \\
Operation costs & None necessary & None \\
Monitoring costs & None necessary & None \\
Maintenance & Reseeding requirements & No or reduced need to reseed \\
\hline
\end{tabular}




\subsection{Cost drivers}

No new equipment, skills, health and safety requirements, or regulatory standards are needed to use the new germplasms or seeding methods. Existing equipment and no-till seeding methods can be employed to seed the new varieties and mixtures. The key to "implementation" of this methodology is the proper decision making for selecting appropriate revegetation materials. We prepared a planting guide (Palazzo et al. 2009) that includes detailed information on plant selection for specific microclimatic ranges, training scenarios, and locations for optimal uses for each improved germplasm, as well as guidelines for selecting appropriate ecological bridge seed mixes.

The factors affecting cost and performance are the availability and cost of the improved germplasms and cultivars, and the cost savings resulting from improved performance of the vegetation. Currently available planting equipment and skills are used with the new materials. The only differences are which types of seeds or mixtures of seeds are planted. The seeds for the new plant materials are unlikely to differ greatly in cost from currently used cultivars.

Potential cost savings can be realized from (a) the ability to seed less frequently because of increased establishment rates and better wear resiliency, (b) a decrease in the need to consider other methods of controlling invasive weeds, and (c) the reduced downtime on ranges which should lead to cost efficiencies in scheduling training programs.

Using native plant species over introduced plant species can increase seed costs significantly because the native species are not as widely used.

However, the actual land preparation and seeding practices should remain the same with our modified germplasms and recommended mixtures, and the frequency should be reduced for reseeding operations and the amount of chemical or mechanical control of noxious weeds.

\subsection{Cost analysis and comparison}

We provided a cost estimate for one example of cost savings at Fort Carson that considers the greater resilience of the new germplasms and the faster establishment rates of native plants using the ecological-bridge mixtures (Table 32). However, it is difficult to obtain a cost comparison since our results provide choices to military land managers who have an array of 
considerations in obtaining a vegetative cover on military lands. Those considerations include the intensity of land use, the choice of native or introduced plants, and the degree of encroachment by noxious weeds. Each consideration requires different seed selections, as described in our planting guide (Palazzo et al. 2009).

We conducted one of our early tests on ecological-bridge seed mixtures at Fort Carson, comparing several test mixtures with the standard Fort Carson mix (Palazzo et al. 2003; see also Section 2.2 of this report). At the same time, we looked into current seeding practices on that facility because it is a good candidate for using the new germplasms and seed mixtures.

Land rehabilitation at Fort Carson currently involves an average of 4,000 acres annually, for an annual cost of $\$ 260,000$ (based on $\$ 65$ per acre cost). The time required between reseedings is based on land use. Intensely used areas need to be seeded annually, and those with little or no use will probably never need reseeding. Moderately used lands are generally reseeded every $3-5$ years, with an average of every 4 years. We believe that using our modified germplasms and new cultivars in the mixtures can conservatively extend the use of moderately used areas by at least 2 years; in other words, such areas would generally require reseeding every 6 years. The tables below show some calculations for cost savings based on the frequency of seeding those moderately used land areas.

Table 32 shows the average annual cost of seeding an acre of moderately used lands assuming a 4-year cycle for existing germplasms and a 6-year cycle for SERDP-modified germplasms. Depending on seed cost, there will be a savings of $28 \%-33 \%$. 
Table 32. Approximate costs of seeding moderately used lands at Fort Carson.

\begin{tabular}{|c|c|c|c|}
\hline & $\begin{array}{l}\text { Existing } \\
\text { germplasms }\end{array}$ & $\begin{array}{c}\text { New } \\
\text { germplasms at } \\
\text { same seed cost }\end{array}$ & $\begin{array}{c}\text { New germplasms } \\
\text { with } 20 \% \text { increase in } \\
\text { seed cost }\end{array}$ \\
\hline Seeding cost per acre & $\$ 65$ & $\$ 65$ & $\$ 70$ \\
\hline $\begin{array}{l}\text { Average time between } \\
\text { reseedings }\end{array}$ & 4 years & 6 years & 6 years \\
\hline $\begin{array}{l}\text { Average annual seeding cost per } \\
\text { acre of moderately used land } \\
\text { (cost per acre / years between } \\
\text { seedings) }\end{array}$ & $\$ 16.25$ & $\$ 10.83$ & $\$ 11.67$ \\
\hline $\begin{array}{l}\text { Average annual seeding savings } \\
\text { per acre of moderately used land }\end{array}$ & - & $\$ 5.42$ & $\$ 4.58$ \\
\hline Annual savings & & $33 \%$ & $28 \%$ \\
\hline
\end{tabular}

Although the number of moderately used acres to be sown changes annually, it usually is about 2,000 acres at Fort Carson, accounting for about half of the estimated $\$ 260,000$ annual cost of land rehabilitation, or $\$ 130,000$ per year. If we multiply that annual seeding cost $(\$ 130,000$ per year) by the percent of annual savings (33\% or $28 \%$ ) as shown above, we produce a net savings of $\$ 42,900$ or $\$ 36,400$ per year. 


\section{Implementation Issues}

The end-users for the modified plant germplasms and seeding methods are land managers on military and other federal lands. They need to know that our seeds and planting methods will produce improved, lowmaintenance results on their lands, and sufficient seeds must be available to them at a cost equal to or less than currently available plant materials. The seeds themselves may be used over a wide geographic area (see Figure 6); the only "customization" required is selection of appropriate species for use at individual facilities in terms of soil type, land use, climate, and types of plants desired (native and/or introduced species).

The demonstrations described in this report should provide land managers with ample justification to use our new plant materials and suggested mixtures. Throughout the project, our demonstration plots at two military installations have been open to land managers to increase awareness and promote transfer of the technology. We have consulted, and will continue to consult, with military land managers at numerous sites by phone and in person. We have presented our findings at conferences, workshops, and other appropriate forums, such as ITAM meetings (Palazzo et al. 2006, 2007) and the Battelle Conference on Sustainable Range Management in New Orleans (January 2004). As appropriate or when requested, we will distribute copies of the official germplasm release notices along with our existing reports on our spring 2002 workshop on the modified germplasms (Hardy and Palazzo 2002), our final SERDP report (Palazzo et al. 2003), this report, and the Planting Guide (Palazzo et al. 2009).

The Planting Guide (ibid.) that we produced as part of this demonstration project provides the necessary information on the use of the modified germplasms with other compatible species in seeding mixtures, planting recommendations, and criteria to select appropriate ecological-bridge methods. The planting guide includes sections on land use in the western United States, along with detailed information on individual species. Each land use intensity and eco-region section gives suggestions for appropriate species and mixes for various training-land uses and vegetation goals. Users may then refer to the detailed species section for information on planting. 
We decided to go through a public release of the seed as opposed to a private release. The advantages to a public release are that foundation seed used to produce seed commercially will be available to all growers, and the greater distribution should lower the cost of the seed. The disadvantage to the public release is that poor quality seed may be produced and hurt the reputation of the new germplasm. Also, since many growers have the new germplasm, some may be a reluctant to market the seed. We hope to overcome this by working with seed producers.

We made seed available to military land managers for demonstration purposes. Initially, we contracted with the USDA-NRCS Plant Material Center in Aberdeen, Idaho, to produce sufficient seed for selected military facilities at no cost; seed was distributed in FYo7 and FYo8. As the germplasms continue to prove themselves and the demand for the seed becomes known, we anticipate that commercial seed producers will be more interested in carrying the seeds for sale. Also, to support the use of our new germplasms, the USDA-NRCS has acknowledged the improved performance of our species by including several our germplasms on their recommended list that retail seed buyers use to select cultivars of various grass species. At this time, only SERDP FirstStrike Slender wheatgrass is available for commercial sale, and it was recently included in a Fort Carlson seed purchase of $\$ 30,000$.

Other military involvement related to this program:

- The results of the ecological-bridge research have been used for the last 8 years at Fort Drum to more effectively establish native plants on sandy soils. Our tests showed that the seed mixture allowed the military to use the land again in less time. In 2009, we held a meeting at Fort Drum to demonstrate this concept. Invited participants included people from Camp Ripley, Minnesota; Fort Bragg, North Carolina; Fort Indiantown Gap, Pennsylvania, and the AEC.

- Yakima Training Center has been using the seeding recommendations provided for the past 2-3 years with good results, and their plan is to include other recommendations as they become available. Their direct claim is:

One of the most important aspects that has helped us has been the work you have done with improvement 
of the native species. In fact, we have developed some aggressive erosion control projects (stream bank sloping projects similar to what Jeff has done at Carson) for implementation this spring and summer that includes use of some of these native species for revegetation efforts. Having these species become available was a major factor in our decision to carry out this aggressive bank sloping effort because we knew revegetation would actually be the key to overall success. Without these species, the project would be dead on arrival at Yakima.

- Yakima Training Center is also using our methods to reseed upland areas following disturbance. Both the Record of Decisions (RODs) for the YTC Expansion and the Fort Lewis Stationing actions include requirements for continued upland reseeding of up to 4,000 acres annually to mitigate impacts associated with erosion, surface water quality, and noxious weeds. These mitigation requirements are direct benefactors of this ongoing research effort to develop the various cultivars.

- Recently we have expanded the ecological bridge concept to military facilities in the Southeastern United States and Hawaii. 


\section{References}

Affleck, R.T., S. Shoop, K. Simmons, and P. Ayers. 2004. Vehicle rutting during spring thaw. In Proceedings ASCE Cold Regions Engineering Specialty Conference, held May 2004 in Edmonton, Canada.

AOSCA. 2003. The AOSCA native plant connection. Meridian, Idaho: Association of Official Seed Certifying Agencies.

Asay, K.H., and K.B. Jensen. 1996. The wildrye grasses. In Cool-season forage grasses. eds. L.E. Moser, , D.R. Buxton, and M.D. Casler. Agronomy Monograph Series 34:725-748.

, N.J. Chatterton, K.B. Jensen, R.R.-C. Wang, D.A. Johnson, W.H. Horton, A.J. Palazzo, and S.A. Young. 1997. Registration of 'CD-II' crested wheatgrass. Crop Science 37: 1023.

, K.B. Jensen, W.H. Horton, D.A. Johnson, N.J. Chatterton, and S.A. Young. 1999. Registration of 'RoadCrest' crested wheatgrass. Crop Science 39: 1535.

, W.H. Horton, K.B. Jensen, and A.J. Palazzo. 2001. Merits of native and introduced Triticeae grasses on semiarid rangelands. Canadian J ournal of Plant Sciences 81: 45-52.

Bailey, R.G. 1995. Description of the ecoregions of the United States, 2 d ed. Miscellaneous Publication 1391.Washington, D.C.: USDA-Forest Service.

Barker, R. E., R. E. Ries, and P.E. Nyren. 1977. Forage species establishment and productivity on mined land. Res. 34:8-12. North Dakota Agr. Exp. Sta. Farm

Cary, T.J., A.J. Palazzo, and K.H. Asay. 2001. Innovative techniques to establish native plants. Presented at the Tenth Annual ITAM Workshop on Military Land Rehabilitation and Management in Nashville, TN.

Daubenmire, R. 1970. Steppe vegetation of Washington. Technical Bulletin 62. Pullman, Washington: Washington Agricultural Experiment Station, College of Agriculture, Washington State University.

Hardy, S.E., and A.J. Palazzo. 2002. Report on the workshop on new grass germplasms and invasive weed control. ERDC/CRREL SR-02-2. U.S. Army Engineer Research and Development Center, Cold Regions Research and Engineering Laboratory, Hanover, NH. Available at (accessed June 2009): http://libweb.wes.army.mil/uhtbin/hyperion/CRREL-SR-02-2.pdf

Hu, Z.-M., R.R.-C. Wang, S. Larson, A.J. Palazzo, K.H. Asay, and N.J. Chatterton. 2000. Studies on quantitative traits of Hycrest growing at low temperatures using AFLP and RAPD markers. Presented at Plant and Animal Genome VIII Conference, San Diego, CA. 
, R.R.-C. Wang, S. Larson, A.J. Palazzo, K.H. Asay, and N.J. Chatterton. 2001. Selection response for molecular markers associated with anthocyanin coloration and low-temperature growth traits in crested wheatgrasses. Canadian J ournal of Plant Sciences 81: 665-671.

X.L. Wu, S.R. Larson, R.R.C. Wang, T.A. Jones, N.J. Chatterton, and A.J. Palazzo. 2005. Detection of linkage disequilibrium QTLs controlling lowtemperature growth and metabolite accumulations in an admixed breeding population of Leymus wildryes. Euphytica 141:263-280.

Jensen, K.B., K.H. Asay, D.A. Johnson, W.H. Horton, A.J. Palazzo, and N.J. Chatterton. 1998. Registration of RWR-Tetra-1 Tetraploid wildrye germplasm. Crop Science 38: 1405 .

, K.H. Asay, D.A. Johnson, and B.J. Li. 200o. Characterization of Siberian wheatgrass germplasm (Agropyron fragile) from Kazakhstan, U.S.S.R. (Poaceae: Triticeae). J ournal of Range Management 53: 347-352.

, K.H. Asay, D.A. Johnson, S.R. Larson, B.L. Waldron, and A.J. Palazzo. 2006. Registration of 'Bozoisky-II' Russian wildrye. Crop Science 46: 986-987.

, A.J. Palazzo, B.L. Waldron, and B.S. Bushman. 2007. Registration of 'FirstStrike' slender wheatgrass. J ournal of Plant Registrations 1: 24-25.

A.J. Palazzo, B.L. Waldron, J.G. Robins, B.S. Bushman, D.A. Johnson, and D.G. Ogle. 2009. 'Vavilov II', a new Siberian wheatgrass cultivar with improved persistence and establishment on rangelands. J ournal of Plant Registrations 3: 61-64.

Jones, D.S., and C.F. Bagley. 1997. Tracked military vehicle impacts on three vegetation communities at Yakima Training Center, Washington: Results for the 19941996 study period. TPS 97-4. Fort Collins, CO: Center for Ecological Management of Military Lands, Colorado State University.

Jones, T.A., S.R. Larson, D.C. Nielson, S.A. Young, N.J. Chatterton, and A.J. Palazzo. 2002. Registration of P-7 bluebunch wheatgrass germplasm. Crop Science 42: $1754-1755$.

Keystone Center. 1996. Keystone Center policy dialogue on Department of Defense (DoD) biodiversity management strategy (1993-1996). Report \#54. Keystone, Colorado: The Keystone Center. Ordering information at http://www.keystone.org/spp/environment/natural-resources (accessed Oct 2009).

Kilcher, M. R. and Looman, J. 1983. Comparative performance of some native and introduced grasses in southern Saskatchewan. J ournal of. Range Management $36: 654-657$.

Larson, S.R., T.A. Jones, Z.M. Hu, R.R. Wang, P.A. Harrison, D.C. Nielson, A.J. Palazzo, and N.J. Chatterton. 1999. QTL studies of low-temperature growth in Leymus wildryes. Salt Lake City, Utah: American Society of Agronomy Abstracts p. 155.

, T.A. Jones, Z.-M. Hu, A.J. Palazzo, and C.L. McCracken. 200o. Genetic diversity of bluebunch wheatgrass cultivars and a multiple-origin polycross. Crop Science 40: 1142-1147. 
B.L. Waldron, S. Monsen, L. St. John, A.J. Palazzo, C.L. McCracken, R.D. Harrison. 2001. Patterns AFLP variation in the Poa bluegrasses of western North America. Crop Science 41: 1300-1305.

, A.J. Palazzo, and K.B. Jensen. 2003. Identification of western wheatgrass cultivars and accessions by DNA fingerprinting and geographic provenance. Crop Science 43: 394-401.

, X. Wu, T.A. Jones, K.B. Jensen, N.J. Chatterton, B.L. Waldron, J.G. Robins, B.S. Bushman, and A.J. Palazzo. 2006. Comparative mapping of growth habit, plant height, and flowering QTLs in two interspecific families of Leymus. Crop Science 46: 2526-2539.

Lawrence, T., and C. D. Ratzlaff. 1989. Performance of some native and introduced grasses in a semiarid region of western Canada. Canadian J ournal of Plant Science 69: 251-254.

Liu, X.L., R.R.C. Wang, K.B. Jensen, A.J. Palazzo, N.J. Chatterton, and K.H. Asay. 1997. RAPD and STS markers for fast-germinating western wheatgrass and salina wildrye. Paper at ASA 1997 meeting held October 26-31, 1997 in Anaheim, CA.

Loffredo, E., A.J. Palazzo, N. Senesi, and C.E. Clapp. 2007. Effects of humic acids on germination and early growth of three native American plants under controlled conditions. Paper from Structure, Properties and Uses section of International Conference on Humic Science and Technology Ten, held March 21-23, 2007 at Boston, MA. (See abstracts, p. 51).

Palazzo, A.J., P. Zang, and T. Cary. 1996. Improved rehabilitation of sandy soils in cold regions. Presented at the Integrated Training Area Management (ITAM) Workshop, Fort McCoy, WI, August 1996. Published by College of Natural Resources, University of Wisconsin, Stevens Point, WI, p. 85-97.

S.E. Hardy, and K. Taylor. 1999. Report of independent review panel meeting: Evaluation of naturalized species being used for new cultivar development. CRREL Contract Report CON 154, U.S. Army Cold Regions Research and Engineering Laboratory, Hanover, $\mathrm{NH}$.

, T.J. Cary, and K.H. Asay. 2001. Planting techniques to establish native plant meadows. Tri-Services DoD Pest Management Workshop, Jacksonville, FL.

, T.J. Cary, and S.E. Hardy. 2002. Native plant germplasms and native plant establishment. In Proceedings of Invasive Plants and Restoration in the West: A Partnership Workshop, Dec. 9-11, 2002, Salt Lake City Utah, p. 13.

, S. E. Hardy, and K.B. Jensen. 2003. Improved native grasses and establishment methods for use on military training lands. ERDC/CRREL TR03-20. Hanover, NH: U.S. Army Engineer Research and Development Center, Cold Regions Research and Engineering Laboratory. Available at (accessed June 2009): http://libweb.wes.army.mil/uhtbin/hyperion/CRREL-TR-03-20.pdf

, K.B. Jensen, B.L. Waldron, and T.J. Cary. 2005. Effects of tank tracking on range grasses. J ournal of Terramechanics 42: 177-191. 
, T. Cary, T. Lent, I. Warden and D. Huff. 2006. Rehabilitating sandy soil military lands with native plants. Presented at Fifth Eastern Native Grass Symposium, held 10-13 October, 2006 in Harrisburg, PA, p. 269.

, T. Cary, T. Lent, I. Warden, and D. Huff. 2007. Rehabilitating sandy soil military lands with native plants. National Military Fish and Wildlife Association meeting, 19-22 March, 2007, Portland, OR.

, S.E. Hardy, T.J. Cary, K.H. Asay, K.B. Jensen, and D.G. Ogle. 2009. Intermountain West military training lands planting guide: selecting seed mixtures for actively used military lands. ERDC/CRREL TR-09-9. Hanover, NH: U.S. Army Engineer Research and Development Center, Cold Regions Research and Engineering Laboratory. Available at (accessed June 2009): http://libweb.wes.army.mil/uhtbin/hyperion/CRREL-TR-03-20.pdf

Rogers, L.E. and W.H. Rickard. 1998. Introduction: Shrub steppe lands. Pages 1-12. In: L.E. Rogers, W.H. Rickard, B.E. Vaughn, and S.F. Liebetrau (ed.). Shrub steppe: Balance and change in a semi-arid terrestrial ecosystem. Elsevier. Amsterdam.

SAS Institute Inc. 1999. SAS/ STAT User's guide, ver. 6, fourth edition. Cary, North Carolina: SAS Institute, Inc.

U.S. Army at Fort Drum. 2001. Integrated natural resources management plan 20012005. Fort Drum, NY: Natural Cultural Resources Branch, Environmental Division, Public Works.

U.S. Army at Dugway Proving Grounds. 2005. Integrated natural resources management plan 2005-2010. Dugway Proving Grounds, UT: Natural Cultural Resources Branch, Environmental Division, Public Works.

Vallentine, J. F. (ed.) 1977. U. S. - Canadian range management, 1935-1977: A selected bibliography on ranges, pastures, wildlife, livestock, and ranching, pp. 130-134. Phoenix, AZ: Oryx Press.

Vogel, K.P., and R.A. Masters. 2001. Frequency grid-A simple tool for measuring grassland establishment. J ournal of Range Management 54:653-655.

Waldron, B.L., T.A. Monaco, K.B. Jensen, R.D. Harrison, A.J. Palazzo, and J.D. Kulbeth. 2005. Coexistence of native and introduced perennial grasses following simultaneous seeding. Agronomy J ournal 97: 990-996.

, S.R. Larson, K.B. Jensen, R.D. Harrison, A.J. Palazzo, and T.J. Cary. 2006a. Registration of Reliable Sandberg Bluegrass germplasm. Crop Science 46: 487488.

, S.R. Larson, K.B. Jensen, R.D. Harrison, A.J. Palazzo, and T.J. Cary. 2006b. Registration of Yakima Western Yarrow germplasm. Crop Science 46: 488-489.

, K.B. Jensen, A.J. Palazzo, T.J. Cary, J.G. Robins, M.D. Peel, D.G. Ogle, and L. St. John (in press) 'Recovery', a new western wheatgrass cultivar with improved seedling establishment on rangelands. J ournal of Plant Registrations. 
Warren, S.D., G.M. Senseman, P.R. Block, T.S. Ruzycki, and D.D. Wilcox. 200o. Soil erosion survey for Camp Guernsey, Wyoming using new-generation multidimensional soil erosion modeling. Contract report submitted to Wyoming National Guard, Cheyenne, WY. 


\section{Appendix A: Points of Contact}

\begin{tabular}{|c|c|c|c|}
\hline $\begin{array}{l}\text { Point of } \\
\text { Contact }\end{array}$ & Organization & Phone / Fax / email & Role in Project \\
\hline $\begin{array}{l}\text { Antonio J. } \\
\text { Palazzo }\end{array}$ & $\begin{array}{l}\text { ERDC-CRREL } \\
72 \text { Lyme Road } \\
\text { Hanover, NH 03755-1290 }\end{array}$ & $\begin{array}{l}\text { 603-646-4374 } \\
\text { Fax: 603-646-4785 } \\
\text { Antonio.J.Palazzo@usace.army.mil }\end{array}$ & $\begin{array}{l}\text { Lead PI, project } \\
\text { implementation } \\
\text { and coordination, } \\
\text { establishment } \\
\text { studies, cultivar } \\
\text { releases }\end{array}$ \\
\hline Timothy J. Cary & $\begin{array}{l}\text { ERDC-CRREL } \\
72 \text { Lyme Road } \\
\text { Hanover, NH 03755-1290 }\end{array}$ & $\begin{array}{l}\text { 603-646-4358 } \\
\text { Fax: 603-646-4785 } \\
\text { Timothy.J.Cary@usace.army.mil }\end{array}$ & $\begin{array}{l}\text { Establishment } \\
\text { studies, plot } \\
\text { monitoring }\end{array}$ \\
\hline $\begin{array}{l}\text { Kevin B. } \\
\text { Jensen }\end{array}$ & $\begin{array}{l}\text { USDA-ARS Forage and Range } \\
\text { Research Lab } \\
695 \text { North } 1100 \text { East } \\
\text { Utah State University } \\
\text { Logan, UT } 84322-6300\end{array}$ & $\begin{array}{l}\text { 435-797-3099 } \\
\text { Fax: 435-797-3075 } \\
\text { kevin.jensen@ars.usda.gov }\end{array}$ & $\begin{array}{l}\text { Plant-breeding, } \\
\text { establishment } \\
\text { studies, cultivar } \\
\text { releases }\end{array}$ \\
\hline Dick Gebhart & $\begin{array}{l}\text { ERDC-CERL } \\
\text { 2902 Newmark Drive } \\
\text { Champaign IL 61822-1076 }\end{array}$ & \begin{tabular}{|l|} 
217-352-6511, x5847 \\
Fax: 217-373-7222 \\
Dick.L.Gebhart@usace.army.mil
\end{tabular} & Data analysis \\
\hline $\begin{array}{l}\text { Larry } \\
\text { Holzworth } \\
\text { (retired) }\end{array}$ & $\begin{array}{l}\text { USDA-NRCS. Federal BIdg, } \\
\text { Rm } 443 \\
10 \text { East Babcock St } \\
\text { Bozeman, MT 59715-4704 }\end{array}$ & & $\begin{array}{l}\text { Monitoring } \\
\text { demonstration } \\
\text { plots }\end{array}$ \\
\hline $\begin{array}{l}\text { Susan Hardy } \\
\text { (retired) }\end{array}$ & $\begin{array}{l}\text { ERDC-CRREL } \\
72 \text { Lyme Road } \\
\text { Hanover, NH } 03755\end{array}$ & & $\begin{array}{l}\text { Project planning, } \\
\text { documentation }\end{array}$ \\
\hline Janet Clark & $\begin{array}{l}\text { Center for Invasive Plant } \\
\text { Management (CIPM) } \\
\text { Montana State University } \\
\text { P.O. Box } 173120 \\
\text { Bozeman, MT } 59717\end{array}$ & \begin{tabular}{|l} 
(406) 994-6832 \\
Fax: (406) 994-1889 \\
cipm@montana.edu
\end{tabular} & $\begin{array}{l}\text { Promoting the } \\
\text { ecological bridge } \\
\text { concept }\end{array}$ \\
\hline Dustin Kafka & $\begin{array}{l}\text { Wyoming NGB } \\
5500 \text { Bishop Blvd. } \\
\text { Cheyenne WY } 82001-3320\end{array}$ & $\begin{array}{l}\text { (307) 836-7785 } \\
\text { dustin.kafka@us.army.mil }\end{array}$ & $\begin{array}{l}\text { Monitoring } \\
\text { demonstration } \\
\text { plots }\end{array}$ \\
\hline Peter Nissen & $\begin{array}{l}\text { Directorate of Environment } \\
\text { and Natural Resources } \\
\text { ATTN: Pete Nissen } \\
\text { Building } 810 \\
\text { Yakima Training Center } \\
\text { Yakima, WA } 98901\end{array}$ & \begin{tabular}{|l|} 
(509) 577-3500 \\
Fax: (509) 577-3336 \\
peter.nissen@us.army.mil
\end{tabular} & Site sponsor (YTC) \\
\hline
\end{tabular}




\title{
Appendix B: Decision Paper on Public Releases for the Germplasms Developed under the SERDP and ESTCP Programs
}

\author{
Authors: Antonio J. Palazzo, Kevin B. Jensen, and Susan E. Hardy
}

\section{B.1 Introduction}

The objective of this white paper is to provide a rationale for our choice of public releases as the most cost-effective and efficient method to get our plants in use on military lands. The germplasms were developed mainly under the SERDP/ESTCP programs during the last 8 years. Under the SERDP project SI-1103, we conducted basic and applied research to develop plant germplasms more resilient to military training activities. Under ESTCP project SI-0401, we are demonstrating the resiliency of these germplasms either alone or in mixtures on military lands.

\section{B.2 Project summary}

We bred native and introduced plant species with modified traits related to resiliency and establishment on military lands. Our improved plant materials are ecologically compatible to military sites because they were developed on and from collections of species native to or previously seeded at these sites. We have published widely on various topics related to the concepts and methods, genetics, releases, and performance and resiliency of the species. Our studies on "ecological bridges" confirm that we can select seed mixtures that will establish more rapidly than all-native mixes, allow earlier land use for training, and ultimately lead to healthy and persistent stands of native plants. The species in the seed mixtures and the equipment needed are readily available and the seeding can be done in one application, thus saving money. Our modified germplasms will make these seeding mixes even more desirable.

The overall objectives of the projects were to:

- breed modified native and introduced plant germplasms that have increased persistence and establishment characteristics under military training activities; 
- understand the effects of training on soil compaction, plant injury, and regrowth;

- evaluate seeding methodology to better establish native and noninvasive non-native grasses in mixed stands while promoting resistance to invasion by non-native invasive plants.

\section{B.3 Business plan}

In 2002, we prepared a business plan describing our efforts to transfer this technology to commercial seed development so that the new plant materials and associated seeding methods may be readily available to military and other federal land managers. Our technology-transfer approach includes (1) demonstrating the advantage of the new germplasms and (2) developing a seed market for dispersal. To meet the demonstration objective, we established and monitored demonstration plots at selected installations to show the benefits of these new germplasms to private and public land managers, users, and seed producers. For marketing, we have been giving presentations relating to plant establishment, management, and ecological parameters of the new germplasms.

\section{B.4 Marketing}

Our marketing efforts for all the new germplasms are aimed at creating and promoting demand to show seed producers that it is commercially viable to produce the seed of these species. We have promoted the important beneficial characteristics of the species to military lands managers in the field, command managers, Army Environmental Center (AEC), and other managerial types. To produce even more demand, we have also discussed the use of these with the Bureau of Land Management (BLM) and other federal agencies that purchase large quantities of seed. We have visited a seed production company and made a presentation to the National Seed Producers Association as well as at numerous professional meetings.

We anticipate that our work will provide a better return on the military investment. Within the range of distributions for the new germplasms, we have identified 42 DoD facilities, which include over 525,00o hectares (1.3 million acres) of Army and Air Force land. The new germplasms are also appropriate for other federal, state, or local agencies; highway rights-ofway; mine spoils; rangelands; and other disturbed areas. 


\section{B.5 Seed production}

In 2002 we contracted with the USDA-NRCS in Aberdeen, Idaho, to produce seed of three SERDP-developed species: western wheatgrass, slender wheatgrass, and Siberian wheatgrass. (The initial seed production of approximately $2,000 \mathrm{lb}$ was distributed free to selected military installations in February 2007 after this white paper was written.)

\section{B.6 Release process}

All plant releases adhere to requirements set forth for publicly or privately released plant materials under a Plant Variety Protection (PVP) agreement according to USDA-ARS and CRREL protocol. We proposed that the seed be formally released in joint ownership with USDA-ARS and Army (CRREL) with appropriate recognition given to SERDP for providing partial financial support in the development of these plant materials (see release notice write-up). Foundation seed will be produced and maintained by the USDA-ARS-Forage and Range Research Lab and made available to the public for certified seed production through the Utah Crop Improvement Association.

\section{B.7 Private vs. public release}

A major question now that the germplasms are close to being used in the field is to determine if they should be released publicly or privately. There are benefits and detriments with each method. The major benefit to a public release is that certified seed can be produced by any private seed grower without licensing. Directly related to the rapid acceptance of new revegetation (dryland) grasses on the market is the ability to have large amounts of seed available at the time of official release. The major drawback to a public release is the lack of advertising by one company trying to market the material. However, we do not feel that this alone justifies a private (licensed) release of this material. A private release might produce royalties for seed sales to non-government entities and it would allow us to control which seed companies receive the license to grow the seed, but that does not guarantee that the company will actually ever grow the seed for sale. Most seed produced through private-release government contracts is for use in limited areas. Seed producers are not accustomed to producing seed for the general market under government contracts. The amount of seed to be sold to the military is small compared to the entire market. There are greater sales potential for seed produced 
for grazing lands and reseeding after fires, and our new germplasms could be very useful for these demands. A public release appears to be the best method of insuring that our cultivars are produced and available for the widest possible market.

\section{B.8 Conclusions}

Regardless of whether seed is released publicly or privately, we can control the quality of the seed by requiring that only certified seed be produced via PVP protection. In considering all factors, it would be most cost-effective to the military, government, and private users to release these plant materials (cultivars only) publicly with PVP protection to ensure that only certified seed be sold on the market. Foundation seed for the production of certified seed can be obtained through Utah Crop Improvement Association. 


\section{Appendix C: Germplasm Release Types and Requirements}

Early in the ESTCP project, we prepared a white paper (reprinted in Appendix B) describing the reasons for the various releases of the SERDPselect germplasms as a cultivar, source identified, selected, or tested class of germplasm. The conclusions of the white paper were:

Regardless of whether seed is released publicly or privately, we can control the quality of the seed by requiring that only certified seed be produced via PVP protection. In considering all factors, it would be most cost-effective to the military, government, and private users to release these plant materials (cultivars only) publicly with PVP protection to ensure that only certified seed be sold on the market. Foundation seed for the production of certified seed can be obtained through Utah Crop Improvement Association.

Under the ESTCP program, four SERDP-select plant germplasms were released as cultivars with potential for Plant Variety Protection (PVP), based on their breeding history and their response to selection for seedling vigor, persistence, and ability to regrow after disturbance (two cultivars were released earlier under our SERDP funding). A minimum level of significance was set at alpha $=0.05$, and SERDP-select materials were tested against these criteria.

Pre-variety germplasms require less (or no) testing to justify release. Prevariety germplasm categories (AOSCA 2003) are:

- Source-identified class: an unevaluated germplasm, identified only as to species and location of the wild growing parents.

- Selected class: germplasm shows promise of desirable traits, having been selected either within or as a common site comparison among accessions or populations of the same species.

- Tested class: germplasm for which progeny testing has proven desirable traits to be heritable. 
Progeny testing data for cultivar release must encompass two locations (environments) or 2 years of data. Additionally, an application for PVP Certificate (USDA form GR-470, available at [accessed June 2009] www.ams.usda.gov/science/pvpo/Forms/forms.htm) must include:

Exhibit A. Breeding history. To include the following:

1. A full disclosure of the genealogy back to publicly known varieties, lines, or clones, including the breeding method;

2. The details of subsequent stages of selection and multiplication used to develop the variety;

3. A statement of uniformity reporting the level of variability in any characteristics of the variety (commercially acceptable variability is allowed);

4. A statement of genetic stability showing the number of cycles of seed reproduction for which the variety has remained unchanged in all distinguishing characteristics; and

5. The type and frequency of variants observed during reproduction and multiplication.

Exhibit B. Statement of distinctiveness. This must clearly state how the application variety may be distinguished from other varieties of the same species. It must:

1. Identify the most similar variety or group of varieties and state all differences objectively;

2. Attach statistical data for characters expressed numerically and demonstrate that these are clear differences; and

3. Submit, if helpful, seed and plant specimens or photographs (prints) of seed and plant comparisons that clearly indicate distinctness.

Exhibit C. Objective description of the variety. For example, resistance to disease, establishment rate, and plant persistence.

Exhibit D. Optional supporting information. The applicant may provide additional information, specimens, and/or materials in support of the claims of the application.

Exhibit E. Statement of basis of ownership. 
The general chronology for the release of a germplasm or cultivar is that a release notice, including release type and all supporting data, is first prepared for approval by the agency or agencies developing the plant material (in this case, ERDC-CRREL and the USDA-ARS). After their approval, the release notice is brought before either the AOSCA or State Certification Board to get the material into the seed certification program. After approval of each release, an article is submitted to Crop Science or the J ournal of Plant Registrations to announce the release.

Preliminary decisions about the appropriate release type for each SERDPselect population of plants as a cultivar or germplasm were based on breeding history, the unique differences observed in these plants in the later generations in the breeding process, and the potential demand in the marketplace. As we developed the plants, we adjusted release decisions for any and all germplasms based on the physiological and genetic data collected. We released the SERDP-select germplasms of western wheatgrass, slender wheatgrass, Russian wildrye, and Siberian wheatgrass as cultivars, with release notices in 2006 through 2009; the final PVP application process is usually completed within 2 years. Because they are broad-based collections with little or no selective breeding applied, the Sandberg bluegrass and yarrow germplasms were released as either source-identified or selected-class pre-variety germplasms in 2004 or 2005. We used this demonstration program to advance our remaining germplasms as far as possible toward release as cultivars. 


\section{Appendix D: Data}

This appendix contains additional data or more detailed data than are shown in the bulk of this report.

\section{D.1 Results of preliminary evaluation trials to identify promising species (1994-1996)}

At the beginning of the SERDP program, many more species were examined and eventually dropped (based on adaptive characteristics) as the most promising species became apparent. We began with evaluation trials at two U.S. Army sites to help identify promising germplasms. The evaluation trials to assess stand establishment were conducted at Fort Carson in south-central Colorado and at the Yakima Training Center (YTC) in south-central Washington. The trials were established during the fall of 1994 and 1996. The seeded evaluation sites at the facilities differed in soil type and precipitation, which allowed for evaluation of germplasms over different environmental regimes (Table 33).

Table 33. Precipitation and soil types at species-evaluation sites.

\begin{tabular}{|llll|}
\hline Location & Site & Annual precipitation & Soil type \\
\hline Yakima, Washington & Snake A and B & $200-250 \mathrm{~m}$ & Benwy series \\
\hline Fort Carson, Colorado & Turkey Creek & $300-350 \mathrm{~mm}$ & Rizozo-Neville Complex \\
& South Boundary & $175-225 \mathrm{~mm}$ & $\begin{array}{l}\text { Minnequa-Manvel } \\
\text { loams }\end{array}$ \\
& & & \\
\hline
\end{tabular}

Two evaluation trials were conducted at Fort Carson: Turkey Creek (TC) and South Boundary (SB). The soils at SB are shallower, much drier, and less fertile than those at the TC site. Both sites received less than normal precipitation during our trials, especially in the latter years. The following two tables show the stand establishment results over successive years (Table 34 and Table 35). 
Table 34. Stand establishment of perennial grasses at Fort Carson Turkey Creek Site, seeded fall 1994.

\begin{tabular}{|c|c|c|c|c|c|}
\hline \multirow[b]{2}{*}{ Entry } & \multicolumn{5}{|c|}{ Mean \% stand } \\
\hline & 1997 & 1998 & 1999 & 2000 & 2001 \\
\hline \multicolumn{6}{|l|}{ Introduced entries: } \\
\hline \multicolumn{6}{|l|}{ Crested wheatgrass } \\
\hline CD-II crested wheatgrass & 100 & 97 & 94 & 89 & 99 \\
\hline RoadCrest crested wheatgrass & 91 & 100 & 100 & 92 & 93 \\
\hline \multicolumn{6}{|l|}{ Siberian wheatgrass } \\
\hline P27 Siberian wheatgrass & 84 & 100 & 94 & 91 & 90 \\
\hline Vavilov Siberian wheatgrass & 83 & 97 & 88 & 80 & 95 \\
\hline Kazakhstan Siberian wheatgrass & 73 & 94 & 78 & 69 & 83 \\
\hline \multicolumn{6}{|l|}{ Russian wildrye } \\
\hline Tetraploid Russian wildrye & 68 & 94 & 91 & 78 & 93 \\
\hline Mankota Russian wildrye & 46 & 91 & 88 & 72 & 89 \\
\hline Bozoisky Russian wildrye & 30 & 84 & 81 & 64 & 86 \\
\hline \multicolumn{6}{|l|}{ Native entries: } \\
\hline \multicolumn{6}{|l|}{ Thickspike wheatgrass } \\
\hline Sodar thickspike wheatgrass & 55 & 91 & 84 & 80 & 93 \\
\hline E27 thickspike wheatgrass & 52 & 81 & 75 & 66 & 77 \\
\hline \multicolumn{6}{|l|}{ Indian ricegrass } \\
\hline Paloma Indian ricegrass & 31 & 56 & 47 & 30 & 28 \\
\hline T593 Indian ricegrass & 13 & 38 & 31 & 19 & 28 \\
\hline Nezpar Indian ricegrass & 26 & 25 & 19 & 23 & 12 \\
\hline CSU10 Indian ricegrass & 9 & 22 & 16 & 16 & 25 \\
\hline \multicolumn{6}{|l|}{ Miscellaneous species } \\
\hline Rosana western wheatgrass & 54 & 81 & 100 & 97 & 100 \\
\hline Needle and thread grass & 5 & 31 & 47 & 45 & 51 \\
\hline Alma blue grama & 0 & 0 & 31 & 22 & 15 \\
\hline Vaughan sideoats grama & 0 & 0 & 19 & 19 & 15 \\
\hline LSD (0.05) entries & 8 & 16 & 18 & 16 & 14 \\
\hline
\end{tabular}


Table 35. Mean percent stand of native and introduced grasses at Fort Carson South Boundary, seeded fall 1996.

\begin{tabular}{|c|c|c|c|c|c|}
\hline \multirow[b]{2}{*}{ Entry } & \multicolumn{5}{|c|}{ Mean \% stand } \\
\hline & 1997 & 1998 & 1999 & 2000 & 2001 \\
\hline \multicolumn{6}{|l|}{ Introduced entries: } \\
\hline \multicolumn{6}{|l|}{ Russian wildrye } \\
\hline Bozoisky & 63 & 93 & 94 & 81 & 91 \\
\hline Tetraploid & 59 & 88 & 78 & 70 & 88 \\
\hline Syn A & 66 & 88 & 84 & 78 & 86 \\
\hline Mankota & 72 & 78 & 88 & 80 & 85 \\
\hline \multicolumn{6}{|l|}{ Crested wheatgrass } \\
\hline CD-II & 69 & 41 & 47 & 37 & 30 \\
\hline RoadCrest & 88 & 94 & 91 & 83 & 91 \\
\hline \multicolumn{6}{|l|}{ Siberian wheatgrass } \\
\hline Vavilov & 81 & 81 & 78 & 64 & 78 \\
\hline Kazak & 56 & 69 & 63 & 52 & 55 \\
\hline \multicolumn{6}{|l|}{ Intermediate wheatgrass } \\
\hline Luna & 28 & 9 & 16 & 7 & 3 \\
\hline Rush & 34 & 6 & 13 & 1 & 1 \\
\hline \multicolumn{6}{|l|}{ Native entries: } \\
\hline \multicolumn{6}{|l|}{ Western wheatgrass } \\
\hline Barton & 63 & 50 & 72 & 69 & 88 \\
\hline Rodan & 63 & 44 & 53 & 42 & 58 \\
\hline Rosana & 41 & 34 & 53 & 50 & 78 \\
\hline \multicolumn{6}{|l|}{ Thickspike wheatgrass } \\
\hline $\mathrm{E}-27$ & 25 & 3. & 6 & 3 & 4 \\
\hline Sodar & 28 & 13 & 3 & 8 & 14 \\
\hline \multicolumn{6}{|l|}{ Miscellaneous species } \\
\hline Pryor slender wheatgrass & 72 & 38 & 31 & 7 & 0 \\
\hline Bottlebrush squirreltail & 34 & 6 & 3 & 4 & 2 \\
\hline Sandhollow & 25 & 9 & 9 & 4 & 3 \\
\hline Sand lovegrass & 31 & 3 & 16 & 0 & 0 \\
\hline Overall mean & 53 & 45 & 47 & 39 & 44 \\
\hline LSD (0.05) & 18 & 23 & 20 & 15 & 18 \\
\hline
\end{tabular}

At YTC, evaluation trials were conducted on adjacent Snake River sites A and B. The YTC location received 353, 375, 175, and $193 \mathrm{~mm}$ in 1995, 1996, 1997, and 1998, respectively. Results are shown in the next two tables Table 36 and Table 37. 
Table 36. Seeding vigor ratings and percent stand of native and introduced perennial Triticeae grasses during stand establishment (1995) and subsequent years on Snake A site at Yakima Training Center.

\begin{tabular}{|c|c|c|c|c|c|}
\hline Entry & $\begin{array}{c}\text { Seedling vigor z } \\
\text { May } 1995\end{array}$ & $\begin{array}{c}\text { \% Stand } \mathrm{y} \\
1995\end{array}$ & $\begin{array}{c}\text { \% Stand } \\
1996\end{array}$ & $\begin{array}{c}\text { \% Stand } \\
1997\end{array}$ & $\begin{array}{c}\text { \% Stand } \\
1998\end{array}$ \\
\hline \multicolumn{6}{|l|}{ Snake A Introduced Entries } \\
\hline \multicolumn{6}{|l|}{ Siberian wheatgrass } \\
\hline Vavilov Siberian wheatgrass $^{\top}$ & 9 & 99 & 100 & 100 & 100 \\
\hline P-27 Siberian wheatgrass ${ }^{\top}$ & 9 & 96 & 82 & 83 & 88 \\
\hline Kazak Siberian wheatgrass $^{\top}$ & 7 & 75 & 66 & 80 & 72 \\
\hline Mean & 8 & 90 & 83 & 88 & 87 \\
\hline \multicolumn{6}{|l|}{ Crested wheatgrass } \\
\hline Hycrest $^{\top}$ & 7 & 94 & 82 & 69 & 79 \\
\hline Ephraim $^{\top}$ & 8 & 77 & 69 & 71 & 75 \\
\hline Mean & 7 & 85 & 75 & 70 & 77 \\
\hline \multicolumn{6}{|l|}{ Russian wildrye } \\
\hline Bozoisky $^{\top}$ & 5 & 67 & 57 & 55 & 63 \\
\hline Tetraploid $^{\mathrm{T}}$ & 4 & 50 & 25 & 38 & 38 \\
\hline Mean & 4 & 59 & 41 & 46 & 50 \\
\hline Intermediate wheatgrass (cv. Luna) ${ }^{T}$ & 4 & 61 & 72 & 77 & 78 \\
\hline \multicolumn{6}{|l|}{ Snake A Native Entries } \\
\hline \multicolumn{6}{|l|}{ Wildryes) } \\
\hline Leymus-1 hybrid & 1 & 8 & 0 & 3 & 7 \\
\hline${\text { Basin wildrye }\left(\text { Yakima }^{\top}\right.}^{\top}$ & 3 & 35 & 13 & 34 & 38 \\
\hline Mean & 1 & 21 & 7 & 19 & 22 \\
\hline \multicolumn{6}{|l|}{ Bluegrasses } \\
\hline Canby bluegrass $^{\top}$ & 8 & 69 & 70 & 60 & 82 \\
\hline Sandberg bluegrass & 7 & 49 & 50 & 51 & 54 \\
\hline Mean & 7 & 59 & 53 & 32 & 68 \\
\hline \multicolumn{6}{|l|}{ Indian ricegrass } \\
\hline Nezpar Indian ricegrass & 6 & 60 & 10 & 0 & 10 \\
\hline T553 Indian ricegrass & 1 & 11 & 3 & 0 & 16 \\
\hline \begin{tabular}{r|} 
Mean \\
\end{tabular} & 3 & 35 & 7 & 0 & 13 \\
\hline \begin{tabular}{|l|l|} 
Western wheatgrass (cv. Rosana) & ${ }^{\top}$ \\
\end{tabular} & 3 & 33 & 35 & 32 & 41 \\
\hline \multicolumn{6}{|l|}{ Bottlebrush } \\
\hline Squirrel tail 87 & 3 & 41 & 41 & 0 & 0 \\
\hline Squirrel tail 89 & 6 & 55 & 47 & 0 & 0 \\
\hline Mean & 4 & 48 & 44 & 0 & 0 \\
\hline \multicolumn{6}{|l|}{ Miscellaneous species } \\
\hline Needle and thread grass & 2 & 14 & 0 & 8 & 6 \\
\hline SL hybrid (thickspike X bluebunch) & 4 & 46 & 57 & 34 & 50 \\
\hline Mean & 2 & 30 & 28 & 21 & 28 \\
\hline LSD (0.05)-Entries & 1 & 19 & 14 & 12 & 14 \\
\hline LSD (0.05)-Species & 2 & 20 & 18 & 17 & 17 \\
\hline
\end{tabular}

z Seedling vigor ratings 9 May 1995, following a dormant fall seeding in 1994; 1=poor, 9=best seedling vigor.

y Percent stand based on visual ratings.

T Entries included in the tracking study 
Table 37. Seeding vigor ratings and percent stand of native and introduced perennial Triticeae grasses during stand establishment (1995) and subsequent years on Snake B site at Yakima Training Center.

\begin{tabular}{|c|c|c|c|c|c|}
\hline Snake B Native Entries & $\begin{array}{c}\text { Seedling vigor z } \\
\text { May } 1995\end{array}$ & $\begin{array}{c}\text { \% Stand } \\
1995\end{array}$ & $\begin{array}{c}\text { \% Stand } \\
1996\end{array}$ & $\begin{array}{c}\text { \% Stand } \\
1997\end{array}$ & $\begin{array}{c}\text { \% Stand } \\
1998\end{array}$ \\
\hline \multicolumn{6}{|l|}{ Bluebunch wheatgrass } \\
\hline Goldar $^{\top}$ & 7.0 & 67 & 56 & 49 & 75 \\
\hline Whitmar $^{\top}$ & 6.3 & 66 & 72 & 62 & 75 \\
\hline${\text { ACC- }-238^{\top}}^{\top}$ & 6.0 & 70 & 53 & 53 & 75 \\
\hline Yakima collection $^{\top}$ & 6.5 & 59 & 38 & 45 & 69 \\
\hline Mean & 6.4 & 66 & 55 & 52 & 73 \\
\hline \multicolumn{6}{|l|}{ Snake River wheatgrass } \\
\hline Secar $^{\top}$ & 7.3 & 69 & 94 & 92 & 97 \\
\hline ACC-707 T & 7.0 & 75 & 88 & 75 & 91 \\
\hline EVT-572 ${ }^{\top}$ & 7.5 & 73 & 91 & 87 & 100 \\
\hline Mean & 7.3 & 72 & 91 & 85 & 96 \\
\hline \multicolumn{6}{|l|}{ Thickspike wheatgrass and hybrids } \\
\hline Bannock $^{\top}$ & 7.3 & 73 & 72 & 53 & 75 \\
\hline Sodar & 6.5 & 64 & 41 & 35 & 41 \\
\hline E-20 (thickspike X Snake River) ${ }^{\top}$ & 7.0 & 72 & 78 & 80 & 88 \\
\hline E-27 (thickspike X Snake River) ${ }^{\top}$ & 6.5 & 70 & 81 & 69 & 81 \\
\hline SL hybrid (thickspike X bluebunch) & 4.3 & 52 & 22 & 23 & 28 \\
\hline Mean & 6.3 & 66 & 59 & 52 & 63 \\
\hline LSD (0.05)-Entries & 1 & 14 & 16 & 11 & 10 \\
\hline LSD (0.05)-Species & 0.6 & 8 & 15 & 12 & 13 \\
\hline
\end{tabular}

${ }^{\mathrm{z}}$ Seedling vigor ratings 9 May 1995, following a dormant fall seeding in 1994; $1=$ poor, $9=$ =best seedling vigor.

y Percent stand based on visual ratings.

${ }^{\mathrm{T}}$ Entries included in the tracking study

\section{D.2 Yakima Training Center seeding list (monocultures and mixtures)}

The site Exit 11 site at Yakima Training Center was seeded on 21-22 October 2002 (Table 38). Plots are $1.5 \times 24 \mathrm{~m}(5 \times 80 \mathrm{ft})$ with six rows at $2.5 \mathrm{~cm}$ (10 in.) apart. Seeds were placed $1.25-2.0 \mathrm{~cm}$ below the soil surface at a rate of approximately one seed/cm (2.5 seeds per linear inch). Plots were arranged in randomized complete blocks with four replications. 
There were 9-m wide borders of Hycrest crested wheatgrass between replications. Plots were oriented east to west.

Table 38. YTC Exit 11 monoculture and mixture seeding list (21-22 October 2002).

\begin{tabular}{|c|c|c|}
\hline Plot & Entry & $\operatorname{Rep}$ \\
\hline 10 & BBWG-SERDP & 1 \\
\hline 16 & BBWG-SERDP & 2 \\
\hline 9 & BBWG-SERDP & 3 \\
\hline 11 & BBWG-SERDP & 4 \\
\hline 5 & BOZXTET & 1 \\
\hline 12 & BOZXTET & 2 \\
\hline 15 & BOZXTET & 3 \\
\hline 3 & BOZXTET & 4 \\
\hline 9 & GOLDAR & 1 \\
\hline 10 & GOLDAR & 2 \\
\hline 8 & GOLDAR & 3 \\
\hline 14 & GOLDAR & 4 \\
\hline 19 & MIX-1 & 1 \\
\hline 4 & MIX-1 & 2 \\
\hline 17 & MIX-1 & 3 \\
\hline 20 & MIX-2 & 1 \\
\hline 2 & MIX-2 & 2 \\
\hline 7 & MIX-2 & 3 \\
\hline 10 & MIX-2 & 4 \\
\hline 11 & PRYOR & 1 \\
\hline 20 & PRYOR & 2 \\
\hline 19 & PRYOR & 3 \\
\hline 16 & PRYOR & 4 \\
\hline 3 & ROADCREST & 1 \\
\hline 5 & ROADCREST & 2 \\
\hline 2 & ROADCREST & 3 \\
\hline 2 & ROADCREST & 4 \\
\hline 13 & ROSANA & 1 \\
\hline 17 & ROSANA & 2 \\
\hline 11 & ROSANA & 3 \\
\hline 19 & ROSANA & 4 \\
\hline 16 & SAND-SERDP & 1 \\
\hline 11 & SAND-SERDP & 2 \\
\hline 14 & SAND-SERDP & 3 \\
\hline
\end{tabular}

\begin{tabular}{|c|c|c|}
\hline Plot & Entry & $\operatorname{Rep}$ \\
\hline 7 & SECAR & 1 \\
\hline 7 & SECAR & 2 \\
\hline 1 & $\overline{\text { SECAR }}$ & 3 \\
\hline 18 & SECAR & 4 \\
\hline 12 & SLEN-SERDP & 1 \\
\hline 6 & SLEN-SERDP & 2 \\
\hline 13 & SLEN-SERDP & 3 \\
\hline 8 & SRWG-SERDP & 1 \\
\hline 3 & SRWG-SERDP & 2 \\
\hline 10 & SRWG-SERDP & 3 \\
\hline 20 & SRWG-SERDP & 4 \\
\hline 4 & SYNA & 1 \\
\hline 8 & SYNA & 2 \\
\hline 20 & SYNA & 3 \\
\hline 15 & SYNA & 4 \\
\hline 6 & TRAILHEAD & 1 \\
\hline 14 & TRAILHEAD & 2 \\
\hline 6 & TRAILHEAD & 3 \\
\hline 13 & TRAILHEAD & 4 \\
\hline 2 & VAV-SERDP & 1 \\
\hline 1 & VAV-SERDP & 2 \\
\hline 16 & VAV-SERDP & 3 \\
\hline 4 & VAV-SERDP & 4 \\
\hline 1 & VAVILOV & 1 \\
\hline 15 & VAVILOV & 2 \\
\hline 5 & VAVILOV & 3 \\
\hline 14 & WWG-SERDP & 1 \\
\hline 19 & WWG-SERDP & 2 \\
\hline 3 & WWG-SERDP & 3 \\
\hline 8 & WWG-SERDP & 4 \\
\hline 18 & WY-SERDP & 1 \\
\hline 9 & WY-SERDP & 2 \\
\hline 12 & WY-SERDP & 3 \\
\hline 9 & WY-SERDP & 4 \\
\hline
\end{tabular}




\begin{tabular}{|r|l|c|}
\hline \multicolumn{1}{|l|}{ Plot } & Entry & Rep \\
\hline 1 & SAND-SERDP & 4 \\
\hline 15 & SAND-CK & 1 \\
\hline 18 & SAND-CK & 2 \\
\hline 4 & SAND-CK & 3 \\
\hline 17 & SAND-CK & 4 \\
\hline
\end{tabular}

\begin{tabular}{|c|l|c|}
\hline Plot & Entry & Rep \\
\hline 17 & WY-CK & 1 \\
\hline 13 & WY-CK & 2 \\
\hline 18 & WY-CK & 3 \\
\hline 12 & WY-CK & 4 \\
\hline & & \\
\hline
\end{tabular}

\section{D.3 Camp Guernsey seeding lists (monocultures and mixtures)}

Guernsey River Site. The River site is near the North Platte River $\left(\mathrm{N} 42^{\circ} 15.001^{\prime} \mathrm{W} 104^{\circ} 44.090^{\prime}\right)$. Monocultures and mixtures were planted on 31 March 2004, with a plot size of $1.5 \times 6 \mathrm{~m}(5 \times 20 \mathrm{ft})$ with six rows at $2.5 \mathrm{~cm}$ (10 in.) apart (Table 39). There were $1.5-\mathrm{m}$ ( 5 -ft) borders of CD-II crested wheatgrass between replications. Starting in the southwest corner, rows were numbered form west to east; replications were numbered from south to north. Monoculture seeds were planted at a rate of approximately one seed/cm (2.5 seeds per linear inch). See Table 5 and Table 6 in Section 5.3.2 for mixture species and seeding rates.

Table 39. Guernsey River site monoculture and mixture seeding list (31 March 2004).

\begin{tabular}{|l|r|l|}
\hline Entry & Row & Rep \\
\hline Al Intermediate WG & 25 & 1 \\
\hline Al Intermediate WG & 5 & 2 \\
\hline Al Intermediate WG & 9 & 3 \\
\hline Bannock Thickspike WG & 29 & 1 \\
\hline Bannock Thickspike WG & 8 & 2 \\
\hline Bannock Thickspike WG & 5 & 3 \\
\hline Bozoisky RWR & 2 & 1 \\
\hline Bozoisky RWR & 10 & 2 \\
\hline Bozoisky RWR & 4 & 3 \\
\hline Bozoisky X Tetra RWR & 1 & 1 \\
\hline Bozoisky X Tetra RWR & 28 & 2 \\
\hline Bozoisky X Tetra RWR & 12 & 3 \\
\hline Camper Little Bluestem & 31 & 1 \\
\hline Camper Little Bluestem & 34 & 2 \\
\hline Camper Little Bluestem & 24 & 3 \\
\hline Flintlock Western WG & 15 & 1 \\
\hline Flintlock Western WG & 32 & 2 \\
\hline
\end{tabular}

\begin{tabular}{|l|r|l|}
\hline Entry & Row & Rep \\
\hline P-7 Bluebunch WG & 12 & 1 \\
\hline P-7 Bluebunch WG & 15 & 2 \\
\hline P-7 Bluebunch WG & 20 & 3 \\
\hline Pryor Slender WG & 4 & 1 \\
\hline Pryor Slender WG & 24 & 2 \\
\hline Pryor Slender WG & 1 & 3 \\
\hline Roadcrest Crested WG & 7 & 1 \\
\hline Roadcrest Crested WG & 14 & 2 \\
\hline Roadcrest Crested WG & 21 & 3 \\
\hline Rosana Western WG & 17 & 1 \\
\hline Rosana Western WG & 19 & 2 \\
\hline Rosana Western WG & 18 & 3 \\
\hline SB-2 Western WG & 16 & 1 \\
\hline SB-2 Western WG & 22 & 2 \\
\hline SB-2 Western WG & 7 & 3 \\
\hline Secar Snake River WG & 13 & 1 \\
\hline Secar Snake River WG & 18 & 2 \\
\hline
\end{tabular}




\begin{tabular}{|l|c|l|}
\hline Entry & Row & Rep \\
\hline Flintlock Western WG & 19 & 3 \\
\hline Goldar Bluebunch WG & 11 & 1 \\
\hline Goldar Bluebunch WG & 31 & 2 \\
\hline Goldar Bluebunch WG & 23 & 3 \\
\hline Kazak Pub. Siberian WG & 8 & 1 \\
\hline Kazak Pub. Siberian WG & 20 & 2 \\
\hline Kazak Pub. Siberian WG & 14 & 3 \\
\hline Lovington Blue Grama & 27 & 1 \\
\hline Lovington Blue Grama & 25 & 2 \\
\hline Lovington Blue Grama & 30 & 3 \\
\hline Mix 1 - Introduced & 23 & 1 \\
\hline Mix 1 - Introduced & 6 & 2 \\
\hline Mix 1 - Introduced & 11 & 3 \\
\hline Mix 2 - Native & 24 & 1 \\
\hline Mix 2 - Native & 17 & 2 \\
\hline Mix 2 - Native & 25 & 3 \\
\hline Mix 3 - Guernsey & 26 & 1 \\
\hline Mix 3 - Guernsey & 27 & 2 \\
\hline Mix 3 - Guernsey & 6 & 3 \\
\hline Mix 4 - core native & 28 & 1 \\
\hline Mix 4 - core native & 21 & 2 \\
\hline Mix 4 - core native & 32 & 3 \\
\hline Mix 5 - core + Al IWG & 30 & 1 \\
\hline Mix 5 - core + Al IWG & 3 \\
\hline Mix 5 - core + Al IWG & 2 \\
\hline Mix 6 - core + SERDP Sib.WG & 3 \\
\hline Mix 6 - core + SERDP Sib.WG & 2 \\
\hline Mix 6 - core + SERDP Sib.WG & 2 \\
\hline Mix 7 - core + SERDP RWR & 3 \\
\hline Mix 7 - core + SERDP RWR & 2 \\
\hline Mix 7 - core + SERDP RWR & 17 \\
\hline
\end{tabular}

\begin{tabular}{|l|c|l|}
\hline Entry & Row & Rep \\
\hline Secar Snake River WG & 26 & 3 \\
\hline SERDP Basin WR & 20 & 1 \\
\hline SERDP Basin WR & 23 & 2 \\
\hline SERDP Basin WR & 3 & 3 \\
\hline SERDP Slender WG & 5 & 1 \\
\hline SERDP Slender WG & 12 & 2 \\
\hline SERDP Slender WG & 34 & 3 \\
\hline $\begin{array}{l}\text { SERDP Slender WG - } \\
\text { Rhiz. }\end{array}$ & 6 & 1 \\
\hline $\begin{array}{l}\text { SERDP Slender WG - } \\
\text { Rhiz. }\end{array}$ & 3 & 2 \\
\hline $\begin{array}{l}\text { SERDP Slender WG - } \\
\text { Rhiz. }\end{array}$ & 15 & 3 \\
\hline SERDP Snake River WG & 14 & 1 \\
\hline SERDP Snake River WG & 9 & 2 \\
\hline SERDP Snake River WG & 2 & 3 \\
\hline SERDP Syn A RWR & 3 & 1 \\
\hline SERDP Syn A RWR & 11 & 2 \\
\hline SERDP Syn A RWR & 33 & 3 \\
\hline SERDP TC-2 Western WG & 18 & 1 \\
\hline SERDP TC-2 Western WG & 7 & 2 \\
\hline SERDP TC-2 Western WG & 13 & 3 \\
\hline $\begin{array}{l}\text { SERDP Vavilov Siberian } \\
\text { WG }\end{array}$ & 10 & 1 \\
\hline $\begin{array}{l}\text { SERDP Vavilov Siberian } \\
\text { WG }\end{array}$ & 13 & 2 \\
\hline $\begin{array}{l}\text { SERDP Vavilov Siberian } \\
\text { WG }\end{array}$ & 16 & 3 \\
\hline SERDP Western Yarrow & 22 & 1 \\
\hline SERDP Western Yarrow & 4 & 2 \\
\hline SERDP Western Yarrow & 28 & 3 \\
\hline Texoka Buffalo Grass & 33 & 1 \\
\hline Texoka Buffalo Grass & 30 & 2 \\
\hline Texoka Buffalo Grass & 31 & 3 \\
\hline Trailhead Basin WR & 19 & 1 \\
\hline & & \\
\hline SER & & \\
\hline
\end{tabular}


Guernsey Tower Site. The site near the Guernsey Radar Tower $\left(\mathrm{N} 42^{\circ}\right.$ 14.385' W 104 ${ }^{\circ} 44.302^{\prime}$; elevation 1,305 $\mathrm{m}$ [4,580 ft]) was planted with monocultures and mixes 23 March 2005 (Table 40), with a plot size of 1.5

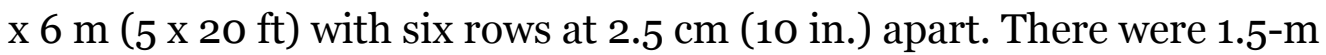
( 5 - $\mathrm{ft}$ ) borders of CD-II crested wheatgrass between replications. Starting in the southwest corner rows were numbered from west to east and replications from south to north. Monoculture seeds were planted at a rate of approximately one seed/cm (2.5 seeds per linear inch). See Table 5 and Table 6 in Section 5.3.2 for mixture species and seeding rates.

Table 40. Guernsey Tower site monoculture and mixture seedings (23 March 2005).

\begin{tabular}{|l|r|l|}
\hline Entry & Row & Rep \\
\hline Al Intermediate WG & 25 & 1 \\
\hline Al Intermediate WG & 5 & 2 \\
\hline Al Intermediate WG & 9 & 3 \\
\hline Bannock Thickspike WG & 29 & 1 \\
\hline Bannock Thickspike WG & 8 & 2 \\
\hline Bannock Thickspike WG & 5 & 3 \\
\hline Bozoisky RWR & 2 & 1 \\
\hline Bozoisky RWR & 10 & 2 \\
\hline Bozoisky RWR & 4 & 3 \\
\hline Bozoisky X Tetra RWR & 1 & 1 \\
\hline Bozoisky X Tetra RWR & 28 & 2 \\
\hline Bozoisky X Tetra RWR & 12 & 3 \\
\hline Camper Little Bluestem & 31 & 1 \\
\hline Camper Little Bluestem & 34 & 2 \\
\hline Camper Little Bluestem & 24 & 3 \\
\hline Flintlock Western WG & 15 & 1 \\
\hline Flintlock Western WG & 32 & 2 \\
\hline Flintlock Western WG & 19 & 3 \\
\hline Goldar Bluebunch WG & 11 & 1 \\
\hline Goldar Bluebunch WG & 31 & 2 \\
\hline Goldar Bluebunch WG & 23 & 3 \\
\hline Kazak Pub. Siberian WG & 8 & 1 \\
\hline Kazak Pub. Siberian WG & 20 & 2 \\
\hline Kazak Pub. Siberian WG & 14 & 3 \\
\hline Lovington Blue Grama & 27 & 1 \\
\hline Lovington Blue Grama & 25 & 2 \\
\hline
\end{tabular}

\begin{tabular}{|l|c|l|}
\hline Entry & Row & Rep \\
\hline Pryor Slender WG & 4 & 1 \\
\hline Pryor Slender WG & 24 & 2 \\
\hline Pryor Slender WG & 1 & 3 \\
\hline Roadcrest Crested WG & 7 & 1 \\
\hline Roadcrest Crested WG & 14 & 2 \\
\hline Roadcrest Crested WG & 21 & 3 \\
\hline Rosana Western WG & 17 & 1 \\
\hline Rosana Western WG & 19 & 2 \\
\hline Rosana Western WG & 18 & 3 \\
\hline SB-2 Western WG & 16 & 1 \\
\hline SB-2 Western WG & 22 & 2 \\
\hline SB-2 Western WG & 7 & 3 \\
\hline Secar Snake River WG & 13 & 1 \\
\hline Secar Snake River WG & 18 & 2 \\
\hline Secar Snake River WG & 26 & 3 \\
\hline SERDP Basin WR & 20 & 1 \\
\hline SERDP Basin WR & 23 & 2 \\
\hline SERDP Basin WR & 3 & 3 \\
\hline SERDP Slender WG & 5 & 1 \\
\hline SERDP Slender WG & 12 & 2 \\
\hline SERDP Slender WG & 34 & 3 \\
\hline SERDP Slender WG - Rhiz. & 6 & 1 \\
\hline SERDP Slender WG - Rhiz. & 3 & 2 \\
\hline SERDP Slender WG - Rhiz. & 15 & 3 \\
\hline SERDP Snake River WG & 14 & 1 \\
\hline SERDP Snake River WG & 9 & 2 \\
\hline
\end{tabular}




\begin{tabular}{|l|r|l|}
\hline Entry & Row & Rep \\
\hline Lovington Blue Grama & 30 & 3 \\
\hline Mix 1 - Introduced & 23 & 1 \\
\hline Mix 1 - Introduced & 6 & 2 \\
\hline Mix 1 - Introduced & 11 & 3 \\
\hline Mix 2 - Native & 24 & 1 \\
\hline Mix 2 - Native & 17 & 2 \\
\hline Mix 2 - Native & 25 & 3 \\
\hline Mix 3 - Guernsey & 26 & 1 \\
\hline Mix 3 - Guernsey & 27 & 2 \\
\hline Mix 3 - Guernsey & 6 & 3 \\
\hline Mix 4 - core native & 28 & 1 \\
\hline Mix 4 - core native & 21 & 2 \\
\hline Mix 4 - core native & 32 & 3 \\
\hline Mix 5 - core + Al IWG & 30 & 1 \\
\hline Mix 5 - core + Al IWG & 33 & 2 \\
\hline Mix 5 - core + Al IWG & 22 & 3 \\
\hline $\begin{array}{l}\text { Mix 6 - core + SERDP } \\
\text { Sib.WG }\end{array}$ & 32 & 1 \\
\hline $\begin{array}{l}\text { Mix 6 - core + SERDP } \\
\text { Sib.WG }\end{array}$ & 2 & 2 \\
\hline $\begin{array}{l}\text { Mix 6 - core + SERDP } \\
\text { Sib.WG }\end{array}$ & 29 & 3 \\
\hline Mix 7 - core + SERDP RWR & 34 & 1 \\
\hline Mix 7 - core + SERDP RWR & 26 & 2 \\
\hline Mix 7 - core + SERDP RWR & 17 & 3 \\
\hline P-7 Bluebunch WG & 12 & 1 \\
\hline P-7 Bluebunch WG & 20 \\
\hline P-7 Bluebunch WG & 3 \\
\hline
\end{tabular}

\begin{tabular}{|l|c|l|}
\hline Entry & Row & Rep \\
\hline SERDP Snake River WG & 2 & 3 \\
\hline SERDP Syn A RWR & 3 & 1 \\
\hline SERDP Syn A RWR & 11 & 2 \\
\hline SERDP Syn A RWR & 33 & 3 \\
\hline SERDP TC-2 Western WG & 18 & 1 \\
\hline SERDP TC-2 Western WG & 7 & 2 \\
\hline SERDP TC-2 Western WG & 13 & 3 \\
\hline $\begin{array}{l}\text { SERDP Vavilov Siberian } \\
\text { WG }\end{array}$ & 10 & 1 \\
\hline $\begin{array}{l}\text { SERDP Vavilov Siberian } \\
\text { WG }\end{array}$ & 13 & 2 \\
\hline $\begin{array}{l}\text { SERDP Vavilov Siberian } \\
\text { WG }\end{array}$ & 16 & 3 \\
\hline SERDP Western Yarrow & 22 & 1 \\
\hline SERDP Western Yarrow & 4 & 2 \\
\hline SERDP Western Yarrow & 28 & 3 \\
\hline Texoka Buffalo Grass & 33 & 1 \\
\hline Texoka Buffalo Grass & 30 & 2 \\
\hline Texoka Buffalo Grass & 31 & 3 \\
\hline Trailhead Basin WR & 19 & 1 \\
\hline Trailhead Basin WR & 29 & 2 \\
\hline Trailhead Basin WR & 27 & 3 \\
\hline Vavilov Siberian WG & 9 & 1 \\
\hline Vavilov Siberian WG & 16 & 2 \\
\hline Vavilov Siberian WG & 8 & 3 \\
\hline Western Yarrow Check & 21 & 1 \\
\hline Western Yarrow Check & 1 & 2 \\
\hline Western Yarrow Check & 10 & 3 \\
\hline
\end{tabular}

\section{D.4 Dugway Proving Ground seeding list (monocultures)}

The Dugway site was seeded with monocultures 7 November 2005 (Table 41) with a plot size of $1.5 \times 6 \mathrm{~m}(5 \times 20 \mathrm{ft})$. There were two ranges per replication and two blocks of grasses. Starting in the southeast corner, 
rows were numbered from south to north; ranges were numbered from east to west.

Table 41. Dugway monoculture seeding list (7 November 2005).

\begin{tabular}{|c|c|c|c|c|c|}
\hline $\operatorname{Rep}$ & Row & Range & Entry & Entry \# & Block \\
\hline 1 & 1 & 1 & Greenar Intermediate WG & 1 & 1 \\
\hline 1 & 2 & 1 & I 1871 Intermediate WG & 2 & 1 \\
\hline 1 & 3 & 1 & Al Intermediate WG & 3 & 1 \\
\hline 1 & 4 & 1 & Nordan - CWG & 4 & 1 \\
\hline 1 & 5 & 1 & Hycrest - CWG & 5 & 1 \\
\hline 1 & 6 & 1 & Hycrest II - Foundation Richmond & 6 & 1 \\
\hline 1 & 7 & 1 & HxB28 - Nephi 2004 (bulk selected) & 7 & 1 \\
\hline 1 & 8 & 1 & CD-II - Foundation Richmond & 8 & 1 \\
\hline 1 & 9 & 1 & Cool Season Crested - Evans (2004) & 9 & 1 \\
\hline 1 & 10 & 1 & NDAD 1 A.desertorum CWG & 10 & 1 \\
\hline 1 & 11 & 1 & NDAD 2 A.desertorum CWG & 11 & 1 \\
\hline 1 & 12 & 1 & NDAD 3 A.desertorum CWG & 12 & 1 \\
\hline 1 & 13 & 1 & Manchar Smooth Brome & 13 & 1 \\
\hline 1 & 14 & 1 & Smooth Bromegrass ( Bluecreek 04) & 14 & 1 \\
\hline 1 & 15 & 1 & San Luis - Slender WG & 15 & 1 \\
\hline 1 & 16 & 1 & Army Slender WG 02 & 16 & 1 \\
\hline 1 & 17 & 1 & Pryor - Slender WG & 17 & 1 \\
\hline 1 & 18 & 1 & Revenue Slender WG & 18 & 1 \\
\hline 1 & 19 & 1 & Rhizome Slender - Nephi 2005 & 19 & 1 \\
\hline 1 & 20 & 1 & Swift - RWR & 20 & 1 \\
\hline 1 & 21 & 1 & Bozoisky II & 21 & 1 \\
\hline 1 & 22 & 1 & Bozoisky RWR & 22 & 1 \\
\hline 1 & 23 & 1 & Diploid RWR - Nephi 2004 & 23 & 1 \\
\hline 1 & 24 & 1 & BozXTet RWR - Nephi 2004 & 24 & 1 \\
\hline 1 & 25 & 1 & Critana TWG & 25 & 1 \\
\hline 1 & 26 & 1 & Bannock TWG & 26 & 1 \\
\hline 1 & 27 & 1 & Exp. Blue Creek TWG & 27 & 1 \\
\hline 1 & 28 & 1 & Sodar TWG & 28 & 1 \\
\hline 1 & 29 & 1 & Schwendimar TWG & 29 & 1 \\
\hline 1 & 30 & 1 & Salina Wildrye - Lakeside 97 & 30 & 1 \\
\hline 1 & 31 & 1 & Salina Wildrye - Nephi 2005 & 31 & 1 \\
\hline 1 & 32 & 1 & $\mathrm{BC} 118$ & 63 & 2 \\
\hline 1 & 33 & 1 & Immigrant & 64 & 2 \\
\hline 1 & 34 & 1 & KZ6X Select & 65 & 2 \\
\hline
\end{tabular}




\begin{tabular}{|c|c|c|c|c|c|}
\hline Rep & Row & Range & Entry & Entry\# & Block \\
\hline 1 & 35 & 1 & Sahro & 66 & 2 \\
\hline 1 & 36 & 1 & Karnabchulsky & 67 & 2 \\
\hline 1 & 1 & 2 & Arriba WWG & 32 & 1 \\
\hline 1 & 2 & 2 & Barton WWG & 33 & 1 \\
\hline 1 & 3 & 2 & SB-3 WWG & 34 & 1 \\
\hline 1 & 4 & 2 & TC-3 WWG & 35 & 1 \\
\hline 1 & 5 & 2 & Rosana WWG & 36 & 1 \\
\hline 1 & 6 & 2 & Rodan WWG & 37 & 1 \\
\hline 1 & 7 & 2 & Expedition Snake River WG & 38 & 1 \\
\hline 1 & 8 & 2 & Secar Snake River WG & 39 & 1 \\
\hline 1 & 9 & 2 & Snake River BC 04 & 40 & 1 \\
\hline 1 & 10 & 2 & Snake River N - Nephi 2005 & 41 & 1 \\
\hline 1 & 11 & 2 & Pubescent Siberian WG & 42 & 1 \\
\hline 1 & 12 & 2 & Vavilov - Foundation North Logan 04 & 43 & 1 \\
\hline 1 & 13 & 2 & Vavilov Select - Blue Creek 04 & 44 & 1 \\
\hline 1 & 14 & 2 & Vavilov Select -Nephi 2005 & 45 & 1 \\
\hline 1 & 15 & 2 & Anatone BBWG & 46 & 1 \\
\hline 1 & 16 & 2 & Goldar BBWG & 47 & 1 \\
\hline 1 & 17 & 2 & Columbia BBWG & 48 & 1 \\
\hline 1 & 18 & 2 & P-19 BBWG & 49 & 1 \\
\hline 1 & 19 & 2 & P-7 BBWG & 50 & 1 \\
\hline 1 & 20 & 2 & Sand Hollow BBST & 51 & 1 \\
\hline 1 & 21 & 2 & Fish Creek BBST & 52 & 1 \\
\hline 1 & 22 & 2 & Toe Jam Creek BBST & 53 & 1 \\
\hline 1 & 23 & 2 & Trailhead BWR & 54 & 1 \\
\hline 1 & 24 & 2 & L-45 BWR & 55 & 1 \\
\hline 1 & 25 & 2 & L-46 BWR & 56 & 1 \\
\hline 1 & 26 & 2 & L-54 BWR (Lahontan) & 57 & 1 \\
\hline 1 & 27 & 2 & Basin WR - Army H Field 2004 & 58 & 1 \\
\hline 1 & 28 & 2 & Magnar BWR & 59 & 1 \\
\hline 1 & 29 & 2 & Nezpar IRG & 60 & 1 \\
\hline 1 & 30 & 2 & White River IRG 2003 & 61 & 1 \\
\hline 1 & 31 & 2 & Rimrock IRG & 62 & 1 \\
\hline 1 & 32 & 2 & Otavny & 68 & 2 \\
\hline 1 & 33 & 2 & Pustinny & 69 & 2 \\
\hline 1 & 34 & 2 & Yakima Yarrow & 70 & 2 \\
\hline 1 & 35 & 2 & Yarrow Check & 71 & 2 \\
\hline
\end{tabular}




\begin{tabular}{|c|c|c|c|c|c|}
\hline Rep & Row & Range & Entry & Entry\# & Block \\
\hline 1 & 36 & 2 & Filler & 72 & 2 \\
\hline 2 & 1 & 3 & San Luis - Slender WG & 15 & 1 \\
\hline 2 & 2 & 3 & Greenar Intermediate WG & 1 & 1 \\
\hline 2 & 3 & 3 & Vavilov - Foundation North Logan 04 & 43 & 1 \\
\hline 2 & 4 & 3 & Swift - RWR & 20 & 1 \\
\hline 2 & 5 & 3 & Vavilov Select - Blue Creek 04 & 44 & 1 \\
\hline 2 & 6 & 3 & Goldar BBWG & 47 & 1 \\
\hline 2 & 7 & 3 & Nezpar IRG & 60 & 1 \\
\hline 2 & 8 & 3 & CD-II - Foundation Richmond & 8 & 1 \\
\hline 2 & 9 & 3 & Fish Creek BBST & 52 & 1 \\
\hline 2 & 10 & 3 & Magnar BWR & 59 & 1 \\
\hline 2 & 11 & 3 & Expedition Snake River WG & 38 & 1 \\
\hline 2 & 12 & 3 & Smooth Bromegrass ( Bluecreek 04) & 14 & 1 \\
\hline 2 & 13 & 3 & Diploid RWR - Nephi 2004 & 23 & 1 \\
\hline 2 & 14 & 3 & Bozoisky II & 21 & 1 \\
\hline 2 & 15 & 3 & P-19 BBWG & 49 & 1 \\
\hline 2 & 16 & 3 & TC-3 WWG & 35 & 1 \\
\hline 2 & 17 & 3 & Bozoisky RWR & 22 & 1 \\
\hline 2 & 18 & 3 & Pubescent Siberian WG & 42 & 1 \\
\hline 2 & 19 & 3 & Sodar TWG & 28 & 1 \\
\hline 2 & 20 & 3 & Manchar Smooth Brome & 13 & 1 \\
\hline 2 & 21 & 3 & P-7 BBWG & 50 & 1 \\
\hline 2 & 22 & 3 & Army Slender WG 02 & 16 & 1 \\
\hline 2 & 23 & 3 & Snake River N - Nephi 2005 & 41 & 1 \\
\hline 2 & 24 & 3 & L-46 BWR & 56 & 1 \\
\hline 2 & 25 & 3 & Snake River BC 04 & 40 & 1 \\
\hline 2 & 26 & 3 & Sand Hollow BBST & 51 & 1 \\
\hline 2 & 27 & 3 & L-54 BWR (Lahontan) & 57 & 1 \\
\hline 2 & 28 & 3 & Anatone BBWG & 46 & 1 \\
\hline 2 & 29 & 3 & HxB28 - Nephi 2004 (bulk selected) & 7 & 1 \\
\hline 2 & 30 & 3 & Columbia BBWG & 48 & 1 \\
\hline 2 & 31 & 3 & BozXTet RWR - Nephi 2004 & 24 & 1 \\
\hline 2 & 32 & 3 & Yakima Yarrow & 70 & 2 \\
\hline 2 & 33 & 3 & Otavny & 68 & 2 \\
\hline 2 & 34 & 3 & KZ6X Select & 65 & 2 \\
\hline 2 & 35 & 3 & Sahro & 66 & 2 \\
\hline 2 & 36 & 3 & Yarrow Check & 71 & 2 \\
\hline
\end{tabular}




\begin{tabular}{|c|c|c|c|c|c|}
\hline Rep & Row & Range & Entry & Entry\# & Block \\
\hline 2 & 1 & 4 & Pryor - Slender WG & 17 & 1 \\
\hline 2 & 2 & 4 & Rodan WWG & 37 & 1 \\
\hline 2 & 3 & 4 & Hycrest - CWG & 5 & 1 \\
\hline 2 & 4 & 4 & Trailhead BWR & 54 & 1 \\
\hline 2 & 5 & 4 & Cool Season Crested - Evans (2004) & 9 & 1 \\
\hline 2 & 6 & 4 & Hycrest II - Foundation Richmond & 6 & 1 \\
\hline 2 & 7 & 4 & Salina Wildrye - Lakeside 97 & 30 & 1 \\
\hline 2 & 8 & 4 & NDAD 1 A.desertorum CWG & 10 & 1 \\
\hline 2 & 9 & 4 & Revenue Slender WG & 18 & 1 \\
\hline 2 & 10 & 4 & Al Intermediate WG & 3 & 1 \\
\hline 2 & 11 & 4 & NDAD 3 A.desertorum CWG & 12 & 1 \\
\hline 2 & 12 & 4 & Barton WWG & 33 & 1 \\
\hline 2 & 13 & 4 & White River IRG 2003 & 61 & 1 \\
\hline 2 & 14 & 4 & NDAD 2 A.desertorum CWG & 11 & 1 \\
\hline 2 & 15 & 4 & I 1871 Intermediate WG & 2 & 1 \\
\hline 2 & 16 & 4 & Bannock TWG & 26 & 1 \\
\hline 2 & 17 & 4 & Salina Wildrye - Nephi 2005 & 31 & 1 \\
\hline 2 & 18 & 4 & SB-3 WWG & 34 & 1 \\
\hline 2 & 19 & 4 & L-45 BWR & 55 & 1 \\
\hline 2 & 20 & 4 & Basin WR - Army H Field 2004 & 58 & 1 \\
\hline 2 & 21 & 4 & Toe Jam Creek BBST & 53 & 1 \\
\hline 2 & 22 & 4 & Rosana WWG & 36 & 1 \\
\hline 2 & 23 & 4 & Arriba WWG & 32 & 1 \\
\hline 2 & 24 & 4 & Critana TWG & 25 & 1 \\
\hline 2 & 25 & 4 & Nordan - CWG & 4 & 1 \\
\hline 2 & 26 & 4 & Schwendimar TWG & 29 & 1 \\
\hline 2 & 27 & 4 & Secar Snake River WG & 39 & 1 \\
\hline 2 & 28 & 4 & Rhizome Slender - Nephi 2005 & 19 & 1 \\
\hline 2 & 29 & 4 & Rimrock IRG & 62 & 1 \\
\hline 2 & 30 & 4 & Exp. Blue Creek TWG & 27 & 1 \\
\hline 2 & 31 & 4 & Vavilov Select -Nephi 2005 & 45 & 1 \\
\hline 2 & 32 & 4 & Karnabchulsky & 67 & 2 \\
\hline 2 & 33 & 4 & Filler & 72 & 2 \\
\hline 2 & 34 & 4 & Immigrant & 64 & 2 \\
\hline 2 & 35 & 4 & $\mathrm{BC} 118$ & 63 & 2 \\
\hline 2 & 36 & 4 & Pustinny & 69 & 2 \\
\hline 3 & 1 & 5 & Salina Wildrye - Lakeside 97 & 30 & 1 \\
\hline
\end{tabular}




\begin{tabular}{|c|c|c|c|c|c|}
\hline Rep & Row & Range & Entry & Entry\# & Block \\
\hline 3 & 2 & 5 & Arriba WWG & 32 & 1 \\
\hline 3 & 3 & 5 & Expedition Snake River WG & 38 & 1 \\
\hline 3 & 4 & 5 & San Luis - Slender WG & 15 & 1 \\
\hline 3 & 5 & 5 & Pryor - Slender WG & 17 & 1 \\
\hline 3 & 6 & 5 & Snake River BC 04 & 40 & 1 \\
\hline 3 & 7 & 5 & HxB28 - Nephi 2004 (bulk selected) & 7 & 1 \\
\hline 3 & 8 & 5 & Sodar TWG & 28 & 1 \\
\hline 3 & 9 & 5 & NDAD 1 A.desertorum CWG & 10 & 1 \\
\hline 3 & 10 & 5 & Swift - RWR & 20 & 1 \\
\hline 3 & 11 & 5 & Hycrest II - Foundation Richmond & 6 & 1 \\
\hline 3 & 12 & 5 & SB-3 WWG & 34 & 1 \\
\hline 3 & 13 & 5 & White River IRG 2003 & 61 & 1 \\
\hline 3 & 14 & 5 & Army Slender WG 02 & 16 & 1 \\
\hline 3 & 15 & 5 & Bozoisky RWR & 22 & 1 \\
\hline 3 & 16 & 5 & Revenue Slender WG & 18 & 1 \\
\hline 3 & 17 & 5 & Salina Wildrye - Nephi 2005 & 31 & 1 \\
\hline 3 & 18 & 5 & Cool Season Crested - Evans (2004) & 9 & 1 \\
\hline 3 & 19 & 5 & Trailhead BWR & 54 & 1 \\
\hline 3 & 20 & 5 & Manchar Smooth Brome & 13 & 1 \\
\hline 3 & 21 & 5 & Al Intermediate WG & 3 & 1 \\
\hline 3 & 22 & 5 & Anatone BBWG & 46 & 1 \\
\hline 3 & 23 & 5 & BozXTet RWR - Nephi 2004 & 24 & 1 \\
\hline 3 & 24 & 5 & P-19 BBWG & 49 & 1 \\
\hline 3 & 25 & 5 & Bozoisky II & 21 & 1 \\
\hline 3 & 26 & 5 & NDAD 2 A.desertorum CWG & 11 & 1 \\
\hline 3 & 27 & 5 & Basin WR - Army H Field 2004 & 58 & 1 \\
\hline 3 & 28 & 5 & Exp. Blue Creek TWG & 27 & 1 \\
\hline 3 & 29 & 5 & P-7 BBWG & 50 & 1 \\
\hline 3 & 30 & 5 & Bannock TWG & 26 & 1 \\
\hline 3 & 31 & 5 & Nezpar IRG & 60 & 1 \\
\hline 3 & 32 & 5 & Karnabchulsky & 67 & 2 \\
\hline 3 & 33 & 5 & Sahro & 66 & 2 \\
\hline 3 & 34 & 5 & Otavny & 68 & 2 \\
\hline 3 & 35 & 5 & $\mathrm{BC} 118$ & 63 & 2 \\
\hline 3 & 36 & 5 & Filler & 72 & 2 \\
\hline 3 & 1 & 6 & Vavilov Select - Blue Creek 04 & 44 & 1 \\
\hline 3 & 2 & 6 & Nordan - CWG & 4 & 1 \\
\hline
\end{tabular}




\begin{tabular}{|c|c|c|c|c|c|}
\hline Rep & Row & Range & Entry & Entry\# & Block \\
\hline 3 & 3 & 6 & Greenar Intermediate WG & 1 & 1 \\
\hline 3 & 4 & 6 & Fish Creek BBST & 52 & 1 \\
\hline 3 & 5 & 6 & Toe Jam Creek BBST & 53 & 1 \\
\hline 3 & 6 & 6 & L-54 BWR (Lahontan) & 57 & 1 \\
\hline 3 & 7 & 6 & Rodan WWG & 37 & 1 \\
\hline 3 & 8 & 6 & Hycrest - CWG & 5 & 1 \\
\hline 3 & 9 & 6 & CD-II - Foundation Richmond & 8 & 1 \\
\hline 3 & 10 & 6 & Magnar BWR & 59 & 1 \\
\hline 3 & 11 & 6 & L-45 BWR & 55 & 1 \\
\hline 3 & 12 & 6 & Barton WWG & 33 & 1 \\
\hline 3 & 13 & 6 & Rimrock IRG & 62 & 1 \\
\hline 3 & 14 & 6 & Snake River N - Nephi 2005 & 41 & 1 \\
\hline 3 & 15 & 6 & Critana TWG & 25 & 1 \\
\hline 3 & 16 & 6 & Vavilov Select -Nephi 2005 & 45 & 1 \\
\hline 3 & 17 & 6 & Sand Hollow BBST & 51 & 1 \\
\hline 3 & 18 & 6 & Pubescent Siberian WG & 42 & 1 \\
\hline 3 & 19 & 6 & Secar Snake River WG & 39 & 1 \\
\hline 3 & 20 & 6 & TC-3 WWG & 35 & 1 \\
\hline 3 & 21 & 6 & L-46 BWR & 56 & 1 \\
\hline 3 & 22 & 6 & Columbia BBWG & 48 & 1 \\
\hline 3 & 23 & 6 & Rosana WWG & 36 & 1 \\
\hline 3 & 24 & 6 & Smooth Bromegrass ( Bluecreek 04) & 14 & 1 \\
\hline 3 & 25 & 6 & I 1871 Intermediate WG & 2 & 1 \\
\hline 3 & 26 & 6 & Schwendimar TWG & 29 & 1 \\
\hline 3 & 27 & 6 & NDAD 3 A.desertorum CWG & 12 & 1 \\
\hline 3 & 28 & 6 & Vavilov - Foundation North Logan 04 & 43 & 1 \\
\hline 3 & 29 & 6 & Diploid RWR - Nephi 2004 & 23 & 1 \\
\hline 3 & 30 & 6 & Goldar BBWG & 47 & 1 \\
\hline 3 & 31 & 6 & Rhizome Slender - Nephi 2005 & 19 & 1 \\
\hline 3 & 32 & 6 & Pustinny & 69 & 2 \\
\hline 3 & 33 & 6 & Yakima Yarrow & 70 & 2 \\
\hline 3 & 34 & 6 & Immigrant & 64 & 2 \\
\hline 3 & 35 & 6 & Yarrow Check & 71 & 2 \\
\hline 3 & 36 & 6 & KZ6X Select & 65 & 2 \\
\hline 4 & 1 & 7 & SB-3 WWG & 34 & 1 \\
\hline 4 & 2 & 7 & Smooth Bromegrass ( Bluecreek 04) & 14 & 1 \\
\hline 4 & 3 & 7 & San Luis - Slender WG & 15 & 1 \\
\hline
\end{tabular}




\begin{tabular}{|c|c|c|c|c|c|}
\hline Rep & Row & Range & Entry & Entry\# & Block \\
\hline 4 & 4 & 7 & I 1871 Intermediate WG & 2 & 1 \\
\hline 4 & 5 & 7 & TC-3 WWG & 35 & 1 \\
\hline 4 & 6 & 7 & Barton WWG & 33 & 1 \\
\hline 4 & 7 & 7 & Anatone BBWG & 46 & 1 \\
\hline 4 & 8 & 7 & Revenue Slender WG & 18 & 1 \\
\hline 4 & 9 & 7 & Magnar BWR & 59 & 1 \\
\hline 4 & 10 & 7 & NDAD 2 A.desertorum CWG & 11 & 1 \\
\hline 4 & 11 & 7 & Snake River BC 04 & 40 & 1 \\
\hline 4 & 12 & 7 & Bannock TWG & 26 & 1 \\
\hline 4 & 13 & 7 & Goldar BBWG & 47 & 1 \\
\hline 4 & 14 & 7 & Critana TWG & 25 & 1 \\
\hline 4 & 15 & 7 & Vavilov Select - Blue Creek 04 & 44 & 1 \\
\hline 4 & 16 & 7 & Nordan - CWG & 4 & 1 \\
\hline 4 & 17 & 7 & NDAD 1 A.desertorum CWG & 10 & 1 \\
\hline 4 & 18 & 7 & Schwendimar TWG & 29 & 1 \\
\hline 4 & 19 & 7 & P-7 BBWG & 50 & 1 \\
\hline 4 & 20 & 7 & Basin WR - Army H Field 2004 & 58 & 1 \\
\hline 4 & 21 & 7 & Exp. Blue Creek TWG & 27 & 1 \\
\hline 4 & 22 & 7 & Salina Wildrye - Lakeside 97 & 30 & 1 \\
\hline 4 & 23 & 7 & Greenar Intermediate WG & 1 & 1 \\
\hline 4 & 24 & 7 & Rhizome Slender - Nephi 2005 & 19 & 1 \\
\hline 4 & 25 & 7 & Salina Wildrye - Nephi 2005 & 31 & 1 \\
\hline 4 & 26 & 7 & Sodar TWG & 28 & 1 \\
\hline 4 & 27 & 7 & L-54 BWR (Lahontan) & 57 & 1 \\
\hline 4 & 28 & 7 & Sand Hollow BBST & 51 & 1 \\
\hline 4 & 29 & 7 & Hycrest II - Foundation Richmond & 6 & 1 \\
\hline 4 & 30 & 7 & P-19 BBWG & 49 & 1 \\
\hline 4 & 31 & 7 & Pryor - Slender WG & 17 & 1 \\
\hline 4 & 32 & 7 & KZ6X Select & 65 & 2 \\
\hline 4 & 33 & 7 & Yarrow Check & 71 & 2 \\
\hline 4 & 34 & 7 & Karnabchulsky & 67 & 2 \\
\hline 4 & 35 & 7 & Pustinny & 69 & 2 \\
\hline 4 & 36 & 7 & Otavny & 68 & 2 \\
\hline 4 & 1 & 8 & White River IRG 2003 & 61 & 1 \\
\hline 4 & 2 & 8 & Bozoisky RWR & 22 & 1 \\
\hline 4 & 3 & 8 & Pubescent Siberian WG & 42 & 1 \\
\hline 4 & 4 & 8 & HxB28 - Nephi 2004 (bulk selected) & 7 & 1 \\
\hline
\end{tabular}




\begin{tabular}{|c|c|c|c|c|c|}
\hline Rep & Row & Range & Entry & Entry \# & Block \\
\hline 4 & 5 & 8 & Swift - RWR & 20 & 1 \\
\hline 4 & 6 & 8 & Cool Season Crested - Evans (2004) & 9 & 1 \\
\hline 4 & 7 & 8 & NDAD 3 A.desertorum CWG & 12 & 1 \\
\hline 4 & 8 & 8 & Manchar Smooth Brome & 13 & 1 \\
\hline 4 & 9 & 8 & Diploid RWR - Nephi 2004 & 23 & 1 \\
\hline 4 & 10 & 8 & Hycrest - CWG & 5 & 1 \\
\hline 4 & 11 & 8 & Fish Creek BBST & 52 & 1 \\
\hline 4 & 12 & 8 & Rimrock IRG & 62 & 1 \\
\hline 4 & 13 & 8 & Trailhead BWR & 54 & 1 \\
\hline 4 & 14 & 8 & Expedition Snake River WG & 38 & 1 \\
\hline 4 & 15 & 8 & BozXTet RWR - Nephi 2004 & 24 & 1 \\
\hline 4 & 16 & 8 & Vavilov Select -Nephi 2005 & 45 & 1 \\
\hline 4 & 17 & 8 & L-46 BWR & 56 & 1 \\
\hline 4 & 18 & 8 & Arriba WWG & 32 & 1 \\
\hline 4 & 19 & 8 & Army Slender WG 02 & 16 & 1 \\
\hline 4 & 20 & 8 & Columbia BBWG & 48 & 1 \\
\hline 4 & 21 & 8 & CD-II - Foundation Richmond & 8 & 1 \\
\hline 4 & 22 & 8 & Toe Jam Creek BBST & 53 & 1 \\
\hline 4 & 23 & 8 & Nezpar IRG & 60 & 1 \\
\hline 4 & 24 & 8 & L-45 BWR & 55 & 1 \\
\hline 4 & 25 & 8 & Rosana WWG & 36 & 1 \\
\hline 4 & 26 & 8 & Vavilov - Foundation North Logan 04 & 43 & 1 \\
\hline 4 & 27 & 8 & Snake River N - Nephi 2005 & 41 & 1 \\
\hline 4 & 28 & 8 & Rodan WWG & 37 & 1 \\
\hline 4 & 29 & 8 & Bozoisky II & 21 & 1 \\
\hline 4 & 30 & 8 & Secar Snake River WG & 39 & 1 \\
\hline 4 & 31 & 8 & Al Intermediate WG & 3 & 1 \\
\hline 4 & 32 & 8 & Sahro & 66 & 2 \\
\hline 4 & 33 & 8 & Immigrant & 64 & 2 \\
\hline 4 & 34 & 8 & BC 118 & 63 & 2 \\
\hline 4 & 35 & 8 & Filler & 72 & 2 \\
\hline 4 & 36 & 8 & Yakima Yarrow & 70 & 2 \\
\hline
\end{tabular}

\section{D.5 Yakima Training Center data (monocultures and mixtures)}

The following raw data from YTC Exit 11 gives values for monocultures and mixes (Table 42). For the 6-month establishment measurements taken on 
14 May 2003, we counted the number of gaps as the number of $6.35 \times 6.35$ $\mathrm{cm}$ ( $2.5 \times 2.5$ in.) squares without plants over a total of 48 squares over four subsamples for each entry.

Table 42. Yakima Training Center monocultures and mixes 6-month establishment on 14 May 2003 (48-grid frame with 6.35 x 6.35-cm squares).

\begin{tabular}{|c|c|c|c|c|c|c|c|}
\hline \multirow[b]{2}{*}{ Entries } & \multirow[b]{2}{*}{ Rep } & \multicolumn{4}{|c|}{$\begin{array}{l}\text { Subsamples of no. of empty } \\
\text { squares in a } 48 \text {-grid frame }\end{array}$} & \multirow{2}{*}{$\begin{array}{l}\text { \% estab- } \\
\text { lishment }\end{array}$} & \multirow{2}{*}{$\begin{array}{l}\text { Mean \% } \\
\text { estab- } \\
\text { lishment }\end{array}$} \\
\hline & & 1 & 2 & 3 & 4 & & \\
\hline $\begin{array}{l}\text { Bluebunch WG-SERDP } \\
\text { Select }\end{array}$ & 1 & 35 & 37 & 38 & 33 & 26 & \\
\hline $\begin{array}{l}\text { Bluebunch WG-SERDP } \\
\text { Select }\end{array}$ & 2 & 38 & 3 & 25 & 31 & 49 & \\
\hline $\begin{array}{l}\text { Bluebunch WG-SERDP } \\
\text { Select }\end{array}$ & 3 & 27 & 36 & 28 & 29 & 38 & \\
\hline $\begin{array}{l}\text { Bluebunch WG-SERDP } \\
\text { Select }\end{array}$ & 4 & 48 & 48 & 46 & 36 & 7 & 30 \\
\hline BozXTet RWR & 1 & 28 & 21 & 16 & 16 & 58 & \\
\hline BozXTet RWR & 2 & 33 & 38 & 33 & 11 & 40 & \\
\hline BozXTet RWR & 3 & 15 & 16 & 30 & 34 & 51 & \\
\hline BozXTet RWR & 4 & 35 & 26 & 26 & 32 & 38 & 46.75 \\
\hline Goldar BWG & 1 & 26 & 22 & 25 & 39 & 42 & \\
\hline Goldar BWG & 2 & 45 & 42 & 42 & 23 & 21 & \\
\hline Goldar BWG & 3 & 42 & 37 & 35 & 11 & 35 & \\
\hline Goldar BWG & 4 & 32 & 40 & 25 & 35 & 31 & 32.25 \\
\hline Mix-1-Introduced & 1 & 41 & 44 & 40 & 43 & 13 & \\
\hline Mix-1-Introduced & 2 & 11 & 24 & 34 & 1 & 64 & \\
\hline Mix-1-Introduced & 3 & 14 & 23 & 26 & 21 & 56 & \\
\hline Mix-1-Introduced & 4 & 39 & 26 & 29 & 17 & 42 & 43.75 \\
\hline Mix-2-Native & 1 & 30 & 37 & 33 & 32 & 31 & \\
\hline Mix-2-Native & 2 & 24 & 21 & 25 & 18 & 54 & \\
\hline Mix-2-Native & 3 & 19 & 27 & 39 & 13 & 49 & \\
\hline Mix-2-Native & 4 & 39 & 17 & 28 & 32 & 40 & 43.5 \\
\hline Pryor Slender WG & 1 & 35 & 26 & 29 & 23 & 41 & \\
\hline Pryor Slender WG & 2 & 25 & 9 & 13 & 34 & 58 & \\
\hline Pryor Slender WG & 3 & 23 & 34 & 22 & 26 & 45 & \\
\hline Pryor Slender WG & 4 & 13 & 40 & 16 & 21 & 53 & 49.25 \\
\hline Roadcrest CWG & 1 & 47 & 38 & 45 & 34 & 15 & \\
\hline
\end{tabular}




\begin{tabular}{|c|c|c|c|c|c|c|c|}
\hline \multirow[b]{2}{*}{ Entries } & \multirow[b]{2}{*}{ Rep } & \multicolumn{4}{|c|}{$\begin{array}{l}\text { Subsamples of no. of empty } \\
\text { squares in a 48-grid frame }\end{array}$} & \multirow{2}{*}{$\begin{array}{l}\% \text { estab- } \\
\text { lishment }\end{array}$} & \multirow{2}{*}{$\begin{array}{c}\text { Mean \% } \\
\text { estab- } \\
\text { lishment }\end{array}$} \\
\hline & & 1 & 2 & 3 & 4 & & \\
\hline Roadcrest CWG & 2 & 7 & 45 & 29 & 16 & 49 & \\
\hline Roadcrest CWG & 3 & 29 & 46 & 22 & 34 & 32 & \\
\hline Roadcrest CWG & 4 & 20 & 29 & 38 & 25 & 42 & 34.5 \\
\hline Rosana WWG & 1 & 39 & 34 & 23 & 33 & 33 & \\
\hline Rosana WWG & 2 & 35 & 7 & 25 & 18 & 56 & \\
\hline Rosana WWG & 3 & 23 & 28 & 39 & 15 & 45 & \\
\hline Rosana WWG & 4 & 34 & 44 & 33 & 35 & 24 & 39.5 \\
\hline Sandberg BG-Check & 1 & 48 & 47 & 48 & 48 & 1 & \\
\hline Sandberg BG-Check & 2 & 38 & 23 & 47 & 37 & 24 & \\
\hline Sandberg BG-Check & 3 & 48 & 47 & 48 & 44 & 3 & \\
\hline Sandberg BG-Check & 4 & 48 & 48 & 38 & 48 & 5 & 8.25 \\
\hline $\begin{array}{l}\text { Sandberg BG-SERDP } \\
\text { Select }\end{array}$ & 1 & 48 & 48 & 48 & 47 & 1 & \\
\hline $\begin{array}{l}\text { Sandberg BG-SERDP } \\
\text { Select }\end{array}$ & 2 & 48 & 48 & 48 & 47 & 1 & \\
\hline $\begin{array}{l}\text { Sandberg BG-SERDP } \\
\text { Select }\end{array}$ & 3 & 47 & 35 & 45 & 48 & 9 & \\
\hline $\begin{array}{l}\text { Sandberg BG-SERDP } \\
\text { Select }\end{array}$ & 4 & 46 & 48 & 41 & 42 & 8 & 4.75 \\
\hline Secar Snake River WG & 1 & 43 & 35 & 32 & 39 & 22 & \\
\hline Secar Snake River WG & 2 & 25 & 28 & 36 & 26 & 40 & \\
\hline Secar Snake River WG & 3 & 27 & 21 & 8 & 15 & 63 & \\
\hline Secar Snake River WG & 4 & 35 & 16 & 43 & 32 & 34 & 39.75 \\
\hline $\begin{array}{l}\text { Slender WG-SERDP } \\
\text { Select }\end{array}$ & 1 & 6 & 14 & 22 & 31 & 62 & \\
\hline $\begin{array}{l}\text { Slender WG-SERDP } \\
\text { Select }\end{array}$ & 2 & 1 & 5 & 15 & 5 & 86 & \\
\hline $\begin{array}{l}\text { Slender WG-SERDP } \\
\text { Select }\end{array}$ & 3 & 9 & 6 & 5 & 4 & 88 & \\
\hline $\begin{array}{l}\text { Slender WG-SERDP } \\
\text { Select }\end{array}$ & 4 & 1 & 6 & 7 & 4 & 91 & 81.75 \\
\hline $\begin{array}{l}\text { Snake River-SERDP } \\
\text { Select }\end{array}$ & 1 & 28 & 42 & 26 & 38 & 30 & \\
\hline $\begin{array}{l}\text { Snake River-SERDP } \\
\text { Select }\end{array}$ & 2 & 21 & 33 & 36 & 34 & 35 & \\
\hline $\begin{array}{l}\text { Snake River-SERDP } \\
\text { Select }\end{array}$ & 3 & 40 & 44 & 38 & 24 & 24 & \\
\hline
\end{tabular}




\begin{tabular}{|c|c|c|c|c|c|c|c|}
\hline \multirow[b]{2}{*}{ Entries } & \multirow[b]{2}{*}{ Rep } & \multicolumn{4}{|c|}{$\begin{array}{l}\text { Subsamples of no. of empty } \\
\text { squares in a 48-grid frame }\end{array}$} & \multirow{2}{*}{$\begin{array}{l}\% \text { estab- } \\
\text { lishment }\end{array}$} & \multirow{2}{*}{$\begin{array}{c}\text { Mean \% } \\
\text { estab- } \\
\text { lishment }\end{array}$} \\
\hline & & 1 & 2 & 3 & 4 & & \\
\hline $\begin{array}{l}\text { Snake River-SERDP } \\
\text { Select }\end{array}$ & 4 & 38 & 41 & 38 & 32 & 22 & 27.75 \\
\hline Syn-A RWR & 1 & 8 & 21 & 15 & 28 & 63 & \\
\hline Syn-A RWR & 2 & 12 & 9 & 17 & 14 & 73 & \\
\hline Syn-A RWR & 3 & 32 & 37 & 41 & 27 & 29 & \\
\hline Syn-A RWR & 4 & 18 & 29 & 32 & 17 & 50 & 53.75 \\
\hline Trailhead Basin WR & 1 & 42 & 45 & 31 & 37 & 19 & \\
\hline Trailhead Basin WR & 2 & 46 & 39 & 47 & 35 & 13 & \\
\hline Trailhead Basin WR & 3 & 27 & 39 & 31 & 27 & 35 & \\
\hline Trailhead Basin WR & 4 & 40 & 36 & 38 & 37 & 21 & 22 \\
\hline Vavilov Siberian WG & 1 & 42 & 45 & 29 & 44 & 17 & \\
\hline Vavilov Siberian WG & 2 & 45 & 35 & 32 & 26 & 28 & \\
\hline Vavilov Siberian WG & 3 & 41 & 40 & 46 & 39 & 14 & \\
\hline Vavilov Siberian WG & 4 & 19 & 31 & 36 & 43 & 33 & 23 \\
\hline $\begin{array}{l}\text { Vavilov-SERDP Select } \\
\text { Siberian WG }\end{array}$ & 1 & 21 & 31 & 17 & 45 & 41 & \\
\hline $\begin{array}{l}\text { Vavilov-SERDP Select } \\
\text { Siberian WG }\end{array}$ & 2 & 3 & 34 & 15 & 16 & 65 & \\
\hline $\begin{array}{l}\text { Vavilov-SERDP Select } \\
\text { Siberian WG }\end{array}$ & 3 & 23 & 22 & 34 & 44 & 36 & \\
\hline $\begin{array}{l}\text { Vavilov-SERDP Select } \\
\text { Siberian WG }\end{array}$ & 4 & 4 & 20 & 13 & 26 & 67 & 52.25 \\
\hline $\begin{array}{l}\text { Western WG-SERDP } \\
\text { Select }\end{array}$ & 1 & 15 & 18 & 12 & 27 & 63 & \\
\hline $\begin{array}{l}\text { Western WG-SERDP } \\
\text { Select }\end{array}$ & 2 & 14 & 6 & 4 & 17 & 79 & \\
\hline $\begin{array}{l}\text { Western WG-SERDP } \\
\text { Select }\end{array}$ & 3 & 13 & 15 & 14 & 12 & 72 & \\
\hline $\begin{array}{l}\text { Western WG-SERDP } \\
\text { Select }\end{array}$ & 4 & 10 & 14 & 6 & 12 & 78 & 73 \\
\hline Western Yarrow-Check & 1 & 42 & 48 & 47 & 43 & 6 & \\
\hline Western Yarrow-Check & 2 & 47 & 48 & 48 & 47 & 1 & \\
\hline Western Yarrow-Check & 3 & 48 & 47 & 48 & 46 & 2 & \\
\hline Western Yarrow-Check & 4 & 41 & 41 & 47 & 47 & 8 & 4.25 \\
\hline $\begin{array}{l}\text { Western Yarrow- } \\
\text { SERDP Select }\end{array}$ & 1 & 46 & 48 & 47 & 44 & 4 & \\
\hline
\end{tabular}




\begin{tabular}{|c|c|c|c|c|c|c|c|}
\hline \multirow[b]{2}{*}{ Entries } & \multirow[b]{2}{*}{ Rep } & \multicolumn{4}{|c|}{$\begin{array}{l}\text { Subsamples of no. of empty } \\
\text { squares in a 48-grid frame }\end{array}$} & \multirow{2}{*}{$\begin{array}{l}\% \text { estab- } \\
\text { lishment }\end{array}$} & \multirow{2}{*}{$\begin{array}{c}\text { Mean \% } \\
\text { estab- } \\
\text { lishment }\end{array}$} \\
\hline & & 1 & 2 & 3 & 4 & & \\
\hline $\begin{array}{l}\text { Western Yarrow- } \\
\text { SERDP Select }\end{array}$ & 2 & 47 & 48 & 48 & 48 & 1 & \\
\hline $\begin{array}{l}\text { Western Yarrow- } \\
\text { SERDP Select }\end{array}$ & 3 & 43 & 44 & 47 & 48 & 5 & \\
\hline $\begin{array}{l}\text { Western Yarrow- } \\
\text { SERDP Select }\end{array}$ & 4 & 48 & 45 & 42 & 47 & 5 & 3.75 \\
\hline
\end{tabular}

YTC data were taken 19 April 2004 and June 2005. This time, larger squares were measured: we counted the number of $12.7 \times 12.7-\mathrm{cm}$ ( $5 \times 5^{-}$ in.) squares out of 24 over three subsamples (Table 43 and Table 44).

Table 43. Yakima Training Center monocultures and mixes at 1.5 years on 19 April 2004 (24-grid frame with 12.7 x 12.7-cm squares).

\begin{tabular}{|c|c|c|c|c|c|c|c|c|}
\hline \multirow[b]{2}{*}{ Plot } & \multirow[b]{2}{*}{ Entry } & \multirow[b]{2}{*}{ Rep } & \multicolumn{3}{|c|}{$\begin{array}{l}\text { Subsamples of no. of empty } \\
\text { squares in a 24-grid frame }\end{array}$} & \multirow{2}{*}{$\begin{array}{l}\text { Percent } \\
\text { stand }\end{array}$} & \multirow{2}{*}{$\begin{array}{c}\text { Mean } \\
\text { gaps }\end{array}$} & \multirow{2}{*}{$\begin{array}{c}\text { Mean } \\
\text { percent } \\
\text { stand }\end{array}$} \\
\hline & & & 1 & 2 & 3 & & & \\
\hline 10 & BBWG-SERDP & 1 & 19 & 17 & 20 & 22 & & \\
\hline 16 & BBWG-SERDP & 2 & 13 & 4 & 10 & 63 & & \\
\hline 9 & BBWG-SERDP & 3 & 3 & 10 & 4 & 76 & & \\
\hline 11 & BBWG-SERDP & 4 & 21 & 18 & 15 & 25 & 13 & 47 \\
\hline 5 & BOZXTET & 1 & 10 & 5 & 1 & 78 & & \\
\hline 12 & BOZXTET & 2 & 11 & 20 & 16 & 35 & & \\
\hline 15 & BOZXTET & 3 & 2 & 6 & 10 & 75 & & \\
\hline 3 & BOZXTET & 4 & 10 & 15 & 11 & 50 & 10 & 60 \\
\hline 9 & GOLDAR & 1 & 17 & 11 & 18 & 36 & & \\
\hline 10 & GOLDAR & 2 & 11 & 16 & 16 & 40 & & \\
\hline 8 & GOLDAR & 3 & 5 & 11 & 16 & 56 & & \\
\hline 14 & GOLDAR & 4 & 20 & 16 & 18 & 25 & 15 & 39 \\
\hline 19 & MIX-1 & 1 & 18 & 21 & 22 & 15 & & \\
\hline 4 & MIX-1 & 2 & 1 & 5 & 1 & 90 & & \\
\hline 17 & MIX-1 & 3 & 7 & 8 & 7 & 69 & 10 & 58 \\
\hline 20 & MIX-2 & 1 & 17 & 20 & 10 & 35 & & \\
\hline 2 & MIX-2 & 2 & 8 & 5 & 5 & 75 & & \\
\hline 7 & MIX-2 & 3 & 13 & 8 & 4 & 65 & & \\
\hline
\end{tabular}




\begin{tabular}{|c|c|c|c|c|c|c|c|c|}
\hline \multirow[b]{2}{*}{ Plot } & \multirow[b]{2}{*}{ Entry } & \multirow[b]{2}{*}{ Rep } & \multicolumn{3}{|c|}{$\begin{array}{l}\text { Subsamples of no. of empty } \\
\text { squares in a } 24 \text {-grid frame }\end{array}$} & \multirow{2}{*}{$\begin{array}{l}\text { Percent } \\
\text { stand }\end{array}$} & \multirow{2}{*}{$\begin{array}{l}\text { Mean } \\
\text { gaps }\end{array}$} & \multirow{2}{*}{$\begin{array}{l}\text { Mean } \\
\text { percent } \\
\text { stand }\end{array}$} \\
\hline & & & 1 & 2 & 3 & & & \\
\hline 10 & MIX-2 & 4 & 9 & 6 & 15 & 58 & 10 & 58 \\
\hline 11 & PRYOR & 1 & 19 & 13 & 13 & 38 & & \\
\hline 20 & PRYOR & 2 & 5 & 6 & 12 & 68 & & \\
\hline 19 & $\begin{array}{l}\text { PRYOR } \\
\end{array}$ & 3 & 24 & 17 & 15 & 22 & & \\
\hline 16 & PRYOR & 4 & 6 & 10 & 11 & 63 & 13 & 48 \\
\hline 3 & ROADCREST & 1 & 21 & 13 & 16 & 31 & & \\
\hline 5 & ROADCREST & 2 & 2 & 11 & 2 & 79 & & \\
\hline 2 & ROADCREST & 3 & 11 & 2 & 6 & 74 & & \\
\hline 2 & ROADCREST & 4 & 20 & 15 & 8 & 40 & 11 & 56 \\
\hline 13 & ROSANA & 1 & 14 & 13 & 13 & 44 & & \\
\hline 17 & ROSANA & 2 & 3 & 7 & 3 & 82 & & \\
\hline 11 & ROSANA & 3 & 8 & 11 & 2 & 71 & & \\
\hline 19 & ROSANA & 4 & 20 & 19 & 22 & 15 & 11 & 53 \\
\hline 16 & SAND-SERDP & 1 & 24 & 24 & 24 & 0 & & \\
\hline 11 & SAND-SERDP & 2 & 24 & 24 & 24 & 0 & & \\
\hline 14 & SAND-SERDP & 3 & 24 & 24 & 24 & 0 & & \\
\hline 1 & SAND-SERDP & 4 & 20 & 24 & 20 & 11 & 23 & 3 \\
\hline 15 & SAND-CK & 1 & 24 & 24 & 24 & 0 & & \\
\hline 18 & SAND-CK & 2 & 11 & 17 & 16 & 39 & & \\
\hline 4 & SAND-CK & 3 & 23 & 24 & 23 & 3 & & \\
\hline 17 & SAND-CK & 4 & 24 & 21 & 24 & 4 & 21 & 12 \\
\hline 7 & SECAR & 1 & 14 & 16 & 12 & 42 & & \\
\hline 7 & SECAR & 2 & 4 & 6 & 7 & 76 & & \\
\hline 1 & SECAR & 3 & 2 & 4 & 8 & 81 & & \\
\hline 18 & SECAR & 4 & 21 & 16 & 12 & 32 & 10 & 58 \\
\hline 12 & SLEN-SERDP & 1 & 4 & 15 & 24 & 40 & & \\
\hline 6 & SLEN-SERDP & 2 & 3 & 4 & 4 & 85 & & \\
\hline 13 & SLEN-SERDP & 3 & 7 & 4 & 2 & 82 & 7 & 69 \\
\hline 8 & SRWG-SERDP & 1 & 20 & 15 & 19 & 25 & & \\
\hline 3 & SRWG-SERDP & 2 & 9 & 18 & 11 & 47 & & \\
\hline 10 & SRWG-SERDP & 3 & 11 & 3 & 17 & 57 & & \\
\hline 20 & SRWG-SERDP & 4 & 16 & 18 & 13 & 35 & 14 & 41 \\
\hline 4 & SYNA & 1 & 3 & 1 & 9 & 82 & & \\
\hline 8 & SYNA & 2 & 4 & 4 & 3 & 85 & & \\
\hline 20 & SYNA & 3 & 20 & 23 & 17 & 17 & & \\
\hline
\end{tabular}




\begin{tabular}{|c|c|c|c|c|c|c|c|c|}
\hline \multirow[b]{2}{*}{ Plot } & \multirow[b]{2}{*}{ Entry } & \multirow[b]{2}{*}{ Rep } & \multicolumn{3}{|c|}{$\begin{array}{l}\text { Subsamples of no. of empty } \\
\text { squares in a 24-grid frame }\end{array}$} & \multirow{2}{*}{$\begin{array}{l}\text { Percent } \\
\text { stand }\end{array}$} & \multirow{2}{*}{$\begin{array}{l}\text { Mean } \\
\text { gaps }\end{array}$} & \multirow{2}{*}{$\begin{array}{c}\text { Mean } \\
\text { percent } \\
\text { stand }\end{array}$} \\
\hline & & & 1 & 2 & 3 & & & \\
\hline 15 & SYNA & 4 & 7 & 3 & 2 & 83 & 8 & 67 \\
\hline 6 & TRAILHEAD & 1 & 21 & 18 & 20 & 18 & & \\
\hline 14 & TRAILHEAD & 2 & 23 & 21 & 21 & 10 & & \\
\hline 6 & TRAILHEAD & 3 & 6 & 15 & 8 & 60 & & \\
\hline 13 & TRAILHEAD & 4 & 14 & 14 & 12 & 44 & 16 & 33 \\
\hline 2 & VAV-SERDP & 1 & 13 & 18 & 13 & 39 & & \\
\hline 1 & VAV-SERDP & 2 & 4 & 2 & 2 & 89 & & \\
\hline 16 & VAV-SERDP & 3 & 9 & 18 & 12 & 46 & & \\
\hline 4 & VAV-SERDP & 4 & 6 & 3 & 7 & 78 & 9 & 63 \\
\hline 1 & VAVILOV & 1 & 20 & 17 & 22 & 18 & & \\
\hline 15 & VAVILOV & 2 & 17 & 9 & 19 & 38 & & \\
\hline 5 & VAVILOV & 3 & 16 & 16 & 17 & 32 & 17 & 29 \\
\hline 14 & WWG-SERDP & 1 & 11 & 4 & 8 & 68 & & \\
\hline 19 & WWG-SERDP & 2 & 1 & 1 & 3 & 93 & & \\
\hline 3 & WWG-SERDP & 3 & 4 & 3 & 7 & 81 & & \\
\hline 8 & WWG-SERDP & 4 & 6 & 5 & 3 & 81 & 5 & 81 \\
\hline 18 & WY-SERDP & 1 & 24 & 23 & 15 & 14 & & \\
\hline 9 & WY-SERDP & 2 & 24 & 22 & 22 & 6 & & \\
\hline 12 & WY-SERDP & 3 & 22 & 19 & 22 & 13 & & \\
\hline 9 & WY-SERDP & 4 & 23 & 20 & 22 & 10 & 22 & 11 \\
\hline 17 & WY-CK & 1 & 21 & 22 & 24 & 7 & & \\
\hline 13 & WY-CK & 2 & 23 & 24 & 22 & 4 & & \\
\hline 18 & WY-CK & 3 & 23 & 24 & 21 & 6 & & \\
\hline 12 & WY-CK & 4 & 20 & 22 & 24 & 8 & 23 & 6 \\
\hline
\end{tabular}


Table 44. Yakima Training Center monocultures and mixes at 2.5 years in June 2005 (24-grid frame with $12.7 \times 12.7-\mathrm{cm}$ squares).

\begin{tabular}{|c|c|c|c|c|c|c|c|c|c|}
\hline \multirow[b]{2}{*}{ Plot } & \multirow[b]{2}{*}{ Entry } & \multirow[b]{2}{*}{ Row } & \multicolumn{5}{|c|}{$\begin{array}{l}\text { Subsamples of no. of } \\
\text { empty squares in a } \\
\text { 24-grid frame }\end{array}$} & \multirow{2}{*}{$\begin{array}{l}\text { Percent } \\
\text { stand }\end{array}$} & \multirow{2}{*}{$\begin{array}{l}\text { Mean } \\
\text { percent } \\
\text { stand }\end{array}$} \\
\hline & & & 1 & 2 & 3 & 4 & 5 & & \\
\hline 10 & Bluebunch WG-SERDP Select & 1 & 12 & 20 & 16 & 12 & 4 & 47 & \\
\hline 16 & Bluebunch WG-SERDP Select & 2 & 21 & 11 & 4 & 13 & 12 & 49 & \\
\hline 9 & Bluebunch WG-SERDP Select & 3 & 3 & 3 & 5 & 1 & 8 & 83 & \\
\hline 11 & Bluebunch WG-SERDP Select & 4 & 21 & 24 & 23 & 18 & 19 & 13 & 48 \\
\hline 5 & BozXTet RWR & 1 & 2 & 6 & 7 & 7 & 0 & 82 & \\
\hline 12 & BozXTet RWR & 2 & 8 & 20 & 15 & 12 & 4 & 51 & \\
\hline 15 & BozXTet RWR & 3 & 5 & 11 & 9 & 0 & 0 & 79 & \\
\hline 3 & BozXTet RWR & 4 & 6 & 11 & 18 & 15 & 12 & 48 & 65 \\
\hline 9 & Goldar BWG & 1 & 9 & 22 & 18 & 9 & 14 & 40 & \\
\hline 10 & Goldar BWG & 2 & 17 & 19 & 23 & 11 & 8 & 35 & \\
\hline 8 & Goldar BWG & 3 & 7 & 2 & 12 & 17 & 19 & 53 & \\
\hline 14 & Goldar BWG & 4 & 21 & 12 & 13 & 22 & 13 & 33 & 40 \\
\hline 19 & Mix-1-Introduced & 1 & 7 & 24 & 20 & 18 & 7 & 37 & \\
\hline 4 & Mix-1-Introduced & 2 & 4 & 5 & 10 & 4 & 3 & 78 & \\
\hline 17 & Mix-1-Introduced & 3 & 3 & 5 & 12 & 6 & 6 & 73 & \\
\hline 5 & Mix-1-Introduced & 4 & 18 & 15 & 14 & 9 & 5 & 49 & 59 \\
\hline 20 & Mix-2-Native & 1 & 20 & 14 & 16 & 8 & 11 & 43 & \\
\hline 2 & Mix-2-Native & 2 & 9 & 12 & 5 & 10 & 6 & 65 & \\
\hline 7 & Mix-2-Native & 3 & 2 & 6 & 7 & 18 & 4 & 69 & \\
\hline 10 & Mix-2-Native & 4 & 8 & 15 & 9 & 11 & 12 & 54 & 58 \\
\hline 11 & Pryor Slender WG & 1 & 19 & 17 & 18 & 13 & 19 & 28 & \\
\hline 20 & Pryor Slender WG & 2 & 22 & 8 & 22 & 24 & 19 & 21 & \\
\hline 19 & Pryor Slender WG & 3 & 20 & 24 & 21 & 21 & 1 & 28 & \\
\hline 16 & Pryor Slender WG & 4 & 8 & 12 & 20 & 23 & 19 & 32 & 27 \\
\hline 3 & Roadcrest CWG & 1 & 22 & 19 & 14 & 17 & 11 & 31 & \\
\hline 5 & Roadcrest CWG & 2 & 0 & 3 & 17 & 5 & 0 & 79 & \\
\hline 2 & Roadcrest CWG & 3 & 7 & 9 & 2 & 11 & 10 & 68 & \\
\hline 2 & Roadcrest CWG & 4 & 7 & 10 & 20 & 12 & 3 & 57 & 59 \\
\hline
\end{tabular}




\begin{tabular}{|c|c|c|c|c|c|c|c|c|c|}
\hline \multirow[b]{2}{*}{ Plot } & \multirow[b]{2}{*}{ Entry } & \multirow[b]{2}{*}{ Row } & \multicolumn{5}{|c|}{$\begin{array}{l}\text { Subsamples of no. of } \\
\text { empty squares in a } \\
\text { 24-grid frame }\end{array}$} & \multirow{2}{*}{$\begin{array}{l}\text { Percent } \\
\text { stand }\end{array}$} & \multirow{2}{*}{$\begin{array}{l}\text { Mean } \\
\text { percent } \\
\text { stand }\end{array}$} \\
\hline & & & 1 & 2 & 3 & 4 & 5 & & \\
\hline 13 & Rosana WWG & 1 & 10 & 4 & 6 & 15 & 8 & 64 & \\
\hline 17 & Rosana WWG & 2 & 15 & 2 & 7 & 8 & 9 & 66 & \\
\hline 11 & Rosana WWG & 3 & 1 & 0 & 9 & 8 & 11 & 76 & \\
\hline 19 & Rosana WWG & 4 & 12 & 20 & 16 & 14 & 17 & 34 & 60 \\
\hline 15 & Sandberg BG-Check & 1 & 24 & 24 & 24 & 24 & 24 & 0 & \\
\hline 18 & Sandberg BG-Check & 2 & 24 & 12 & 19 & 21 & 18 & 22 & \\
\hline 4 & Sandberg BG-Check & 3 & 21 & 24 & 22 & 24 & 24 & 4 & \\
\hline 17 & Sandberg BG-Check & 4 & 22 & 21 & 21 & 24 & 24 & 7 & 8 \\
\hline 16 & Sandberg BG-SERDP Select & 1 & 21 & 24 & 24 & 23 & 24 & 3 & \\
\hline 11 & Sandberg BG-SERDP Select & 2 & 22 & 23 & 24 & 24 & 24 & 3 & \\
\hline 14 & Sandberg BG-SERDP Select & 3 & 22 & 23 & 24 & 19 & 24 & 7 & \\
\hline 1 & Sandberg BG-SERDP Select & 4 & 17 & 23 & 24 & 13 & 22 & 18 & 8 \\
\hline 7 & Secar Snake River WG & 1 & 17 & 15 & 19 & 12 & 14 & 36 & \\
\hline 7 & Secar Snake River WG & 2 & 12 & 2 & 13 & 7 & 3 & 69 & \\
\hline 1 & Secar Snake River WG & 3 & 10 & 2 & 5 & 3 & 7 & 78 & \\
\hline 18 & Secar Snake River WG & 4 & 14 & 10 & 15 & 22 & 15 & 37 & 55 \\
\hline 12 & Slender WG-SERDP Select & 1 & 24 & 23 & 22 & 14 & 24 & 11 & \\
\hline 6 & Slender WG-SERDP Select & 2 & 24 & 12 & 17 & 17 & 12 & 32 & \\
\hline 13 & Slender WG-SERDP Select & 3 & 19 & 23 & 24 & 22 & 12 & 17 & \\
\hline 7 & Slender WG-SERDP Select & 4 & 11 & 16 & 21 & 24 & 22 & 22 & 20 \\
\hline 8 & Snake River-SERDP Select & 1 & 13 & 16 & 10 & 12 & 5 & 53 & \\
\hline 3 & Snake River-SERDP Select & 2 & 5 & 9 & 20 & 15 & 10 & 51 & \\
\hline 10 & Snake River-SERDP Select & 3 & 0 & 2 & 3 & 21 & 6 & 73 & \\
\hline 20 & Snake River-SERDP Select & 4 & 14 & 16 & 16 & 18 & 9 & 39 & 54 \\
\hline 4 & Syn-A RWR & 1 & 6 & 2 & 5 & 2 & 2 & 86 & \\
\hline 8 & Syn-A RWR & 2 & 4 & 0 & 6 & 3 & 1 & 88 & \\
\hline 20 & Syn-A RWR & 3 & 13 & 15 & 17 & 17 & 1 & 48 & \\
\hline 15 & Syn-A RWR & 4 & 6 & 6 & 6 & 10 & 7 & 71 & 73 \\
\hline 6 & Trailhead Basin WR & 1 & 8 & 13 & 21 & 21 & 22 & 29 & \\
\hline
\end{tabular}




\begin{tabular}{|c|c|c|c|c|c|c|c|c|c|}
\hline \multirow[b]{2}{*}{ Plot } & \multirow[b]{2}{*}{ Entry } & \multirow[b]{2}{*}{ Row } & \multicolumn{5}{|c|}{$\begin{array}{l}\text { Subsamples of no. of } \\
\text { empty squares in a } \\
\text { 24-grid frame }\end{array}$} & \multirow{2}{*}{$\begin{array}{l}\text { Percent } \\
\text { stand }\end{array}$} & \multirow{2}{*}{$\begin{array}{l}\text { Mean } \\
\text { percent } \\
\text { stand }\end{array}$} \\
\hline & & & 1 & 2 & 3 & 4 & 5 & & \\
\hline 14 & Trailhead Basin WR & 2 & 24 & 24 & 21 & 23 & 16 & 10 & \\
\hline 6 & Trailhead Basin WR & 3 & 6 & 17 & 9 & 16 & 12 & 50 & \\
\hline 13 & Trailhead Basin WR & 4 & 13 & 18 & 14 & 18 & 13 & 37 & 31 \\
\hline 1 & Vavilov Siberian WG & 1 & 16 & 16 & 8 & 13 & 9 & 48 & \\
\hline 15 & Vavilov Siberian WG & 2 & 17 & 16 & 8 & 9 & 5 & 54 & \\
\hline 5 & Vavilov Siberian WG & 3 & 10 & 8 & 10 & 20 & 20 & 43 & \\
\hline 6 & Vavilov Siberian WG & 4 & 12 & 12 & 7 & 8 & 6 & 63 & 52 \\
\hline 2 & $\begin{array}{l}\text { Vavilov-SERDP Select Siberian } \\
\text { WG }\end{array}$ & 1 & 16 & 3 & 12 & 6 & 6 & 64 & \\
\hline 1 & $\begin{array}{l}\text { Vavilov-SERDP Select Siberian } \\
\text { WG }\end{array}$ & 2 & 3 & 13 & 4 & 4 & 2 & 78 & \\
\hline 16 & $\begin{array}{l}\text { Vavilov-SERDP Select Siberian } \\
\text { WG }\end{array}$ & 3 & 8 & 3 & 4 & 9 & 9 & 73 & \\
\hline 4 & $\begin{array}{l}\text { Vavilov-SERDP Select Siberian } \\
\text { WG }\end{array}$ & 4 & 8 & 7 & 2 & 5 & 9 & 74 & 72 \\
\hline 14 & Western WG-SERDP Select & 1 & 5 & 7 & 3 & 11 & 3 & 76 & \\
\hline 19 & Western WG-SERDP Select & 2 & 5 & 2 & 4 & 7 & 4 & 82 & \\
\hline 3 & Western WG-SERDP Select & 3 & 0 & 3 & 7 & 1 & 3 & 88 & \\
\hline 8 & Western WG-SERDP Select & 4 & 4 & 3 & 7 & 7 & 8 & 76 & 80 \\
\hline 17 & Western Yarrow-Check & 1 & 21 & 24 & 16 & 23 & 19 & 14 & \\
\hline 13 & Western Yarrow-Check & 2 & 21 & 24 & 23 & 24 & 22 & 5 & \\
\hline 18 & Western Yarrow-Check & 3 & 24 & 23 & 24 & 22 & 22 & 4 & \\
\hline 12 & Western Yarrow-Check & 4 & 24 & 23 & 22 & 22 & 21 & 7 & 8 \\
\hline 18 & Western Yarrow-SERDP Select & 1 & 24 & 23 & 23 & 23 & 15 & 10 & \\
\hline 9 & Western Yarrow-SERDP Select & 2 & 23 & 22 & 24 & 24 & 21 & 5 & \\
\hline 12 & Western Yarrow-SERDP Select & 3 & 18 & 19 & 17 & 17 & 18 & 26 & \\
\hline 9 & Western Yarrow-SERDP Select & 4 & 24 & 22 & 14 & 23 & 22 & 13 & 13 \\
\hline
\end{tabular}




\section{D.6 Camp Guernsey data (monocultures and mixtures)}

The Guernsey River site was planted 31 March 2004 (Table 45).

Establishment data were taken 2 months later on 2 June 2004 (Table 46); percent coverage data were taken in June over the next 2 years (Table 47).

Table 45. Guernsey River site establishment of monocultures and mixtures; data taken June 2, 2004 using three sub-samples in each replication (48-grid frame with $6.35 \times 6.35$-cm squares).

\begin{tabular}{|c|c|c|c|c|c|c|c|}
\hline Entry & Row & $\operatorname{Rep}$ & $\begin{array}{l}\text { No. of } \\
\text { squares } \\
\text { missing } \\
\text { plants } \\
\text { (out of } \\
48 \text { ) }\end{array}$ & $\begin{array}{l}\text { No. of } \\
\text { squares } \\
\text { missing } \\
\text { plants } \\
\text { (out of } \\
48 \text { ) }\end{array}$ & $\begin{array}{l}\text { No. of } \\
\text { squares } \\
\text { missing } \\
\text { plants } \\
\text { (out of } \\
48 \text { ) }\end{array}$ & Mean & $\begin{array}{l}\text { Mean } \\
\text { of reps }\end{array}$ \\
\hline Al Intermediate WG & 25 & 1 & 12 & 16 & 25 & 18 & \\
\hline Al Intermediate WG & 5 & 2 & 21 & 27 & 33 & 27 & \\
\hline Al Intermediate WG & 9 & 3 & 23 & 31 & 34 & 29 & 25 \\
\hline Bannock Thickspike WG & 29 & 1 & 18 & 26 & 27 & 24 & \\
\hline Bannock Thickspike WG & 8 & 2 & 9 & 17 & 15 & 14 & \\
\hline Bannock Thickspike WG & 5 & 3 & 28 & 34 & 43 & 35 & 24 \\
\hline Bozoisky RWR & 2 & 1 & 26 & 48 & 46 & 40 & \\
\hline Bozoisky RWR & 10 & 2 & 34 & 42 & 42 & 39 & \\
\hline Bozoisky RWR & 4 & 3 & 36 & 37 & 46 & 40 & 40 \\
\hline Bozoisky X Tetra RWR & 1 & 1 & 22 & 22 & 15 & 20 & \\
\hline Bozoisky X Tetra RWR & 28 & 2 & 7 & 20 & 23 & 17 & \\
\hline Bozoisky X Tetra RWR & 12 & 3 & 20 & 17 & 29 & 22 & 19 \\
\hline Camper Little Bluestem & 31 & 1 & 45 & 47 & 44 & 45 & \\
\hline Camper Little Bluestem & 34 & 2 & 45 & 47 & 44 & 45 & \\
\hline Camper Little Bluestem & 24 & 3 & 48 & 48 & 47 & 48 & 46 \\
\hline Flintlock Western WG & 15 & 1 & 24 & 21 & 16 & 20 & \\
\hline Flintlock Western WG & 32 & 2 & 22 & 19 & 13 & 18 & \\
\hline Flintlock Western WG & 19 & 3 & 18 & 27 & 27 & 24 & 21 \\
\hline Goldar Bluebunch WG & 11 & 1 & 17 & 35 & 40 & 31 & \\
\hline Goldar Bluebunch WG & 31 & 2 & 35 & 30 & 30 & 32 & \\
\hline Goldar Bluebunch WG & 23 & 3 & 9 & 14 & 17 & 13 & 25 \\
\hline Kazak Pub. Siberian WG & 8 & 1 & 31 & 23 & 29 & 28 & \\
\hline Kazak Pub. Siberian WG & 20 & 2 & 23 & 20 & 30 & 24 & \\
\hline Kazak Pub. Siberian WG & 14 & 3 & 21 & 19 & 35 & 25 & 26 \\
\hline Lovington Blue Grama & 27 & 1 & 47 & 47 & 43 & 46 & \\
\hline Lovington Blue Grama & 25 & 2 & 48 & 48 & 48 & 48 & \\
\hline Lovington Blue Grama & 30 & 3 & 48 & 47 & 47 & 47 & 47 \\
\hline
\end{tabular}




\begin{tabular}{|c|c|c|c|c|c|c|c|}
\hline Entry & Row & Rep & $\begin{array}{l}\text { No. of } \\
\text { squares } \\
\text { missing } \\
\text { plants } \\
\text { (out of } \\
48 \text { ) }\end{array}$ & $\begin{array}{l}\text { No. of } \\
\text { squares } \\
\text { missing } \\
\text { plants } \\
\text { (out of } \\
48 \text { ) }\end{array}$ & $\begin{array}{l}\text { No. of } \\
\text { squares } \\
\text { missing } \\
\text { plants } \\
\text { (out of } \\
48 \text { ) }\end{array}$ & Mean & $\begin{array}{l}\text { Mean } \\
\text { of reps }\end{array}$ \\
\hline Mix 1 - Introduced & 23 & 1 & 9 & 28 & 27 & 21 & \\
\hline Mix 1 - Introduced & 6 & 2 & 29 & 36 & 19 & 28 & \\
\hline Mix 1 - Introduced & 11 & 3 & 36 & 36 & 32 & 35 & 28 \\
\hline Mix 2 - Native & 24 & 1 & 14 & 20 & 16 & 17 & \\
\hline Mix 2 - Native & 17 & 2 & 22 & 28 & 32 & 27 & \\
\hline Mix 2 - Native & 25 & 3 & 20 & 29 & 31 & 27 & 24 \\
\hline Mix 3 - Guernsey & 26 & 1 & 41 & 39 & 35 & 38 & \\
\hline Mix 3 - Guernsey & 27 & 2 & 38 & 41 & 40 & 40 & \\
\hline Mix 3 - Guernsey & 6 & 3 & 39 & 46 & 44 & 43 & 40 \\
\hline Mix 4 - core native & 28 & 1 & 33 & 25 & 21 & 26 & \\
\hline Mix 4 - core native & 21 & 2 & 28 & 25 & 21 & 25 & \\
\hline Mix 4 - core native & 32 & 3 & 19 & 16 & 6 & 14 & 22 \\
\hline Mix 5 - core + Al IWG & 30 & 1 & 20 & 33 & 29 & 27 & \\
\hline Mix 5 - core + Al IWG & 33 & 2 & 11 & 17 & 27 & 18 & \\
\hline Mix 5 - core + Al IWG & 22 & 3 & 23 & 29 & 10 & 21 & 22 \\
\hline $\begin{array}{l}\text { Mix } 6 \text { - core + SERDP } \\
\text { Sib.WG }\end{array}$ & 32 & 1 & 15 & 25 & 19 & 20 & \\
\hline $\begin{array}{l}\text { Mix } 6 \text { - core + SERDP } \\
\text { Sib.WG }\end{array}$ & 2 & 2 & 21 & 29 & 24 & 25 & \\
\hline $\begin{array}{l}\text { Mix } 6 \text { - core + SERDP } \\
\text { Sib.WG }\end{array}$ & 29 & 3 & 10 & 18 & 19 & 16 & 20 \\
\hline $\begin{array}{l}\text { Mix } 7 \text { - core + SERDP } \\
\text { RWR }\end{array}$ & 34 & 1 & 14 & 22 & 17 & 18 & \\
\hline $\begin{array}{l}\text { Mix } 7 \text { - core + SERDP } \\
\text { RWR }\end{array}$ & 26 & 2 & 22 & 29 & 18 & 23 & \\
\hline $\begin{array}{l}\text { Mix } 7 \text { - core + SERDP } \\
\text { RWR }\end{array}$ & 17 & 3 & 6 & 23 & 35 & 21 & 21 \\
\hline P-7 Bluebunch WG & 12 & 1 & 37 & 36 & 30 & 34 & \\
\hline P-7 Bluebunch WG & 15 & 2 & 31 & 21 & 24 & 25 & \\
\hline P-7 Bluebunch WG & 20 & 3 & 22 & 19 & 25 & 22 & 27 \\
\hline Pryor Slender WG & 4 & 1 & 30 & 32 & 24 & 29 & \\
\hline Pryor Slender WG & 24 & 2 & 22 & 27 & 29 & 26 & \\
\hline Pryor Slender WG & 1 & 3 & 37 & 43 & 36 & 39 & 31 \\
\hline Roadcrest Crested WG & 7 & 1 & 47 & 47 & 48 & 47 & \\
\hline Roadcrest Crested WG & 14 & 2 & 48 & 47 & 46 & 47 & \\
\hline
\end{tabular}




\begin{tabular}{|c|c|c|c|c|c|c|c|}
\hline Entry & Row & Rep & $\begin{array}{l}\text { No. of } \\
\text { squares } \\
\text { missing } \\
\text { plants } \\
\text { (out of } \\
48 \text { ) }\end{array}$ & $\begin{array}{l}\text { No. of } \\
\text { squares } \\
\text { missing } \\
\text { plants } \\
\text { (out of } \\
48 \text { ) }\end{array}$ & $\begin{array}{l}\text { No. of } \\
\text { squares } \\
\text { missing } \\
\text { plants } \\
\text { (out of } \\
48 \text { ) }\end{array}$ & Mean & $\begin{array}{l}\text { Mean } \\
\text { of reps }\end{array}$ \\
\hline Roadcrest Crested WG & 21 & 3 & 45 & 40 & 42 & 42 & 46 \\
\hline Rosana Western WG & 17 & 1 & 11 & 16 & 27 & 18 & \\
\hline Rosana Western WG & 19 & 2 & 35 & 26 & 24 & 28 & \\
\hline Rosana Western WG & 18 & 3 & 13 & 28 & 15 & 19 & 22 \\
\hline SB-2 Western WG & 16 & 1 & 24 & 28 & 28 & 27 & \\
\hline SB-2 Western WG & 22 & 2 & 11 & 11 & 14 & 12 & \\
\hline SB-2 Western WG & 7 & 3 & 25 & 25 & 32 & 27 & 22 \\
\hline Secar Snake River WG & 13 & 1 & 47 & 48 & 43 & 46 & \\
\hline Secar Snake River WG & 18 & 2 & 48 & 48 & 47 & 48 & \\
\hline Secar Snake River WG & 26 & 3 & 31 & 47 & 48 & 42 & 45 \\
\hline SERDP Basin WR & 20 & 1 & 36 & 41 & 39 & 39 & \\
\hline SERDP Basin WR & 23 & 2 & 48 & 31 & 48 & 42 & \\
\hline SERDP Basin WR & 3 & 3 & 48 & 47 & 47 & 47 & 43 \\
\hline SERDP Slender WG & 5 & 1 & 14 & 17 & 5 & 12 & \\
\hline SERDP Slender WG & 12 & 2 & 7 & 12 & 8 & 9 & \\
\hline SERDP Slender WG & 34 & 3 & 4 & 10 & 6 & 7 & 9 \\
\hline SERDP Slender WG - Rhiz. & 6 & 1 & 23 & 18 & 32 & 24 & \\
\hline SERDP Slender WG - Rhiz. & 3 & 2 & 36 & 34 & 44 & 38 & \\
\hline SERDP Slender WG - Rhiz. & 15 & 3 & 35 & 24 & 25 & 28 & 30 \\
\hline SERDP Snake River WG & 14 & 1 & 48 & 48 & 42 & 46 & \\
\hline SERDP Snake River WG & 9 & 2 & 39 & 46 & 45 & 43 & \\
\hline SERDP Snake River WG & 2 & 3 & 47 & 48 & 47 & 47 & 46 \\
\hline SERDP Syn A RWR & 3 & 1 & 31 & 41 & 32 & 35 & \\
\hline SERDP Syn A RWR & 11 & 2 & 28 & 25 & 23 & 25 & \\
\hline SERDP Syn A RWR & 33 & 3 & 13 & 18 & 12 & 14 & 25 \\
\hline SERDP TC-2 Western WG & 18 & 1 & 15 & 10 & 14 & 13 & \\
\hline SERDP TC-2 Western WG & 7 & 2 & 19 & 19 & 20 & 19 & \\
\hline SERDP TC-2 Western WG & 13 & 3 & 27 & 35 & 10 & 24 & 19 \\
\hline $\begin{array}{l}\text { SERDP Vavilov Siberian } \\
\text { WG }\end{array}$ & 10 & 1 & 15 & 15 & 19 & 16 & \\
\hline $\begin{array}{l}\text { SERDP Vavilov Siberian } \\
\text { WG }\end{array}$ & 13 & 2 & 34 & 25 & 24 & 28 & \\
\hline $\begin{array}{l}\text { SERDP Vavilov Siberian } \\
\text { WG }\end{array}$ & 16 & 3 & 7 & 32 & 27 & 22 & 22 \\
\hline SERDP Western Yarrow & 22 & 1 & 48 & 48 & 48 & 48 & \\
\hline
\end{tabular}




\begin{tabular}{|c|c|c|c|c|c|c|c|}
\hline Entry & Row & Rep & $\begin{array}{l}\text { No. of } \\
\text { squares } \\
\text { missing } \\
\text { plants } \\
\text { (out of } \\
48 \text { ) }\end{array}$ & $\begin{array}{l}\text { No. of } \\
\text { squares } \\
\text { missing } \\
\text { plants } \\
\text { (out of } \\
48 \text { ) }\end{array}$ & $\begin{array}{l}\text { No. of } \\
\text { squares } \\
\text { missing } \\
\text { plants } \\
\text { (out of } \\
48 \text { ) }\end{array}$ & Mean & $\begin{array}{l}\text { Mean } \\
\text { of reps }\end{array}$ \\
\hline SERDP Western Yarrow & 4 & 2 & 48 & 48 & 48 & 48 & \\
\hline SERDP Western Yarrow & 28 & 3 & 48 & 48 & 48 & 48 & 48 \\
\hline Texoka Buffalo Grass & 33 & 1 & 27 & 19 & 20 & 22 & \\
\hline Texoka Buffalo Grass & 30 & 2 & 16 & 31 & 32 & 26 & \\
\hline Texoka Buffalo Grass & 31 & 3 & 31 & 30 & 35 & 32 & 27 \\
\hline Trailhead Basin WR & 19 & 1 & 37 & 43 & 41 & 40 & \\
\hline Trailhead Basin WR & 29 & 2 & 45 & 44 & 41 & 43 & \\
\hline Trailhead Basin WR & 27 & 3 & 31 & 46 & 46 & 41 & 42 \\
\hline Vavilov Siberian WG & 9 & 1 & 32 & 28 & 32 & 31 & \\
\hline Vavilov Siberian WG & 16 & 2 & 23 & 22 & 25 & 23 & \\
\hline Vavilov Siberian WG & 8 & 3 & 35 & 36 & 36 & 36 & 30 \\
\hline Western Yarrow Check & 21 & 1 & 48 & 48 & 48 & 48 & \\
\hline Western Yarrow Check & 1 & 2 & 48 & 48 & 48 & 48 & \\
\hline Western Yarrow Check & 10 & 3 & 48 & 48 & 48 & 48 & 48 \\
\hline
\end{tabular}

Table 46. Guernsey River site, 1-year percent stand and weed data taken 2 June 2005 (24-grid frame; 12.7-x 12.7-cm squares).

\begin{tabular}{|c|c|c|c|c|c|c|c|}
\hline Entry & Row & Rep & $\begin{array}{l}\text { Number } \\
\text { of } 24 \\
\text { squares } \\
\text { without } \\
\text { plants }\end{array}$ & $\begin{array}{l}\text { Number } \\
\text { of } 24 \\
\text { squares } \\
\text { without } \\
\text { plants }\end{array}$ & $\begin{array}{l}\text { Number } \\
\text { of } 24 \\
\text { squares } \\
\text { without } \\
\text { plants }\end{array}$ & $\begin{array}{l}\text { Percent } \\
\text { stand }\end{array}$ & $\begin{array}{l}\% \text { Weeds } \\
\text { in plots } \\
\text { (visual } \\
\text { est.) }\end{array}$ \\
\hline Bozoisky X Tetra RWR & 1 & 1 & 9 & 15 & 14 & 47 & 70 \\
\hline Bozoisky RWR & 2 & 1 & 14 & 24 & 21 & 18 & 85 \\
\hline SERDP Syn A RWR & 3 & 1 & 16 & 20 & 22 & 19 & 70 \\
\hline Pryor Slender WG & 4 & 1 & 20 & 17 & 16 & 26 & 75 \\
\hline SERDP Slender WG & 5 & 1 & 9 & 12 & 12 & 54 & 20 \\
\hline SERDP Slender WG - Rhiz. & 6 & 1 & 23 & 23 & 23 & 4 & 65 \\
\hline Roadcrest Crested WG & 7 & 1 & 22 & 24 & 24 & 3 & 75 \\
\hline Kazak Pub. Siberian WG & 8 & 1 & 6 & 13 & 9 & 61 & 30 \\
\hline Vavilov Siberian WG & 9 & 1 & 13 & 10 & 12 & 51 & 5 \\
\hline SERDP Vavilov Siberian WG & 10 & 1 & 7 & 8 & 13 & 61 & 0 \\
\hline Goldar Bluebunch WG & 11 & 1 & 22 & 20 & 24 & 8 & 40 \\
\hline P-7 Bluebunch WG & 12 & 1 & 16 & 13 & 20 & 32 & 60 \\
\hline
\end{tabular}




\begin{tabular}{|c|c|c|c|c|c|c|c|}
\hline Entry & Row & Rep & $\begin{array}{l}\text { Number } \\
\text { of } 24 \\
\text { squares } \\
\text { without } \\
\text { plants }\end{array}$ & $\begin{array}{l}\text { Number } \\
\text { of } 24 \\
\text { squares } \\
\text { without } \\
\text { plants }\end{array}$ & $\begin{array}{l}\text { Number } \\
\text { of } 24 \\
\text { squares } \\
\text { without } \\
\text { plants }\end{array}$ & $\begin{array}{l}\text { Percent } \\
\text { stand }\end{array}$ & $\begin{array}{l}\% \text { Weeds } \\
\text { in plots } \\
\text { (visual } \\
\text { est.) }\end{array}$ \\
\hline Secar Snake River WG & 13 & 1 & 24 & 23 & 23 & 3 & 70 \\
\hline SERDP Snake River WG & 14 & 1 & 14 & 24 & 20 & 19 & 70 \\
\hline Flintlock Western WG & 15 & 1 & 23 & 21 & 13 & 21 & 70 \\
\hline SB-2 Western WG & 16 & 1 & 10 & 15 & 23 & 33 & 50 \\
\hline Rosana Western WG & 17 & 1 & 5 & 10 & 6 & 71 & 30 \\
\hline SERDP TC-2 Western WG & 18 & 1 & 7 & 1 & 4 & 83 & 20 \\
\hline Trailhead Basin WR & 19 & 1 & 19 & 22 & 20 & 15 & 70 \\
\hline SERDP Basin WR & 20 & 1 & 14 & 21 & 21 & 22 & 70 \\
\hline Western Yarrow Check & 21 & 1 & 24 & 24 & 24 & 0 & 80 \\
\hline SERDP Western Yarrow & 22 & 1 & 24 & 24 & 24 & 0 & 80 \\
\hline Mix 1 - Introduced & 23 & 1 & 4 & 7 & 11 & 69 & 10 \\
\hline Mix 2 - Native & 24 & 1 & 2 & 7 & 5 & 81 & 20 \\
\hline Al Intermediate WG & 25 & 1 & 0 & 4 & 5 & 88 & 10 \\
\hline Mix 3 - Guernsey & 26 & 1 & 15 & 17 & 13 & 38 & 35 \\
\hline Lovington Blue Grama & 27 & 1 & 24 & 24 & 24 & 0 & 80 \\
\hline Mix 4 - core native & 28 & 1 & 15 & 12 & 4 & 57 & 35 \\
\hline Bannock Thickspike WG & 29 & 1 & 6 & 10 & 15 & 57 & 40 \\
\hline Mix 5 - core + Al IWG & 30 & 1 & 16 & 12 & 9 & 49 & 45 \\
\hline Camper Little Bluestem & 31 & 1 & 24 & 24 & 24 & 0 & 75 \\
\hline $\begin{array}{l}\text { Mix } 6 \text { - core + SERDP } \\
\text { Sib.WG }\end{array}$ & 32 & 1 & 4 & 16 & 13 & 54 & 30 \\
\hline Texoka Buffalo Grass & 33 & 1 & 9 & 9 & 15 & 54 & 55 \\
\hline Mix 7 - core + SERDP RWR & 34 & 1 & 7 & 12 & 6 & 65 & 20 \\
\hline Western Yarrow Check & 1 & 2 & 24 & 24 & 24 & 0 & 100 \\
\hline $\begin{array}{l}\text { Mix } 6 \text { - core + SERDP } \\
\text { Sib.WG }\end{array}$ & 2 & 2 & 24 & 21 & 16 & 15 & 60 \\
\hline SERDP Slender WG - Rhiz. & 3 & 2 & 21 & 24 & 23 & 6 & 80 \\
\hline SERDP Western Yarrow & 4 & 2 & 24 & 24 & 24 & 0 & 100 \\
\hline Al Intermediate WG & 5 & 2 & 7 & 9 & 6 & 69 & 10 \\
\hline Mix 1 - Introduced & 6 & 2 & 8 & 20 & 14 & 42 & 35 \\
\hline SERDP TC-2 Western WG & 7 & 2 & 11 & 7 & 7 & 65 & 45 \\
\hline Bannock Thickspike WG & 8 & 2 & 4 & 13 & 8 & 65 & 15 \\
\hline SERDP Snake River WG & 9 & 2 & 18 & 19 & 22 & 18 & 70 \\
\hline Bozoisky RWR & 10 & 2 & 21 & 21 & 12 & 25 & 50 \\
\hline SERDP Syn A RWR & 11 & 2 & 2 & 5 & 0 & 90 & 15 \\
\hline
\end{tabular}




\begin{tabular}{|c|c|c|c|c|c|c|c|}
\hline Entry & Row & Rep & $\begin{array}{l}\text { Number } \\
\text { of } 24 \\
\text { squares } \\
\text { without } \\
\text { plants }\end{array}$ & $\begin{array}{l}\text { Number } \\
\text { of } 24 \\
\text { squares } \\
\text { without } \\
\text { plants }\end{array}$ & $\begin{array}{l}\text { Number } \\
\text { of } 24 \\
\text { squares } \\
\text { without } \\
\text { plants }\end{array}$ & $\begin{array}{l}\text { Percent } \\
\text { stand }\end{array}$ & $\begin{array}{l}\text { \% Weeds } \\
\text { in plots } \\
\text { (visual } \\
\text { est.) }\end{array}$ \\
\hline SERDP Slender WG & 12 & 2 & 1 & 5 & 5 & 85 & 15 \\
\hline SERDP Vavilov Siberian WG & 13 & 2 & 8 & 12 & 6 & 64 & 5 \\
\hline Roadcrest Crested WG & 14 & 2 & 21 & 23 & 22 & 8 & 50 \\
\hline P-7 Bluebunch WG & 15 & 2 & 10 & 12 & 3 & 65 & 30 \\
\hline Vavilov Siberian WG & 16 & 2 & 9 & 11 & 2 & 69 & 1 \\
\hline Mix 2 - Native & 17 & 2 & 9 & 6 & 8 & 68 & 40 \\
\hline Secar Snake River WG & 18 & 2 & 17 & 23 & 24 & 11 & 75 \\
\hline Rosana Western WG & 19 & 2 & 2 & 1 & 3 & 92 & 35 \\
\hline Kazak Pub. Siberian WG & 20 & 2 & 6 & 3 & 3 & 83 & 45 \\
\hline Mix 4 - core native & 21 & 2 & 14 & 4 & 11 & 60 & 65 \\
\hline SB-2 Western WG & 22 & 2 & 5 & 11 & 9 & 65 & 45 \\
\hline SERDP Basin WR & 23 & 2 & 23 & 20 & 23 & 8 & 75 \\
\hline Pryor Slender WG & 24 & 2 & 6 & 3 & 1 & 86 & 10 \\
\hline Lovington Blue Grama & 25 & 2 & 21 & 19 & 24 & 11 & 90 \\
\hline Mix 7 - core + SERDP RWR & 26 & 2 & 6 & 3 & 6 & 79 & 10 \\
\hline Mix 3 - Guernsey & 27 & 2 & 3 & 13 & 15 & 57 & 35 \\
\hline Bozoisky X Tetra RWR & 28 & 2 & 5 & 5 & 7 & 76 & 10 \\
\hline Trailhead Basin WR & 29 & 2 & 22 & 22 & 22 & 8 & 75 \\
\hline Texoka Buffalo Grass & 30 & 2 & 16 & 19 & 23 & 19 & 90 \\
\hline Goldar Bluebunch WG & 31 & 2 & 11 & 14 & 10 & 51 & 40 \\
\hline Flintlock Western WG & 32 & 2 & 6 & 9 & 4 & 74 & 60 \\
\hline Mix 5 - core + Al IWG & 33 & 2 & 4 & 3 & 4 & 85 & 5 \\
\hline Camper Little Bluestem & 34 & 2 & 24 & 24 & 24 & 0 & 80 \\
\hline Pryor Slender WG & 1 & 3 & 20 & 20 & 19 & 18 & 65 \\
\hline SERDP Snake River WG & 2 & 3 & 24 & 24 & 24 & 0 & 90 \\
\hline SERDP Basin WR & 3 & 3 & 24 & 24 & 24 & 0 & 90 \\
\hline Bozoisky RWR & 4 & 3 & 17 & 20 & 10 & 35 & 90 \\
\hline Bannock Thickspike WG & 5 & 3 & 12 & 13 & 9 & 53 & 70 \\
\hline Mix 3 - Guernsey & 6 & 3 & 19 & 17 & 16 & 28 & 65 \\
\hline SB-2 Western WG & 7 & 3 & 12 & 12 & 20 & 39 & 60 \\
\hline Vavilov Siberian WG & 8 & 3 & 3 & 13 & 7 & 68 & 1 \\
\hline Al Intermediate WG & 9 & 3 & 2 & 4 & 5 & 85 & 5 \\
\hline Western Yarrow Check & 10 & 3 & 24 & 24 & 24 & 0 & 80 \\
\hline Mix 1 - Introduced & 11 & 3 & 5 & 6 & 5 & 78 & 5 \\
\hline
\end{tabular}




\begin{tabular}{|c|c|c|c|c|c|c|c|}
\hline Entry & Row & Rep & $\begin{array}{l}\text { Number } \\
\text { of } 24 \\
\text { squares } \\
\text { without } \\
\text { plants }\end{array}$ & $\begin{array}{l}\text { Number } \\
\text { of } 24 \\
\text { squares } \\
\text { without } \\
\text { plants }\end{array}$ & $\begin{array}{l}\text { Number } \\
\text { of } 24 \\
\text { squares } \\
\text { without } \\
\text { plants }\end{array}$ & $\begin{array}{l}\text { Percent } \\
\text { stand }\end{array}$ & $\begin{array}{l}\% \text { Weeds } \\
\text { in plots } \\
\text { (visual } \\
\text { est.) }\end{array}$ \\
\hline Bozoisky X Tetra RWR & 12 & 3 & 7 & 2 & 7 & 78 & 5 \\
\hline SERDP TC-2 Western WG & 13 & 3 & 4 & 11 & 6 & 71 & 25 \\
\hline Kazak Pub. Siberian WG & 14 & 3 & 7 & 10 & 8 & 65 & 25 \\
\hline SERDP Slender WG - Rhiz. & 15 & 3 & 22 & 20 & 18 & 17 & 60 \\
\hline SERDP Vavilov Siberian WG & 16 & 3 & 8 & 7 & 0 & 79 & 0 \\
\hline Mix 7 - core + SERDP RWR & 17 & 3 & 10 & 4 & 8 & 69 & 20 \\
\hline Rosana Western WG & 18 & 3 & 7 & 7 & 8 & 69 & 25 \\
\hline Flintlock Western WG & 19 & 3 & 14 & 5 & 13 & 56 & 40 \\
\hline P-7 Bluebunch WG & 20 & 3 & 7 & 5 & 11 & 68 & 30 \\
\hline Roadcrest Crested WG & 21 & 3 & 15 & 13 & 21 & 32 & 50 \\
\hline Mix 5 - core + Al IWG & 22 & 3 & 4 & 5 & 2 & 85 & 15 \\
\hline Goldar Bluebunch WG & 23 & 3 & 18 & 2 & 14 & 53 & 30 \\
\hline Camper Little Bluestem & 24 & 3 & 24 & 24 & 24 & 0 & 80 \\
\hline Mix 2 - Native & 25 & 3 & 3 & 6 & 6 & 79 & 30 \\
\hline Secar Snake River WG & 26 & 3 & 21 & 22 & 21 & 11 & 75 \\
\hline Trailhead Basin WR & 27 & 3 & 22 & 22 & 24 & 6 & 85 \\
\hline SERDP Western Yarrow & 28 & 3 & 24 & 24 & 24 & 0 & 90 \\
\hline $\begin{array}{l}\text { Mix } 6 \text { - core + SERDP } \\
\text { Sib.WG }\end{array}$ & 29 & 3 & 11 & 4 & 4 & 74 & 5 \\
\hline Lovington Blue Grama & 30 & 3 & 24 & 24 & 24 & 0 & 80 \\
\hline Texoka Buffalo Grass & 31 & 3 & 22 & 24 & 16 & 14 & 85 \\
\hline Mix 4 - core native & 32 & 3 & 5 & 9 & 6 & 72 & 10 \\
\hline SERDP Syn A RWR & 33 & 3 & 10 & 4 & 5 & 74 & 5 \\
\hline SERDP Slender WG & 34 & 3 & 3 & 15 & 13 & 57 & 15 \\
\hline
\end{tabular}


Table 47. Guernsey River site 2-year percent stand, weed, litter, and bare ground data taken June 2006 (visual ratings).

\begin{tabular}{|c|c|c|c|c|c|c|}
\hline Entry & Row & Rep & $\begin{array}{c}\text { \% ground } \\
\text { cover planted } \\
\text { species }\end{array}$ & $\begin{array}{c}\% \\
\text { weeds }\end{array}$ & $\%$ litter & $\begin{array}{l}\% \text { bare } \\
\text { ground }\end{array}$ \\
\hline Al Intermediate WG & 25 & 1 & 48.33 & 0.00 & 26.67 & 25.00 \\
\hline Al Intermediate WG & 5 & 2 & 33.33 & 1.67 & 18.33 & 46.67 \\
\hline Al Intermediate WG & 9 & 3 & 46.67 & 0.00 & 21.67 & 31.67 \\
\hline Bannock Thickspike WG & 29 & 1 & 21.67 & 6.67 & 41.67 & 30.00 \\
\hline Bannock Thickspike WG & 8 & 2 & 46.67 & 0.00 & 16.67 & 36.67 \\
\hline Bannock Thickspike WG & 5 & 3 & 31.67 & 5.00 & 15.00 & 48.33 \\
\hline Bozoisky RWR & 2 & 1 & 26.67 & 3.67 & 15.00 & 54.67 \\
\hline Bozoisky RWR & 10 & 2 & 26.67 & 0.00 & 28.33 & 45.00 \\
\hline Bozoisky RWR & 4 & 3 & 20.00 & 8.33 & 18.33 & 53.33 \\
\hline Bozoisky X Tetra RWR & 1 & 1 & 31.67 & 0.00 & 40.00 & 28.33 \\
\hline Bozoisky X Tetra RWR & 28 & 2 & 26.67 & 0.00 & 28.33 & 45.00 \\
\hline Bozoisky X Tetra RWR & 12 & 3 & 33.33 & 0.00 & 30.00 & 36.67 \\
\hline Camper Little Bluestem & 31 & 1 & 0.00 & 26.67 & 36.67 & 36.67 \\
\hline Camper Little Bluestem & 34 & 2 & 0.00 & 25.00 & 23.33 & 51.67 \\
\hline Camper Little Bluestem & 24 & 3 & 3.33 & 48.33 & 28.33 & 20.00 \\
\hline Flintlock Western WG & 15 & 1 & 10.00 & 3.67 & 30.00 & 56.33 \\
\hline Flintlock Western WG & 32 & 2 & 25.00 & 20.00 & 16.67 & 38.33 \\
\hline Flintlock Western WG & 19 & 3 & 38.33 & 0.00 & 20.00 & 41.67 \\
\hline Goldar Bluebunch WG & 11 & 1 & 16.67 & 3.33 & 11.67 & 68.33 \\
\hline Goldar Bluebunch WG & 31 & 2 & 20.00 & 13.33 & 21.67 & 45.00 \\
\hline Goldar Bluebunch WG & 23 & 3 & 36.67 & 3.33 & 23.33 & 36.67 \\
\hline Kazak Pub. Siberian WG & 8 & 1 & 33.33 & 0.00 & 31.67 & 35.00 \\
\hline Kazak Pub. Siberian WG & 20 & 2 & 35.00 & 0.00 & 30.00 & 35.00 \\
\hline Kazak Pub. Siberian WG & 14 & 3 & 41.67 & 0.00 & 16.67 & 41.67 \\
\hline Lovington Blue Grama & 27 & 1 & 0.00 & 33.33 & 40.00 & 26.67 \\
\hline Lovington Blue Grama & 25 & 2 & 1.67 & 26.67 & 31.67 & 40.00 \\
\hline Lovington Blue Grama & 30 & 3 & 0.00 & 36.67 & 26.67 & 36.67 \\
\hline Mix 1 - Introduced & 23 & 1 & 41.67 & 0.00 & 38.33 & 20.00 \\
\hline Mix 1 - Introduced & 6 & 2 & 43.33 & 0.00 & 13.33 & 43.33 \\
\hline
\end{tabular}




\begin{tabular}{|c|c|c|c|c|c|c|}
\hline Entry & Row & Rep & $\begin{array}{c}\text { \% ground } \\
\text { cover planted } \\
\text { species }\end{array}$ & $\begin{array}{c}\% \\
\text { weeds }\end{array}$ & $\%$ litter & $\begin{array}{l}\% \text { bare } \\
\text { ground }\end{array}$ \\
\hline Mix 1 - Introduced & 11 & 3 & 45.00 & 0.00 & 21.67 & 33.33 \\
\hline Mix 2 - Native & 24 & 1 & 26.67 & 3.33 & 46.67 & 23.33 \\
\hline Mix 2 - Native & 17 & 2 & 38.33 & 6.67 & 16.67 & 38.33 \\
\hline Mix 2 - Native & 25 & 3 & 36.67 & 5.00 & 25.00 & 33.33 \\
\hline Mix 3 - Guernsey & 26 & 1 & 33.33 & 0.00 & 28.33 & 38.33 \\
\hline Mix 3 - Guernsey & 27 & 2 & 31.67 & 1.67 & 21.67 & 45.00 \\
\hline Mix 3 - Guernsey & 6 & 3 & 13.33 & 5.00 & 13.33 & 68.33 \\
\hline Mix 4 - core native & 28 & 1 & 23.33 & 5.00 & 38.33 & 33.33 \\
\hline Mix 4 - core native & 21 & 2 & 35.00 & 6.67 & 18.33 & 40.00 \\
\hline Mix 4 - core native & 32 & 3 & 51.67 & 0.00 & 16.67 & 31.67 \\
\hline Mix 5 - core + Al IWG & 30 & 1 & 38.33 & 10.00 & 26.67 & 25.00 \\
\hline Mix 5 - core + Al IWG & 33 & 2 & 45.00 & 1.67 & 11.67 & 41.67 \\
\hline Mix 5 - core + Al IWG & 22 & 3 & 38.33 & 0.00 & 21.67 & 40.00 \\
\hline Mix 6 - core + SERDP Sib.WG & 32 & 1 & 31.67 & 1.67 & 33.33 & 33.33 \\
\hline Mix 6 - core + SERDP Sib.WG & 2 & 2 & 13.33 & 38.33 & 20.00 & 28.33 \\
\hline Mix 6 - core + SERDP Sib.WG & 29 & 3 & 33.33 & 1.67 & 21.67 & 43.33 \\
\hline Mix 7 - core + SERDP RWR & 34 & 1 & 25.00 & 3.33 & 21.67 & 50.00 \\
\hline Mix 7 - core + SERDP RWR & 26 & 2 & 40.00 & 0.00 & 21.67 & 34.70 \\
\hline Mix 7 - core + SERDP RWR & 17 & 3 & 40.00 & 1.67 & 18.33 & 40.00 \\
\hline P-7 Bluebunch WG & 12 & 1 & 6.67 & 11.67 & 36.67 & 45.00 \\
\hline P-7 Bluebunch WG & 15 & 2 & 38.33 & 1.67 & 20.00 & 40.00 \\
\hline P-7 Bluebunch WG & 20 & 3 & 40.00 & 1.67 & 21.67 & 36.67 \\
\hline Pryor Slender WG & 4 & 1 & 8.33 & 6.67 & 46.67 & 38.33 \\
\hline Pryor Slender WG & 24 & 2 & 26.67 & 3.33 & 25.00 & 45.00 \\
\hline Pryor Slender WG & 1 & 3 & 8.33 & 48.33 & 23.33 & 20.00 \\
\hline Roadcrest Crested WG & 7 & 1 & 0.00 & 25.00 & 50.00 & 25.00 \\
\hline Roadcrest Crested WG & 14 & 2 & 31.67 & 1.67 & 28.33 & 38.33 \\
\hline Roadcrest Crested WG & 21 & 3 & 21.67 & 0.33 & 15.00 & 63.00 \\
\hline Rosana Western WG & 17 & 1 & 40.00 & 1.67 & 21.67 & 36.67 \\
\hline Rosana Western WG & 19 & 2 & 35.00 & 0.00 & 31.00 & 34.00 \\
\hline Rosana Western WG & 18 & 3 & 45.00 & 0.33 & 23.33 & 31.33 \\
\hline
\end{tabular}




\begin{tabular}{|c|c|c|c|c|c|c|}
\hline Entry & Row & Rep & $\begin{array}{c}\text { \% ground } \\
\text { cover planted } \\
\text { species }\end{array}$ & $\begin{array}{c}\% \\
\text { weeds }\end{array}$ & $\%$ litter & $\begin{array}{l}\% \text { bare } \\
\text { ground }\end{array}$ \\
\hline SB-2 Western WG & 16 & 1 & 30.00 & 11.67 & 21.67 & 36.67 \\
\hline SB-2 Western WG & 22 & 2 & 20.00 & 1.67 & 21.67 & 56.67 \\
\hline SB-2 Western WG & 7 & 3 & 16.67 & 6.67 & 18.33 & 58.33 \\
\hline Secar Snake River WG & 13 & 1 & 1.67 & 21.67 & 40.00 & 36.67 \\
\hline Secar Snake River WG & 18 & 2 & 20.00 & 5.00 & 35.00 & 40.00 \\
\hline Secar Snake River WG & 26 & 3 & 21.67 & 11.67 & 20.00 & 46.67 \\
\hline SERDP Basin WR & 20 & 1 & 8.33 & 25.00 & 25.00 & 41.67 \\
\hline SERDP Basin WR & 23 & 2 & 0.00 & 20.00 & 20.00 & 60.00 \\
\hline SERDP Basin WR & 3 & 3 & 0.00 & 43.33 & 21.67 & 35.00 \\
\hline SERDP Slender WG & 5 & 1 & 53.33 & 0.00 & 16.67 & 30.00 \\
\hline SERDP Slender WG & 12 & 2 & 31.67 & 0.00 & 15.00 & 53.33 \\
\hline SERDP Slender WG & 34 & 3 & 26.67 & 3.33 & 25.00 & 45.00 \\
\hline SERDP Slender WG - Rhiz. & 6 & 1 & 8.33 & 20.00 & 43.33 & 28.33 \\
\hline SERDP Slender WG - Rhiz. & 3 & 2 & 6.67 & 36.67 & 15.00 & 41.67 \\
\hline SERDP Slender WG - Rhiz. & 15 & 3 & 8.33 & 6.67 & 21.67 & 63.33 \\
\hline SERDP Snake River WG & 14 & 1 & 0.00 & 21.67 & 48.33 & 30.00 \\
\hline SERDP Snake River WG & 9 & 2 & 20.00 & 5.00 & 15.00 & 60.00 \\
\hline SERDP Snake River WG & 2 & 3 & 1.67 & 50.00 & 16.67 & 31.67 \\
\hline SERDP Syn A RWR & 3 & 1 & 30.00 & 0.33 & 23.33 & 46.33 \\
\hline SERDP Syn A RWR & 11 & 2 & 46.67 & 0.00 & 30.00 & 23.33 \\
\hline SERDP Syn A RWR & 33 & 3 & 35.00 & 0.00 & 30.00 & 35.00 \\
\hline SERDP TC-2 Western WG & 18 & 1 & 56.67 & 0.00 & 23.33 & 20.00 \\
\hline SERDP TC-2 Western WG & 7 & 2 & 38.33 & 1.67 & 25.00 & 35.00 \\
\hline SERDP TC-2 Western WG & 13 & 3 & 38.33 & 1.67 & 21.67 & 38.33 \\
\hline SERDP Vavilov Siberian WG & 10 & 1 & 36.67 & 0.00 & 18.33 & 45.00 \\
\hline SERDP Vavilov Siberian WG & 13 & 2 & 41.67 & 0.00 & 20.00 & 38.33 \\
\hline SERDP Vavilov Siberian WG & 16 & 3 & 43.33 & 1.67 & 21.67 & 33.33 \\
\hline SERDP Western Yarrow & 22 & 1 & 0.00 & 23.33 & 46.67 & 30.00 \\
\hline SERDP Western Yarrow & 4 & 2 & 0.00 & 46.67 & 15.00 & 38.33 \\
\hline SERDP Western Yarrow & 28 & 3 & 0.00 & 35.00 & 35.00 & 30.00 \\
\hline Texoka Buffalo Grass & 33 & 1 & 48.33 & 1.67 & 21.67 & 28.33 \\
\hline
\end{tabular}




\begin{tabular}{|l|r|r|c|c|c|c|}
\hline Entry & Row & Rep & $\begin{array}{c}\text { \% ground } \\
\text { cover planted } \\
\text { species }\end{array}$ & $\begin{array}{c}\% \\
\text { weeds }\end{array}$ & \% litter & $\begin{array}{c}\text { \% bare } \\
\text { ground }\end{array}$ \\
\hline Texoka Buffalo Grass & 30 & 2 & 20.00 & 13.33 & 43.33 & 23.33 \\
\hline Texoka Buffalo Grass & 31 & 3 & 25.00 & 26.67 & 25.00 & 23.33 \\
\hline Trailhead Basin WR & 19 & 1 & 21.67 & 15.33 & 20.00 & 43.00 \\
\hline Trailhead Basin WR & 29 & 2 & 5.00 & 45.00 & 30.00 & 20.00 \\
\hline Trailhead Basin WR & 27 & 3 & 13.33 & 25.00 & 25.00 & 36.67 \\
\hline Vavilov Siberian WG & 9 & 1 & 50.00 & 1.67 & 18.33 & 30.00 \\
\hline Vavilov Siberian WG & 16 & 2 & 28.33 & 0.00 & 11.67 & 60.00 \\
\hline Vavilov Siberian WG & 8 & 3 & 36.67 & 0.00 & 16.67 & 46.67 \\
\hline Western Yarrow Check & 21 & 1 & 0.00 & 33.33 & 33.33 & 33.33 \\
\hline Western Yarrow Check & 1 & 2 & 0.00 & 33.33 & 30.00 & 36.67 \\
\hline Western Yarrow Check & 10 & 3 & 0.00 & 40.00 & 28.33 & 31.67 \\
\hline
\end{tabular}

The Guernsey Tower site was planted 23 March 2005 (Table 48).

Establishment data were taken 2 months later on 2 June 2005 (Table 49). Coverage data were taken 1 year later in June 2006 (Table 50); no data were taken in 2007 because of drought conditions.

Table 48. Camp Guernsey Tower site monoculture 2-month establishment data taken 2 June 2005 (48-grid frame; $6.35 \times 6.35 \mathrm{~cm}$ squares).

\begin{tabular}{|l|r|r|l|r|l|r|r|}
\hline & Row & Rep & $\begin{array}{l}\text { Number } \\
\text { of } \\
\text { squares } \\
\text { without } \\
\text { plants } \\
\text { (out of } \\
\text { En) }\end{array}$ & $\begin{array}{l}\text { Number } \\
\text { of } \\
\text { squares } \\
\text { without } \\
\text { plants } \\
\text { (out of } \\
\text { 48) }\end{array}$ & $\begin{array}{l}\text { Number } \\
\text { of } \\
\text { squares } \\
\text { without } \\
\text { plants } \\
\text { (out of } \\
48)\end{array}$ & $\begin{array}{l}\text { Percent } \\
\text { stand }\end{array}$ & $\begin{array}{l}\text { Average } \\
\text { percent } \\
\text { stand by } \\
\text { entry }\end{array}$ \\
\hline P-7 Bluebunch WG & 12 & 1 & 11 & 14 & 10 & 76 & 56 \\
\hline P-7 Bluebunch WG & 15 & 2 & 27 & 30 & 43 & 31 & \\
\hline P-7 Bluebunch WG & 20 & 3 & 30 & 9 & 17 & 61 & \\
\hline Goldar Bluebunch WG & 11 & 1 & 16 & 19 & 16 & 65 & 55 \\
\hline Goldar Bluebunch WG & 31 & 2 & 10 & 23 & 28 & 58 & \\
\hline Goldar Bluebunch WG & 23 & 3 & 26 & 21 & 35 & 43 & \\
\hline SERDP Basin WR & 20 & 1 & 19 & 31 & 34 & 42 & \\
\hline SERDP Basin WR & 23 & 2 & 37 & 37 & 34 & 25 & \\
\hline SERDP Basin WR & 3 & 3 & 27 & 28 & 13 & 53 & \\
\hline
\end{tabular}




\begin{tabular}{|c|c|c|c|c|c|c|c|}
\hline Entry & Row & $\operatorname{Rep}$ & $\begin{array}{l}\text { Number } \\
\text { of } \\
\text { squares } \\
\text { without } \\
\text { plants } \\
\text { (out of } \\
48 \text { ) }\end{array}$ & $\begin{array}{l}\text { Number } \\
\text { of } \\
\text { squares } \\
\text { without } \\
\text { plants } \\
\text { (out of } \\
48 \text { ) }\end{array}$ & $\begin{array}{l}\text { Number } \\
\text { of } \\
\text { squares } \\
\text { without } \\
\text { plants } \\
\text { (out of } \\
48 \text { ) }\end{array}$ & $\begin{array}{l}\text { Percent } \\
\text { stand }\end{array}$ & $\begin{array}{l}\text { Average } \\
\text { percent } \\
\text { stand by } \\
\text { entry }\end{array}$ \\
\hline Trailhead Basin WR & 19 & 1 & 26 & 35 & 40 & 30 & 50 \\
\hline Trailhead Basin WR & 29 & 2 & 11 & 6 & 8 & 83 & \\
\hline Trailhead Basin WR & 27 & 3 & 22 & 41 & 25 & 39 & \\
\hline SERDP Syn A RWR & 3 & 1 & 23 & 22 & 10 & 62 & 50 \\
\hline SERDP Syn A RWR & 11 & 2 & 20 & 30 & 13 & 56 & \\
\hline SERDP Syn A RWR & 33 & 3 & 35 & 36 & 26 & 33 & \\
\hline Bozoisky RWR & 2 & 1 & 18 & 6 & 17 & 72 & 65 \\
\hline Bozoisky RWR & 10 & 2 & 23 & 24 & 19 & 54 & \\
\hline Bozoisky RWR & 4 & 3 & 18 & 15 & 11 & 69 & \\
\hline Pryor Slender WG & 4 & 1 & 19 & 18 & 29 & 54 & 37 \\
\hline Pryor Slender WG & 24 & 2 & 34 & 42 & 38 & 21 & \\
\hline Pryor Slender WG & 1 & 3 & 39 & 26 & 28 & 35 & \\
\hline SERDP Slender WG & 5 & 1 & 10 & 28 & 14 & 64 & 62 \\
\hline SERDP Slender WG & 12 & 2 & 18 & 21 & 17 & 61 & \\
\hline SERDP Slender WG & 34 & 3 & 16 & 24 & 17 & 60 & \\
\hline Secar Snake River WG & 13 & 1 & 22 & 28 & 16 & 54 & 44 \\
\hline Secar Snake River WG & 18 & 2 & 27 & 23 & 31 & 44 & \\
\hline Secar Snake River WG & 26 & 3 & 24 & 38 & 35 & 33 & \\
\hline SERDP Snake River WG & 14 & 1 & 27 & 19 & 28 & 49 & 55 \\
\hline SERDP Snake River WG & 9 & 2 & 38 & 24 & 33 & 34 & \\
\hline SERDP Snake River WG & 2 & 3 & 9 & 6 & 12 & 81 & \\
\hline $\begin{array}{l}\text { SERDP Vavilov Siberian } \\
\text { WG }\end{array}$ & 10 & 1 & 21 & 10 & 9 & 72 & 68 \\
\hline $\begin{array}{l}\text { SERDP Vavilov Siberian } \\
\text { WG }\end{array}$ & 13 & 2 & 13 & 19 & 21 & 63 & \\
\hline $\begin{array}{l}\text { SERDP Vavilov Siberian } \\
\text { WG }\end{array}$ & 16 & 3 & 19 & 19 & 9 & 67 & \\
\hline Vavilov Siberian WG & 9 & 1 & 17 & 9 & 16 & 71 & 65 \\
\hline Vavilov Siberian WG & 16 & 2 & 30 & 20 & 17 & 53 & \\
\hline Vavilov Siberian WG & 8 & 3 & 21 & 16 & 4 & 72 & \\
\hline Rosana Western WG & 17 & 1 & 21 & 39 & 31 & 37 & 39 \\
\hline Rosana Western WG & 19 & 2 & 39 & 29 & 25 & 35 & \\
\hline Rosana Western WG & 18 & 3 & 23 & 30 & 26 & 45 & \\
\hline
\end{tabular}




\begin{tabular}{|l|r|r|r|l|l|r|r|}
\hline & Row & Rep & $\begin{array}{l}\text { Number } \\
\text { of } \\
\text { squares } \\
\text { without } \\
\text { plants } \\
\text { (out of } \\
\text { 48) }\end{array}$ & $\begin{array}{l}\text { Number } \\
\text { of } \\
\text { squares } \\
\text { without } \\
\text { plants } \\
\text { (out of } \\
\text { 48) }\end{array}$ & $\begin{array}{l}\text { Number } \\
\text { of } \\
\text { squares } \\
\text { without } \\
\text { plants } \\
\text { (out of } \\
\text { Entry }\end{array}$ & $\begin{array}{l}\text { Percent } \\
\text { stand }\end{array}$ & $\begin{array}{l}\text { Average } \\
\text { percent } \\
\text { stand by } \\
\text { entry }\end{array}$ \\
\hline $\begin{array}{l}\text { SERDP TC-2 Western } \\
\text { WG }\end{array}$ & 18 & 1 & 27 & 25 & 40 & 36 & 51 \\
\hline $\begin{array}{l}\text { SERDP TC-2 Western } \\
\text { WG }\end{array}$ & 7 & 2 & 25 & 27 & 19 & 51 & \\
\hline $\begin{array}{l}\text { SERDP TC-2 Western } \\
\text { WG }\end{array}$ & 13 & 3 & 21 & 16 & 12 & 66 & \\
\hline SERDP Western Yarrow & 22 & 1 & 48 & 48 & 48 & 0 & \\
\hline SERDP Western Yarrow & 4 & 2 & 48 & 48 & 48 & 0 & \\
\hline SERDP Western Yarrow & 28 & 3 & 47 & 48 & 48 & 1 & \\
\hline Western Yarrow Check & 21 & 1 & 48 & 48 & 48 & 0 & \\
\hline Western Yarrow Check & 1 & 2 & 48 & 48 & 48 & 0 & \\
\hline Western Yarrow Check & 10 & 3 & 48 & 48 & 48 & 0 & \\
\hline
\end{tabular}

Table 49. Guernsey Tower site mix 2-month establishment data taken 2 June 2005 (48-grid frame with $6.35 \times 6.35 \mathrm{~cm}$ squares).

\begin{tabular}{|c|c|c|c|c|c|c|}
\hline Entry & Row & Rep & $\begin{array}{l}\text { Number } \\
\text { of } \\
\text { squares } \\
\text { without } \\
\text { plants } \\
\text { (out of } \\
48 \text { ) }\end{array}$ & $\begin{array}{l}\text { Number } \\
\text { of } \\
\text { squares } \\
\text { without } \\
\text { plants } \\
\text { (out of } \\
48 \text { ) }\end{array}$ & $\begin{array}{l}\text { Number } \\
\text { of } \\
\text { squares } \\
\text { without } \\
\text { plants } \\
\text { (out of } \\
48 \text { ) }\end{array}$ & $\begin{array}{l}\text { Percent } \\
\text { stand }\end{array}$ \\
\hline Mix 1 - Introduced & 23 & 1 & 24 & 26 & 28 & 46 \\
\hline Mix 1 - Introduced & 6 & 2 & 24 & 25 & 20 & 52 \\
\hline Mix 1 - Introduced & 11 & 3 & 14 & 14 & 11 & 73 \\
\hline Mix 2 - Native & 24 & 1 & 19 & 22 & 23 & 56 \\
\hline Mix 2 - Native & 17 & 2 & 32 & 24 & 19 & 48 \\
\hline Mix 2 - Native & 25 & 3 & 27 & 27 & 23 & 47 \\
\hline Mix 3 - Guernsey & 26 & 1 & 33 & 36 & 40 & 24 \\
\hline Mix 3 - Guernsey & 27 & 2 & 24 & 40 & 40 & 28 \\
\hline Mix 3 - Guernsey & 6 & 3 & 41 & 31 & 37 & 24 \\
\hline Mix 4 - core native & 28 & 1 & 21 & 16 & 32 & 52 \\
\hline Mix 4 - core native & 21 & 2 & 18 & 23 & 29 & 51 \\
\hline Mix 4 - core native & 32 & 3 & 21 & 41 & 30 & 36 \\
\hline Mix 5 - core + Al IWG & 30 & 1 & 26 & 35 & 25 & 40 \\
\hline
\end{tabular}




\begin{tabular}{|c|c|c|c|c|c|c|}
\hline Entry & Row & $\operatorname{Rep}$ & $\begin{array}{l}\text { Number } \\
\text { of } \\
\text { squares } \\
\text { without } \\
\text { plants } \\
\text { (out of } \\
48 \text { ) }\end{array}$ & $\begin{array}{l}\text { Number } \\
\text { of } \\
\text { squares } \\
\text { without } \\
\text { plants } \\
\text { (out of } \\
48 \text { ) }\end{array}$ & $\begin{array}{l}\text { Number } \\
\text { of } \\
\text { squares } \\
\text { without } \\
\text { plants } \\
\text { (out of } \\
48 \text { ) }\end{array}$ & $\begin{array}{l}\text { Percent } \\
\text { stand }\end{array}$ \\
\hline Mix 5 - core + Al IWG & 33 & 2 & 24 & 35 & 19 & 46 \\
\hline Mix 5 - core + Al IWG & 22 & 3 & 36 & 19 & 32 & 40 \\
\hline Mix 6 - core + SERDP Sib.WG & 32 & 1 & 37 & 39 & 21 & 33 \\
\hline Mix 6 - core + SERDP Sib.WG & 2 & 2 & 24 & 19 & 16 & 59 \\
\hline Mix 6 - core + SERDP Sib.WG & 29 & 3 & 31 & 25 & 30 & 40 \\
\hline Mix 7 - core + SERDP RWR & 34 & 1 & 44 & 32 & 45 & 16 \\
\hline Mix 7 - core + SERDP RWR & 26 & 2 & 6 & 26 & 24 & 61 \\
\hline Mix 7 - core + SERDP RWR & 17 & 3 & 10 & 23 & 27 & 58 \\
\hline
\end{tabular}


Table 50. Guernsey Tower site 1-year percent stand, weed, litter, and bare ground data taken June 2006 (visual ratings).

\begin{tabular}{|c|c|c|c|c|c|c|}
\hline \multirow[b]{2}{*}{ Entry } & \multirow[b]{2}{*}{ Row } & \multirow[b]{2}{*}{$\operatorname{Rep}$} & \multicolumn{4}{|c|}{ As percentage (\%) } \\
\hline & & & $\begin{array}{l}\text { Ground cover } \\
\text { planted species }\end{array}$ & Weeds & Litter & $\begin{array}{l}\text { Bare } \\
\text { ground }\end{array}$ \\
\hline Al Intermediate WG & 25 & 1 & 15.00 & 9.00 & 16.67 & 59.33 \\
\hline Al Intermediate WG & 5 & 2 & 20.00 & 2.33 & 21.67 & 56.00 \\
\hline Al Intermediate WG & 9 & 3 & 21.67 & 0.00 & 8.67 & 69.67 \\
\hline Bannock Thickspike WG & 29 & 1 & 18.33 & 4.00 & 18.33 & 59.33 \\
\hline Bannock Thickspike WG & 8 & 2 & 11.67 & 7.33 & 33.33 & 47.67 \\
\hline Bannock Thickspike WG & 5 & 3 & 20.00 & 2.33 & 8.33 & 69.33 \\
\hline Bozoisky RWR & 2 & 1 & 28.33 & 0.33 & 25.00 & 46.33 \\
\hline Bozoisky RWR & 10 & 2 & 11.67 & 2.00 & 20.00 & 66.33 \\
\hline Bozoisky RWR & 4 & 3 & 13.33 & 1.67 & 15.00 & 70.00 \\
\hline Bozoisky X Tetra RWR & 1 & 1 & 28.33 & 0.00 & 18.33 & 53.33 \\
\hline Bozoisky X Tetra RWR & 28 & 2 & 16.67 & 2.00 & 8.33 & 73.00 \\
\hline Bozoisky X Tetra RWR & 12 & 3 & 8.33 & 0.00 & 20.00 & 1.30 \\
\hline Camper Little Bluestem & 31 & 1 & 13.33 & 13.33 & 18.33 & 55.00 \\
\hline Camper Little Bluestem & 34 & 2 & 0.00 & 20.33 & 11.67 & 68.00 \\
\hline Camper Little Bluestem & 24 & 3 & 3.33 & 21.67 & 18.33 & 56.67 \\
\hline Flintlock Western WG & 15 & 1 & 10.00 & 11.67 & 25.00 & 53.33 \\
\hline Flintlock Western WG & 32 & 2 & 3.33 & 10.00 & 7.00 & 79.67 \\
\hline Flintlock Western WG & 19 & 3 & 20.00 & 10.67 & 15.00 & 54.33 \\
\hline Goldar Bluebunch WG & 11 & 1 & 31.67 & 5.00 & 11.67 & 51.67 \\
\hline Goldar Bluebunch WG & 31 & 2 & 16.67 & 0.67 & 13.33 & 69.33 \\
\hline Goldar Bluebunch WG & 23 & 3 & 13.33 & 1.60 & 17.00 & 4.38 \\
\hline Kazak Pub. Siberian WG & 8 & 1 & 23.33 & 5.33 & 20.00 & 51.33 \\
\hline Kazak Pub. Siberian WG & 20 & 2 & 23.33 & 3.33 & 12.00 & 61.33 \\
\hline Kazak Pub. Siberian WG & 14 & 3 & 18.33 & 2.00 & 11.67 & 3.40 \\
\hline Lovington Blue Grama & 27 & 1 & 8.33 & 15.00 & 28.33 & 48.33 \\
\hline Lovington Blue Grama & 25 & 2 & 0.33 & 15.00 & 11.67 & 73.00 \\
\hline Lovington Blue Grama & 30 & 3 & 0.00 & 16.67 & 15.00 & 68.33 \\
\hline Mix 1 - Introduced & 23 & 1 & 25.00 & 2.33 & 15.00 & 57.67 \\
\hline Mix 1 - Introduced & 6 & 2 & 38.33 & 5.00 & 15.00 & 41.67 \\
\hline
\end{tabular}




\begin{tabular}{|c|c|c|c|c|c|c|}
\hline \multirow[b]{2}{*}{ Entry } & \multirow[b]{2}{*}{ Row } & \multirow[b]{2}{*}{$\operatorname{Rep}$} & \multicolumn{4}{|c|}{ As percentage (\%) } \\
\hline & & & $\begin{array}{l}\text { Ground cover } \\
\text { planted species }\end{array}$ & Weeds & Litter & $\begin{array}{l}\text { Bare } \\
\text { ground }\end{array}$ \\
\hline Mix 1 - Introduced & 11 & 3 & 21.67 & 3.33 & 13.33 & 61.67 \\
\hline Mix 2 - Native & 24 & 1 & 15.00 & 10.00 & 16.67 & 58.33 \\
\hline Mix 2 - Native & 17 & 2 & 25.00 & 0.67 & 11.67 & 62.67 \\
\hline Mix 2 - Native & 25 & 3 & 16.67 & 5.00 & 18.33 & 5.44 \\
\hline Mix 3 - Guernsey & 26 & 1 & 15.00 & 5.00 & 20.00 & 60.00 \\
\hline Mix 3 - Guernsey & 27 & 2 & 10.00 & 5.00 & 8.67 & 76.33 \\
\hline Mix 3 - Guernsey & 6 & 3 & 3.33 & 5.33 & 13.33 & 78.00 \\
\hline Mix 4 - core native & 28 & 1 & 31.67 & 4.00 & 23.33 & 41.00 \\
\hline Mix 4 - core native & 21 & 2 & 21.67 & 3.67 & 16.67 & 58.00 \\
\hline Mix 4 - core native & 32 & 3 & 16.67 & 5.00 & 15.00 & 63.33 \\
\hline Mix 5 - core + Al IWG & 30 & 1 & 25.00 & 7.00 & 15.00 & 53.00 \\
\hline Mix 5 - core + Al IWG & 33 & 2 & 18.33 & 0.67 & 11.67 & 69.33 \\
\hline Mix 5 - core + Al IWG & 22 & 3 & 15.00 & 5.33 & 12.00 & 67.67 \\
\hline Mix 6 - core + SERDP Sib.WG & 32 & 1 & 20.00 & 6.67 & 25.00 & 48.33 \\
\hline Mix 6 - core + SERDP Sib.WG & 2 & 2 & 20.00 & 5.00 & 13.33 & 61.67 \\
\hline Mix 6 - core + SERDP Sib.WG & 29 & 3 & 31.67 & 0.33 & 16.67 & 51.33 \\
\hline Mix 7 - core + SERDP RWR & 34 & 1 & 8.33 & 13.33 & 16.67 & 61.67 \\
\hline Mix 7 - core + SERDP RWR & 26 & 2 & 25.00 & 3.67 & 10.00 & 61.33 \\
\hline Mix 7 - core + SERDP RWR & 17 & 3 & 16.67 & 3.67 & 11.67 & 68.00 \\
\hline P-7 Bluebunch WG & 12 & 1 & 25.00 & 3.67 & 11.67 & 59.67 \\
\hline P-7 Bluebunch WG & 15 & 2 & 25.00 & 3.67 & 10.33 & 61.00 \\
\hline P-7 Bluebunch WG & 20 & 3 & 25.00 & 0.33 & 10.00 & 64.67 \\
\hline Pryor Slender WG & 4 & 1 & 41.67 & 2.00 & 21.67 & 34.67 \\
\hline Pryor Slender WG & 24 & 2 & 26.67 & 5.67 & 11.67 & 56.00 \\
\hline Pryor Slender WG & 1 & 3 & 28.33 & 3.67 & 6.67 & 61.33 \\
\hline Roadcrest Crested WG & 7 & 1 & 21.67 & 3.33 & 18.33 & 56.67 \\
\hline Roadcrest Crested WG & 14 & 2 & 20.00 & 3.67 & 15.00 & 61.33 \\
\hline Roadcrest Crested WG & 21 & 3 & 13.33 & 1.60 & 13.33 & 4.88 \\
\hline Rosana Western WG & 17 & 1 & 26.67 & 3.67 & 10.00 & 59.67 \\
\hline Rosana Western WG & 19 & 2 & 26.67 & 2.00 & 26.67 & 44.67 \\
\hline
\end{tabular}




\begin{tabular}{|c|c|c|c|c|c|c|}
\hline \multirow[b]{2}{*}{ Entry } & \multirow[b]{2}{*}{ Row } & \multirow[b]{2}{*}{$\operatorname{Rep}$} & \multicolumn{4}{|c|}{ As percentage (\%) } \\
\hline & & & $\begin{array}{l}\text { Ground cover } \\
\text { planted species }\end{array}$ & Weeds & Litter & $\begin{array}{l}\text { Bare } \\
\text { ground }\end{array}$ \\
\hline Rosana Western WG & 18 & 3 & 15.00 & 3.33 & 13.33 & 68.33 \\
\hline SB-2 Western WG & 16 & 1 & 28.33 & 5.00 & 11.67 & 55.00 \\
\hline SB-2 Western WG & 22 & 2 & 11.67 & 5.33 & 23.33 & 59.67 \\
\hline SB-2 Western WG & 7 & 3 & 15.00 & 5.33 & 11.67 & 68.00 \\
\hline Secar Snake River WG & 13 & 1 & 23.33 & 5.00 & 16.67 & 55.00 \\
\hline Secar Snake River WG & 18 & 2 & 20.00 & 3.67 & 11.67 & 64.67 \\
\hline Secar Snake River WG & 26 & 3 & 13.33 & 10.00 & 13.33 & 63.33 \\
\hline SERDP Basin WR & 20 & 1 & 0.00 & 20.00 & 28.33 & 51.67 \\
\hline SERDP Basin WR & 23 & 2 & 3.33 & 16.67 & 15.00 & 65.00 \\
\hline SERDP Basin WR & 3 & 3 & 5.00 & 6.60 & 10.00 & 1.00 \\
\hline SERDP Slender WG & 5 & 1 & 46.67 & 0.00 & 18.33 & 35.00 \\
\hline SERDP Slender WG & 12 & 2 & 26.67 & 4.00 & 13.33 & 56.00 \\
\hline SERDP Slender WG & 34 & 3 & 41.67 & 0.00 & 11.67 & 46.67 \\
\hline SERDP Slender WG - Rhiz. & 6 & 1 & 31.67 & 3.67 & 43.33 & 21.33 \\
\hline SERDP Slender WG - Rhiz. & 3 & 2 & 13.33 & 3.67 & 36.67 & 46.33 \\
\hline SERDP Slender WG - Rhiz. & 15 & 3 & 15.00 & 8.33 & 18.33 & 58.33 \\
\hline SERDP Snake River WG & 14 & 1 & 21.67 & 3.33 & 23.33 & 51.67 \\
\hline SERDP Snake River WG & 9 & 2 & 20.00 & 6.67 & 21.67 & 51.67 \\
\hline SERDP Snake River WG & 2 & 3 & 13.33 & 1.67 & 10.00 & 75.00 \\
\hline SERDP Syn A RWR & 3 & 1 & 30.00 & 1.67 & 38.33 & 30.00 \\
\hline SERDP Syn A RWR & 11 & 2 & 13.33 & 5.33 & 13.33 & 68.00 \\
\hline SERDP Syn A RWR & 33 & 3 & 25.00 & 3.33 & 11.67 & 60.00 \\
\hline SERDP TC-2 Western WG & 18 & 1 & 21.67 & 8.33 & 16.67 & 53.33 \\
\hline SERDP TC-2 Western WG & 7 & 2 & 10.00 & 7.00 & 16.67 & 66.33 \\
\hline SERDP TC-2 Western WG & 13 & 3 & 15.00 & 7.00 & 10.00 & 68.00 \\
\hline SERDP Vavilov Siberian WG & 10 & 1 & 33.33 & 5.33 & 11.67 & 49.67 \\
\hline SERDP Vavilov Siberian WG & 13 & 2 & 16.67 & 3.33 & 11.67 & 68.33 \\
\hline SERDP Vavilov Siberian WG & 16 & 3 & 21.67 & 2.00 & 13.33 & 63.00 \\
\hline SERDP Western Yarrow & 22 & 1 & 0.00 & 20.00 & 20.00 & 60.00 \\
\hline SERDP Western Yarrow & 4 & 2 & 0.00 & 25.00 & 8.33 & 66.67 \\
\hline
\end{tabular}




\begin{tabular}{|c|c|c|c|c|c|c|}
\hline \multirow[b]{2}{*}{ Entry } & \multirow[b]{2}{*}{ Row } & \multirow[b]{2}{*}{ Rep } & \multicolumn{4}{|c|}{ As percentage (\%) } \\
\hline & & & $\begin{array}{l}\text { Ground cover } \\
\text { planted species }\end{array}$ & Weeds & Litter & $\begin{array}{l}\text { Bare } \\
\text { ground }\end{array}$ \\
\hline SERDP Western Yarrow & 28 & 3 & 3.33 & 20.00 & 11.67 & 65.00 \\
\hline Texoka Buffalo Grass & 33 & 1 & 18.33 & 10.00 & 11.67 & 60.00 \\
\hline Texoka Buffalo Grass & 30 & 2 & 26.67 & 10.33 & 8.67 & 54.33 \\
\hline Texoka Buffalo Grass & 31 & 3 & 16.67 & 11.67 & 16.67 & 55.00 \\
\hline Trailhead Basin WR & 19 & 1 & 0.00 & 25.00 & 15.00 & 60.00 \\
\hline Trailhead Basin WR & 29 & 2 & 18.33 & 4.00 & 18.33 & 59.33 \\
\hline Trailhead Basin WR & 27 & 3 & 0.00 & 0.00 & 0.00 & 0.00 \\
\hline Vavilov Siberian WG & 9 & 1 & 23.33 & 5.33 & 10.00 & 61.33 \\
\hline Vavilov Siberian WG & 16 & 2 & 18.33 & 2.00 & 17.00 & 62.67 \\
\hline Vavilov Siberian WG & 8 & 3 & 16.67 & 0.33 & 10.00 & 73.00 \\
\hline Western Yarrow Check & 21 & 1 & 0.00 & 13.33 & 13.33 & 73.33 \\
\hline Western Yarrow Check & 1 & 2 & 5.00 & 31.67 & 11.67 & 51.67 \\
\hline Western Yarrow Check & 10 & 3 & 0.00 & 20.00 & 10.33 & 69.67 \\
\hline
\end{tabular}

\section{D.7 Fort Drum data (mixtures)}

The 4 years of data (2003-2006) from the Fort Drum airport site are shown below in Table 51 - Table 54 . 
Table 51. Fort Drum Airport site 1-year percent cover and bare ground on 24 June 2003.

\begin{tabular}{|c|c|c|c|c|c|c|c|c|c|}
\hline & Treatment & WL & $\mathrm{FF}$ & SG & $H G$ & $\begin{array}{c}\text { Total } \\
\text { sown } \\
\text { species }\end{array}$ & $\begin{array}{l}\text { Other } \\
\text { species }\end{array}$ & Dead WL & $\begin{array}{l}\text { Bare } \\
\text { ground }\end{array}$ \\
\hline 1 & $\begin{array}{l}\text { Weeping } \\
\text { lovegrass }\end{array}$ & 53 & - & -- & -- & 53 & 15 & 32 & 0 \\
\hline 2 & $\begin{array}{l}\text { Weeping } \\
\text { lovegrass + } \\
\text { hairgrass }\end{array}$ & 79 & -- & -- & 0 & 79 & 5 & 12 & 4 \\
\hline 3 & $\begin{array}{l}\text { Weeping } \\
\text { lovegrass + } \\
\text { switchgrass }\end{array}$ & 8 & -- & 42 & -- & 49 & 24 & 23 & 4 \\
\hline 4 & $\begin{array}{l}\text { Weeping } \\
\text { lovegrass + } \\
\text { switchgrass + } \\
\text { hairgrass }\end{array}$ & 42 & -- & 14 & 0 & 56 & 11 & 28 & 5 \\
\hline 5 & $\begin{array}{l}\text { Weeping } \\
\text { lovegrass + } \\
\text { hairgrass + } \\
\text { switchgrass + } \\
\text { fine fescues }\end{array}$ & 31 & 21 & 3 & 0 & 55 & 3 & 19 & 2 \\
\hline 6 & $\begin{array}{l}\text { Weeping } \\
\text { lovegrass + } \\
\text { hairgrasses + } \\
\text { fine fescues }\end{array}$ & 35 & 9 & -- & 0 & 45 & 11 & 18 & 27 \\
\hline 7 & $\begin{array}{l}\text { Weeping } \\
\text { lovegrass + } \\
\text { switchgrass + } \\
\text { fine fescues }\end{array}$ & 13 & 19 & 43 & -- & 75 & 11 & 7 & 9 \\
\hline 8 & $\begin{array}{l}\text { Weeping } \\
\text { lovegrass }+ \\
\text { fine fescues }\end{array}$ & 24 & 36 & -- & -- & 60 & 18 & 18 & 5 \\
\hline & LSD @ 0.05 & 32 & 20 & 18 & ns & ns & $\mathrm{ns}$ & ns & ns \\
\hline
\end{tabular}


Table 52. Fort Drum Airport site 2-year percent cover and bare ground on 29 June 2004.

\begin{tabular}{|c|c|c|c|c|c|c|c|c|c|}
\hline & Treatment & WL & $\mathrm{FF}$ & SG & $H G$ & $\begin{array}{c}\text { Total } \\
\text { sown } \\
\text { species }\end{array}$ & $\begin{array}{l}\text { Other } \\
\text { species }\end{array}$ & Dead WL & $\begin{array}{l}\text { Bare } \\
\text { ground }\end{array}$ \\
\hline 1 & $\begin{array}{l}\text { Weeping } \\
\text { lovegrass }\end{array}$ & 2 & - & - & - & 2 & 61 & 24 & 14 \\
\hline 2 & $\begin{array}{l}\text { Weeping } \\
\text { lovegrass + } \\
\text { hairgrass }\end{array}$ & 1 & - & - & 0 & 12 & 46 & 30 & 13 \\
\hline 3 & $\begin{array}{l}\text { Weeping } \\
\text { lovegrass + } \\
\text { switchgrass }\end{array}$ & 0 & - & 48 & - & 37 & 41 & 13 & 9 \\
\hline 4 & $\begin{array}{l}\text { Weeping } \\
\text { lovegrass + } \\
\text { switchgrass + } \\
\text { hairgrass }\end{array}$ & 3 & - & 39 & 0 & 42 & 28 & 16 & 13 \\
\hline 5 & $\begin{array}{l}\text { Weeping } \\
\text { lovegrass + } \\
\text { hairgrass + } \\
\text { switchgrass + } \\
\text { fine fescues }\end{array}$ & 0 & 34 & 13 & 0 & 48 & 27 & 14 & 10 \\
\hline 6 & $\begin{array}{l}\text { Weeping } \\
\text { lovegrass + } \\
\text { hairgrasses + } \\
\text { fine fescues }\end{array}$ & 0 & 26 & - & 0 & 19 & 42 & 22 & 16 \\
\hline 7 & $\begin{array}{l}\text { Weeping } \\
\text { lovegrass + } \\
\text { switchgrass + } \\
\text { fine fescues }\end{array}$ & 0 & 16 & 37 & - & 60 & 16 & 7 & 17 \\
\hline 8 & $\begin{array}{l}\text { Weeping } \\
\text { lovegrass + } \\
\text { fine fescues }\end{array}$ & 8 & 57 & - & - & 22 & 29 & 26 & 23 \\
\hline & LSD @ 0.05 & ns & 23 & 20 & ns & 25 & ns & 19 & 19 \\
\hline
\end{tabular}


Table 53. Fort Drum Airport site 3-year percent cover and bare ground on 7 September 2005.

\begin{tabular}{|c|c|c|c|c|c|c|c|c|c|}
\hline & Treatment & WL & FF & SG & HG & $\begin{array}{l}\text { Total } \\
\text { sown } \\
\text { species }\end{array}$ & $\begin{array}{l}\text { Other } \\
\text { species }\end{array}$ & $\begin{array}{l}\text { Dead } \\
\text { WL }\end{array}$ & $\begin{array}{l}\text { Bare } \\
\text { ground }\end{array}$ \\
\hline 1 & Weeping lovegrass & 8 & - & - & - & 8 & 22 & 14 & 56 \\
\hline 2 & $\begin{array}{l}\text { Weeping lovegrass + } \\
\text { hairgrass }\end{array}$ & 0 & - & - & 0 & 0 & 25 & 48 & 27 \\
\hline 3 & $\begin{array}{l}\text { Weeping lovegrass + } \\
\text { switchgrass }\end{array}$ & 1 & - & 46 & - & 48 & 5 & 1 & 46 \\
\hline 4 & $\begin{array}{l}\text { Weeping lovegrass + } \\
\text { switchgrass + hairgrass }\end{array}$ & 0 & - & 50 & 0 & 51 & 6 & 2 & 40 \\
\hline 5 & $\begin{array}{l}\text { Weeping lovegrass + } \\
\text { hairgrass + switchgrass } \\
+ \text { fine fescues }\end{array}$ & 0 & 31 & 17 & 0 & 48 & 6 & 7 & 39 \\
\hline 6 & $\begin{array}{l}\text { Weeping lovegrass + } \\
\text { hairgrasses + } \\
\text { fine fescues }\end{array}$ & 1 & 33 & - & 0 & 33 & 26 & 1 & 40 \\
\hline 7 & $\begin{array}{l}\text { Weeping lovegrass + } \\
\text { switchgrass }+ \\
\text { fine fescues }\end{array}$ & 0 & 44 & 31 & - & 76 & 0 & 4 & 21 \\
\hline 8 & $\begin{array}{l}\text { Weeping lovegrass + } \\
\text { fine fescues }\end{array}$ & 0 & 65 & - & - & 65 & 1 & 3 & 32 \\
\hline & LSD @ 0.05 & ns & 16 & 16 & ns & 19 & ns & 11 & ns \\
\hline
\end{tabular}


Table 54. Fort Drum Airport site 4-year percent cover and bare ground on 7 June 2006.

\begin{tabular}{|c|c|c|c|c|c|c|c|c|c|}
\hline & Treatment & WL & $\mathrm{FF}$ & SG & $H G$ & $\begin{array}{l}\text { Total } \\
\text { sown } \\
\text { species }\end{array}$ & $\begin{array}{c}\text { Other } \\
\text { species }\end{array}$ & $\begin{array}{c}\text { Dead } \\
\text { (mostly } \\
\text { WL) }\end{array}$ & $\begin{array}{l}\text { Bare } \\
\text { ground }\end{array}$ \\
\hline 1 & $\begin{array}{l}\text { Weeping } \\
\text { lovegrass }\end{array}$ & 0 & -- & -- & -- & 0 & 28 & 18 & 54 \\
\hline 2 & $\begin{array}{l}\text { Weeping } \\
\text { lovegrass + } \\
\text { hairgrass }\end{array}$ & 0 & -- & -- & 0 & 0 & 78 & 7 & 15 \\
\hline 3 & $\begin{array}{l}\text { Weeping } \\
\text { lovegrass + } \\
\text { switchgrass }\end{array}$ & 0 & -- & 64 & -- & 64 & 7 & 6 & 24 \\
\hline 4 & $\begin{array}{l}\text { Weeping } \\
\text { lovegrass + } \\
\text { switchgrass + } \\
\text { hairgrass }\end{array}$ & 0 & -- & 52 & 0 & 52 & 3 & 24 & 21 \\
\hline 5 & $\begin{array}{l}\text { Weeping } \\
\text { lovegrass + } \\
\text { hairgrass + } \\
\text { switchgrass + } \\
\text { fine fescues }\end{array}$ & 0 & 38 & 0 & 0 & 38 & 24 & 3 & 34 \\
\hline 6 & $\begin{array}{l}\text { Weeping } \\
\text { lovegrass + } \\
\text { hairgrasses + } \\
\text { fine fescues }\end{array}$ & 0 & 39 & -- & 0 & 39 & 24 & 2 & 34 \\
\hline 7 & $\begin{array}{l}\text { Weeping } \\
\text { lovegrass + } \\
\text { switchgrass + } \\
\text { fine fescues }\end{array}$ & 0 & 33 & 24 & -- & 57 & 0 & 3 & 33 \\
\hline \multirow[t]{2}{*}{8} & $\begin{array}{l}\text { Weeping } \\
\text { lovegrass + } \\
\text { fine fescues }\end{array}$ & 0 & 43 & -- & -- & 43 & 6 & 0 & 51 \\
\hline & LSD @ 0.05 & ns & ns & 8 & ns & 16 & 21 & 14 & 18 \\
\hline
\end{tabular}

\section{D.8 Tracking data}

The 2005 soil data by entry immediately before and after tracking are shown below (Table 55 - Table 59); summary soil data are given in Section 5.6.3.1. There were essentially no significant differences in soil data among the different plant entries. The only significant difference was between the two Snake River wheatgrass entries for shear vane measurements before tracking. 
Table 55. Soil moisture, shear vane, and cone penetrometer data immediately before and after tracking (June 2005).

\begin{tabular}{|c|c|c|c|c|c|}
\hline \multirow[b]{2}{*}{ Entry } & \multicolumn{2}{|c|}{ Before tracking } & \multicolumn{3}{|c|}{$\begin{array}{l}\text { Cone penetrometer }(\mathrm{cm}) \\
\text { (after tracking) }\end{array}$} \\
\hline & $\begin{array}{c}\text { Soil } \\
\text { moisture } \\
(\%)\end{array}$ & $\begin{array}{l}\text { Shear } \\
\text { vane } \\
(\mathrm{kPa})\end{array}$ & 0 Pass & 1 Pass & 4 Pass \\
\hline Siberian wheatgrass (Vavilov II) & 2.9 & 43.8 & 6.2 & 7.3 & 10.5 \\
\hline Siberian wheatgrass (Vavilov) & 3.0 & 38.9 & 5.5 & 7.7 & 12.1 \\
\hline Russian wildrye (Bozoisky II parent) & 2.7 & 36.2 & 6.3 & 8.2 & 11.4 \\
\hline Russian wildrye (BozXTet) & 3.0 & 39.2 & 6.1 & 7.0 & 11.6 \\
\hline Crested wheatgrass (Roadcrest) & 2.8 & 37.9 & 6.7 & 6.8 & 10.5 \\
\hline Basin wheatgrass (Trailhead) & 2.9 & 41.5 & 6.5 & 7.9 & 12.6 \\
\hline Mix-1-Introduced & 2.8 & 45.2 & 6.7 & 8.3 & 11.1 \\
\hline Mix-2-Native & 2.6 & 36.2 & 6.8 & 6.9 & 10.6 \\
\hline Bluebunch wheatgrass (P7) & 3.1 & 39.0 & 5.3 & 8.3 & 12.1 \\
\hline Bluebunch wheatgrass (Goldar) & 3.0 & 40.2 & 7.0 & 7.6 & 12.2 \\
\hline Sandberg wheatgrass (Reliable) & 2.8 & 34.5 & 6.3 & 7.8 & 11.7 \\
\hline $\begin{array}{l}\text { Sandberg wheatgrass (common } \\
\text { variety) }\end{array}$ & 2.7 & 36.8 & 5.4 & 8.0 & 12.0 \\
\hline Slender wheatgrass (FirstStrike) & 2.9 & 36.3 & 6.0 & 7.8 & 12.0 \\
\hline Slender wheatgrass (Pryor) & 2.7 & 35.0 & 5.9 & 8.9 & 12.6 \\
\hline $\begin{array}{l}\text { Snake River wheatgrass (SERDP } \\
\text { Select) }\end{array}$ & 2.6 & $48.7 *$ & 7.2 & 7.2 & 12.0 \\
\hline Snake River wheatgrass (Secar) & 2.8 & 34.9 & 7.2 & 9.0 & 12.2 \\
\hline Western wheatgrass (Recovery) & 2.8 & 35.7 & 5.9 & 8.2 & 11.0 \\
\hline Western wheatgrass (Rosana) & 2.6 & 38.5 & 5.9 & 7.6 & 11.9 \\
\hline Western Yarrow (Yakima) & 2.9 & 38.4 & 6.2 & 7.7 & 11.5 \\
\hline Western Yarrow (common variety) & 2.9 & 39.8 & 6.2 & 8.0 & 12.3 \\
\hline Overall mean & 2.8 & 38.8 & 6.3 & 7.8 & 11.6 \\
\hline LSD @0.05 & 0.3 & 6.5 & ns & ns & ns \\
\hline
\end{tabular}

* Significantly different than the standard cultivar entry for this species. 
Table 56. Rut depth means by entry for all years after tracking (2005-2007).

\begin{tabular}{|c|c|c|c|}
\hline \multirow[b]{2}{*}{ Entry } & \multicolumn{2}{|c|}{ Rut depth $(\mathrm{cm})$} & \multirow[b]{2}{*}{ LSD @ 0.05} \\
\hline & 1 Pass & 4 Pass & \\
\hline Siberian wheatgrass (Vavilov II) & 3.25 & 5.33 & 1.85 \\
\hline Siberian wheatgrass (Vavilov) & 4.75 & 7.23 & 0.83 \\
\hline Russian wildrye (Bozoisky II parent) & 4.25 & 6.62 & 0.49 \\
\hline Russian wildrye (BozXTet) & 4.25 & 7.29 & 1.47 \\
\hline Slender wheatgrass (FirstStrike) & 4 & 7.42 & 2.49 \\
\hline Slender wheatgrass (Pryor) & 5.75 & 8.47 & 0.86 \\
\hline Snake River wheatgrass (SERDP Select) & 4.04 & 8.92 & 1.63 \\
\hline Snake River wheatgrass (Secar) & 4.7 & 6.76 & 1.54 \\
\hline Western wheatgrass (Recovery) & 3.7 & 6.01 & 1.63 \\
\hline Western wheatgrass (Rosana) & 3.25 & 6.52 & 2.25 \\
\hline LSD @ 0.05 & 0.225 & 0.246 & \\
\hline Overall mean & 4.2 & 7 & 0.4 \\
\hline
\end{tabular}

Table 57. Percent cover of vegetation in June 2005 immediately after tracking.

\begin{tabular}{|c|c|c|c|}
\hline Entry & 0 pass & 1 pass & 4 pass \\
\hline Bluebunch wheatgrass (P-7) & 47.9 & 29.2 & 3.1 \\
\hline Bluebunch wheatgrass (Goldar) & 35.4 & 38.5 & 8.3 \\
\hline Russian wildrye (Bozoisky II) & $71.9 *$ & 57.3 & 34.4 \\
\hline Russian wildrye (BozXTet) & 33.3 & 57.3 & 17.1 \\
\hline Siberian wheatgrass (Vavilov II) & 65.6 & $66.7 *$ & $34.4 *$ \\
\hline Siberian wheatgrass (Vavilov) & 42.7 & 36.5 & 5.2 \\
\hline Slender wheatgrass (FirstStrike) & 17.7 & 8.3 & 0 \\
\hline Slender wheatgrass (Pryor) & 8.3 & 10.4 & 8.3 \\
\hline Snake River wheatgrass (SERDP) & $76.0 *$ & 74.0 & $53.1^{*}$ \\
\hline Snake River wheatgrass (Secar) & 41.7 & 46.9 & 20.8 \\
\hline Western wheatgrass (Recovery) & 53.1 & 44.8 & 17.1 \\
\hline Western wheatgrass (Rosana) & 61.5 & 36.5 & 18.8 \\
\hline LSD @ 0.05 & 32 & 30 & 24 \\
\hline
\end{tabular}

* Significantly different than the standard cultivar entry for this species. 
Table 58. Percent cover of vegetation in June 2006, 1 year after tracking.

\begin{tabular}{|c|c|c|c|}
\hline Entry & 0 pass & 1 pass & 4 pass \\
\hline Bluebunch wheatgrass (P-7) & 57.3 & 45.3 & 8.3 \\
\hline Bluebunch wheatgrass (Goldar) & 50.0 & 49.0 & 14.6 \\
\hline Russian wildrye (Bozoisky II) & 85.4 & 71.9 & 50.0 \\
\hline Russian wildrye (BozXTet) & 63.5 & 67.7 & 42.7 \\
\hline Siberian wheatgrass (Vavilov II) & 81.3 & 84.4 & $62.5^{*}$ \\
\hline Siberian wheatgrass (Vavilov) & 66.7 & 65.6 & 20.8 \\
\hline Slender wheatgrass (FirstStrike) & 22.9 & 12.5 & 1.0 \\
\hline Slender wheatgrass (Pryor) & 19.8 & 16.7 & 9.4 \\
\hline Snake River wheatgrass (SERDP) & 82.3 & 81.3 & $59.4 *$ \\
\hline Snake River wheatgrass (Secar) & 59.4 & 53.1 & 27.1 \\
\hline Western wheatgrass (Recovery) & 69.8 & 53.1 & 18.8 \\
\hline Western wheatgrass (Rosana) & 67.7 & 46.9 & 31.3 \\
\hline LSD @ 0.05 & 34 & 32 & 23 \\
\hline
\end{tabular}

* Significantly different than the standard cultivar entry for this species.

Table 59. Percent cover of vegetation in June 2007,2 years after tracking.

\begin{tabular}{|c|c|c|c|}
\hline Entry & 0 pass & 1 pass & 4 pass \\
\hline Bluebunch wheatgrass (P-7) & 52.1 & 35.4 & 9.4 \\
\hline Bluebunch wheatgrass (Goldar) & 27.1 & 28.1 & 15.6 \\
\hline Russian wildrye (Bozoisky II) & 71.9 & $71.9 *$ & 42.7 \\
\hline Russian wildrye (BozXTet) & 59.4 & 41.7 & 46.9 \\
\hline Siberian wheatgrass (Vavilov II) & 76.0 & 75.0 & $65.6 *$ \\
\hline Siberian wheatgrass (Vavilov) & 54.2 & 56.3 & 20.8 \\
\hline Slender wheatgrass (FirstStrike) & $54.2 *$ & 16.7 & 1.4 \\
\hline Slender wheatgrass (Pryor) & 11.5 & 6.3 & 5.2 \\
\hline Snake River wheatgrass (SERDP) & 69.8 & 69.8 & 58.3 \\
\hline Snake River wheatgrass (Secar) & 49.0 & 40.6 & 38.5 \\
\hline Western wheatgrass (Recovery) & 58.3 & 45.8 & 21.9 \\
\hline Western wheatgrass (Rosana) & 55.2 & 50.0 & 40.6 \\
\hline LSD @ 0.05 & 32 & 30 & 27 \\
\hline
\end{tabular}

* Significantly different than the standard cultivar entry for this species. 


\section{D.9 Space-planted nursery data}

\section{Recovery western wheatgrass}

Table 60. Establishment year stand of 'Recovery' western wheatgrass compared with standard western wheatgrass and other rangeland grass checks at 8 locations. Stand establishment measured as seedling frequency during the first May or June following a late-fall-dormant or early-spring planting. (Waldron et al. in prep).

\begin{tabular}{|c|c|c|c|c|c|c|c|c|c|}
\hline Cultivar† & $\begin{array}{l}\text { Beaver, } \\
\text { UT }\end{array}$ & $\begin{array}{l}\text { Guernsey, } \\
\text { WY - site } 1\end{array}$ & $\begin{array}{l}\text { Guernsey, } \\
\text { WY - site } 2\end{array}$ & $\begin{array}{l}\text { Malta, } \\
\text { ID }\end{array}$ & $\begin{array}{l}\text { Fillmore, } \\
\text { UT - site } 1\end{array}$ & $\begin{array}{l}\text { Fillmore, } \\
\text { UT - site } 2\end{array}$ & $\begin{array}{l}\text { Curlew } \\
\text { Valley, } \\
\text { ID }\end{array}$ & $\begin{array}{l}\text { Yakima, } \\
\text { WA }\end{array}$ & $\begin{array}{l}\text { Across } \\
\text { loc. } \\
\text { Mean }\end{array}$ \\
\hline Recovery & 0.54 & 0.61 & 0.51 & 0.68 & 0.66 & 0.63 & 0.46 & 0.73 & 0.60 \\
\hline \multicolumn{10}{|l|}{ WWG checks } \\
\hline Arriba & $0.21 *$ & . & . & $0.41 *$ & 0.54 & 0.82 & 0.44 & . & $0.45 *$ \\
\hline Barton & $0.36 *$ & . & . & $0.55 *$ & $0.38 *$ & 0.64 & 0.37 & . & $0.42 *$ \\
\hline Flintlock & . & 0.57 & $0.22 *$ & . & . & 0.84 & . & . & $0.53 *$ \\
\hline Rodan & $0.25 *$ & . & . & $0.55 *$ & $0.48 *$ & 0.78 & 0.39 & . & $0.45^{*}$ \\
\hline Rosana & 0.51 & 0.55 & 0.39 & $0.45 *$ & $0.35 *$ & 0.73 & 0.49 & $0.40 *$ & $0.48 *$ \\
\hline SB3 & $0.40 *$ & 0.54 & 0.49 & 0.69 & $0.45 *$ & 0.88 & $0.34 *$ & . & $0.53 *$ \\
\hline \multicolumn{10}{|l|}{ Other checks } \\
\hline Bannock & 0.73 & 0.50 & 0.51 & . & . & . & . & . & 0.61 \\
\hline Bozoisky & 0.72 & 0.17 & 0.65 & 0.61 & 0.21 & 0.63 & 0.56 & . & 0.50 \\
\hline Bozoisky_II & 0.70 & 0.48 & 0.50 & 0.67 & 0.23 & . & 0.60 & 0.54 & 0.55 \\
\hline FirstStrike & 0.84 & 0.81 & 0.62 & 0.86 & 0.56 & 0.81 & . & 0.82 & 0.75 \\
\hline Hycrest & 0.86 & . & . & 0.92 & 0.65 & . & 0.56 & . & 0.74 \\
\hline Hycrest_II & 0.90 & . & . & 0.94 & 0.64 & 0.63 & 0.72 & . & 0.73 \\
\hline Vavilov & 0.82 & 0.38 & 0.65 & 0.92 & 0.54 & . & 0.40 & 0.23 & 0.58 \\
\hline Vavilov_II & 0.94 & 0.54 & 0.67 & 0.95 & 0.79 & . & 0.70 & 0.52 & 0.76 \\
\hline WWG mean & 0.38 & 0.57 & 0.40 & 0.56 & 0.48 & 0.76 & 0.41 & 0.56 & 0.50 \\
\hline Entry Mean & 0.62 & 0.52 & 0.52 & 0.71 & 0.50 & 0.74 & 0.50 & 0.54 & 0.58 \\
\hline LSD (0.05) & 0.13 & 0.23 & 0.18 & 0.12 & 0.18 & 0.18 & 0.12 & 0.17 & 0.06 \\
\hline
\end{tabular}

†Designations in this column include: WWG=western wheatgrass; SB3 is a WWG breeding population closely related to Recovery; Bannock is a thickspike wheatgrass; Bozoisky and Bozoisky II are Russian wildryes; FirstStrike is a slender wheatgrass; Hycrest and Hycrest II are crested wheatgrasses; and Vavilov and Vavilov II are Siberian wheatgrasses.

*Western wheatgrass check cultivars with stand frequency significantly $(P<0.05)$ lower than Recovery western wheatgrass. 
Table 61. Second-year stand of 'Recovery' western wheatgrass compared with standard western wheatgrass and other rangeland grass checks at eight locations. Stand establishment measured as plant frequency during the second May or June following a late-fall-dormant or early-spring planting. (Waldron et al. in prep).

\begin{tabular}{|c|c|c|c|c|c|c|c|c|c|}
\hline Cultivar† & $\begin{array}{l}\text { Beaver, } \\
\text { UT }\end{array}$ & $\begin{array}{l}\text { Guernsey, } \\
\text { WY - site } 1\end{array}$ & $\begin{array}{l}\text { Guernsey, } \\
\text { WY - site } 2\end{array}$ & $\begin{array}{l}\text { Malta, } \\
\text { ID }\end{array}$ & $\begin{array}{l}\text { Fillmore, } \\
\text { UT - site } 1\end{array}$ & $\begin{array}{l}\text { Fillmore, } \\
\text { UT - site } 2\end{array}$ & $\begin{array}{l}\text { Curlew } \\
\text { Valley, } \\
\text { ID }\end{array}$ & $\begin{array}{l}\text { Yakima, } \\
\text { WA }\end{array}$ & $\begin{array}{l}\text { Across } \\
\text { loc. } \\
\text { mean }\end{array}$ \\
\hline Recovery & 0.84 & 0.73 & 0.74 & 0.73 & 0.91 & 0.74 & 0.60 & 0.81 & 0.77 \\
\hline \multicolumn{10}{|l|}{ WWG checks } \\
\hline Arriba & $0.63 *$ & . & . & $0.32 *$ & 0.86 & 0.88 & 0.59 & . & $0.63 *$ \\
\hline Barton & 0.72 & . & . & $0.55 *$ & 0.85 & 0.84 & 0.57 & . & $0.68 *$ \\
\hline Flintlock & . & 0.50 & 0.71 & . & . & 0.83 & . & . & $0.66 *$ \\
\hline Rodan & $0.59 *$ & . & . & $0.49 *$ & 0.87 & 0.84 & 0.61 & . & $0.66 *$ \\
\hline Rosana & 0.81 & 0.77 & 0.78 & $0.32 *$ & $0.72 *$ & 0.90 & 0.61 & 0.53 & $0.68 *$ \\
\hline SB3 & $0.67 *$ & $0.46^{*}$ & 0.76 & 0.66 & $0.72 *$ & 0.89 & 0.56 & . & $0.67 *$ \\
\hline \multicolumn{10}{|l|}{ Other checks } \\
\hline Bannock & 0.85 & 0.58 & 0.81 & . & . & . & . & . & 0.73 \\
\hline Bozoisky & 0.88 & 0.26 & 0.82 & 0.57 & 0.42 & 0.72 & 0.70 & . & 0.61 \\
\hline Bozoisky_II & 0.87 & 0.61 & 0.81 & 0.79 & 0.42 & . & 0.64 & 0.67 & 0.70 \\
\hline FirstStrike & 0.94 & 0.65 & 0.89 & 0.38 & 0.83 & 0.90 & . & 0.74 & 0.75 \\
\hline Hycrest & 0.91 & . & . & 0.93 & 0.88 & . & 0.77 & . & 0.87 \\
\hline Hycrest_II & 0.91 & . & . & 0.97 & 0.86 & 0.65 & 0.82 & . & 0.82 \\
\hline Vavilov & 0.92 & 0.63 & 0.77 & 0.91 & 0.71 & . & 0.54 & 0.36 & 0.71 \\
\hline Vavilov_II & 0.99 & 0.68 & 0.91 & 1.00 & 0.88 & . & 0.62 & 0.63 & 0.83 \\
\hline WWG mean & 0.71 & 0.62 & 0.75 & 0.51 & 0.82 & 0.85 & 0.59 & 0.67 & 0.68 \\
\hline Entry Mean & 0.82 & 0.59 & 0.80 & 0.66 & 0.76 & 0.82 & 0.64 & 0.62 & 0.72 \\
\hline LSD (0.05) & 0.17 & 0.25 & 0.14 & 0.18 & 0.16 & 0.17 & 0.19 & 0.32 & 0.06 \\
\hline
\end{tabular}

†Designations in this column include: WWG=western wheatgrass; SB3 is a WWG breeding population closely related to Recovery; Bannock is a thickspike wheatgrass; Bozoisky and Bozoisky II are Russian wildryes; FirstStrike is a slender wheatgrass; Hycrest and Hycrest II are crested wheatgrasses; and Vavilov and Vavilov II are Siberian wheatgrasses.

*Western wheatgrass check cultivars with stand frequency significantly $(P<0.05)$ lower than Recovery western wheatgrass. 
Table 62. Dry matter yield (DMY) of 'Recovery' western wheatgrass compared with standard western wheatgrass and other rangeland grass checks at three locations. Yield at Nephi and Blue

Creek, UT evaluated just prior to anthesis in 2008 from 10-spaced-plant plots established in 2005. Yield from Curlew Valley, ID determined in 2006 just prior to anthesis using $1-\mathrm{m}^{2}$ clipped subsamples of plots established in 2002. (Waldron et al. in prep).

\begin{tabular}{|c|c|c|c|}
\hline \multirow[b]{2}{*}{ Cultivar } & \multicolumn{2}{|c|}{ kg/10-plants } & \multirow{2}{*}{$\begin{array}{c}\mathrm{g} / \mathrm{m}^{2} \\
\text { Curlew Valley, ID }\end{array}$} \\
\hline & Nephi, UT & Blue Creek, UT & \\
\hline Recovery & 2.0 & 2.7 & 262 \\
\hline \multicolumn{4}{|l|}{ WWG checks } \\
\hline Arriba & 2.6 & 2.7 & 360 \\
\hline Barton & $2.9 * *$ & 3.1 & 285 \\
\hline Flintlock & $3.3 * *$ & 3.0 & \\
\hline Rodan & $3.0 * *$ & 3.1 & 341 \\
\hline Rosana & $2.9 * *$ & 2.4 & $160 *$ \\
\hline SB3 & 2.5 & 2.2 & 276 \\
\hline \multicolumn{4}{|l|}{ Other checks } \\
\hline Bozoisky & 2.3 & 2.1 & 330 \\
\hline Bozoisky_II & 2.4 & 2.1 & 333 \\
\hline FirstStrike & 1.3 & 1.4 & . \\
\hline Hycrest & 2.7 & 2.9 & 373 \\
\hline Hycrest_II & 2.0 & 1.8 & 311 \\
\hline Vavilov & 2.6 & 2.4 & 373 \\
\hline Vavilov_II & 3.4 & 2.4 & 291 \\
\hline LSD (0.05) & 0.7 & 0.9 & 100 \\
\hline
\end{tabular}

†Designations in this column include: WWG=western wheatgrass; SB3 is a WWG breeding population closely related to Recovery; Bozoisky and Bozoisky II are Russian wildryes; FirstStrike is a slender wheatgrass; Hycrest and Hycrest II are crested wheatgrasses; and Vavilov and Vavilov II are Siberian wheatgrasses.

*Western wheatgrass check cultivars with DMY significantly $(P<0.05)$ lower than Recovery western wheatgrass.

**Western wheatgrass check cultivars with DMY significantly $(\mathrm{P}<0.05)$ higher than Recovery western wheatgrass. 


\section{Vavilov II Siberian wheatgrass}

Table 63. Vavilov II Siberian wheatgrass stand establishment and persistence at Malta, Idaho, and Fillmore, Utah.

\begin{tabular}{|c|c|c|c|}
\hline \multirow[b]{2}{*}{ Entry } & \multicolumn{3}{|c|}{ (\% Stand) } \\
\hline & $\begin{array}{l}\text { Establishment } \\
\text { yr: } 2005\end{array}$ & $\begin{array}{l}\text { Persistence } \\
\text { yr 2: } 2006\end{array}$ & $\begin{array}{l}\text { Persistence } \\
\text { comb: 05-06 }\end{array}$ \\
\hline \multicolumn{4}{|c|}{ Malta, Idaho (established fall 2004) } \\
\hline Vavilov Siberian wheatgrass & 92 & 91 & 91 \\
\hline Vavilov II Siberian wheatgrass & 95 & 100 & 97 \\
\hline LSD (0.05) & 5 & 6 & 6 \\
\hline \multicolumn{4}{|c|}{ Fillmore, Utah (established fall 2004) } \\
\hline Vavilov Siberian wheatgrass & 54 & 71 & 62 \\
\hline Vavilov II Siberian wheatgrass & 79 & 88 & 84 \\
\hline LSD (0.05) & 17 & 12 & 21 \\
\hline
\end{tabular}

* $(\mathrm{P}<0.05)$ Significantly better than the cultivar Vavilov Siberian wheatgrass.

Table 64. Vavilov II Siberian wheatgrass establishment and persistence at YTC (established fall 2002).

\begin{tabular}{|l|c|c|c|c|}
\hline \multirow{2}{*}{ Entry } & \multicolumn{4}{|c|}{ (\% Stand) } \\
\cline { 2 - 5 } & $\begin{array}{l}\text { Establishment } \\
\text { yr: } 2003\end{array}$ & $\begin{array}{l}\text { Persistence } \\
\text { yr 2: 2004 }\end{array}$ & $\begin{array}{l}\text { Persistence } \\
\text { yr 3: 2005 }\end{array}$ & $\begin{array}{l}\text { Persistence } \\
\text { comb: 04-05 }\end{array}$ \\
\hline Vavilov Siberian wheatgrass & 23 & 36 & 52 & 44 \\
\hline Vavilov II Siberian wheatgrass & 52 & 63 & 72 & 68 \\
\hline LSD (0.05) & 16 & 27 & 19 & 22 \\
\hline
\end{tabular}

* $(P<0.05)$ Significantly better than the cultivar Vavilov Siberian wheatgrass.

Table 65. Vavilov II Siberian wheatgrass stand establishment and persistence at Curlew Valley, Idaho (established fall 2002).

\begin{tabular}{|l|r|r|r|r|r|}
\hline \multirow{2}{*}{ Entry } & \multicolumn{6}{|c|}{ (\% Stand) } \\
\cline { 2 - 7 } & $\begin{array}{l}\text { Establish. } \\
\text { yr: } 2003\end{array}$ & $\begin{array}{l}\text { Persistence } \\
\text { yr 2: 2004 }\end{array}$ & $\begin{array}{l}\text { Persistence } \\
\text { yr 3: 2005 }\end{array}$ & $\begin{array}{l}\text { Persistence } \\
\text { yr 4: 2006 }\end{array}$ & $\begin{array}{l}\text { Persistence } \\
\text { comb: 03-06 }\end{array}$ \\
\hline Vavilov Siberian wheatgrass & 40 & 54 & 65 & 64 & 55 \\
\hline Vavilov II Siberian wheatgrass & 70 & 62 & 77 & 69 & 69 \\
\hline LSD (0.05) & 12 & 17 & 14 & 16 & 9 \\
\hline
\end{tabular}

* $(\mathrm{P}<0.05)$ Significantly better than the cultivar Vavilov Siberian wheatgrass. 
Table 66. Vavilov II Siberian wheatgrass establishment and persistence at Camp Guernsey.

\begin{tabular}{|l|r|l|l|r|}
\hline \multirow{2}{*}{ Entry } & \multicolumn{3}{|c|}{ River site } & \multicolumn{1}{|c|}{ Tower site } \\
\cline { 2 - 6 } & $\begin{array}{l}\text { Establishment } \\
\text { yr: 2004 } \\
\text { (\% stand) }\end{array}$ & $\begin{array}{l}\text { Persistence } \\
\text { Yr-2: 2005 } \\
\text { (\% stand) }\end{array}$ & $\begin{array}{l}\text { Persistence } \\
\text { comb: 04-05 } \\
\text { (\% stand) }\end{array}$ & $\begin{array}{l}\text { Establishment } \\
\text { yr: 2005 } \\
\text { (\% stand) }\end{array}$ \\
\hline Vavilov Siberian wheatgrass & 38 & 63 & 50 & 65 \\
\hline Vavilov II Siberian wheatgrass & 54 & 68 & 61 & 67 \\
\hline LSD (0.05) & 20 & 25 & 19 & 22 \\
\hline
\end{tabular}

Table 67. Vavilov II Siberian wheatgrass dry matter yield at YTC and Camp Guernsey in 2005.

\begin{tabular}{|l|r|r|r|}
\hline \multirow{2}{*}{ Entry } & \multicolumn{3}{|c|}{ DM yield $¥$ (g) } \\
\cline { 2 - 4 } & Guernsey, WY & Yakima, WA & \multicolumn{1}{l|}{ Comb. loc. } \\
\hline Vavilov Siberian WG & 52 & 29 & 39 \\
\hline Vavilov II Siberian WG & 79 & 33 & 53 \\
\hline LSD (0.05) & 18 & 9 & 11 \\
\hline
\end{tabular}

* $(\mathrm{P}<0.05)$ Significantly better than the cultivar Vavilov Siberian wheatgrass.

‡DM yield (64 × $38 \mathrm{~cm}$ plot - average of three plots)

\section{Bozoisky II Russian wildrye}

Table 68. Bozoisky II Russian wildrye percent stand establishment in 2001 in Northern Area Plains Regional Trials (NPA) established fall 1999 (Jensen et al. 2006).

\begin{tabular}{|c|c|c|c|c|c|c|c|}
\hline \multirow[b]{2}{*}{ Entry } & \multicolumn{7}{|c|}{$\%$ Stand } \\
\hline & Blue Creek, UT & Green Canyon, UT & Mead, NE & Mandan, ND & Miles City, MT & Sidney, NE & $\begin{array}{l}\text { Combined } \\
\text { locations }\end{array}$ \\
\hline \multicolumn{8}{|l|}{ Diploids } \\
\hline Bozoisky-II & 55 & 60 & 98 & 85 & 79 & 72 & 76 \\
\hline Bozoisky-Select & 41 & 42 & 99 & 79 & 75 & 71 & 69 \\
\hline Mankota & 46 & 51 & 100 & 84 & 93 & 80 & 76 \\
\hline \multicolumn{8}{|l|}{ Tetraploids } \\
\hline Tetracan & 59 & 65 & 77 & $65 *$ & 89 & 73 & 71 \\
\hline Tetra-1 RWR & 58 & 57 & 99 & 78 & 97 & 68 & 76 \\
\hline BozXTet & 71 & 62 & 100 & $67 *$ & 97 & 80 & 79 \\
\hline LSD (0.05) & 17 & 19 & $\mathrm{~ns}$ & 18 & 17 & 24 & 13 \\
\hline Test Mean & 56 & 68 & 96 & 76 & 80 & 73 & 75 \\
\hline Test High & 78 & 100 & 100 & 99 & 97 & 100 & 95 \\
\hline Test Low & 8 & 32 & 62 & 39 & 48 & 28 & 21 \\
\hline No. Entries & 91 & 91 & 86 & 88 & 88 & 82 & 98 \\
\hline
\end{tabular}

* Entries significantly less than Bozoisky-II $(P<0.05)$ 
Table 69. Bozoisky II Russian wildrye percent stand establishment at three additional sites (Jensen et al. 2006).

\begin{tabular}{|c|c|c|c|}
\hline Entry & $\begin{array}{c}\text { Gurnsey, WY } \\
\text { (est. 3/04) } \\
2004\end{array}$ & \begin{tabular}{|c|} 
Curlew Valley, ID \\
(est. 11/02) \\
2003
\end{tabular} & $\begin{array}{c}\text { YTC (est. } \\
11 / 02 \text { ) } \\
2003\end{array}$ \\
\hline \multicolumn{4}{|l|}{ Diploids } \\
\hline Bozoisky-II & 48 & 60 & 54 \\
\hline Bozoisky-Select & $17 *$ & 56 & - \\
\hline Mankota & - & - & - \\
\hline Swift & - & - & 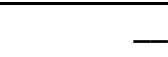 \\
\hline \multicolumn{4}{|l|}{ Tetraploids } \\
\hline BozXTet & 59 & $45 *$ & 47 \\
\hline Tetra-1 & - & - & - \\
\hline Tetracan & - & & \\
\hline LSD (0.05) & 19 & 12 & 16 \\
\hline Test Mean & 37 & 55 & 36 \\
\hline Test Min. & 0 & 34 & 4 \\
\hline Test Max & 81 & 81 & 82 \\
\hline No. of Entries & 34 & 23 & 20 \\
\hline
\end{tabular}

* Significantly less than Bozoisky-II $(P<0.05)$

Table 70. Bozoisky II Russian wildrye persistence as measured by percent stand in 2003 at four NPA sites, established 1999 (Jensen et al. 2006).

\begin{tabular}{|l|r|r|r|r|r|}
\hline & \multicolumn{5}{|c|}{ \% Stand } \\
\cline { 2 - 6 } Entry & Mead, NE & Mandan, ND & Miles City, MT & Sidney, NE & $\begin{array}{l}\text { Combined } \\
\text { locations }\end{array}$ \\
\hline Diploids & & & & & \\
\hline Bozoisky-II & 100 & 93 & 70 & 74 & 85 \\
\hline Bozoisky-Select & 98 & 87 & 75 & 83 & 86 \\
\hline Mankota & 100 & 93 & 81 & 78 & 88 \\
\hline Tetraploids & & & & & 77 \\
\hline Tetracan & 100 & 86 & 67 & 78 & 84 \\
\hline Tetra-1 RWR & 100 & 80 & 73 & 76 & 86 \\
\hline BozXTet & 17 & 14 & 83 & 80 & 13 \\
\hline LSD (0.05) & 75 & 84 & 24 & 24 & 67 \\
\hline Test Mean & 100 & 100 & 34 & 73 & 96 \\
\hline Test High & 5 & 22 & 83 & 100 & 14 \\
\hline No. Entries & 86 & 86 & 1 & 88 & 86 \\
\hline
\end{tabular}

Significantly less than Bozoisky-II $(P<0.05)$ 
Table 71.Bozoisky II Russian wildrye dry matter forage yield at NPA trial sites (established fall 1999).

\begin{tabular}{|c|c|c|c|c|c|c|c|}
\hline \multirow[b]{3}{*}{ Cultivar } & $\begin{array}{c}\text { Blue Creek, } \\
\text { UT }\end{array}$ & $\begin{array}{c}\text { Green } \\
\text { Canyon, UT }\end{array}$ & Mead, NE & $\begin{array}{l}\text { Mandan, } \\
\text { ND }\end{array}$ & $\begin{array}{c}\text { Miles City, } \\
\text { MT }\end{array}$ & $\begin{array}{l}\text { Sidney, } \\
\text { NE }\end{array}$ & $\begin{array}{l}\text { Combined } \\
\text { locations }\end{array}$ \\
\hline & \multicolumn{7}{|c|}{$\mathrm{kg} / \mathrm{ha}$ dry matter yield } \\
\hline & 2001-03 & 2001-03 & 2001-03 & 2001-03 & 2001-03 & $2001-03$ & 2001-03 \\
\hline \multicolumn{8}{|l|}{ Diploids } \\
\hline Bozoisky-II & 402 & 1096 & 4592 & 2767 & 1818 & 3600 & 2675 \\
\hline Bozoisky-Select & 565 & 785 & 4464 & 2678 & 1818 & 3581 & 2525 \\
\hline Mankota & 392 & $526 *$ & 4339 & 2919 & 1689 & 3378 & 2434 \\
\hline \multicolumn{8}{|l|}{ Tetraploids } \\
\hline Tetracan & 369 & 837 & 3790 & $1556 *$ & 1813 & 3047 & $1920 *$ \\
\hline Tetra-1 RWR & 484 & $423 *$ & 4085 & 2199 & 1421 & $2753 *$ & $2118 *$ \\
\hline BozXTet & 574 & 820 & 4058 & $1957 *$ & 1814 & 3316 & $2268 *$ \\
\hline $\operatorname{LSD}(0.05)$ & $\mathrm{ns}$ & 504 & $\mathrm{~ns}$ & 630 & $\mathrm{~ns}$ & 683 & 315 \\
\hline Test Mean & 1006 & 1844 & 6888 & 2999 & 1382 & 2790 & 3077 \\
\hline Test High & 2400 & 5209 & 10904 & 5466 & 2317 & 3768 & 7245 \\
\hline Test Low & 13 & 423 & 2590 & 729 & 627 & 207 & 307 \\
\hline No. Entries & 91 & 91 & 86 & 88 & 88 & 82 & 98 \\
\hline
\end{tabular}

* Entries significantly less than Bozoisky-II $(\mathrm{P}<0.05)$ 


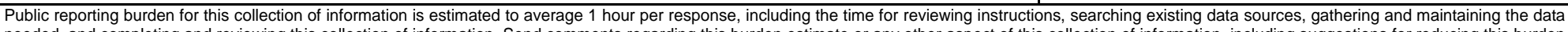

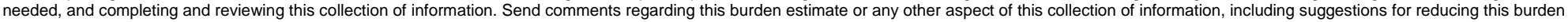

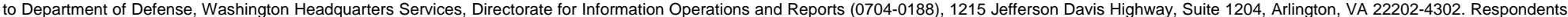

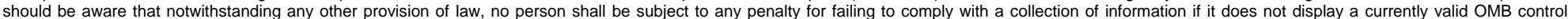
number. PLEASE DO NOT RETURN YOUR FORM TO THE ABOVE ADDRESS.
1. REPORT DATE (DD-MM- $Y Y Y Y)$
2. REPORT TYPE
December 2009
Final

\section{TITLE AND SUBTITLE}

Implementation and Commercialization of New Germplasms for Use on Military Ranges

\section{AUTHOR(S)}

Antonio J. Palazzo, Susan E. Hardy, Timothy J. Cary, Kevin Jensen, Blair Waldron, and Steven Larson

3. DATES COVERED (From - To)

5a. CONTRACT NUMBER

5b. GRANT NUMBER

5c. PROGRAM ELEMENT NUMBER

5d. PROJECT NUMBER

SI-0401

5e. TASK NUMBER

5f. WORK UNIT NUMBER

\section{PERFORMING ORGANIZATION REPORT} NUMBER

ERDC/CRREL TR-09-15

U.S. Army Engineer Research and Development Center

Cold Regions Research and Engineering Laboratory

72 Lyme Road

Hanover, NH 03755-1290

\section{SPONSORING I MONITORING AGENCY NAME(S) AND ADDRESS(ES)}

Environmental Security Technology Certification Program

901 N Stuart St, Suite 303

Arlington VA 22203

10. SPONSOR/MONITOR'S ACRONYM(S)

ESTCP

11. SPONSOR/MONITOR'S REPORT NUMBER(S)

\section{DISTRIBUTION I AVAILABILITY STATEMENT}

Approved for public release; distribution is unlimited.

\section{SUPPLEMENTARY NOTES}

\section{ABSTRACT}

Our objectives were to demonstrate and make available new plant germplasms that are more beneficial for military training lands and to develop methods to better establish native plants that are competitive with invasive introduced plants. Under Strategic Environmental Research and Development Program (SERDP) project SI-1103, we developed germplasms that establish readily, stand up to wear from military vehicles, and compete well with invasive plants but are not themselves invasive. Validation and release of the new germplasms were accomplished under both the SERDP and Environmental Security Technology Certification Program (ESTCP) programs; under ESTCP we also initiated seed contracts and prepared a planting guide (Palazzo et al. 2009). Our ten releases (including six cultivars) are summarized in notices published in Crop Science or the Journal of Plant Registrations. One additional release is expected in the next year or two. Three germplasms were put into production, and the seed was made available for two years to land managers at eight Department of Defense (DoD) facilities. A commercial sale of 'FirstStrike' slender wheatgrass has been completed. We also developed seeding methods that have proven successful on eastern and western ranges to establish viable native plant stands quickly and compete with invasive plant establishment.

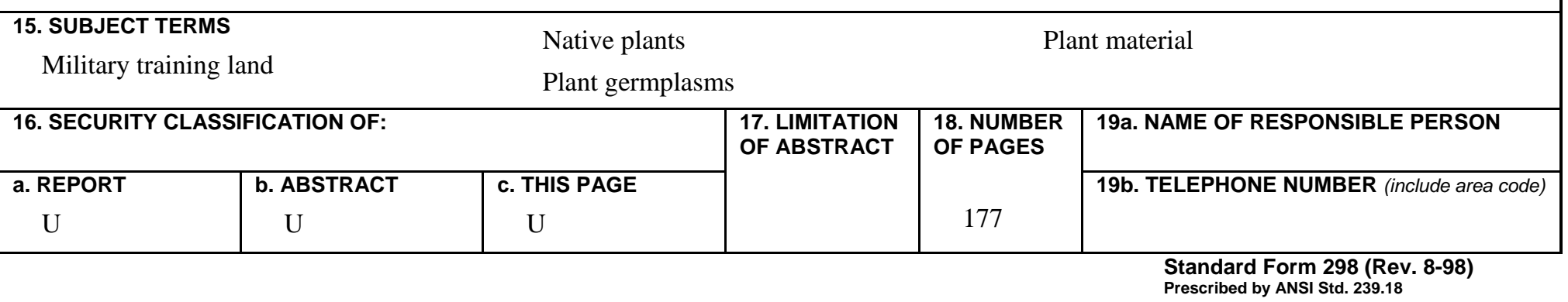

